\author{
UNIVERSIDADE DE SÃO PAULO \\ FACULDADE DE FILOSOFIA, LETRAS E CIÊNCIAS HUMANAS \\ DEPARTAMENTO DE HISTÓRIA \\ PROGRAMA DE PÓS-GRADUAÇÃO EM HISTÓRIA SOCIAL
}

\title{
O PROCESSO DE PRODUÇÃO EM MINISSÉRIES HISTÓRICAS: O PASSADO ROMANTIZADO
}

\author{
Maria Angela Raus
}

Dissertação de Mestrado apresentada ao Programa de Pós-Graduação em História Social, do Departamento de História da Faculdade de Filosofia, Letras e Ciências Humanas da Universidade de São Paulo, para obtenção do título de Mestre em História.

Orientadora: Profa. Dra. Raquel Glezer 


\section{UNIVERSIDADE DE SÃO PAULO}

FACULDADE DE FILOSOFIA, LETRAS E CIÊNCIAS HUMANAS DEPARTAMENTO DE HISTÓRIA

PROGRAMA DE PÓS-GRADUAÇÃO EM HISTÓRIA SOCIAL

\section{O PROCESSO DE PRODUÇÃO EM MINISSÉRIES HISTÓRICAS - O PASSADO ROMANTIZADO}

Maria Angela Raus 
A Angelo, Maria Imaculada e Vinicius 


\section{AGRADECIMENTOS}

Agradeço a colaboração das equipes do Arquivo Histórico Wanda Svevo da Fundação Bienal de São Paulo, das bibliotecas da FFLCH/USP e ECA/USP que possibilitaram o meu acesso às fontes e bibliografia deste trabalho.

A tantos amigos e colegas de faculdade, que me acompanham desde o início da minha graduação: Silvia Cristina Lambert Siriani, André Oliva Teixeira Mendes, Renata Monken Gomes Siqueira, Ariane Cristina Martins, Maria Cristina Vendrametto, Virgínia de Almeida Bessa, Larissa Raeli Cestari, Danilo Zione Ferreti, Ana Maria Dietrich, Júlio Suzuki, Joceley Vieira, Maria Fernanda Lopes de Almeida, Fransueldes de Abreu e Carlos Vinicius Veneziani dos Santos e muitos, muitos outros, que com muita amizade contribuíram para a minha formação.

As amigas e colaboradoras Juliana Bastos Marques, Patrícia Grillo e Fernanda Sposito.

Aos amigos e colegas de orientação e de sala: Carlos Rovaron, Thiago Nicodemo, Cris, Arnaldo Ferreira Marques, Eliane, Marisa Midori, Gisele, Marcos Capelari e Marly Spacachieri.

Agradecimentos especiais a professora Leila Hernandez, por sempre incentivar a continuidade dos trabalhos.

As professoras dos cursos de Pós-Graduação: Maria Lourdes Motter, Maria Helena Rolim Capelato, Beatriz Helena Gelas Lage.

Aos professores da banca de qualificação: Marco Antônio Guerra, meu professor também na Pós - Graduação, que contribuiu generosamente com suas idéias, e Katia Abud, professora do meu curso de Licenciatura, meu agradecimento às sugestões e referências feitas no exame.

O maior agradecimento à professora Raquel Glezer, minha orientadora, atenta a todos os detalhes de nosso trabalho e contribuindo sempre para formação de todos os seus orientandos. 
Aos professores István Jancsó e Ilana Blaj (in memorian), que me acompanharam nos anos de graduação, durante o período que participei do PET.

A Maria Adelaide Amaral, Alcides Nogueira e Renato Scarpin, todos sempre muito gentis e disponíveis a dar informações sobre seus trabalhos.

A Íris Kantor que contribuiu com o relato de sua experiência, estimulando novas idéias.

A minha família, particularmente meus pais e tios, especialmente pela colaboração material.

Aos amigos do CONSA, que nunca deixaram de estar ao meu lado e aos de tantos lugares e de tantos momentos, que sempre me apoiaram: Cris Bessa, Renata Bassetto, Susi Massoco e muitos outros.

Ao auxílio financeiro do $\mathrm{CNPq}$, sem o qual seria impossível minha dedicação a este trabalho. 


\section{Tabela de ilustrações}

Imagens de A Muralha, produzida pela TV Excelsior em 1968. ( Revista Realidade, editora Abril).............16

A autora Dinah Silveira de Queiroz (Livraria José Olympio Editora)............................................................18

Vista de Lagoa Serena na minissérie (Imagem extraída do DVD)...................................................................21

Chegada de Beatriz a São Paulo de Piratininga (Imagem extraída do DVD)...............................................p.34

Imagens do leilão de índios (Imagens extraídas do DVD).......................................................................... 37 e 38

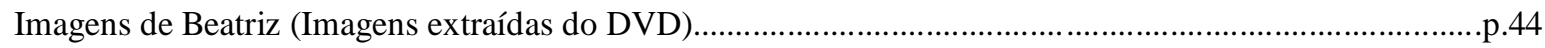

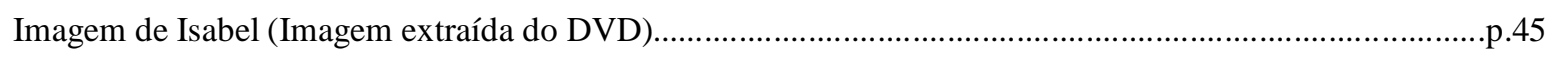

Imagem de Mãe Cândida(Imagem extraída do DVD).............................................................................p.46

Imagem de Basília (Imagem extraída do DVD).........................................................................................

Imagem de Rosália (Imagem extraída do DVD)...................................................................................

Imagem de Margarida (Imagem extraída do DVD)...............................................................................p.48

Imagens de Ana (Imagem extraída do DVD)......................................................................................... 50

Imagens de Antônia (Imagem extraída do DVD)...................................................................................... 51

Imagem de Muatira (imagem extraída do DVD) ..................................................................................p.52

Imagem de Genoveva (Imagem extraída do DVD)................................................................................ .53

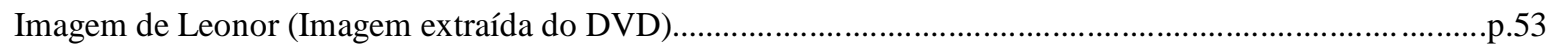

Imagens de Beatriz e Margarida no Milharal (Imagens extraídas do DVD).................................................p.62

Mulheres na atividade de fiação (Imagens extraídas do DVD).......................................................................63

Imagem de Dom Jerônimo caracterizado de Inquisidor (Imagem extraída do DVD)......................................65

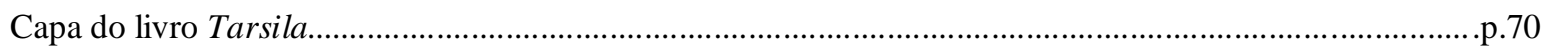

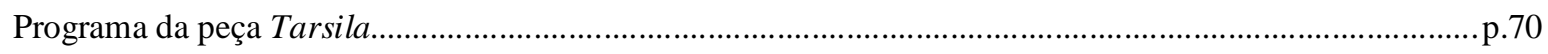

Eliane Giardini, caracterizada como Tarsila (Programa da peça Tarsila).....................................................p.70

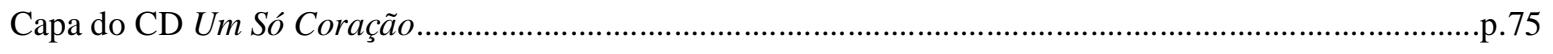

Capa do livro sobre os bastidores de Um Só Coração................................................................................... 76

Capa do livro Yolanda de Antonio Bivar.............................................................................................. 
Revista popular sobre Um Só Coração .p.80

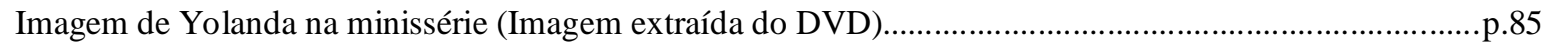

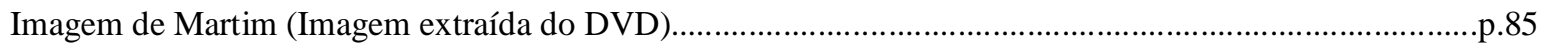

Família do coronel Totonho (Imagem extraída do DVD) ..............................................................p. 86

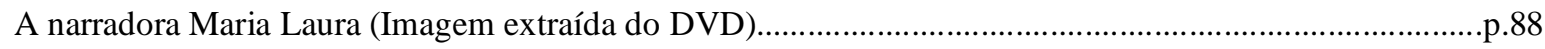

Os autores da minissérie aparecendo na minissérie (Imagem extraída do DVD)....................................p.88

Os autores da minissérie aparecendo como figurantes (Rede Globo/Editora Globo)................................p.88

Yolanda verdadeira, possivelmente em sua fazenda (Arquivo Histórico Wanda Svevo/Fundação Bienal de São

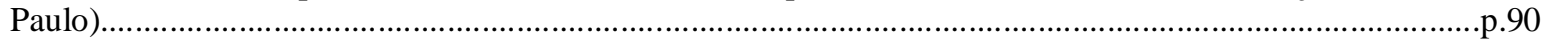

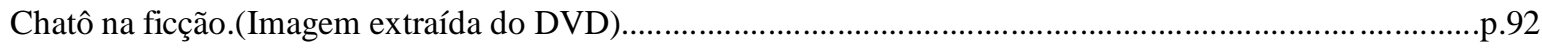

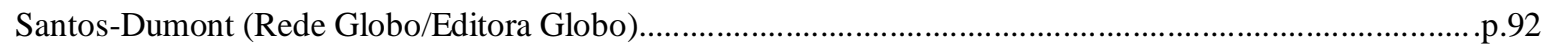

Chatô e JK na II Bienal (Arquivo Histórico Wanda Svevo/Fundação Bienal de São Paulo).......................p.92

Yolanda e Ciccillo (Arquivo Histórico Wanda Svevo/Fundação Bienal de São Paulo)..............................p.96

Ciccillo e JK (Arquivo Histórico Wanda Svevo/Fundação Bienal de São Paulo).......................................p.99

Público aguarda a abertura da II Bienal (Arquivo Histórico Wanda Svevo/Fundação Bienal de São

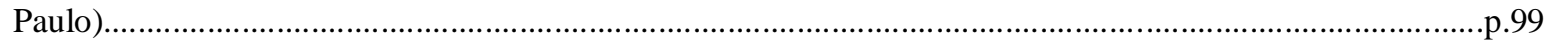

Início dos protestos pela constituição (Imagem extraída do DVD)....................................................p.100

Personagens da minissérie, partidários da causa paulista (Imagem extraída do DVD).............................p.102

Momento do enterro dos personagens símbolo da Revolução (Imagem extraída do DVD).......................p.103

Cenas de Desfile de 9 de julho (Imagens feitas para a pesquisa)...................................................p.106 e 107

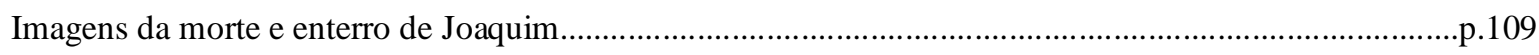




\section{RESUMO}

O trabalho que apresentamos tem como objeto de estudo a teledramaturgia baseada em acontecimentos históricos. Selecionamos como fonte duas minisséries de cunho histórico: A Muralha e Um Só Coração, produzidas pela TV Globo, e destacamos a autora Maria Adelaide Amaral. O objetivo inicial era comparar as narrativas ficcionais com o conhecimento histórico. Porém, no decorrer da pesquisa encontramos um produto cultural coletivo e industrial que se utiliza de informações históricas para construir uma narrativa ficcional particular.

As minisséries históricas foram selecionadas por tratarem a respeito de temas relativos à história da cidade de São Paulo. Ao comparar a ficção com a produção historiográfica, conseguimos identificar algumas das fontes utilizadas e as transformações realizadas.

Verificamos que as narrativas ficcionais da teledramaturgia baseadas em acontecimentos históricos se estruturam com a lógica da ficção romanesca, por integrarem a linguagem de um folhetim televisivo. As informações históricas são diluídas no pitoresco, no exótico, no diferente, mas acabam sendo assimiladas pelo público telespectador como imagens da verdade histórica.

PALAVRAS-CHAVE: história - telenovela - minisséries - São Paulo - Maria Adelaide Amaral 


\section{ABSTRACT}

This dissertation aims to study TV dramas based on historical events. The two selected works for analysis are mini-series dealing with historical narratives: A Muralha and Um Só Coração, produced by Globo Networks - Brazil, also stressing out the work of their author, Maria Adelaide Amaral. The initial goal in this study was a comparison between fictional narratives and historical knowledge. However, developing the subject allowed us to work with a collective cultural and industrial product, which uses the historical information in order to build an unique fictional narrative.

These two mini-series based on historical events were selected because they both relate to aspects of the history of São Paulo city. In comparing fiction with the historiographical studies, we were able to identify some of the sources which were used, as well as the transformations that have occurred at the mini-series.

We can see that the fictional narratives in television drama, even based in historical events, are structured according to the logic of romantic fiction. The historical information is diluted into the pitoresque, the exotic, the distinctive, but is still understood by the average viewer an image of the historical truth.

KEYWORDS: history - telenovela - mini-series - São Paulo - Maria Adelaide Amaral 


\section{SUMÁRIO}

Dedicatória

Agradecimentos

Índice de Ilustrações

Resumo

Abstract

INTRODUÇÃO. .p.1

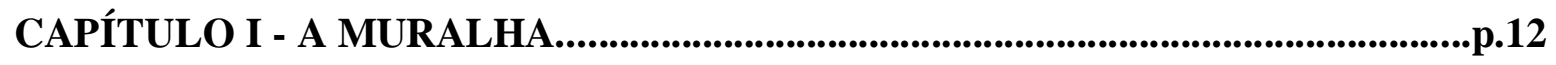

1. VERSÕES DA MESMA HISTÓRIA

2. A OBRA LITERÁRIA E SUA AUTORA

3. A MURALHA DA GLOBO

CAPÍTULO II - O PASSADO COLONIAL RECRIADO. p.33

1. O COTIDIANO: SÃO PAULO DE PIRATININGA NO SÉCULO XVII

2. A CONDIÇÃO FEMININA

3. OUTROS TEMAS

4. A HISTORIOGRAFIA TRANSFORMADA EM FONTE

CAPÍTULO III - UM SÓ CORAÇÃO. ..$p .68$

1. UM PRESENTE PARA SÃO PAULO

2. PROPAGANDA, INTERAÇÃO E REPERCUSSÃO

3. RESUMO DA MINISSÉRIE 
CAPÍTULO 4- O PASSADO REPUBLICANO RECRIADO.....................................p.89 1. UMA VIDA SE CONFUNDINDO COM A HISTÓRIA DE SÃo PAULO YOLANDA PENTEADO E O DESENVOLVIMENTO DAS ARTES

2. A REVOLUÇÃO CONSTITUCIONALISTA DE 1932 - ORGULHO DE SER PAULISTA

3. TEMAS PARA OUTROS TRABALHOS

CAPÍTULO V - OS PRODUTORES................................................................112

1. A EMPRESA GLOBO DE COMUNICAÇÃO

2. A EMISSORA DE TELEVISÃO

3. AUTOR/AUTORES

4. ATORES

5. DIRETORES

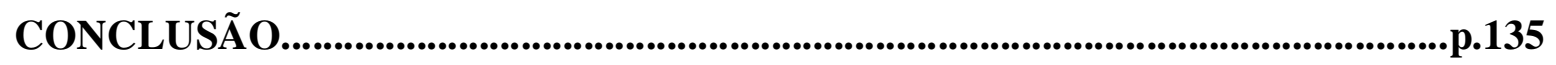

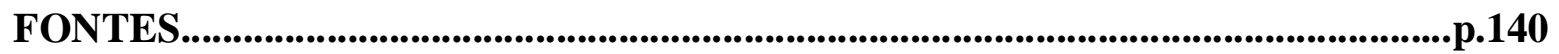

BIBLIOGRAFIA CITADA.........................................................................................p.142

ANEXOS

1. ENTREVISTAS

2. FICHAS TÉCNICAS

3. TELENOVELAS E MINISSÉRIES AMBIENTADAS EM SÃO PAULO 


\section{INTRODUÇÃO}

O trabalho que apresentamos tem o objetivo de entender, através da descrição de parcelas do processo de produção das minisséries A Muralha e Um Só Coração, qual a visão histórica construída por essas produções e a forma pela qual elas se apropriaram do conhecimento histórico, criando um outro passado no imaginário social, romantizado, de acordo com as necessidades da ficção seriada televisiva, nos formatos telenovela e minissérie, que seguem as normas do folhetim do século XIX.

Inicialmente, pretendíamos dar maior ênfase ao conhecimento histórico produzido sobre os períodos e assuntos que cada minissérie retratou. Assim, pensávamos em confrontar informações da ficção e da historiografia.

Após o exame de qualificação, realizado em novembro de 2005, quando iniciamos o processo de redação, percebemos que tal proposta oferecia dificuldades, pois trataríamos de confrontar detalhes e minúcias sem maior proveito para o conhecimento histórico. Em nada contribuiríamos para a compreensão da sociedade contemporânea e os veículos de comunicação de massa, objetos de nosso interesse nos estudos culturais.

Ao confrontar detalhes, estaríamos destacando aspectos que a ficção, em particular a ficção televisiva, não considera importante. Como nosso objetivo é a compreensão da sociedade contemporânea através da análise dos veículos de comunicação de massa, especialmente a ficção televisiva, reformulamos a proposta e estruturamos o trabalho que ora apresentamos, centrado na teledramaturgia.

A partir daí, empreendemos esforços para ampliar dados sobre o processo de produção das minisséries, no qual encontramos informações sobre os agentes de produção, objetivos de se produzir uma história inédita, ou remake, informações sobre versões anteriores, obras literárias e outras referências e fontes de inspiração, estratégias de divulgação, comercialização de produtos derivados da minissérie, repercussão, entre outras.

Com isso, não deixamos de lado o conhecimento histórico, pois entendemos a história da produção como uma história a ser considerada e que influi no conteúdo e a cidade de São Paulo, que seria objeto central, divide espaço com a nova proposta. 
Há autores que consideram a produção televisiva brasileira como exemplar, para a criação da comunidade e da identidade nacional. No início do século XX tal papel foi atribuído ao rádio. A partir dos anos sessenta, a televisão passou a exercer este papel. As produções foram sendo paulatinamente nacionalizadas até se tornarem originais e referências internacionais.

A literatura nacional foi e é fonte relevante para a produção de telenovelas e minisséries.

A teledramaturgia nacional apresenta também produções de novelas históricas ou de época, que são inspiradas em fatos e acontecimentos da história do Brasil, ou ambientadas em um período do passado. Dentre elas, muitas obtêm boas audiências, de acordo com suas emissoras.

As produções históricas são uma forma segura para atrair a audiência. Nos últimos anos, a Rede Globo, emissora que é a líder de audiência no país e a principal produtora de teledramaturgia, está sofrendo a concorrência de outras emissoras de TV aberta que estão investindo em produções de novelas. Esse investimento inicial de outras emissoras tem sido em tramas com temáticas históricas, ambientadas no passado ou inspiradas na literatura.

A Rede Globo, além do horário "das seis", apresenta anualmente uma minissérie inspirada na história, normalmente após as 22h. Desde 2000, a autora de maior destaque no horário é a dramaturga Maria Adelaide Amaral.

Nos último cinco anos Maria Adelaide assinou a autoria de quatro minisséries. A primeira foi A Muralha (2000), idealizada como parte das comemorações dos 500 anos do Descobrimento do Brasil e inspirada no romance de Dinah Silveira de Queiroz, que retrata vida de uma família de bandeirantes. A produção seguinte foi Os Maias (2001), inspirada no romance homônimo de Eça de Queiroz que retrata a decadência da aristocracia portuguesa na segunda metade do século XIX. Em 2003, escreveu A Casa das Sete Mulheres, adaptação livre do romance homônimo da escritora gaúcha Leticia Wierchowski, com co-autoria de Walter Negrão e alcançou altos índices de audiência. Narrava a trajetória real e de personagens de ficção durante a Revolução Farroupilha (1835-1845), através da ótica das mulheres da família de Bento Gonçalves. ${ }^{1}$

\footnotetext{
${ }^{1}$ Dicionário da TV Globo, v.1: programas de dramaturgia \& entretenimento (Projeto Memória das Organizações Globo). Rio de Janeiro: Jorge Zahar Ed., 2003, p.377-378.
} 
Um Só Coração (2004) foi produzida como uma homenagem da emissora ao aniversário de 450 anos da fundação da cidade de São Paulo. Contava a história da cidade entre 1922 e 1954, dando especial ênfase à cultura do período. Foi a primeira parceria de Maria Adelaide com o autor Alcides Nogueira, repetida em $J K$ (2006), que contou a história do ex-presidente do Brasil, Juscelino Kubitschek.

Maria Adelaide tem uma reconhecida carreira como autora de teatro, mas foi na televisão e através das minisséries que alcançou popularidade, sendo considerada especialista em ficções históricas para este formato.

Ambas as minisséries, escolhidas para esta pesquisa, foram ambientadas na cidade de São Paulo. Apesar de haver um grande número de novelas ambientadas no Rio de Janeiro, São Paulo, quer a cidade ou o Estado, recorrentemente, aparece na teledramaturgia, ocupando um espaço privilegiado na narrativa televisiva.

Recentemente, na Rede Globo, apareceu em Sinhá Moça, ambientada no final do século XIX, período de luta pela abolição e pela república, na fictícia cidade de Araruna, supostamente localizada no interior da província de São Paulo. A personagem principal, filha de um barão do café era abolicionista, apaixonava-se por um advogado com os mesmos ideais, que estudou no Largo São Francisco. O original é de autoria de Benedito Ruy Barbosa, autor que costuma explorar São Paulo e sua história. Uma das produções mais relevantes de Benedito foi Os Imigrantes (1981/1982), produzida e exibida pela Rede Bandeirantes, sobre os grupos que ajudaram a construir o Brasil no século XX. A história teve três fases e se estendeu por mais de um ano. ${ }^{2}$

Outra produção recente foi Belíssima (2006), novela de Sílvio de Abreu, que ambientou sua narrativa no contemporâneo da cidade, com locais e tipos populares (como descendentes de imigrantes) e personagens ricas (caracterizadas como executivos de grandes empresas que circulam nos centros empresariais e locais sofisticados da cidade). Na produção deste autor, a cidade de São Paulo contemporânea é uma fonte de inspiração.

A Globo também está reprisando Chocolate com Pimenta, produção de 2003/2004, que fez grande sucesso no horário "das seis”. Seu autor Walcyr Carrasco, além de fazer novelas de época, costuma apresentar São Paulo em suas obras: Fascinação (1998), no SBT, O Cravo e a Rosa (2000/2001), A Padroeira (2001/2002) e Alma Gêmea

\footnotetext{
${ }^{2}$ Ismael Fernandes. Memória da telenovela brasileira. 4a ed. ampl. São Paulo: Brasiliense, 1997, p.246-247.
} 
(2005/2006), na Globo. A curiosidade sobre este autor é que cursou três anos de História na Universidade de São Paulo. ${ }^{3}$

A fictícia cidade de Guará, no interior de São Paulo, foi o cenário de Cidadão Brasileiro, novela de Lauro César Muniz, produzida e exibida na Rede Record, em 2006. Lauro também é um autor que usa São Paulo periodicamente. Exemplo disso foi o seu primeiro trabalho original, Os Deuses Estão Mortos, também na Record. Era uma novela histórica, passada no final do século XIX e abordava temas como a crise na sociedade brasileira após a abolição da escravatura e a iminência da república. ${ }^{4}$

Como podemos observar, alguns temas são repetidos por diversos autores que utilizam a história de São Paulo em suas tramas. Entre os exemplos apontados está a luta pela abolição e a república, temas que acabam levando a tratar da importância do café na economia paulista e este como fator de desenvolvimento do país.

Outros temas utilizados por diversos autores são: imigração, decadência do café, industrialização, entre vários outros. Observamos que um tema histórico está dentro de um contexto que permite a ampliação e abordagem de outros. Por exemplo, ao falar de indústria, trata-se do operariado, pois o tratamento de um tema histórico, mesmo que seja na ficção, exige a contextualização, que serve de elemento para criação de conflitos e do cotidiano das personagens.

Maria Adelaide Amaral é uma autora que freqüentemente explora São Paulo em suas obras.

Em relação às minisséries históricas, a primeira minissérie transmitida pela Rede Globo foi Lampião e Maria Bonita (1982), com 8 capítulos. A emissora produziu aproximadamente 56 minisséries. ${ }^{5}$ Algumas dessas minisséries possuíram temáticas contemporâneas à época que foram produzidas, mas a maioria costuma ser inspirada em literatura brasileira, peças de teatro e acontecimentos históricos.

\footnotetext{
3 Janaína Nunes \& Rosana Aubin. Abaixo as fórmulas. Diário de S. Paulo, 04/09/2005, c. Já TV, ano 9, no 461, p.8-14.

${ }^{4}$ As informações apresentadas sobre a produção de teledramaturgia e seus autores, que utilizam São Paulo como tema e/ou ambientação, são referentes ao atual momento da televisão e produção deste texto. Não podemos deixar de mencionar que outros autores, já falecidos, também usaram a cidade, seja na perspectiva histórica, ou contemporânea a sua produção. São exemplos: Jorge de Andrade e Cassiano Gabus Mendes.
} 
Entre as minisséries inspiradas na literatura, em sua maioria brasileira, encontramos: Anarquistas Graças a Deus (1984); Rabo de Saia (1984); O Tempo e o Vento (1985); Tenda dos Milagres (1985); Grande Sertão Veredas (1985); Memórias de um Gigolô (1986); O Primo Basílio (1988); Riacho Doce (1990); O Sorriso do Lagarto (1991); Tereza Batista (1992); Agosto (1993); A Madona de Cedro (1994); Memorial de Maria Moura (1994); Incidente em Antares (1994); Dona Flor e seus Dois Maridos (1998); Hilda Furacão (1998); Luna Caliente (1999); A Muralha (2000); Os Mais (2001); Presença de Anita (2001); Pastores da Noite (2002), A Casa das Sete Mulheres (2003) e Mad Maria (2005). ${ }^{6}$ Muitas delas acabam aliando a literatura e a história, pois são romances de época ou históricos. Também destaca-se a produção de textos originais com temática histórica, por exemplo: Anos Dourados (1986); Abolição (1988); República (1989); Anos Rebeldes (1992) e Aquarela do Brasil (2000). Também há textos inspirados em biografias como: Desejo (1990) e Chiquinha Gonzaga (1999).

Houve produções que usaram da comédia para contar a história do Brasil: A Invenção do Brasil (2000) e O Quinto dos Infernos (2002).

Atualmente a Globo prepara uma minissérie para estrear em 2007 sobre a história do Acre, com autoria de Glória Perez.

A produção televisiva nacional tem sido objeto de múltiplos estudos, no país e no exterior, nos campos especializados da Comunicação Social e da Antropologia.

Existem alguns trabalhos acadêmicos sobre televisão e teledramaturgia, a partir do trabalho pioneiro de Sérgio Miceli, de 1971, A Noite da Madrinha: ensaio sobre a indústria cultural no Brasil. ${ }^{7}$ No mesmo ano, Solange Martins Couceiro apresentou Negro na televisão de São Paulo: estudo de relações raciais ${ }^{8}$. Dos anos setenta até a atualidade, o interesse pela televisão e sua produção tem crescido. No que diz respeito à telenovela,

\footnotetext{
${ }^{5}$ Dicionário da TV Globo, v.1: programas de dramaturgia \& entretenimento (Projeto Memória das Organizações Globo). Rio de Janeiro: Jorge Zahar Ed., 2003. p.307-378. Contagem até a produção deste texto.

${ }^{6}$ As minisséries O Primo Basílio (1988) e Os Maias (2001) foram inspiradas em obras da literatura portuguesa, do escritor Eça de Queiroz.

${ }^{7}$ Sérgio Miceli. A Noite da Madrinha: ensaio sobre a indústria cultural no Brasil. Dissertação de Mestrado em Sociologia. São Paulo: FFLCH/USP (Departamento Ciências Sociais), 1971.

${ }^{8}$ Solange Martins Couceiro. Negro na televisão de São Paulo: estudo de relações raciais. Dissertação de Mestrado em Antropologia. São Paulo: FFLCH/USP (Departamento de Ciências Sociais), 1971.
} 
podemos citar os trabalhos de Renato Ortiz e Samira Youssef Campedelli durante os anos oitenta. ${ }^{9}$

Na Universidade de São Paulo houve a fundação de um núcleo de pesquisa dedicado aos estudos de telenovela, abrangendo trabalhos sobre qualquer tipo de ficção seriada - o Núcleo de Pesquisa de Telenovela da ECA/USP, de 1992. Muitos dos trabalhos produzidos sobre telenovela na última década foram feitos por pesquisadores ligados a este núcleo, como os das professoras Ana Maria Fadul, Maria Lourdes Motter, Maria Immacolata Vassalo de Lopes e Renata Pallottini. ${ }^{10}$

Na bibliografia internacional encontramos os trabalhos do professor Jesús MartínBarbero $^{11}$, que são referência para o estudo da telenovela latino-americana, e os de Armand e Michèle Mattelart ${ }^{12}$, além de diversos outros, especialmente em forma de artigos, hoje acessíveis graças à disponibilização pela internet.

Consideramos a teledramaturgia (em particular as novelas e minisséries) um objeto de estudo interdisciplinar, pois é dinâmico e multitemático. Definindo as especificidades do nosso objeto, a minissérie constitui um formato, dentro do gênero ficção seriada televisiva e da categoria entretenimento. ${ }^{13}$

No decorrer desta pesquisa, consideramos não só uma bibliografia sobre telenovela e televisão, como também algumas referências de trabalho sobre cinema e história, tais

\footnotetext{
${ }^{9}$ Renato Ortiz; Sílvia Helena Simões Borelli; José Mário Ortiz Ramos. Telenovela: história e produção. $2^{\mathrm{a}}$ ed. São Paulo: Brasiliense, 1991, (a primeira edição é de 1989); Samira Youssef Campedelli. A telenovela. $2^{a}$ ed. São Paulo: Ática, 1987; -. Telenovela e folhetim. Dissertação de Mestrado. São Paulo: FFLCH/USP (Letras), 1983.

${ }^{10}$ Anamaria Fadul (org.). Ficção seriada na TV: as telenovelas latino americanas com uma bibliografia anotada da telenovela brasileira. São Paulo: Núcleo de Pesquisa de Telenovelas, ECA-USP, 1992; Maria Lourdes Motter. Ficção e realidade: a construção do cotidiano na telenovela. São Paulo: Alexa Cultural, Comunicação \& Cultura, 2003; Maria Immacolata Vassalo de Lopes. Explorações metodológicas num estudo de recepção de telenovela. In: Temas Contemporâneos em Comunicação. São Paulo: INTERCOM, 1997, p. 151-166; Renata Pallotini. Dramaturgia de televisão. São Paulo: Editora Moderna, 1998.

${ }^{11}$ Jesús Martín-Barbero \& Germán Rey. Os exercícios do ver: hegemonia audiovisual e ficção televisiva. São Paulo: Editora SENAC/SP, 2001.

${ }^{12}$ Armand Mattelart \& Michèle Mattelart. O Carnaval das imagens: a ficção na TV. São Paulo: Brasiliense, 1989.

${ }^{13}$ Maria Ataíde Malcher. A memória da telenovela: legitimação e gerenciamento. São Paulo: Alexa Cultural, comunicação \&Cultura, 2003, p.55.
} 
como Marc Ferro e Past Imperfect, organizado por Marc C. Carnes. ${ }^{14}$ Porém, temos clareza que a ficção seriada televisiva não deve ser analisada como um filme, pois são produtos culturais diferentes, com públicos e objetivos também diversos. Mas, em nosso entender, em uma discussão interdisciplinar, os trabalhos analíticos sobre cinema podem trazer contribuições e idéias para serem utilizadas na metodologia de análise.

No caso de Marc Ferro, optamos por adaptar suas idéias gerais para análise cinema e história, porém respeitando o nosso objeto: o filme (minissérie) tem uma história que também é história; análise do produto dentro da cultura e da época em que foi produzido; diferenciar a leitura histórica do filme (minissérie) da leitura cinematográfica (teledramatúrgica) da história.

Entre os trabalhos sobre cinema e história no Brasil destacamos o de Eduardo Morettin, Cinema e história: uma análise do filme Os Bandeirantes. ${ }^{15}$ A obra analisada por Morettin, diferente das nossas que são ficções para entretenimento em veículo televisivo, é uma obra cinematográfica de caráter educativo, porém constitui um documento histórico que contribuiu para a imagem do paulista bandeirante. A mesma imagem foi usada por Dinah Silveira de Queiroz, e em conseqüência por Maria Adelaide Amaral.

Dentro da contribuição das obras especificas sobre teledramaturgia, temos além das já citadas, em especial o artigo de Maria Lourdes Motter: Argumentos para o estudo da ficção A Casa das Sete Mulheres; ficção, realidade e história ${ }^{16}$, que possibilitou o aprofundamento de aspectos de nossa análise, visto que o artigo utiliza uma minissérie histórica, inspirada na literatura e de autoria de Maria Adelaide.

Entre os trabalhos que inspiraram nossa análise, não podemos deixar de citar o de Marco Antônio Guerra sobre a obra de Carlos Queiroz Telles. História e Dramaturgia em

\footnotetext{
${ }^{14}$ Marc Ferro. Cinema e História. Rio de Janeiro: Paz e Terra, 1992, p.17; - O filme: uma contra-análise da sociedade? In: Jacques Le Goff. \& Pierre Nora. História: novos objetos. Rio de Janeiro: Francisco Alves, 1986; Marc C. Carnes(org.). Past imperfect: history according to the movies. New York: Owl Book, 1995.

15 Eduardo Victorio Morettin. Cinema e história: uma análise do filme Os Bandeirantes. Dissertação de Mestrado. São Paulo: ECA/USP (Departamento de Cinema Rádio e Televisão), 1994.

${ }^{16}$ Maria Lourdes Motter. Argumentos para o estudo da ficção A Casa das Sete Mulheres; ficção, realidade e história. Revista ECO-Pós, Rio de Janeiro, vol. 7, n 1, jan./jul., 2004, p.85-99.
} 
Cena (década de 70) ${ }^{17}$. O livro oferece subsídios metodológicos e teóricos para trabalhos relacionados à dramaturgia e história.

Quanto ao campo de estudo, este é um trabalho que discute questões atuais da produção cultural de massa no Brasil, inserido no campo de estudos culturais, na perspectiva de história do tempo presente. Entre os trabalhos sobre história do tempo presente utilizamos uma coletânea de artigos Questões para a história do presente. ${ }^{18}$

Nosso objeto de estudo articula simultaneamente presente e passado, pois explora o passado histórico e interage com o contemporâneo e as necessidades atuais do mercado. A articulação com o contemporâneo se reforça, visto que seus produtores continuam trabalhando, lançando novos produtos, referenciando-se a informações das produções passadas, que sofrem constate releitura.

Em nosso ponto de partida para a pesquisa, elaboramos algumas questões: por que a teledramaturgia pode ser entendida como uma obra coletiva? Quais são os produtores de uma obra de teledramaturgia (emissora, autores, atores, diretores etc.)? Qual a participação deles na produção? Que visão de história têm esses produtores? Esta visão é consciente ou não? Qual é o tipo de pesquisa histórica feita para essas produções? Que fontes são utilizadas? Como elas são utilizadas? Qual a história de cada produção? Qual o sucesso comercial que elas podem ter? Como esse material pode ser utilizado para ensinar história? Algumas dessas questões tentamos resolver no decorrer do trabalho e outras ficarão para uma próxima etapa.

A estrutura do texto está articulada em cinco capítulos e três anexos.

No capítulo 1, estudamos a história de A Muralha, levantando informações sobre as outras versões da obra literária para a televisão, sendo que a mais conhecida era a da TV Excelsior, de 1968. Comentamos sobre a autora do livro, Dinah Silveira de Queiroz, o contexto de produção da obra, no IV Centenário de São Paulo. Fazemos um resumo da obra literária, descrevendo partes que consideramos importantes para o entendimento posterior

\footnotetext{
${ }^{17}$ Marco Antônio Guerra. Carlos Queiroz Telles: história e dramaturgia em cena (década de 70). São Paulo: Annablume, 1993.

${ }^{18}$ Agnès Chauveau \&Philippe Tétard. Questões para a história do presente. Bauru, SP: EDUSC, 1999.
} 
na construção da trama da minissérie e que indicam visões sobre a Vila de São Paulo e seus habitantes. E contamos a história da produção de 2000, da Rede Globo, feita em comemoração aos 500 Anos do Descobrimento do Brasil, com um resumo da minissérie.

O capítulo 2 tem como objeto ainda a minissérie A Muralha, porém aí trabalhamos alguns temas escolhidos, como o cotidiano e a condição feminina, e apresentamos algumas das fontes históricas utilizadas pelos produtores para escrevê-la É importante ressaltar que a minissérie teve sua ação passada no início do século XVII, enquanto no livro a ação passava no início do século XVIII. Apresentamos como foram utilizados alguns autores conhecidos da historiografia sobre São Paulo. Indicamos também outros temas abordados na minissérie.

No capítulo 3, tratamos da minissérie Um Só Coração. E contamos a história dessa produção, que foi concebida em homenagem ao aniversário de 450 anos da Cidade de São Paulo. Foi uma minissérie bastante promovida em eventos culturais na cidade, especialmente em exposições em museus. E teve vários produtos criados em função de sua apresentação, tais como um $\mathrm{CD}$, com a trilha sonora, livros sobre a minissérie e suas personagens e até revistas populares, sobre acontecimentos históricos retratados na minissérie. Também neste capítulo fazemos um resumo da minissérie.

O capítulo 4 também é sobre Um Só Coração, tratando os temas da minissérie, que teve como fio condutor a vida de Yolanda Penteado. O principal objetivo da minissérie, segundo seus autores era contar a história de São Paulo do ponto de vista da cultura e a Yolanda Penteado ficcional era uma pessoa ligada a diversos momentos da cultura da cidade. Além da cultura, foram mostrados aspectos políticos, econômicos e sociais do período, sendo que a Revolução Constitucionalista de 1932 foi o mais destacado na minissérie. Nele também trabalhamos com algumas fontes bibliográficas sobre o período e suas personagens.

No capítulo 5, falamos sobre os produtores, entendendo a teledramaturgia como obra coletiva. Por razões de limitação de tempo e material disponível, tratamos mais da emissora Rede Globo, os autores, atores e diretores. Tentamos entender a relação que cada profissional tem com a produção e a visão de história de alguns deles.

Na Conclusão, nosso objetivo foi o de responder a questões que colocamos no início do projeto, com os elementos que conseguimos obter no cruzamento entre as produções 
culturais televisivas, as minisséries de cunho histórico e as obras historiográficas que serviram de fontes de informação, e mais do que isso, fontes de inspiração de elementos emocionais para a construção da narrativa folhetinesca.

As edições em DVD de ambas as minisséries foram utilizadas como fontes principais para a pesquisa. A forma de análise do conteúdo seguiu aproximadamente a decupagem, sem a discriminação quadro a quadro pela duração das obras.

Entrevistamos a autora Maria Adelaide Amaral e o ator Renato Scarpin. Utilizamos matérias de jornais da época, especialmente da Folha de S. Paulo, sobre as minisséries e seus produtores, além da bibliografia sobre teledramaturgia e sobre os temas das minisséries.

Percebemos, no transcurso da pesquisa que a história é vista como fonte para argumentos para as minisséries. A história serve como cenário e "pano de fundo" de histórias de vida, carregadas de emoção e contadas nas regras do folhetim tradicional. Daí, a presença dos anacronismos, especialmente nos relacionamentos entre as personagens, ou mesmo em algumas de suas posturas, pois na estrutura folhetinesca há a necessidade de criação de heróis e vilões.

A emissora Globo não foi vista como única responsável pelo produto final, embora como empresa, atenda às normas de administração profissional, em que cada um tem sua função. Não cabe ao autor discutir as necessidades de mercado e de capital da emissora. Os projetos são aprovados, recusados, ou modificados, em função dos custos e da aceitação do mercado.

A audiência é um fator muito importante para a produção de uma telenovela. No caso do formato minissérie, o peso é menor. A minissérie é uma obra fechada, com um número menor de capítulos, porém constitui um dos produtos mais caros da emissora. É apresentado por seus produtores como um produto cultural mais elaborado, com temas históricos e culturais. Para eles, o objetivo é despertar o interesse do público sobre um determinado assunto. E mesmo sem ser um produto com fim educativo, assume esse aspecto, na medida em que estimula o interesse dos telespectadores. 
E o interesse despertado é grande, graças à audiência, que também é responsável pela manutenção desse tipo de produção. A presença de Maria Adelaide Amaral nesses projetos é muito significativa, pois é a sua forma de construção de narrativa televisiva que tem marcado, no presente momento, as minisséries de cunho histórico.

$\mathrm{Na}$ estrutura do texto, definimos que as obras estão citadas em cada capítulo, pela variedade de títulos e autor, e, as notas de rodapé estão organizadas por capítulo, pela quantidade. 


\section{CAPÍTULO I - A MURALHA}

Este capítulo tem como objeto a descrição da minissérie histórica A Murallha, produzida em 2001. Esta produção é classificada como remake e é a quinta versão em teledramaturgia de uma obra literária nacional. Devido a essas informações, consideramos importante pesquisar sobre as versões anteriores e também sobre a obra literária, resgatando a história do produto cultural. Em decorrência, estruturamos o capítulo nos itens: as versões anteriores; a obra literária original e sua autora; a proposta de produção da teledramaturgia com objetivo de comemorar um evento histórico e a descrição da minissérie e seu conteúdo.

Na produção cultural audiovisual de massa existe a prática de atualizar obras que tiveram impacto em termos de público, contribuição técnica, narrativa ou inovação de conteúdo. A produção cinematográfica contemporânea realiza muitas novas versões de obras cinematográficas, de diversos modos: atualiza a linguagem; altera o espaço e o tempo da narrativa original; faz a releitura nos conceitos vigentes, alterando narrativas clássicas etc.

Na produção televisiva nacional acontece a mesma prática, e já há uma tradição de remakes ,tanto no Brasil, como em outros países da América Latina. O remake é uma nova versão de uma história já produzida, refeita por outros produtores. Ultimamente, as empresas emissoras têm trabalhado muito com remakes, em busca de público, partindo da premissa de que a memória da narrativa o atrairá, pois aproveitam histórias conhecidas e que tiveram audiência. Entre outros fatores que estimulam a produção de remakes atualmente, especialistas apontam: possibilidade de revelar antigos sucessos a novas audiências, redução de custos, releitura aperfeiçoada da própria obra pelo autor ou por outros e possibilidade de repensar o passado. Há especialistas que defendem que a prática não está associada à escassez de autores; outros a vêem como um fenômeno normal dentro da indústria cultural. ${ }^{1}$

$\mathrm{Na}$ prática concreta da produção televisiva, nem sempre o remake consegue o mesmo sucesso da versão anterior. Esta prática não tem a obrigação de fidelidade à história

\footnotetext{
${ }^{1}$ Marcelo Bartolomei. Especialista elogia "sessão nostalgia". Folha de S. Paulo, 12/03/2006, caderno Ilustrada, p E6. Os especialistas consultados na reportagem, Gabriel Priolli, Maria Immacolata Vassallo de Lopes e Raquel Paiva, indicam vários motivos que favorecem a prática de remakes e reprises de telenovelas.
} 
original. Exemplificando, no remake de Anjo Mau (1997), Maria Adelaide Amaral mudou o ambiente da história do Rio de Janeiro para São Paulo e alterou o final de modo que a personagem Nice, que morreu na primeira versão, devidamente castigada por ser a vilã, teve um final feliz. ${ }^{2}$

Além do remake, outra prática comum na teledramaturgia nacional é o uso da literatura como fonte de inspiração:

\begin{abstract}
"O texto literário, no entanto, desempenhou papel peculiar nos programas de ficção veiculados pela TV. Desde a instalação da televisão no Brasil, os programas de maior prestígio/audiência das diversas emissoras regularmente realizam adaptações de textos literários. Nos anos 50, os teleteatros consistiam basicamente da transposição para o vídeo de obras da literatura internacional. A mesma fórmula logo em seguida foi aplicada às telenovelas, que ganharam crescente popularidade até se tornarem, nos anos 60, fenômenos de audiência. Na década de 70, criou-se um horário para a exibição de telenovelas baseadas em textos literários, desta vez exclusivamente brasileiros. A partir do anos 80 , as adaptações de obras brasileiras deslocam-se para as minisséries."
\end{abstract}

Com o aumento de investimento em teledramaturgia nos últimos anos a literatura continua sendo utilizada como fonte de inspiração das histórias em diversos formatos, horários e emissoras.

\title{
1. VERSÕES DA MESMA HISTÓRIA
}

A Muralha, produzida pela Rede Globo, é a quinta versão de que se tem referência desta história na teledramaturgia. Ismael Fernandes indica três versões: a primeira, apresentada em 1958, pela TV Tupi; a segunda em 1963 pela TV Cultura e a terceira e mais conhecida, em 1968, pela TV Excelsior. ${ }^{4}$

Hélio Guimarães indica uma versão anterior, da TV Record, em 1954, ano da primeira edição do livro e da comemoração do IV Centenário de São Paulo. Em artigo publicado na Revista da USP ${ }^{5}$, apresenta algumas dificuldades de produção para a época.

\footnotetext{
${ }^{2}$ Dicionário da TV Globo, v.1: programas de dramaturgia \& entretenimento (Projeto Memória das Organizações Globo). Rio de Janeiro: Jorge Zahar Ed., 2003, p. 253.

${ }^{3}$ Hélio Guimarães. A presença da literatura na televisão. Revista USP, São Paulo, 32, dez. 1996/fev. 1997, p. 192.

${ }^{4}$ Ismael Fernandes. Memória da telenovela brasileira. $4^{\mathrm{a}}$ ed. São Paulo: Brasiliense, 1997, p.111.

${ }^{5}$ Hélio Guimarães. op. cit, p. 190-198.
} 
A maioria das adaptações de livros para a televisão era baseada na literatura estrangeira, que já possuía versões cinematográficas. A versão cinematográfica facilitava o trabalho, pois os profissionais de então não tinham experiência em transpor o texto diretamente para um meio audiovisual, no caso a televisão. O filme era considerado uma importante fonte de inspiração, pois o trabalho de imaginação, com a criação de cenários, diálogos e caracterização de personagens, já estava feito. E também havia dificuldades técnicas em usar obras da literatura brasileira:

“(...). Uma das tentativas ocorreu em 1954, quando a Record exibiu A Muralha, telenovela baseada na obra de Dinah Silveira de Queirós (sic). O depoimento do adaptador e diretor, Miroel Silveira, dá idéia da dificuldade que foi adaptar o romance para um veículo que se constituía basicamente de imagens e sons. Silveira conta que a telenovela era exibida ao vivo três vezes por semana. Tudo era feito em estúdio e, portanto, não havia possibilidade de cenas externas. Como o romance se passa durante a Guerra dos Emboabas, no capítulo em que deveriam ser apresentadas cenas da guerra, a solução foi a seguinte: 'Nós tivemos como único recurso convidar a autora, que veio do Rio de Janeiro e contou a Guerra dos Emboabas num capítulo especial, que era uma entrevista.'

O depoimento de Silveira ilustra a inexperiência em contar uma história através de imagens e o desconhecimento de recursos narrativos da televisão. " 6

Dentre as versões antigas, a mais conhecida é a da Excelsior, escrita por Ivani Ribeiro. Contava no elenco com atores como Mauro Mendonça (Dom Braz), Fernanda Montenegro (Mãe Cândida), Nathália Timberg (Basiléia), Gianfrancesco Guarnieri (Leonel), Nicette Bruno (Margarida), Rosamaria Murtinho (Isabel), Stênio Garcia (Aimbé), Paulo Goulart (Bento Coutinho), Maria Isabel de Lizandra (Rosália), Edgar Franco (Tiago), Arlete Montenegro (Cristina), entre outros. Foi apresentada em 216 capítulos, entre julho de 1968 a março de 1969, com direção de Sérgio Britto e Gonzaga Blota. Foi considerada na época uma super produção e um grande sucesso. ${ }^{7}$

Nas reportagens publicadas pela revista Realidade $^{8}$, encontramos informações semelhantes ao que ocorre atualmente na produção de uma telenovela histórica. $\mathrm{O}$ diretor Sérgio Britto fala sobre as dificuldades com os cenários, que eram tantos que não couberam nos imensos estúdios da TV Excelsior, na Vila Guilherme. Também a reportagem ressalta a importância da pesquisa cenográfica de Luiz Marinho:

\footnotetext{
${ }^{6}$ Idem, p. 194-195.

${ }^{7}$ Ismael Fernandes. op. cit, p.110-111.
} 
"Procurando reconstituir fielmente o tempo dos bandeirantes, Sérgio Brito escolheu tal número de cenários e objetos de decoração que não couberam num dos estúdiosgigantes da TV Excelsior de São Paulo. Na pesquisa que a respeito empreendeu contou com a experiência e o bom gôsto (sic) do cenógrafo Luiz Marinho."9

E indica as locações como o Pátio do Colégio, a Casa dos Bandeirantes e lugares históricos do interior.

Em outra reportagem, acrescenta mais informações sobre a produção na época:

"Sérgio Brito acha que a realização de uma super-produção dessa natureza é bastante trabalhosa, principalmente com as tomadas externas, como a que fizeram na aldeia de Carapicuíba, arredores de São Paulo, onde tiveram que montar o pôrto (sic) de Santos no século XVI para receber um navio português. - 'É bastante cansativo' - conclui. 'Aliás como toda novela de época.'. ",

Nesta mesma reportagem, encontramos a informação de quanto a audiência já era importante e determinante:

“A novela está prevista para uma duração de seis meses -'mas poderá se prolongar por mais tempo, dependendo do índice de audiência' - explica Sérgio Brito.","

A visão de história dos atores e o objetivo da produção também possuem semelhanças com a versão mais recente. Na declaração de Paulo Goulart:

"É uma novela muito importante, porque, além de mostrar os costumes de uma época, que são perfeitamente válidos em nossos dias, tem o caráter de divulgação da nossa história." $" 12$

Identificamos nessas reportagens várias semelhanças com as produções estudadas e a produção de teledramaturgia atual: a preocupação em divulgar a história aparece constantemente nos discursos dos produtores; as dificuldades técnicas com cenários e reconstituição e a interferência da audiência na produção, que no caso prolongou a duração da novela.

\footnotetext{
${ }^{8}$ Não é fácil construir A Muralha. Realidade, São Paulo, nº 286, ano VI, 30/jun. a 6/jul., 1968, p. 16-17.

${ }^{9}$ Idem, p.17.

10 Paulo Stein. A Muralha: as emoções da história. Realidade, São Paulo, nº 290, ano VI, 28/jul. a 03/ago., 1968 , p.26.

${ }^{11}$ Idem.
} 


\section{Imagens não disponíveis para} internet.

Imagens de A Muralha, produzida pela TV Excelsior em 1968.

\section{A OBRA LITERÁRIA E SUA AUTORA}

Antonio Candido no artigo intitulado "Aspectos sociais da literatura em S. Paulo" conclui com a seguinte idéia: “(...). Há uma história da literatura que se projeta na cidade de S. Paulo; e há uma história da cidade de S. Paulo que se projeta na literatura." ${ }^{13}$ Partindo dessa idéia, procuramos inserir a autora Dinah Silveira de Queiroz e A Muralha dentro das manifestações da literatura brasileira em São Paulo, em especial no que da história de São Paulo se projeta na literatura. Também indicamos a necessidade de conhecimento sobre a obra, a autora e a narrativa literária para entender o andamento da trama televisiva. Alguns aspectos são herdados do romance e constituem anacronismos. Não tivemos acesso à pesquisa de Dinah Silveira de Queiroz para o romance, mas identificamos algumas partes do livro ao descrever a narrativa literária que, se não foram usados fielmente na TV, serviram de inspiração.

O livro A Muralha tem como tema geral a vida de uma família de bandeirantes no início do século XVIII. O grande acontecimento histórico da trama é a Guerra dos

\footnotetext{
${ }^{12}$ Idem.

${ }^{13}$ Antonio Candido. Aspectos sociais da literatura em S. Paulo. In: Ensaios paulistas: contribuição de O Estado de São Paulo às comemorações do IV Centenário da cidade. São Paulo: Editora Anhambi S/A, 1958, p.214.
} 
Emboabas, entre 1707 e 1709. ${ }^{14}$ Algumas personagens históricas como Manuel de Borba Gato, Manuel Nunes Viana e Bento do Amaral Coutinho são também personagens da obra literária.

O episódio da batalha do Capão da Traição, em 1708, aparece no enredo, reforçando a paulistanidade. $\mathrm{O}$ orgulho, o sentimento de nacionalidade paulista e superioridade estão retratados em toda a obra. Esse tipo de sentimento, aliado à força da modernidade e do desenvolvimento econômico e cultural de São Paulo, esteve extremamente presente nas comemorações do IV Centenário da fundação da cidade, em 1954, ano em que o livro foi publicado pela primeira vez. Antes, o romance foi apresentado em capítulos, na revista $O$ Cruzeiro. ${ }^{15}$

\section{A autora}

A autora Dinah Silveira de Queiroz nasceu em São Paulo em 1911 e faleceu no Rio de Janeiro, em 1982. É descendente de família considerada bandeirante, cujo patriarca era Carlos Pedroso da Silveira ${ }^{16}$. Estudou no Colégio Des Oiseaux e lançou pela José Olympio seu primeiro livro, Floradas na Serra, em 1939. Este livro inspirou um filme homônimo, em 1955, da Companhia Cinematográfica Vera Cruz, estrelado por Cacilda Becker e Jardel Filho. É autora de vasta obra que inclui sete romances para adultos, quatro coleções de contos, uma de crônicas, livros de histórias infantis, uma peça teatral e uma antologia. Várias de suas obras foram traduzidas e publicadas no exterior.

Entre suas obras, além das já citadas, encontram-se os títulos: A sereia verde (1941); Margarida de La Rocque - a Ilha dos Demônios (1949); As aventuras do homem vegetal

\footnotetext{
14 “(...).Termo (emboaba) muito utilizado pelos paulistas no sertão da Bahia e de Minas Gerais para designar a guerra civil travada entre paulistas e os grupos recém chegados à região das Minas, entre 1707 e 1709. Com a descoberta de ouro pelos paulistas, no final do século XVII, um número muito grande de aventureiros passou a circular em Minas em busca do enriquecimento rápido, oriundos de Portugal e de diversas capitanias, sobretudo da Bahia.(...)." IN: Ronaldo Vainfas (org.). Dicionário do Brasil Colonial (1500-1808). Rio de Janeiro: Objetiva, 2001, p. 270.

${ }^{15}$ Nota da editora: dados bibliográficos da autora. In: Dinah Silveira Queiroz. Floradas na serra. $20^{\mathrm{a}}$ ed. Rio de Janeiro: Livraria José Olympio Editora, 1981, p.vi.

${ }^{16} \mathrm{O}$ pai de Margarida, personagem de A Muralha, se chama Carlos Pedroso. In: Dinah Silveira de Queiroz. A

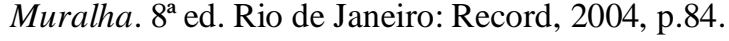


(1951); O oitavo dia (1956), As noites do Morro do Encanto (1957); Era uma vez uma princesa... - Isabel, a Redentora (1960); Eles herdarão a terra (1960); Os invasores (1965); A princesa dos escravos (1966); Verão dos infiéis (1968); Comba Malina (1969); O livro dos transportes (1969); Café da manhã (1969); Seleta (1974); Eu venho - Memorial do Cristo I (1974), Eu, Jesus - Memorial do Cristo II (1977). ${ }^{17}$

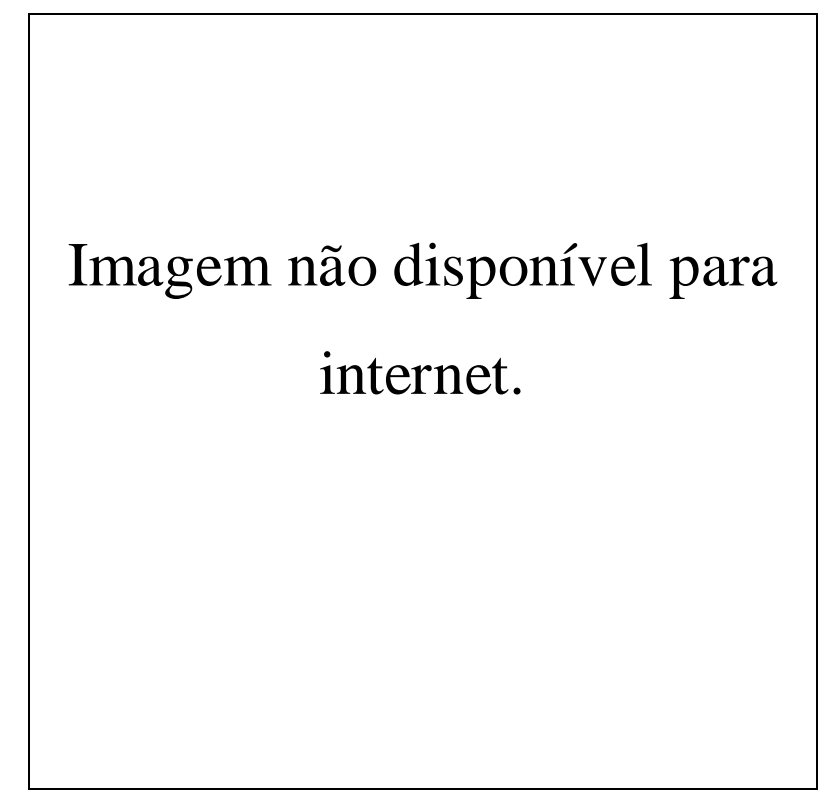

A autora Dinah Silveira de Queiroz

A relação com o universo intelectual foi constante na vida de Dinah Silveira de Queiroz. Entre seus parentes próximos, muitos se dedicaram às letras, como contistas, romancistas, cronistas, poetas, tradutores, novelistas e enciclopedistas. Um de seus primos é o teatrólogo Miroel Silveira, que foi adaptador e diretor da primeira versão de A Muralha para a TV, feita pela Record, em 1954.

\footnotetext{
${ }^{17}$ As informações sobre Dinah Silveira de Queiroz foram retiradas de: Nota da editora: dados bibliográficos da autora. In: Dinah Silveira Queiroz. Floradas na serra. $20^{\mathrm{a}}$ ed. Rio de Janeiro: Livraria José Olympio Editora, 1981, p. v a x; Malcon Silverman. Moderna ficção brasileira 2. Rio de Janeiro: Civilização Brasileira; Brasília: INL, 1981, p. 28; e site www.biblio.com.br/Templates/biografias/dinahsilveiradequeiroz.htm
} 


\section{A narrativa literária}

Na primeira parte do livro A Muralha, intitulada "Descoberta da Terra", foi narrada a chegada de Cristina à colônia. Ela era portuguesa do reino e veio para se casar com seu primo Tiago Olinto. Uma fala de Dom Braz, no livro, oferece a indicação da necessidade de buscar uma noiva em Portugal, devido à escassez de mulheres brancas na nova terra. No caso, Cristina era de boa origem, da própria família:

“- Com quem ia se casar Tiago? Com alguma negra, alguma índia? Todo branco que tem filha casadoura e é de altura de minha casa já tratou noivo para ela.(...). Casar por conta própria é um negócio desgraçado e infeliz. Eu sei muito bem que vosmecê é mulher de bom molde e de boa raça. (...)."18

Mas não eram apenas as mulheres de boas famílias que vinham para a nova terra em busca de casamento. Junto com Cristina, veio uma prostituta, Joana Antônia, como a prometida de Davidão, um comerciante. Através desta personagem, o texto passou a idéia de que a necessidade de mulheres brancas fazia com que mesmo prostitutas fossem aceitas como esposas.

Cristina chegou a São Vicente e foi recebida por Aimbé, mestiço, criado de Dom Braz, que deveria acompanhá-la até a Lagoa Serena, fazenda da família, próxima à vila de São Paulo de Piratininga.

Começou aí a descoberta da nova terra e dos costumes para a jovem Cristina, que veio com expectativas românticas sobre seu noivo e sobre a riqueza. A viagem foi difícil, cheia de perigos e de decepções, mas ela estava motivada pelo amor que já sentia pelo noivo:

“(...). Como em toda moça de dezoito anos, nela o amor estava muito próximo da idéia de céu merecido à custa de sofrimento. Se Piratininga estava longe, se tudo que sofrera de cansaço até agora lhe atormentava o ânimo, nem por isso perdia a fé naquilo em que seu ser obscuramente acreditava. Tiago seria um prêmio. Tiago não a decepcionaria. (...).",19

\footnotetext{
${ }^{18}$ Parte de diálogo de Dom Braz com Cristina. In: Dinah Silveira de Queiroz. A Muralha, op.cit., p. 101.

${ }^{19}$ Dinah Silveira de Queiroz. A Muralha, op.cit., p.31-32.
} 
Tão decepcionante quanto a viagem, foi sua chegada a São Paulo de Piratininga. Nem o noivo, nem ninguém da família veio recebê-la. Sua decepção também foi grande com o que era a vila na época:

"Atravessaram uma várzea. Acima dos barrancos se alinhavam casas pobres, de taipa. Mas havia em São Paulo de Piratininga uma altivez incompreensível. Da várzea, as pequenas casas pareciam crescidas naquele aumento de barranco. Cristina pensou, uma raiva surda a lhe apertar a garganta: 'Tanta pena, tanto cansaço; uma subida como se nós fôssemos à catedral do topo do mundo! $\mathrm{E}$ ao chegarmos...isto: uma pouca sujeira .' Lembra-se do que Aimbé lhe havia dito: Piratininga bela - e não ria porque estava tão acabrunhada, que não podia imaginar quando poderia dispor da naturalidade de seu riso."20

Aproximadamente três a quatro horas de distância, chegou à Lagoa Serena, descrita da seguinte forma:

"Muito tempo depois ela se lembraria da primeira visão que tivera da Lagoa Serena. A lagoa, rente à pequena aldeia de casas e de compartimentos da Fazenda; e, descendo a encosta, os bois carregando um carro transbordando de lenha. Os edifícios - muitos -, a casa alta, de taipa, com uma varanda, e mandando ao ar um fumaceiro alegre; o moinho, as casas menores, o paiol, o muro a cercar a linha edificada no mar de vegetação, e, diante do muro, no chão limpo, uma fila estranha, toda composta de mulheres. Ao centro, a cabeça altiva e branca de Mãe Cândida, batida de luz, os cabelos soprados pelo vento da tarde. E ao lado, as filhas, a nora, todas com ar cerimonioso e ao mesmo tempo simples de disciplina. (...), ${ }^{\text {,21 }}$

\footnotetext{
${ }^{20}$ Idem, p.42-43.

${ }^{21}$ Idem, p. 44.
} 


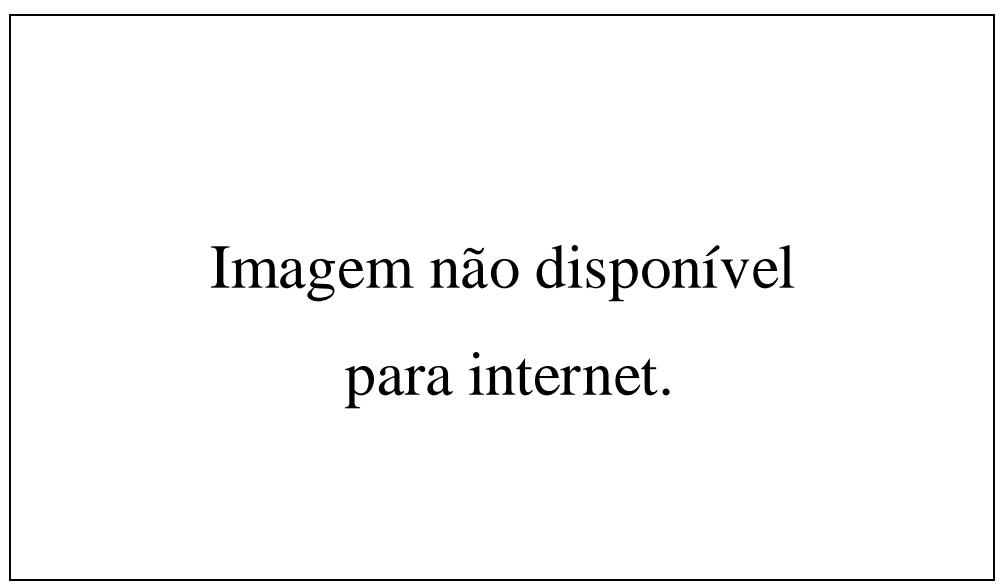

Vista de Lagoa Serena na minissérie.

Uma das impressões mais fortes era que: “(...). Havia em tudo, uma extravagante mescla de imponência e pobreza, que feriu o coração de Cristina. (...).,22

Mais uma vez Cristina se decepcionou: seu noivo não se encontrava. Estava em viagem com os outros homens pelo sertão. A moça se deparou com a realidade: passaria o tempo com as mulheres da família: Mãe Cândida, a mãe de Tiago; as irmãs, Basília e Rosália e a cunhada, Margarida - personagens que apresentam o papel da mulher e o cotidiano dessa sociedade:

“- O pior vosmecê não sabe. O mulherio daqui já aprendeu a mandar. E, quando a gente vive morrendo de saudade, tem que ir fazendo trabalho dos homens, vigiando as fazendas, as lavouras, senão tudo acaba. Vosmecê não faz nem idéia do matão que existe cobrindo por aí as lavouras do tempo de dantes. As mulheres que quiseram continuar com suas casas bem postas e a criadagem e os escravos bem mandados, têm de ter mando de homem e energia de homem. Por isso, muita vez, quando eles chegam, encontram o escravo pedindo primeiro permissão para à dona, porque as mulheres, aqui, são fiéis no amor, mas, com essas distâncias e essas incertezas, sempre fazem de conta que são viúvas, sem o ser. E quando os maridos chegam, aqueles que têm mesa posta, escravaria bem guardada, casa bem preparada, também encontra mulher mandona."23

\footnotetext{
${ }^{22}$ Idem, p.44-45.

${ }^{23}$ Idem, p.77.
} 
A passagem acima é de um diálogo entre Margarida e Cristina, as duas cunhadas. Margarida também era diferente das outras mulheres de Lagoa Serena: delicada, sensível e culta. Sabia escrever e dedicava-se à poesia. Amava seu marido e era correspondida. Vivia em uma casa enfeitada, com rosas e um papagaio. Margarida pode ser considerada uma personagem com características anacrônicas para o momento histórico que o livro procurava retratar, especialmente por ser nascida na colônia, em Taubaté. Esse anacronismo é completamente absorvido na composição da personagem na minissérie. ${ }^{24}$

As outras mulheres estavam mais próximas da descrição efetuada por Margarida no diálogo com Cristina, acima citado: Mãe Cândida no comando da fazenda e da família; Basília, a filha mais velha, solteira e descrita como uma mulher feia, que ajudava à mãe e, no decorrer do livro, herda características dela em atitudes e postura. Rosália ${ }^{25}$, a caçula, é mais romântica e sonhadora e dedicava-se à atividade no comércio:

“(...). Rosália tinha o orgulho de ter seu próprio comércio e mandar caixas e caixas de marmelada para longe dali. Todas as mulheres se ocupavam em trabalhos rendosos. Era extraordinário. Havendo tanto esforço e tanto êxito, faltava todo e qualquer luxo e conforto a tais mulheres. Cristina acabou pensando que isso se devia ao fato de que Lagoa Serena tinha bocas demais, vidas demais, para serem nutridas e agasalhadas." 26

Cristina estranhou profundamente a vida dessas mulheres e se ligou mais à Margarida, por suas características diferentes e por esta servir de amparo e orientação para se habituar à nova vida e à nova terra. Na passagem acima, além de informações do cotidiano da mulher, identificamos o aspecto econômico: apesar de tanto trabalho, predominava uma vida muito simples.

\footnotetext{
${ }^{24}$ A presença de uma poetisa ficcional em São Paulo nessa época, provavelmente é uma referência ou foi inpirada na poetisa Teresa Margarida da Silva e Orta, nascida em São Paulo em 1711 ou 1712 e falecida em Lisboa em 1793. Atentamos para o fato da obra de Teresa Margarida ter sido considerada de caráter e propaganda antiabsolutista em Portugal e a suposta obra de Margarida eram versos para lembrar o marido ausente no sertão. Sobre Teresa Margarida ver: Rubens Borba de Moraes. Bibliografia brasileira do período colonial: catálogo comentado das obras dos autores nascidos no Brasil e publicadas antes de 1808. São Paulo: IEB, 1969, p.263-271.

${ }^{25}$ As histórias de Basília e Rosália foram um pouco modificadas na minissérie, porém consideramos que a essência psicológica das personagens foi mantida.

${ }^{26}$ Dinah Silveira de Queiroz. A Muralha, op.cit., p. 58.
} 
Tudo em São Paulo era assim na visão de Cristina, “....uma estranha união de fartura e de miséria. (...)." ${ }^{27}$ Estranhava todos os costumes, do modo de viver a forma tratamento entre as pessoas.

Esta parte do livro se encerrou com o casamento e a noite de núpcias de Cristina e Tiago.

A segunda parte do livro foi intitulada "A Madama do Anjo" e fez referência ao culto à Virgem Maria ${ }^{28}$. Nesta parte, revelou-se a relação entre Tiago e sua prima Isabel. Ela tinha a força e a rudez das mulheres de Lagoa Serena, porém era mais hostil e masculinizada.

Isabel vivia com os homens no sertão e em muitos aspectos se comportava como eles. Era como um outro filho de Dom Braz. Cuidava de sua onça, Morena, com mais amor do que qualquer pessoa. Sua relação com Tiago era de hostilidade, mas encobria uma atração, que acabou gerando um filho bastardo.

De início, não se sabe quem era o pai do filho de Isabel. Acreditava-se que o pai era o índio Apingorá, que já havia servido à família de Dom Braz e vivia em uma aldeia com os seus. Leonel, marido de Margarida, foi à aldeia vingar a honra da família, mata Apingorá e incendeia o local.

A incerteza da paternidade do filho de Isabel gerou dúvidas sobre a fidelidade de Leonel à Margarida, agravando os problemas de saúde que a levaram à morte.

$\mathrm{O}$ ato de Leonel teve conseqüências trágicas para Lagoa Serena. Revidando seu ataque, os índios atacaram a fazenda, destruíram suas plantações e tentaram matar todos os seus habitantes. ${ }^{29}$

Mãe Cândida, Isabel, Cristina e Basília lutaram por sua sobrevivência, cada uma a seu modo. Quando ocorreu o ataque, as mulheres estavam sozinhas, pois Dom Braz e Tiago haviam partido em bandeira e Leonel, após a morte de Margarida, perdeu-se no sertão. ${ }^{30}$

Rosália fugiu com o aventureiro Bento Coutinho para as Minas Gerais, ganhando a proteção de Manoel Nunes Viana, chefe dos emboabas.

\footnotetext{
${ }^{27}$ Idem, p. 118.

28 “(...). Cristina, num abatimento enorme, os olhos a se esconderem de todos, se sentava junto da Virgem, cuja lamparina estava apagada. (...).” Idem, p.99.

${ }^{29}$ Estas histórias foram retratadas na minissérie.

${ }^{30}$ No livro, Leonel não retorna para a família. Na minissérie, a personagem volta para se unir ao irmão na busca por ouro em Sabarabuçu.
} 
Cristina viu-se cada vez mais infeliz e revoltada, vivendo um casamento frustrado em seus sonhos românticos, além de sofrer com as diferenças de costumes.

Nesta parte do livro foi narrado o episódio da luta entre paulistas e portugueses, os emboabas. Após a vitória, parte desse grupo sob a liderança de Dom Braz foi massacrado por homens de Bento Coutinho, no Capão da Traição. ${ }^{31}$

A terceira parte é a "Canção de Margarida". Rosália fugiu de Bento Coutinho, ao saber o que este fez com os paulistas. A rotina da vila se modificou com a morte de seus homens. Os que sobreviveram foram mal recebidos, pois eram considerados motivo de vergonha para suas mulheres:

“(...). Subia o ouro ao planalto havia já o luxo, continuamente, tangiam os sinos pelos mortos de São Paulo. As igrejas estavam sempre plenas de mulheres embuçadas tristemente em seus véus, a rezarem por seus irmãos, pais ou maridos. Às vezes, sabedoras de suas mortes - às vezes postas ali porque haviam sonhado, à noite, que eles pereciam esfaqueados, ou então de tiro, no meio do mato. Pior que a certeza era a incerteza trágica desses dias. Já não havia o mesmo resguardo, a mesma separação entre homens e mulheres naquela habitual e austera cerimônia. As paulistas não ficavam mais fechadas em casa; iam à rua como os homens, no desespero de saber notícias, de indagar. A Vila (sic) vivia como uma única família." 32

"Havia a brutal reação contra os que voltavam à terra, depois do morticínio. As donas de São Paulo não compreendiam a volta dos seus maridos, após aquela vergonha. Por que não foram às minas, vingar os trezentos mortos? Como poderiam entrar de novo em São Paulo do Campo de Piratininga, se estavam desonrados com a morte de seus companheiros? De boca para boca se despejavam as expressões de escândalo, de humilhação e de vergonha. Não queriam saber de mais razões. Os que haviam voltado eram renegados. A caçoada trágica rebentava num e noutro canto das ladeiras da Vila (sic). ",33

A personagem Cristina assumiu um ar profético sobre o destino da vila de São Paulo, que já trazia o sinal do orgulho que nela ia crescer: “... Esta gente está sendo castigada de seu pecado'., 34

\footnotetext{
${ }^{31}$ Ronaldo Vainfas (org.). Dicionário do Brasil Colonial, op. cit., p. 271.

${ }^{32}$ Dinah Silveira de Queiroz. A Muralha, op.cit., p.348

${ }^{33}$ Idem, p.356.

${ }^{34}$ Idem, p. 348 .
} 
As mulheres de Lagoa Serena se modificaram com a morte de seus homens. Mãe Cândida envelheceu rapidamente e não demonstrou ter a mesma força de antes. Rosália voltou a viver com a família. Basília se tornou mais rígida e tomou a atitude de doar todo o ouro do pai para uma guerra que tinha como o objetivo de lavar a honra de São Paulo.

Cristina, que vivia insatisfeita e pensava em abandonar Tiago e voltar para o reino, acreditava estar viúva. Chamada à casa de Joana Antônia, descobre que seu marido estava vivo e fora salvo por Davidão. Mesmo assim, quer partir. Tentou de várias maneiras escapar da responsabilidade em relação a Tiago, mas não conseguiu, pois as mulheres da Vila não tiveram compreensão por sua sobrevivência, assim como não teve Mãe Cândida, quando Cristina o levou doente para Lagoa Serena.

E presa àquele lugar, levou Tiago para a casa de Margarida e Leonel, que permanecera trancada desde o sepultamento da cunhada. Lá Tiago se recuperou sob os cuidados da esposa, que não desistiu de partir, apenas adiou o momento. Nesse período o casal encontrou oportunidades para um entendimento, que não aconteceu. Tiago não esclareceu para Cristina sua situação com Isabel.

No desenrolar da trama, Isabel, que não se importava com o filho, deixou a criança com Mãe Cândida e partiu com uma bandeira.

Posteriormente foi descoberto que Tiago não se acovardara na luta, mas tinha sido ferido. Sua família o quis de volta e ele foi escolhido para a expedição de Amador Bueno da Veiga contra os emboabas. Cristina fica cada vez mais revoltada por ter cuidado dele, enquanto sua mãe e irmãs se recusavam; e agora elas o queriam de volta e ainda o mandariam para a guerra para correr risco novamente. Era um mundo muito estranho para ela.

Decidida a partir, percorreu com Tiago o mesmo caminho que fez quando chegou. Através dela são apontadas mudanças em Piratininga. Grávida, não conseguiu partir e fez sua profecia sobre a grandeza da cidade: 
“- Com homens assim, assim loucos e teimosos, e mulheres tão atrevidas e obstinadas...sabes o que me veio agora à cabeça? Que esta sujeira... - e ela quase cuspiu de raiva naquele desafio à grandeza de Deus, mas se dobrou, cativa de imensidão - ...bem pode tornar-se, um dia, uma grande cidade." 35

\section{A MURALHA DA GLOBO}

No final de abril de 1999, Maria Adelaide e mais quatro autores (Dias Gomes, Lauro César Muniz, Sérgio Marques e Ferreira Gullar ${ }^{36}$ foram convocados por Daniel Filho, então diretor artístico da Globo, para uma reunião, na qual foram discutidos os projetos de cada um para celebrar os 500 anos do Descobrimento. A emissora pretendia celebrar a data, realizando uma minissérie de oito a vinte e quatro capítulos para cada século de história do país. Cada autor escolheu seu tema e seu século. Maria Adelaide foi a última a escolher e conta como foi em passagem de sua biografia:

“(...).Então quando chegou a minha vez, o Daniel me disse: Bom, sobrou o século XVI e o que você vai fazer' Eu disse: São Paulo - assim, sem pensar. Ele me perguntou o que seria São Paulo do século XVI, e respondi sem pensar: A Muralha. A Denise Sarraceni (sic), com quem eu faria parceria, disse que era boa idéia. $(\ldots),{ }^{37}$

A autora, que havia lido o romance ainda criança, confundiu o tempo histórico, pois a narrativa se passava no início do século XVIII e não XVI:

"Quando cheguei a São Paulo e descobri que a ação se desenrolava em 1708 e não no século XVI, meu primeiro pensamento foi: Me ferrei! Porém, logo em seguida concluí que o equívoco poderia ser contornado. Conservaria os personagens e a idéia central das tramas e mudaria o pano de fundo histórico. Ao invés de falar sobre as Minas Gerais e a Guerra dos Emboabas, iria falar sobre o início do Movimento Bandeirantista, ou seja, sobre aqueles homens que primeiro avançaram para o interior em busca de mão-de-obra indígena, quando o ouro ainda não era o

\footnotetext{
${ }^{35}$ Dinah Silveira de Queiroz. A Muralha, op.cit., p. 414. A idéia profética sobre São Paulo, no final do livro, foi mantida na minissérie

${ }^{36}$ Tuna Dwek. Maria Adelaide Amaral: a emoção libertária. São Paulo: Imprensa Oficial do Estado de São Paulo: Cultura - Fundação Padre Anchieta, 2005, p.221.

${ }^{37}$ Idem, p.222.
} 
objetivo principal. Era isso que iria fazer. Falar sobre os avós de Raposo Tavares e de Fernão Dias Paes."38

Mas a Globo não produziu nenhuma das outras minisséries previstas para a comemoração, em função das necessidades de recursos técnicos e financeiros e outras dificuldades que a produção de cinco minisséries ao mesmo tempo acarretaria. A justificativa é plausível, considerando o custo e o cuidado normalmente dado às produções de minisséries. Da mesma forma, para a realização do projeto inicial necessitariam de grande quantidade de profissionais, visto que por sua própria estrutura de programação tinham que levar em consideração as necessidades das produções em andamento e em exibição.

O fato de ser a única minissérie a ser produzida exigiu mais uma mudança para Maria Adelaide: o aumento do número de capítulos para 48:

“...desde que pudesse acrescentar novos personagens e novas tramas à história original. Me deram total liberdade, a Globo já tinha comprado os direitos autorais, e quando você compra os direitos o contrato já pressupõe que a história será modificada de acordo com as necessidades teledramatúrgicas. Em geral é o que acontece em minisséries mais longas. Nas curtas, os autores costumam se ater ao livro.

E foi assim que eu criei os personagens da Ana, interpretada por Letícia Sabatella, o Dom Jerônimo, de Tarcísio Meira, que abordei os marranos, ou seja, os judeus que seguiam seus rituais clandestinamente, que criei os personagens de Padre Simão e Padre Miguel, respectivamente, representados por Mateus Nachtergaele e Paulo José. Abordei o drama do que a evangelização representou, apesar das boas intenções da Companhia de Jesus de poupar os índios da escravidão porque eles tinham alma. Mostrei o que significou essa assimilação em termos de desintegração e de perda de referência cultural, o drama que foi essa catequização dos indígenas.

Era um assunto que sempre me seduziu e que, como no caso dos cristãos- novos, eram temas pouco conhecidos pelo grande público de televisão. (...)."

A versão de Maria Adelaide para A Muralha teve como cenário a vila de São Paulo de Piratininga, no início do século XVII. Esta é a referência de tempo indicada no DVD, porém em entrevista, a autora revelou que a ação se passou em $1612 .^{40}$

As justificativas apresentadas para a mudança de período histórico são bastante simples: "sobrou o século XVI" e o equívoco com o tempo do livro. Como ficcionista a

\footnotetext{
${ }^{38}$ Idem, p.223-224.

${ }^{39}$ Idem, p. 227-228

${ }^{40}$ Entrevista concedida pela autora Maria Adelaide Amaral para esta pesquisa.
} 
autora contornou a situação, aproveitando a trama central, com algumas alterações, enobrecendo personagens, criando vínculos afetivos que não existiam, novas tramas e novas personagens. Pela necessidade de mais capítulos do que o previsto, essa criação foi necessária. As modificações estavam autorizadas pela aquisição dos direitos autorais da obra literária.

Dadas as diversas mudanças de tempo, podemos encontrar elementos do final do século XVI, início do século XVII e também do século XVIII.

\section{A minissérie histórica}

A minissérie foi exibida em 49 capítulos, entre 4 de janeiro e 28 de março de 2000, às $22 \mathrm{~h} 30$. Segundo informações divulgadas na imprensa, o custo médio por capítulo foi de $\mathrm{R} \$ 220.000,00$ reais, e sua produção era considerada um risco. ${ }^{41}$ Houve locações em Xerém na Baixada Fluminense; a participação de cinqüenta índios de uma tribo Xavante do Xingu e mais dez de uma aldeia Guarani, perto de Angra dos Reis. ${ }^{42}$

Contou com a participação dos atores Mauro Mendonça e Stênio Garcia, que trabalharam também na versão da Excelsior. Mauro Mendonça interpretou em ambas Dom Braz, apesar de em 1963 não ter idade condizente com a da personagem.

Como na versão da Excelsior, houve dificuldades com a produção do cenário:

"Trabalhar com um período pouco apresentado na TV brasileira exige reconstituição cenográfica incomum. A maioria das gravações foi feita ao ar livre e sofreu diversos atrasos com as chuvas em novembro e dezembro.

Além de reconstruir aldeias de índios com o auxílio de alguns caciques, a principal cidade cenográfica, a Vila de São Paulo (sic), foi reproduzida com os materiais originais: sem pedras, usando apenas barro e madeira." 43

A minissérie superou as expectativas da emissora, conseguindo grande audiência. E foi também premiada pela APCA (Associação Paulista dos Críticos de Arte) - categoria

\footnotetext{
${ }^{41}$ Alexandre Maron. "A Muralha é um risco", afirma Daniel Filho. Folha de S. Paulo, 14/12/1999, caderno Ilustrada, p. 4-4.

42 Anna Lee. Índios fazem figuração em minissérie da Globo. Folha de S. Paulo, 30/09/1999, caderno Ilustrada, p.4-4.
} 
Televisão, Grande Prêmio da Crítica e Melhor Ator para Tarcísio Meira. Outro prêmio foi $2^{\circ}$ Grande Prêmio Cinema Brasil, de Petrópolis, como Melhor Série de TV. Também foi vendida para outros países: Chile, Guatemala, Letônia, Moçambique, Nicarágua, Paraguai, Peru, Portugal, República Dominicana e Venezuela. ${ }^{44}$

\section{A trama da minissérie}

A história se passava em São Paulo de Piratininga, no início do século XVII. A jovem portuguesa Beatriz estava vindo para o Brasil, a fim de se casar com seu primo Tiago Olinto, filho de Dom Braz Olinto, homem importante e respeitado em São Paulo. Dom Braz vivia a caçar índios na mata para poder vendê-los como escravos. Da sua tropa faziam parte seus filhos Tiago, Leonel, sua sobrinha Isabel, o índio Apingorá e seu genro Afonso Góis.

Tiago tinha desavenças com o pai, pois achava que eles deveriam procurar ouro e não ficar caçando os índios. Outra razão de discórdia entre pai e filho foi o casamento. Inicialmente, Tiago não parecia entusiasmado com a idéia de se casar com a prima. Como havia poucas mulheres brancas na colônia, Dom Braz mandou buscar uma no reino para seu filho.

Beatriz estava cheia de sonhos e expectativas românticas em relação a Tiago e sua nova vida. Veio acompanhada em sua viagem de Ana Cardoso, uma judia convertida, que chegou ao Brasil com a obrigação de se casar com o irmão de um inquisidor, a fim de salvar a vida de seu pai. E Antônia, uma prostituta do reino, que, por ser mulher branca, veio para a colônia com intuito de encontrar um marido e mudar de vida. Elas vieram acompanhadas do padre Miguel, um jesuíta.

Ana foi recebida na chegada por Dom Guilherme Schetz, comerciante, que a mando de seu noivo, Dom Jerônimo, a hospedou e cuidou de sua viagem a São Paulo. Imediatamente ambos ficaram encantados um com o outro.

Antônia, depois que se desvencilhou de índias e homens abusados, foi escoltada por outro comerciante, Davi Fonseca, ou Davidão, que demonstrou seu interesse por ela.

\footnotetext{
${ }^{43}$ Alexandre Maron. Bandeirantes vão invadir tela da Globo. Folha de S. Paulo, 02/01/2000, caderno TV Folha, p.3.

${ }^{44}$ Dicionário da TV Globo, op. cit. , p.369.
} 
Beatriz foi recebida por Aimbé, mestiço de índio e branco, que vivia a serviço de Dom Braz e Tuiú, um jovem índio escravo. Começaram aí as decepções de Beatriz. Na sua chegada, não foi recebida por seu noivo. Além disso, foi obrigada a realizar uma penosa viagem para subir a serra (a muralha que dá o título à obra) e chegar a São Paulo, onde esperava encontrar acolhimento e riqueza. No entanto, o que encontra é uma cidade deserta, pobre, com pessoas de costumes diferentes dos dela.

A família de Dom Braz vivia na fazenda Lagoa Serena, afastada da cidade. É para lá que Beatriz se dirigiu e encontrou o que seria seu destino: viver a espera dos homens que partiam para a mata, como Mãe Cândida, esposa de Dom Braz, Basília e Rosália, suas filhas e Margarida, a nora, esposa de Leonel. Mulheres de personalidades e forças diferentes.

Dom Braz e sua tropa retornaram e aí começaram os conflitos da família. Tiago gostou de Beatriz, mas guardava um segredo que poderia impedir a relação de ambos. Tiago se relacionava com sua prima Isabel, sem saber que esta na verdade era sua irmã. Isabel estava grávida e mantinha em segredo quem era o pai da criança. Ela mantinha uma forte relação com o índio Apingorá. Leonel e Margarida viviam um casamento de sonhos para aquele mundo. Basília era casada com Afonso, que durante a história, perdeu a memória e passou a viver com os índios.

Rosália, a filha mais nova, apaixonou-se por Bento Coutinho que era um aventureiro, um dos vilões da trama e responsável por grande parte dos sofrimentos da família de Dom Braz. Bento, ao participar de uma tropa de Dom Braz, roubou o mapa de Ribeirão Dourado, um veio de ouro descoberto por Tiago e por direito de Dom Braz.

Enquanto essas relações se davam em Lagoa Serena, na vila de São Paulo, Ana conhecia Dom Jerônimo, seu noivo e algoz. Apaixonada por Dom Guilherme, foi obrigada ao casamento com outro e sofria desesperadamente. Dom Jerônimo descobriu seus sentimentos e a submeteu a torturas e penitências. Ele era o maior vilão da trama.

Antônia despertou o interesse de vários homens, mas demorou em se decidir por Davidão. Acabou sendo uma aliada para Ana e Guilherme.

O padre Miguel acabou discordando de vários princípios de sua ordem em relação à situação do indígena. E acabou se apaixonando por uma índia, chamada Muatira. 
Essas tramas se desenvolveram simultaneamente e as personagens se relacionaram como amigas, ou inimigas. Bento Coutinho e Dom Jerônimo acabaram se aliando em determinado momento para se apossar do Ribeirão Dourado.

Um dos momentos marcantes da trama foi a luta das mulheres de Lagoa Serena com os índios. Antes que se revelasse a paternidade do filho de Isabel, Apingorá foi acusado de ser o pai da criança. Leonel, para se vingar, matou Apingorá e destruiu sua aldeia, o que motivou os índios a atacarem Lagoa Serena.

O outro momento marcante foi a batalha pelo Ribeirão Dourado, na qual morreu Dom Braz.

Vemos que a narrativa teledramatúrgica aproveitou algumas personagens e situações e criou outras: as personagens do núcleo de Ana e do padre Miguel não existiam na obra original. Dom Guilherme não era uma personagem tão heróica e carismática no livro e parecia nutrir interesse por Cristina (que na série é Beatriz). As questões dos índios, dos jesuítas e da Inquisição foram elaboradas para a minissérie.

Algumas personagens apareciam sem destaque e com relações diferenciadas, como Afonso Góis, algumas vezes citado no livro, mas que na minissérie se tornou marido de Basília, que na narrativa original era solteira.

A trama de Antônia também foi modificada: na minissérie possui vários pretendentes, e no livro, ela já vinha prometida para Davidão.

A história da irmandade de Isabel e Tiago também não é clara no livro.

A batalha do Capão da Traição foi substituída pela batalha do Ribeirão Dourado. Devido ao deslocamento de tempo, não se tocou no assunto Guerra dos Emboabas, mas a descrição da batalha no livro de Dinah foi muito semelhante à batalha ficcional por Ribeirão Dourado.

Em muitos pontos, Maria Adelaide foi fiel ao livro de Dinah, especialmente em captar e manter a essência psicológica das personagens. Alguns anacronismos presentes no livro acabaram sendo transferidos para a minissérie.

Devido às licenças poéticas e necessidades de número grande de capítulos e de facilitar o entendimento do telespectador, foram feitas também alterações como o nome das personagens. 
A obra televisiva tem regras de construção diferentes da obra literária, constituindo outra obra:

"É importante ressaltar que, a partir do momento em que ocorre a adaptação para o meio televisivo, uma outra obra é criada. A telenovela passa a constituir outra referência, diferente do romance em termos de recursos, de estrutura e até de conteúdo.

Durante o processo de adaptação, são necessárias alterações e modificações por causa das características próprias do novo meio. Com isso há o alargamento do universo do romance. São criadas e inseridas tramas e personagens que não existem na obra literária para completar as ações e movimentar o contexto da telenovela, a fim de que se possa ter elementos e situações capazes de mantê-la no ar durante vários meses. Não se deve esperar, portanto, que a telenovela apresente exatamente o mesmo conteúdo, narrativa, personagens e situações do livro." 45

Isso explica mudanças de nomes e criação de novas personagens e eventos.

A versão em DVD teve muitas cenas cortadas, o que prejudica um pouco o entendimento da trama ficcional. As questões históricas tratadas não são prejudicadas, possibilitando a quem assiste conhecer, pela ficção, alguns aspectos da Vila de São Paulo de Piratininga. Segundo Maria Adelaide, a edição do DVD foi feita pela diretora Denise Saraceni. ${ }^{46}$

\footnotetext{
${ }^{45}$ Mônica de Moraes Oliveira. Telenovela \& romance: Tocaia Grande na sala de aula. Dissertação de Mestrado. São Paulo: ECA/USP, 1997, p.13.

${ }^{46}$ Entrevista concedida pela autora Maria Adelaide Amaral para esta pesquisa.
} 


\title{
CAPÍTULO II - O PASSADO RECRIADO
}

Este capítulo tem como objetivos: apresentar como o passado foi recriado na narrativa teledramatúrgica, as imagens que permitiram a visualização do passado, destacar o aspecto de gênero - a condição feminina, relacionar outros temas passíveis de serem explorados, e, demonstrar como a historiografia foi apropriada pela autora do roteiro.

\section{O COTIDIANO: SÃO PAULO DE PIRATININGA NO SÉCULO XVII}

Na ficção seriada televisiva um dos elementos mais importantes é uma boa construção de um cotidiano ficcional. Como coloca Maria Lourdes Motter:

\begin{abstract}
"Para que se possa conviver com dezenas de personagens e ler suas trajetórias de vida, seus problemas e entender suas ações com algum interesse, é indispensável que eles nos pareçam reais. Um dos elementos fundamentais para que esse efeito se realize, está, a nosso ver, na estruturação da personagem a partir da instituição de um cotidiano que o prenda, que o ancore no espaço e no tempo. Tecido de reiterações e recorrências, o cotidiano participa na construção da personagem marcando-a por hábitos rotineiros, cuja sucessão demarca sua individualidade, sua existência enquanto ser e lhe garante similitude com o real. Seu cotidiano individual é organizado também em função do cotidiano que se articula na trama geral da narrativa e da qual todos os personagens participam como integrantes desse universo particular." ${ }^{1}$
\end{abstract}

Pela passagem citada, entende-se que em um cotidiano verossímil é necessário a criação de problemas, ações, relacionamentos e conflitos para as personagens. Para se encontrar argumentos para isso, o autor busca elementos na vida real e, no caso da ficção histórica, na própria história.

Entre os aspectos do cotidiano da vila de São Paulo que identificamos na minissérie estão: a pobreza e a escassez de dinheiro e objetos; o descaso da metrópole com São Paulo e seus habitantes; ausência de mulheres brancas; ocupações e autoridades; escravidão indígena como atividade comercial; produtos comercializados; a União Ibérica; relação com as autoridades religiosas e metropolitanas; mobiliário; alimentação; higiene; relações familiares e comerciais, cerimônias sociais e aspectos da religiosidade.

\footnotetext{
${ }^{1}$ Maria Lourdes Motter. Ficção e realidade: a construção do cotidiano na telenovela. São Paulo: Alexa Cultural, Comunicação e Cultura - Ficção Televisiva, 2003, p.32.
} 
Na narrativa da minissérie um dos primeiros aspectos que chamaram a atenção do público telespectador, através de Beatriz, foi a pobreza em São Paulo. Encontrou um local de chão de terra batida, molhada, parecendo barro, animais como porcos soltos na rua, um local despovoado, com uma cruz ao centro, cercada de casas muito simples. A vila era murada para evitar ataques indígenas e seus portões eram abertos para a entrada de habitantes e viajantes. Sua impressão foi revelada em diálogo com Aimbé, reforçado pela imagem:

"Beatriz: São Paulo de Piratininga é isso e nada mais? Aimbé: É isso só dona. Só isso." 2

\section{Imagem não disponível}

\section{para internet.}

Chegada de Beatriz em São Paulo de Piratininga. A decepção ao ver um local desabitado, com poucas casas e pobre.

Ela percebeu os costumes rudes e a vida simples, mas questionou a afirmação de pobreza, em função da fartura de alimentos. Em diálogo com Margarida, caminhando pelo milharal:

"Beatriz: Como podem dizer que são pobres, com tanta fartura de mantimentos?

Margarida: Mas isto é para nosso sustento e para trocarmos pelas coisas que nos faltam. Porque dinheiro, dinheiro mesmo, não há, Beatriz. E também se houvesse, o que haveríamos de comprar?" 3

\footnotetext{
${ }^{2}$ Maria Adelaide Amaral. A Muralha (DVD). Globo Vídeo, 2002. Disco 1 - Capítulo 1.
} 
A escassez não é só de recursos financeiros para compras, mas também de objetos a serem adquiridos. O estranhamento de Beatriz foi muito grande. Mesmo sendo considerada pobre no reino, tanto que teve que aceitar um noivo em terra estranha, por não ter dote, estava acostumada a outra vida.

A questão do dinheiro e da produção foi mostrada em outra cena. Decepcionada com a rejeição de Tiago, Beatriz pediu ao tio dinheiro para voltar ao reino. Dom Braz riu e falou:

"Dom Braz: Beatriz, nossa moeda é o que plantamos e o que colhemos. Em Piratininga não se compra. Troca-se. Portanto, mesmo que eu quisesse mandá-la de volta ao Reino, não teria dinheiro para lhe emprestar." ${ }^{4}$

Também Antônia, outra personagem vinda do reino, estranhou a pobreza. Em diálogo com Davidão, reclamava:

"Antônia: Ai, meu Santo Antônio. Aonde fui jogar a minha âncora sagrada?

Davidão: A vila é pobrezinha, mas tem a vantagem de estar longe dos braços de El Rei.

Antônia: E ele é louco de importar-se com uma porcaria destas?" 5

O diálogo refletia que ao tema da pobreza, somava-se o descaso do rei com a colônia, em especial com os paulistas.

Antônia veio para a colônia em busca de marido. Era prostituta no reino, mas branca, e sua chegada alvoroçou os homens de São Paulo. As cenas com Antônia e seus pretendentes possuíam um tom cômico, que aliviava a tensão e o drama presentes na história através de outras personagens, como Ana e a família de Dom Braz.

Através dos pretendentes de Antônia, apresentavam-se personagens sociais e suas funções do cotidiano da vila na época. Por exemplo, Gonçalo Roiz: “....barbeiro, tira-dentes, físico e cirurgião experimentado e examinado.” Além das suas ocupações, descrevia suas posses: "casa de dois lanços, oito vacas, um cavalo, um casal de perus, um rosário de prata e cinco negros da terra." 6

Outro a se apresentar foi o ouvidor, Bartolomeu Fernandes:

"Bartolomeu: Moro numa casa coberta de telhas e tenho outra alugada por oitocentos réis.

\footnotetext{
${ }^{3}$ Idem.

${ }^{4}$ Disco 1 - Capítulo 2.

${ }^{5}$ Idem.

${ }^{6}$ Idem.
} 
Antônia: Mas isso não dá nem para comprar um penico. (...).

Bartolomeu: Sou ouvidor. Tenho curso de Letras em Coimbra, Os Lusíadas de Camões e um morgadio em Portugal." 7

E o vereador Cristóvão Rabelo, que possuía a única cama da vila de São Paulo de Piratininga, além de:

“...roupas, roupetas, ropetilhas, capas, borzeguins de carneiro, botas de vaqueta, luvas enfeitadas, e um espelho, e muito mais para o asseio e a vaidade de um homem de bem.",

Através dos diálogos foram apresentadas personagens ficcionais, inspiradas em pessoas que viviam na vila na época, exercendo funções de barbeiro, vereador e ouvidor. Isso foi feito de maneira cômica na disputa por Antônia. Cada um quis oferecer mais vantagens através de suas posses e ocupações, colocadas pela minissérie como próprias do cotidiano de então. Nas afirmações de propriedade, houve referências a valores financeiros e vestimentos. Consideramos que destacar as ocupações e autoridades presentes na vila durante a época narrada foi para nossa pesquisa mais importante do que destacar as pessoas, verificando sua real existência no passado, ou em quem cada personagem foi inspirada.

A temática do indígena não foi desenvolvida por Dinah Silveira de Queiroz, sendo um dos acréscimos de Maria Adelaide Amaral para a trama televisiva. Apesar do destaque na minissérie, não foi um dos temas escolhidos por nós para aprofundamento nesta pesquisa. Porém, no cotidiano dos paulistas, estava a atividade de aprisioná-los e vendê-los como escravos, incluindo-se como atividade comercial.

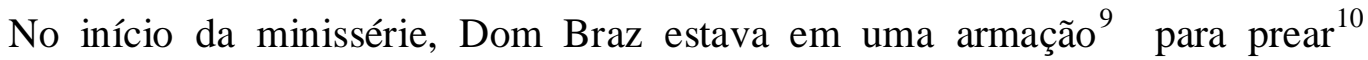
índios, que foram vendidos depois em leilão. A atividade era proibida, porém não era possível impedir. Os preços apresentados variavam entre 9 e 15 mil réis, sendo que um curumim $^{11}$ valia 3 mil réis. Na cena, os índios são humilhados e zombados pelos brancos. O padre Simão, superior jesuíta, chegou com o ouvidor, Bartolomeu, para tentar impedir o leilão:

\footnotetext{
${ }^{7}$ Idem.

${ }^{8}$ Idem.

${ }^{9}$ Empresa que explorava a caça de índios.

${ }^{10}$ Aprisionar.
} 
"Bartolomeu: Eu ordeno que suspendam este leilão em nome de El Rei!

Dom Braz: E o que quer El Rei? Que morramos à míngua, nesta terra abandonada por ele, e por Deus?

Leonel: El Rei está em Madri. Não conhece as nossas aflições.

Bartolomeu: Eu ordeno que libertem esses índios!

Dom Braz: Pois eu ordeno que vosmecê estude as leis, porque é costume e foro dos paulistas se servir da indiarada (sic), devido à pobreza e ao abandono desta capitania.

Padre Simão: Ou vosmecê solta essa gente, ou será excomungado!

Dom Braz: Pensa que eu tenho medo de sua excomunhão? Acima de vosmecê está Deus, que sabe das nossas necessidades." ${ }^{12}$

\section{Imagem não disponível para internet.}

Dom Braz (apontando para os índios) vende indígenas em leilão na fazenda de João Antunes (de costas).

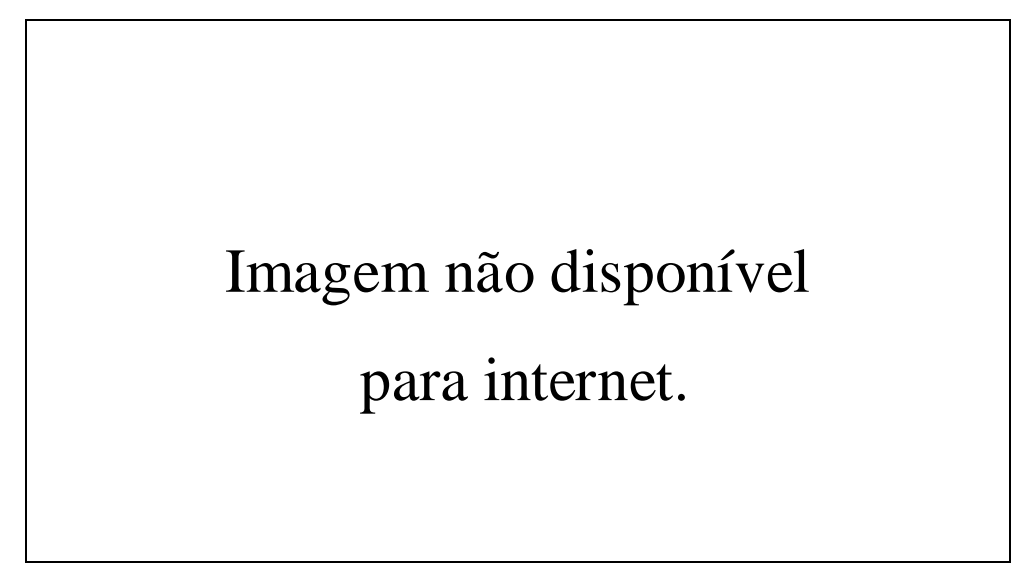

Dom Braz diz o preço de cada "peça".

${ }_{11}^{11}$ Palavra de origem tupi que significa menino. Era como as crianças indígenas eram chamadas.

${ }^{12}$ Maria Adelaide Amaral e outros. op. cit.. Disco 1 -Capítulo 2. 


\section{Imagem não disponível}

para internet.

Padre Simão chega com Dom Bartolomeu, o ouvidor, para impedir o leilão.

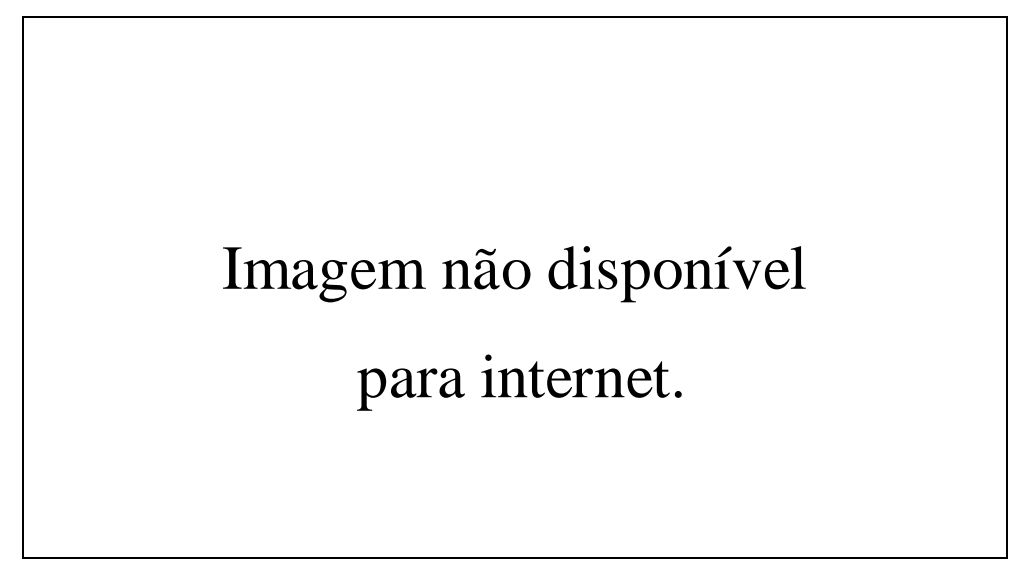

Dom Braz e João Antunes discutem com eles.

\section{Imagem não disponível para internet.}

Da esquerda para direita Tiago, João Antunes e Dom Braz. Tiago não concorda com as atividades do pai, mas não consegue se opor a ele, quando questionado por Padre Simão. 
Dom Braz representava o paulista da época, que desafiava a autoridade do rei e da Igreja em favor de sua sobrevivência. Outra questão apontada é que a história se passava no período da União Ibérica. ${ }^{13}$

Outras atividades comerciais dos paulistas foram indicadas. Logo no desembarque de Beatriz, Ana e Antônia, em Santos, ou São Vicente ${ }^{14}$,quando Guilherme e Davidão conversavam:

"Guilherme: ...embarquem o açúcar e desembarquem o sal.

Davidão: Lisboa não quer nosso açúcar, pois acham que o de Pernambuco é mais barato." 15

Na seqüência, Guilherme dizia que se Lisboa não queria o açúcar, ele seria mandado para Buenos Aires. Além do comércio do açúcar e do sal, o diálogo indicou os problemas com a atividade açucareira. Em Pernambuco houve o desenvolvimento e enriquecimento através dessa atividade. Em São Paulo não prosperou. Também mostrou uma relação de comércio com Buenos Aires, o que contradizia o que se conhece como Pacto Colonial, que proibia a colônia de fazer comércio com outro país que não fosse a metrópole. $^{16}$

O açúcar e o sal eram extremamente valorizados. Dom Jerônimo ao receber Ana, pede sua encomenda a Guilherme e diz a ela que: ..." isso vale ouro nesta terra", "vale mais do que as jóias" que ela trazia. ${ }^{17}$

A marmelada era também comercializada. Antônia aprende a fazer na casa de Bento Coutinho. Com Davidão ela descobre que ele adulterava o produto, usando a fruta-do-lobo. ${ }^{18}$

\footnotetext{
${ }^{13}$ É chamado de União Ibérica o período entre 1580 e 1640, no qual, por razões de sucessão ao trono, Portugal acabou anexado à Espanha. Ver referências em: Ronaldo Vainfas (org.). Dicionário do Brasil Colonial (1500-1808). Rio de Janeiro: Objetiva, 2001, p.570 a 573.

${ }^{14} \mathrm{Cf}$. Afonso de Escragnolle Taunay. São Paulo nos primeiros anos: ensaio da reconstituição social; São Paulo no século XVI: história da vila piratiningana. São Paulo: Paz e Terra, 2003, p. 146, havia comércio pelos dois portos.

${ }^{15}$ Maria Adelaide Amaral. op. cit., Disco 1 - Capítulo 1.

${ }^{16}$ Sobre esse assunto ver: .Alice Piffer Canabrava O comércio português no Rio da Prata (1580-1640). Belo Horizonte; São Paulo : Editora Itatiaia: Editora da Universidade de São Paulo, 1984.

${ }^{17}$ Maria Adelaide Amaral. op. cit., Disco 1 - Capítulo 2.

${ }^{18}$ Arbusto ou árvore de até $5 \mathrm{~m}$, que ocorre no Brasil (AM a GO, MG, SP), com caule ereto, ramos e folhas aculeados, flores azuis, grandes, em cimeiras racemosas escorpióides, e bagas globosas, amarelas, de até $12 \mathrm{~cm}$, comestíveis, de polpa doce é também usada como forragem e por propriedades medicinais; fruteira-de-lobo, fumo-bravo, jubeba, jurubeba-grande, lobeira. Segundo Taunay era usada na falsificação da marmelada em São Paulo no século XVI. Cf. Dicionário eletrônico Houaiss de língua portuguesa 1.0 5a. Também ver: Afonso de Escragnolle Taunay. op. cit. p.142. Maria Adelaide Amaral, Disco 1 Capítulo 2.
} 
Davidão apareceu no Capítulo 1, embarcando produtos como marmelada, farinha de milho e uma cama.

O mobiliário também era muito simples. A minissérie retratou uma mesa de madeira para as refeições da família, bancos para se sentar, esteiras para dormir. Dom Braz possuía uma cadeira. Havia também as redes. O uso da cadeirinha, para transportar pessoas, era um grande luxo.

A alimentação também foi apresentada. Beatriz estranhou a ausência de talheres. Em sua primeira refeição em Lagoa Serena, as mulheres comiam com as mãos. Mãe Cândida diz a ela que em Lagoa Serena não carecia de luxo, nem vaidade, para ela não comparar com o reino. ${ }^{19} \mathrm{Na}$ festa de casamento de Beatriz apareciam os seguintes alimentos: banana, maçã, milho, pão e carne assada na fogueira. ${ }^{20}$

As pessoas apareciam normalmente sujas e suadas, com roupas em farrapos ou rasgadas; os alimentos ficavam expostos e questões de higiene não foram abordadas diretamente, mas, de acordo com as imagens descritas acima, era precária.

No aspecto das relações familiares, havia a família de Dom Braz e o viúvo João Antunes. Entre os que viviam com Dom Braz estavam Aimbé (mestiço, filho do irmão de Dom Braz), os índios Tuiú e Parati, além da criada índia, Genoveva. João Antunes tinha seu filho Vasco. As outras personagens viviam sozinhas: Guilherme (com índios servindo em sua casa), Gonçalo, Bartolomeu, Cristóvão e Bento. Dom Jerônimo vivia com Ana, a empregada Leonor e a índia Muatira. Antônia vivia um tempo com cada pretendente e no final passou a viver com Davidão.

Dom Braz era o patriarca autoritário da família. Sua relação com o filho Tiago era tensa, tanto por ele não aceitar de imediato a noiva Beatriz, como principalmente por querer se dedicar a busca de ouro e não a prear índios. Em cena do Capítulo 2, Tiago foi repreendido pelo pai, pois saiu sem sua autorização e ainda não deu atenção à noiva. $\mathrm{O}$ pai mandou sentar-se ao lado de Beatriz. Ele não quis e Dom Braz o ameaçou com chicote para aprender a respeitar seu pai, sua mãe e sua noiva. Ele se justificou pois está cansado da viagem à vila. Dom Braz, em atitude violenta, fez Tiago se ajoelhar. Mãe Cândida sobriamente apoiou o marido. Toda essa situação deixou Beatriz assustada.

Após esse episódio, Dom Braz pediu que Margarida escrevesse no livro de $\operatorname{assentamentos}^{21}$ :

\footnotetext{
${ }^{19}$ Maria Adelaide Amaral op. cit., Disco 1 - Capítulo 1.

${ }^{20}$ Idem, Disco 2 - Capítulo 4.

${ }^{21}$ Livro de registros.
} 
“ Dom Braz: Neste dia em Lagoa Serena fizeram-se prometidos para tomar a bênção dentro de duas semanas na igreja do Carmo, na vila de São Paulo de Piratininga, meu filho Tiago Olinto e Dona Beatriz Ataíde, que com toda solenidade obrigaram-se, sob minhas vistas, a manter a fé, amor, obrigação entre ambos.

Beatriz: Dom Braz, bem sabeis que ainda há tempo de cancelar nosso compromisso. Nós só temos por trato algumas cartas trocadas.

Dom Braz: Minha filha, tudo que acontece eu ponho nesse livro. Se estiver no livro e não acontecer, é o mesmo que ter acontecido. ${ }^{, 22}$

João Antunes era amigo da família de Dom Braz e fez sociedade com ele para formar uma armação e caçar índios. Também colaborou na batalha pelo Ribeirão Dourado, na qual acabou morto. João tinha um filho legítimo, Vasco, que se enamorou de Beatriz, tornou-se depois noivo de Rosália, mas ficou só no final. Vasco viveu em Salvador e tinha características diferentes dos rapazes de São Paulo. No capítulo 8, João Antunes se envergonhava ao saber que seu filho abandonou Dom Braz, quando ele foi salvar as mulheres da família em Ribeirão Dourado. Depois, a história dá a entender que Vasco foi deserdado pelo pai, em razão de tal comportamento. ${ }^{23}$

Rosália também foi desprezada pela família por se casar com um homem que sua família não aprovava. Ela fugiu para viver com Bento Coutinho. Os pais passaram a considerá-la morta. $^{24}$

Apesar das discórdias com os padres, a religiosidade foi elemento presente na vida das personagens. As missas mostradas foram rezadas em latim. Também foram apresentadas as cerimônias de casamento de Beatriz, Ana e Antônia. ${ }^{25}$ Outra prática mostrada foi a da confissão para comunhão. A religiosidade em casa apareceu na imagem da Virgem, chamada de Madona do Anjo, por Mãe Cândida. Na casa de Dom Jerônimo apareciam vários santos, como São Sebastião. Antônia rezava em uma cena para Santo Antônio. Os índios eram mandados para a catequese, a fim de seguirem a religião dos brancos.

Acima foram citadas as práticas religiosas aceitas e oficiais, porém, entre os índios na aldeia e entre os judeus convertidos, a história era outra. Através da

\footnotetext{
${ }^{22}$ Maria Adelaide Amaral. op. cit., Disco 1 - Capítulo 2.

${ }^{23}$ Idem, Disco 4 - Capítulo 8.

${ }^{24}$ Idem, Disco 2 - Capítulo 5.

${ }^{25}$ O casamento de Beatriz apareceu no Disco 2 - Capítulo 4; o de Ana no DVD 2 - Capítulo 3 e o de Antônia no Disco 4 - Capítulo 9. O casamento era uma cerimônia religiosa de acordo com a Igreja Católica, que também tinha a função cartorial. Rosália não casou com Bento Coutinho porque não foram cumpridas as exigências de "correr os banhos" (aviso e consulta à comunidade sobre algum 
personagem Caraíba ${ }^{26}$, foi retratado o universo místico e religioso do indígena. Ana e Davidão fingiram a conversão e ainda praticavam a sua religião, com leituras e cânticos.

Entre as práticas religiosas e atividades sociais estava a festa de São Lourenço, retratada em procissão, pedidos e representação de auto, escrito por José da Anchieta. Primeiramente, na procissão havia uma pessoa vestida de São Lourenço, pois não havia uma imagem do santo. Crianças indígenas apareciam vestidas de anjos. Havia uma cena de batalha, em moldes medievais, e índios cantando em seus dialetos.

Depois apareciam as personagens fazendo pedidos ao santo. A pessoa vestida de São Lourenço ficava sentada, e uma pessoa de cada vez ajoelhava-se frente a ele. Nesta cena, Mãe Cândida pedia para Tiago se casar com Beatriz e Basília pedia proteção para Afonso. ${ }^{27}$

Padre Miguel apresentou depois o auto, escrito por José de Anchieta, encenado pelos índios em catequese, em dialeto indígena. $\mathrm{O}$ auto acabou não sendo encenado, pois Muatira fugiu do palco, assustada com as pessoas. ${ }^{28}$

Os aspectos principais do cotidiano de São Paulo foram apresentados junto com as personagens, especialmente nos capítulos 1 e 2 do DVD, constituindo a vila e seus costumes rudes, não apenas o cenário da história, mas também uma personagem a ser descoberta.

\section{A CONDIÇÃO FEMININA}

A minissérie retratou mulheres com personalidades distintas. Cada uma consistia em um universo particular de atitudes, opiniões e sonhos. Entre as personagens femininas de maior relevância estavam as mulheres da família de Dom Braz: Beatriz, Mãe Cândida, Basília, Rosália, Margarida e Isabel. Ana, Antônia e Muatira eram outras personagens femininas de destaque. Além delas havia as criadas Leonor e Genoveva.

Nesta parte do trabalho, indicamos a partir da minissérie, alguns aspectos do universo da mulher paulista no período colonial:a solidão em que viviam enquanto seus

impedimento). Ela passou apenas a viver com ele. Cf.:Ronaldo Vainfas (org.). Dicionário do Brasil Colonial (1500-1808), op. cit. ,p.106-109.

26 “...homens especiais na cultura tupi-guarani, capazes de se comunicarem com o mundo dos mortos e os espíritos ancestrais...eram, portanto, grandes pajés. Distinguiam-se do comum dos pajés, simples curandeiros, exatamente por possuírem este dom, segundo as crenças nativas, de se comunicarem com os ancestrais e mesmo encarná-los ..." In: Ronaldo Vainfas (org.). Dicionário do Brasil Colonial (15001808)., op. cit. , p.94.

${ }^{27}$ Maria Adelaide Amaral e outros. op. cit. Disco 1 - Capítulo 2.

${ }^{28}$ Idem, Disco 2 - Capítulo 3. 
homens partiam para o sertão em busca da sobrevivência; a necessidade de trabalharem e serem fortes para manutenção de suas casas: a condição de submissão da mulher indígena e mesmo da mulher branca a certas regras sociais e preconceitos.

Consideramos que o produto cultural minissérie, segue as regras do folhetim tradicional, portanto as tramas amorosas, suas motivações e desdobramentos, alimentam a ficção e a história é apenas o pano de fundo. ${ }^{29}$

Identificamos alguns aspectos romanescos na obra que foi a fonte inspiradora, o romance de Dinah Silveira de Queiroz. Podemos exemplificar com a forma romântica que Cristina idealizou sua vinda para a colônia e seu encontro com o noivo:

“(...). Quantas noites não vira, acordada, na luz da sua idéia, que caminhava enquanto seu corpo ficava inerte de sono - a cena da chegada! Ele, descendo lépido do cavalo e vindo em sua direção, adivinhando-a à espera, e abrindo os braços. Ela abria também os seus, e se aninhava junto do peito tão quente. E tinha até a pretensão de saber como seria o cheiro, o cheiro de suor, de homem do mato, e tinha até a ilusão de que podia sentir de longe a doçura da barba, de seu rosto. (...)., ${ }^{, 30}$

A essência romântica de Cristina foi captada para a construção da personagem Beatriz. Algumas características foram potencializadas: Beatriz nos pareceu ser mais doce, mais generosa e valente do que Cristina. Era uma heroína que lutava pelo que acreditava. Diferente de Cristina, que mergulhou na decepção e teve dificuldade para reagir, Beatriz enfrentou o novo mundo e as adversidades.

No período inicial da colonização havia poucas mulheres brancas na colônia. Dom Braz manda então buscar uma noiva no Reino para seu filho, Tiago, e o casamento é acertado por carta com a prima Beatriz. ${ }^{31}$

Mesmo quando decide partir, seu diálogo com Mãe Cândida e Basília revela docilidade e nobreza sentimentos, ao mesmo tempo que foi forte para contrariar a família:

\footnotetext{
${ }^{29}$ Sobre a relação folhetim/telenovela: "É conhecida a filiação da novela ao romance-folhetim. Vários estudos reconhecem este tipo de narrativa como uma espécie de arquétipo da telenovela; neste sentido a denominação "folhetim eletrônico é sugestiva: ela indica a persistência de uma estrutura literária herdada do século XIX. (...).”In: Renato Ortiz; Silvia Helena Simões Borelli e José Mário Ortiz Ramos. Telenovela: história e produção. $2^{\mathrm{a}}$ ed. São Paulo: Brasiliense, 1991, p.11.

${ }^{30}$ Dinah Silveira de Queiroz. A Muralha. $8^{\text {a }}$ ed. Rio de Janeiro: Record, 2004, p. 93.

${ }^{31}$ Beatriz tem a autorização da Igreja para se casar com o primo, apesar do grau de parentesco.
} 
"Basília: Vosmecê nos abandona na hora que mais precisamos estar unidas Beatriz.

Beatriz: Se para estarmos unidas é preciso aprovar o assassinato de um sacristão, esqueça.

Basília: Vosmecês que vêm do Reino, parece que já chegam nessa terra com ódio de quem nasce aqui.

Beatriz: Eu trazia muito amor, Basília. A maior riqueza de minha bagagem era o que eu trazia aqui. (coloca a mão no peito). ${ }^{32}$

Apesar do estranhamento à nova vida, em diversos momentos, ela demonstrou ser como as mulheres de Lagoa Serena: lutou contra os índios quando a fazenda foi atacada ${ }^{33}$ e foi com as mulheres retomar a posse do Ribeirão Dourado. ${ }^{34}$ No final, parte para o sertão com Tiago, a fim de encontrar ouro na serra de Sabarabuçu. ${ }^{35}$

\section{Imagens não disponíveis para}

\section{internet.}

Beatriz em dois momentos: à esquerda, assim que chega a São Paulo, suja e cansada da viagem; à direita, já em Lagoa Serana, à espera de Tiago.

A maior luta de Beatriz foi a com sua prima Isabel, também apaixonada por Tiago. Isabel foi criada acompanhando o tio, Dom Braz, pelo sertão. Apingorá dizia que ela era o soldado mais valente da tropa de Dom Braz. Ela se vestia como homem, mas muitas vezes se comportava como um animal. Valente e de personalidade forte, mas extremamente rude e amarga, carente, e com dificuldades para lidar com seus sentimentos. Sua forma de ser refletia que se sentia pouco aceita e amada, exceto pelo tio. Convivia muito com os índios e assimilou muito de seus hábitos e comportamentos.

Nua e pintada como uma bugra ${ }^{36}$, "ofereceu-se" para Tiago e engravidou. A condição de mulher grávida e solteira era mal-vista pela família, mais ainda pela

\footnotetext{
${ }^{32}$ Maria Adelaide Amaral e outros. op. cit. Disco 4 - Capítulo 8.

${ }^{33}$ Idem, Disco 3 - Capítulo 6.

${ }^{34}$ Idem, Disco 4 - Capítulo 8.

${ }^{35}$ Idem, Disco 4 - Capítulo 9.

36 Índia.
} 
desconfiança de que o pai fosse Apingorá. Era perfeitamente normal um branco dormir com uma índia, mas inconcebível a mulher branca dormir com um índio, quanto mais engravidar. Em diálogo com Mãe Cândida, ela refletiu seu ressentimento:

“Mãe Cândida: Vosmecê é filha do irmão de Dom Braz, é filha do casamento. Aimbé é filho do mato.

Isabel: O que é meu filho senão filho do mato, Mãe Cândida?

Mãe Cândida: Devia ter vergonha de falar assim do seu bastardo, e mais vergonha ainda de o comparar com Aimbé.

Isabel: $\mathrm{O}$ meu filho vai ter o mesmo destino que Aimbé. Não pertence nem à sala, nem à cozinha. A lugar nenhum.” 37

Apesar de ser mulher branca, era tratada como um dos mestiços. Sempre se sentiu inadequada. Dom Braz refletiu bem o preconceito à sua condição:

"Dom Braz: Quem foi o maldito?

Isabel: Eu não vou dizer para não desgostar mais vosmecê.

Dom Braz: Sua porca! Sua imunda! Que diferença existe entre vosmecê e essas negras que vão para o mato com qualquer macho?

Por que fez isso comigo, Isabel? Vosmecê que eu considerava mais que um filho. Que dor! Que decepção!” ${ }^{38}$

Por uma série de mal-entendidos, Leonel a viu tentando seduzir Apingorá e considerou certo que o índio fosse o pai do filho de Isabel. Num ato impulsivo, para "lavar a honra" da prima, mata Apingorá. ${ }^{39}$

Depois das tragédias, ficou confirmado que Isabel e Tiago eram irmãos. Em nenhum momento ela sentiu prazer em ser mãe. Sentia-se mais ligada a uma onça que cuidava. A Isabel personagem do livro partiu em uma bandeira. A da minissérie teve um final mítico: como uma índia, foi para o meio do mato e se transformou em onça.

\section{Imagem não disponível para internet.}

Isabel, pintava-se como uma bugra.

\footnotetext{
${ }^{37}$ Idem, Disco 2 - Capítulo 5

${ }^{38}$ Idem, Disco 2 - Capítulo 5

${ }^{39}$ Idem.
} 
Mãe Cândida era a matriarca da família. Bastante dura, mas em alguns momentos com grande compreensão. Era um sustentáculo das outras mulheres e quem controlava tudo quando Dom Braz não estava. Era considerada uma grande guerreira e companheira. Comparada às mulheres vindas do reino e até à sua filha mais nova, Rosália, era muito rude e pouco feminina.

A relação dela com Dom Braz talvez seja a mais próxima das relações matrimoniais do período, caracterizando-se por amizade e respeito. Esta era a visão do amor, com o cumprimento de suas obrigações e a aceitação de que o marido, enquanto estava no sertão, não lhe era fiel.

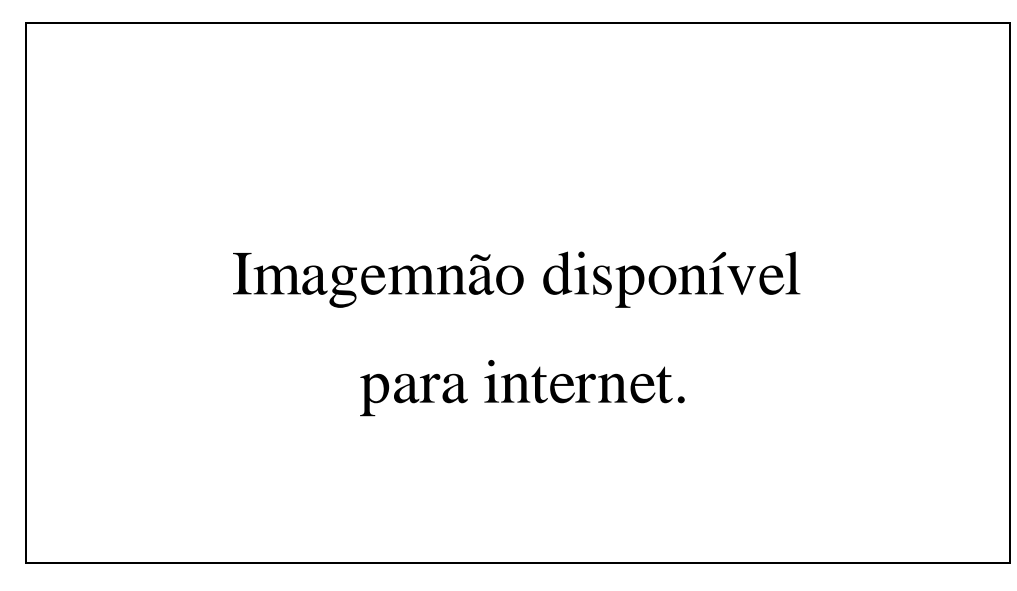

Mãe Cândida

Sua filha mais velha Basília era casada com Afonso Góis. Eles perderam um filho, Pedro, e ela vivia inconformada com isso. Após seu desaparecimento, Afonso foi primeiramente dado como morto e depois reapareceu, sem memória, passando a viver entre os índios. Morreu com os outros homens, na batalha do Ribeirão Dourado. Basília adotou um curumim, que batiza como Pedro Afonso. Era bastante retraída e amarga pelos sofrimentos. No ataque dos índios à Lagoa Serena, levou uma flechada no rosto, que foi costurado por sua mãe, deixando uma enorme cicatriz. Aparentemente, ela estava destinada a ser a herdeira das características e posturas da mãe. 


\section{Imagem não disponível para internet.}

\section{Basília}

Na minissérie, diferentemente do livro, a herança de Mãe Cândida recaiu sobre sua filha mais nova, Rosália, que depois de muito sofrer, acabou cuidando da família. Ela era quase uma criança no início da história. Romântica, se encantou por Bento Coutinho, o inimigo de sua família. Ela se iludiu, achando que ele não prejudicaria seus familiares. Fugiu para se casar com ele e acabou rejeitada pelos pais. Em sua condição de mulher e como filha de Dom Braz, não podia escolher o pretendente.

Rosália acabou descobrindo o caráter duvidoso de Bento e tudo o que ele fez para prejudicar sua família, inclusive as mortes de seu cunhado e seu pai. Mesmo sem ficar com ele, ela permaneceu fiel aos seus sentimentos, não o esquecendo. Bento foi morto por Basília. Rosália assumiu a liderança da família, quando seus irmãos retornam ao sertão.

\section{Imagem não disponível para internet.}


Margarida era doce e frágil, quase como uma flor. Ela era caracterizada de modo diferente das outras mulheres, sempre bonita, limpa, com roupas claras e leves. Assim também foi narrada a personagem da obra literária. Sua ocupação, enquanto os homens estavam no sertão, era escrever versos. As outras mulheres de Lagoa Serena se entregavam ao trabalho. Foi com ela que Beatriz acabou se identificando, pois também não pertencia à Lagoa Serena. Era casada com Leonel, um dos filhos de Dom Braz. No amor deles, apareceram conceitos atuais de fidelidade: Leonel era fiel, e, ele e Margarida se amavam muito. O sonho de Margarida era ter um filho, mas como tinha uma saúde frágil e em virtude de abalos emocionais, acabou morrendo.

O mesmo tipo de amor romântico das personagens foi retratado na obra de Dinah Silveira de Queiroz.

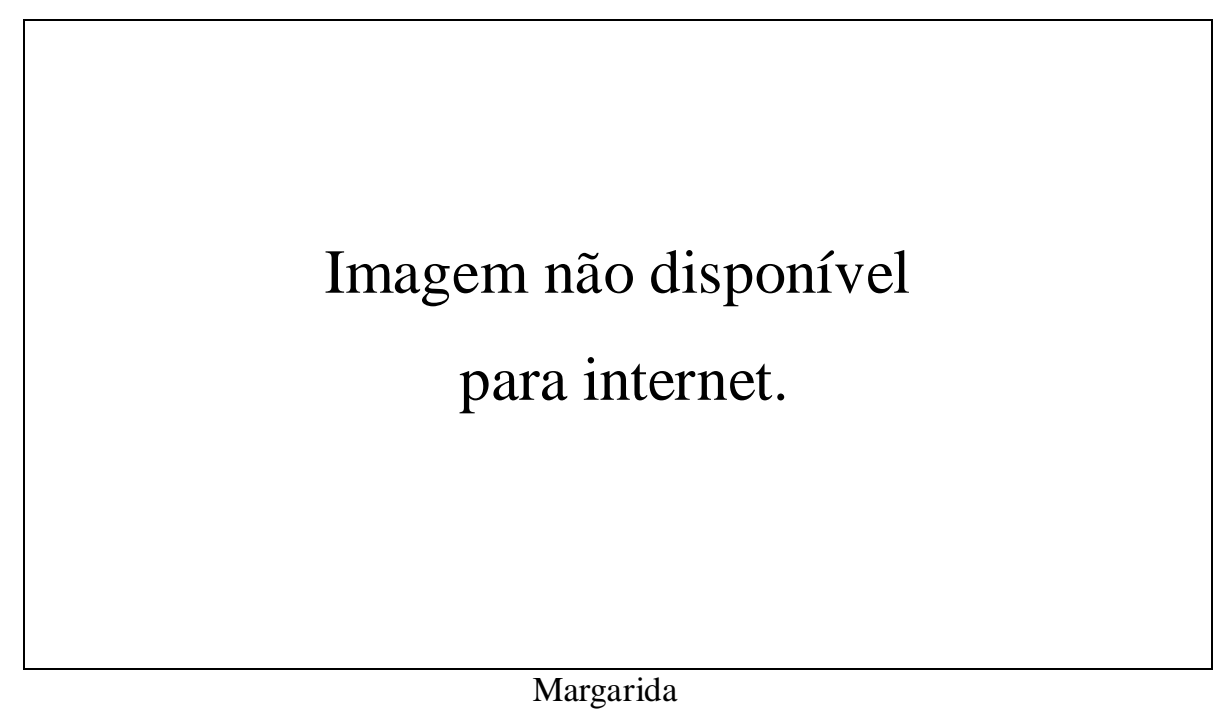

Ana Cardoso, personagem criada para a minissérie, é uma judia que veio para se casar com Dom Jerônimo, em uma troca para salvar a vida de seu pai, preso pela Inquisição. Ana fingiu que abjurou ${ }^{40}$, mas continuava com suas práticas religiosas, em segredo. Ela se apaixonou por Dom Guilherme, mas seu dever a impedia, inicialmente, de aceitar seus sentimentos.

A personagem sofreu muito, não só por sua condição religiosa, mas por ser mulher. Dom Jerônimo era o maior representante da misoginia ${ }^{41}$. Afligia à Ana muito sofrimento, inclusive com procedimentos físicos, como a auto-flagelação. Era tratada

\footnotetext{
${ }^{40}$ Abjurar significa abandonar a religião que ela professava, que era a judaica.

${ }^{41}$ Ódio ou aversão às mulheres.
} 
como uma prisioneira. Em diversas cenas, ela pedia para ir à igreja e ele dizia que não ficava bem para uma mulher sair sozinha, "mesmo que seja em tão santa missão". Em um de seus diálogos:

“Dom Jerônimo: Algo me diz que vosmecê é uma cobra que aninhei em meu peito e que a qualquer momento vai me desferir a picada fatal.

Ana: Vossa Mercê atribui-me um poder, uma força, que eu não tenho.

Dom Jerônimo: Por que eu estou atento, Dona Ana. Porque eu vigio dia e noite para que vosmecê não se afaste dos caminhos da salvação." 42

Além de obrigar Ana a usar o cilício ${ }^{43}$, para sua tortura física, ele também a maltratava emocionalmente. Para não consumar o casamento, levou-a a uma sala cheia de instrumentos de tortura e a mandou escolher um deles para seu martírio:

“ Dom Jerônimo: Às vezes a castidade não é martírio suficiente. Às vezes é preciso adicionar alguma outra mortificação." ${ }^{44}$

Entre os instrumentos de tortura na sala estavam círculos de couro, palmilhas de cravos, coroa de espinhos, chicotes. Esta foi uma das cenas mais fortes. Ana acabou escolhendo a palmilha de cravos e seus pés apareciam sangrando. ${ }^{45}$

Mesmo torturada, Ana respeitava seu dever, achando que estava salvando a vida de seu pai e só abandonou Dom Jerônimo quando descobriu que o seu sacrifício era em vão, pois seu pai já estava morto.

O ódio de Dom Jerônimo era tamanho, que no final ele assumiu o papel de inquisidor, e quiz condená-la à fogueira, junto com àqueles que a ajudaram. ${ }^{46}$

\footnotetext{
${ }^{42}$ Maria Adelaide Amaral. op. cit. Disco 2 - Capítulo 3.

${ }^{43}$ Cinto ou cordão eriçado de cerdas ou correntes de ferro, cheio de pontas, com que os penitentes cingem o corpo diretamente sobre a pele.

${ }^{44}$ Maria Adelaide Amaral. op. cit., Disco 2 - Capítulo 5.

${ }^{45}$ Idem.

${ }^{46}$ Idem, Disco 4 - Capítulo 9.
} 


\section{Imagem não disponível para internet.}

Ana

A outra mulher de destaque foi Antônia, prostituta no reino e que, devido à falta de mulheres, veio para a colônia a mando do rei, para arrumar marido. E arrumou vários pretendentes. Entre uma passagem e outra de convivência com cada um deles, acabou se casando com Davidão. As cenas de Antônia e seus pretendentes contêm certo humor, que aliviava a tensão e drama geral.

Quanto à falta de mulheres, diz:

“ Se eu soubesse que tinha tanta precisão de mulheres nesta terra, eu teria trazido minhas colegas de Ribeira das Naus." $" 47$

Apesar de aceita por muitos, também sofria preconceito, por parte de algumas pessoas:

“ Dom Jerônimo: Vossa Reverência não devia permitir certo tipo de mulher dentro da nossa igreja.

Padre Simão: Dom Jerônimo, o próprio padre Manoel da Nóbrega pediu à Coroa que mandasse para cá todas as mulheres brancas. Órfãs, viúvas, e até mesmo as de vida errada." 48

${ }^{47}$ Maria Adelaide Amaral. op. cit., Disco 1 - Capítulo 2.
${ }^{48}$ Idem. 
A personagem Antônia era alegre e espontânea, sem preocupações com as aparências e convenções sociais. Destacava-se da tristeza de Ana, do romantismo e inexperiência de Beatriz, da amargura e rigidez de Mãe Cândida e Basília.

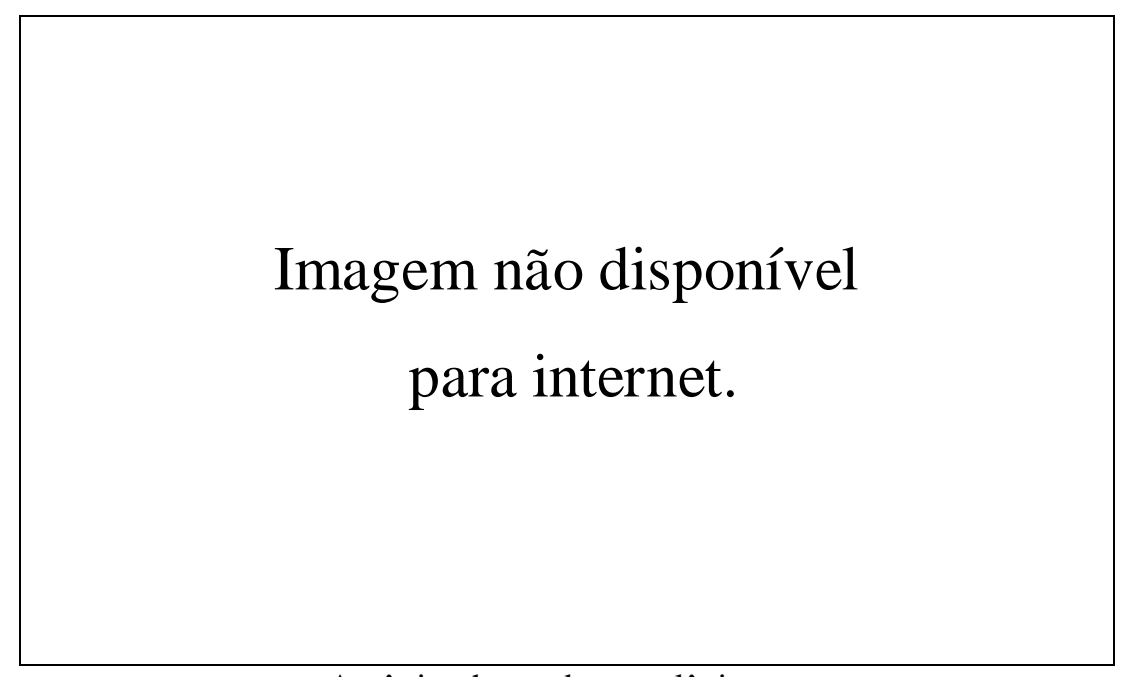

Antônia, chegando na colônia.

Também pode ser considerada uma personagem anacrônica, apesar de certas liberdades que sua condição de ex-prostituta e "mulher solteira" ${ }^{49}$ podiam lhe permitir, já que pretendia se casar de acordo com as normas vigentes.

A personagem Joana Antônia, que serviu de inspiração para a minissérie pareceu-nos ser mais condizente com a época, vindo já comprometida e mantendo uma postura considerada respeitável ao chegar à nova terra.

Outra personagem feminina de destaque foi Muatira, índia caçada em uma armação de Dom Braz e que acabou como escrava na casa de Dom Jerônimo, servindo de criada e objeto sexual. Aparentemente, ele não se relacionava com ela, mas gostava de vê-la e tocá-la, passando a mão pelo corpo da índia com conotação claramente sexual. Também a obrigava a chicoteá-lo, sentindo um prazer doentio neste martírio.

\footnotetext{
${ }^{49}$ Segundo Ronaldo Vainfas, “(...). Solteira era a mulher desimpedida, livre, sem proteção de família ou marido, passível de envolver-se em quaisquer relações amorosas e sexuais. (...).”. Não tinha o mesmo
} 
Muatira participava da catequese na igreja do Colégio. Era aluna de Padre Miguel e se apaixonou por ele. O padre correspondia aos sentimentos, o que causou grande crise, levando-o a se afastar da Ordem. Muatira foi contaminada pelo padre, com uma doença que não foi especificada na versão do DVD e morreu. A condição da mulher indígena foi mostrada através dela, que também sofreu uma tentativa de estupro, na frente de seu filho. ${ }^{50}$

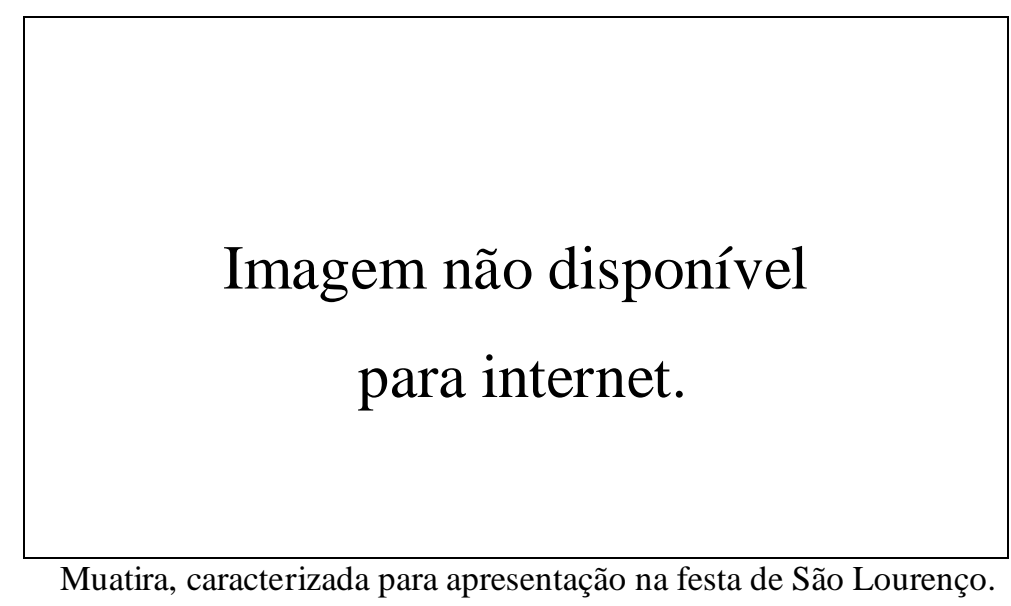

Havia na história duas criadas, em condições diferentes. Genoveva era uma índia, criada da família de Dom Braz e cuidava de todos em Lagoa Serena. Leonor era uma criada branca, na casa de Dom Jerônimo. Era cúmplice de suas maldades e, como seu patrão, tinha uma visão distorcida do mundo e da religião. Gostava de Bento Coutinho, com quem mantinha uma relação íntima, Tinha uma postura hipócrita, pois condenava Ana e outras mulheres por causa de seus relacionamentos.

significado de hoje. Ver: Ronaldo Vainfas. Trópico dos pecados: moral, sexualidade e Inquisição no Brasil. Rio de Janeiro: Campus, 1989, p. 60.

${ }^{50}$ Idem, Disco 1 - Capítulo 1. 


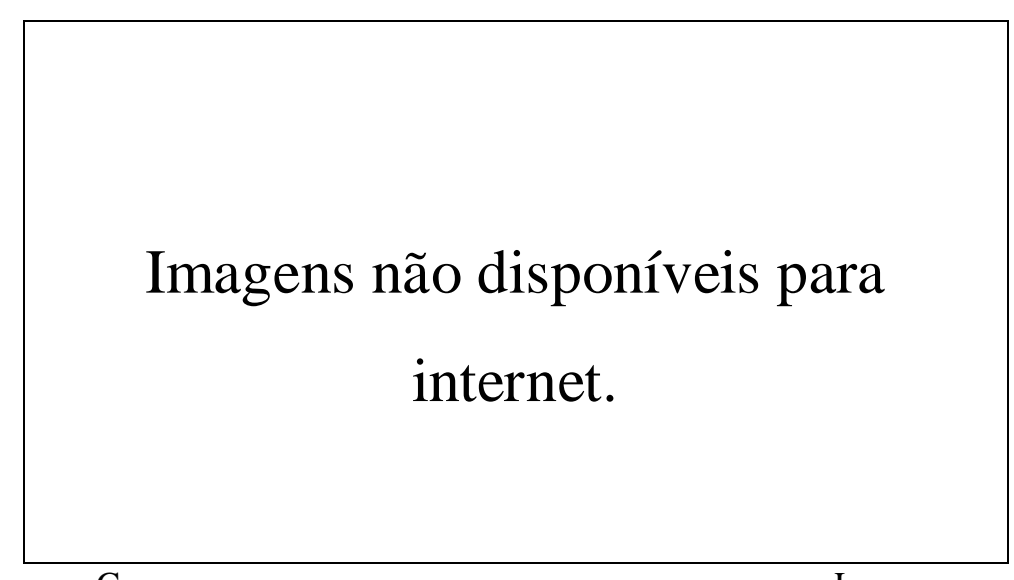

Genoveva Leonor

A imagem da mulher que apareceu na narrativa televisiva foi bastante romanceada: havia heroínas e sofredoras, transgressoras e vilãs. Porém, identificamos alguns elementos presentes nas figuras femininas na minissérie, que permitem a compreensão do papel da mulher no mundo colonial paulista. Também consideramos que na construção das tramas amorosas e no comportamento feminino para os relacionamentos aparecem os maiores anacronismos, pois há clara identificação com o romantismo e aspirações contemporâneas, como, por exemplo, o conceito de fidelidade e o de casamento por amor.

\section{OUTROS TEMAS}

Ao ver repetidas vezes os DVDs e realizarmos a leitura de seu conteúdo, identificamos outros tantos temas que poderiam ser desenvolvidos, como fizemos com o cotidiano e a condição feminina, tais como:

\section{ADMINISTRAÇÃO}

- União Ibérica

- A relação com Coroa e a fiscalização da descoberta de riquezas

- A questão de leis em São Paulo de Piratininga - vila sem guarda e sem cadeia

\section{ECONOMIA}

- Pobreza dos portugueses e a ilusão de riqueza e paraíso nas terras da colônia

- Escravidão do indígena pelo branco e do índio pelo índio 
- Busca por ouro e por outras riquezas

- Dois objetivos das bandeiras: escravizar índios; busca por ouro

- Trabalho feminino

\section{SOCIEDADE}

- Escravidão do indígena pelo branco e do índio pelo índio

- Escassez de mulheres brancas (aceitação de prostitutas) / miscigenação

- Formas de casamento: dever, obrigação, interesses, preconceito (miscigenação), etc

- Relações familiares, tais como entre pais e filhos; maridos e esposas; agregados; filhos bastardos, etc

- Exploração do indígena: abuso sexual, escravização para o trabalho

- Prostituição

- Papel feminino

- Papel masculino

\section{CULTURA}

- Poder da Igreja Católica

- Relatividade dos valores cristãos na expansão da Cristandade

- Imaginário sobre perigos e feitiços nas terras descobertas

- Costumes regulados pela cristandade

- Conversão: de judeus em cristãos; índios em cristãos

- Uso do Tupi

- Religiosidade indígena

- Catequese e alfabetização

- Jesuítas

- Judaísmo

- Inquisição

\section{A HISTORIOGRAFIA TRANSFORMADA EM FONTE}

Pretendemos comentar algumas das fontes históricas e historiográficas utilizadas pela autora da minissérie. Não nos propusemos a fazer esta pesquisa para questionar as 
informações históricas passadas através de veículo de comunicação de massa. Nem é uma discussão historiográfica sobre os assuntos abordados ou o período. Não tem o objetivo de negar ou confirmar a pesquisa realizada para a minissérie.

Nossa intenção é indicar algumas informações históricas e leituras da historiografia, que possivelmente foram utilizadas como fontes de pesquisa, e, que ganharam imagem e movimento através do universo ficcional da televisão.

Não tivemos acesso a toda a pesquisa inicial realizada pela autora e com a dificuldade de reconstituirmos com fidelidade esse percurso, optamos, a partir das referências dadas em entrevista e as informações da minissérie, em selecionar algumas obras da historiografia.

A minissérie explorou muito a imagem de homens e mulheres corajosos e empreendedores, apesar da pobreza e das adversidades que viviam. A necessidade de sobrevivência explica as posturas. A relação com o indígena também foi bastante retratada, entre a escravização, miscigenação de raças e costumes.

\section{O tempo da narrativa televisiva}

O projeto inicial pretendia retratar o século XVI. O livro de Dinah Silveira de Queiroz, que deveria ser a principal fonte de inspiração, transcorria no início do século XVIII e a minissérie no século XVII. Como resolver a questão do tempo para analisar a minissérie? Quais obras exatamente foram usadas?

O período retratado na minissérie é o início do século XVII, sem referências explícitas ao ano, ou em quantos anos se passa a história. ${ }^{51}$ Cruzando algumas das informações podemos presumir que são os anos iniciais do século, pois houve referências a visita do Governador Geral, Dom Diogo, que pode ser Diogo Botelho, que chegou ao Brasil em 1602. ${ }^{52}$ A história provavelmente se passou em período de três a cinco anos, deduzidos a partir dos períodos de gestação, nascimento e crescimento de crianças, filhas das personagens Isabel e Beatriz com Tiago.

\footnotetext{
${ }^{51}$ Em entrevista para esta pesquisa, Maria Adelaide Amaral indicou a data de 1612, porém na versão em DVD apareceu apenas como referência o início do século XVII.

52 Afonso de Escragnolle Taunay. op.cit. p.419. As cenas do Governador Geral aparecem no Disco $4-$ Capítulo 8.
} 


\title{
As fontes historiográficas
}

Conseguimos identificar através de trechos que são citações literais ou quase literais de alguns trabalhos que certamente foram consultados e utilizados como fontes de informação.

Entre as fontes claramente utilizadas na pesquisa da minissérie estão as Cartas dos jesuitas, editadas por Serafim Leite; Atas da Câmara Municipal de São Paulo; e algumas referências foram obtidas em obras de Alcântara Machado, Sérgio Buarque, Taunay, Ernani Silva Bruno, Ronaldo Vainfas. ${ }^{53}$

Certamente um dos autores consultados foi Afonso de Taunay, um dos mais importantes nomes da historiografia sobre São Paulo:

\begin{abstract}
"O mais produtivo e apaixonado historiador da Cidade consolida nas páginas de seus livros a imagem do bandeirante corajoso, empreendedor, indianizado nos costumes, cruel até a perversidade, mas explorador e conquistador do Sudeste, Sul e Centro Oeste do país. Orgulhoso do sangue indígena, mas exigente dos privilégios políticos e sociais de súdito português. Ostentando a fé cristã e a bandeira de conquistador europeu, mas usando de práticas e costumes índios, desafiava bispos e governadores que o menosprezavam com a fama de salteador e bandido homiziado. Taunay foi um dos consolidadores do mito bandeirante, que tão bem serviu à hegemonia paulista na Primeira República, quando comprovava, através da história, uma espécie de direito natural à liderança do país. ${ }^{, 54}$
\end{abstract}

No texto de Laima Mesgravis sobre a São Paulo que Taunay pesquisou, já encontramos alguns pontos em comum com o que a minissérie retratou, como a pobreza da vila, a coragem dos homens e mulheres, as relações com os jesuítas, a catequização dos indígenas e até mesmo o conflito com as autoridades legais - ouvidor e padre, no epísódio do leilão de índios aprisionados por bandeira.

\footnotetext{
${ }^{53}$ Serafim Leite. Cartas dos primeiros Jesuítas do Brasil. Comissão do IV Centenário da Cidade de São Paulo, 1954, Vol.I 1538-1553, Vol. II 1553-1558, Vol. III. 1558-1563; Atas da Câmara de São Paulo. São Paulo: A Câmara, 1562-1700; Alcântara Machado. Vida e morte do bandeirante. São Paulo: Governo do Estado, 1978; Sérgio Buarque de Holanda. Caminhos e fronteiras. São Paulo: Companhia das Letras, 1994; Idem, Monções. $3^{\text {a }}$ ed. ampl. São Paulo: Brasiliense, 1990; Afonso de Escragnolle Taunay. op. cit. ; Ernani Silva Bruno. História e tradições da cidade de São Paulo. 3 vol. Rio de Janeiro: Livraria José Olympio Editora, 1953; Ronaldo Vainfas.op.cit.. Alguns autores foram citados por Maria Adelaide em entrevista ao jornal Folha de S. Paulo e outros em entrevista para esta pesquisa. A escolha dos títulos foi feita a partir da nossa pesquisa.

54 Laima Mesgravis. Afonso de Escragnolle Taunay, o historiador de São Paulo. In: Afonso de Escragnolle Taunay. op. cit, p.8.
} 
Para comprovar as afirmações da historiadora citada, buscamos as obras de Taunay que são dedicadas ao período, São Paulo nos primeiros anos: ensaio da reconstituição social e São Paulo no século XVI: história da vila piratiningana. Como a ação se passa no início do século XVII, encontram-se apresentados vários aspectos de finais do século XVI, estudados por Taunay.

Outro motivo é que o historiador utilizou nessas obras a mesma documentação citada por Maria Adelaide Amaral, as Atas da Câmara e as Cartas dos Jesuítas.

A penosa viagem de Beatriz encontrou amparo na descrição do Caminho do Mar de Taunay:

"No trilho augusto, cortado de resvaladouros, homens e animais freqüentemente arriscam a vida. Era o tempo em que a serra se galgava com o auxílio das mãos - e quiçá dos dentes - na, expressão pitoresca de velho cronista que a subira agarrado às hastes dos arbustos, num dos mais penosos exercícios de alpinismo." 55

A pobreza da vida no planalto foi relatada, porém as personagens Beatriz, bem como sua inspiradora na literatura, Cristina, possuíam visões exageradas, talvez para marcar bem as diferenças entre reinóis e paulistas. Pelos inventários do século XVI e meados do XVII, podia-se observar a pobreza em bens materiais, mesmo entre pessoas de prol. ${ }^{56}$ As afirmações sobre a circulação monetária foram localizadas em Taunay, fundamentado nas Atas da Câmara:

"Moeda era coisa que quase não existia na Vila. O dinheiro da terra vem a ser 'mantimentos e carnes e cera, e couros, e gado, bois e vacas e porcos, porquanto não há outra fazenda, alegava a Câmara de 1575 ao fechar um contrato."

Ocorreu o mesmo quanto a cargos, ocupações e ofícios. A personagem Gonçalo Roiz deve ter sido criada fundamentada no historiador, que afirmava que apenas em 1597 se instalava o primeiro serviço-médico sanitário, com a nomeação de Antônio Roiz como juiz do ofício dos físicos. Na minissérie, a personagem Gonçalo exerce essa função. Em Taunay encontramos as expressões usadas no diálogo de apresentação da personagem na minissérie: “...barbeiro, homem experimentado e examinado. (...)",58, conforme a descrição das Atas.

\footnotetext{
${ }_{55}^{55}$ Afonso de Escragnolle Taunay. op. cit., 2003, p.175.

${ }^{56}$ Idem, p.156.

${ }^{57} \mathrm{idem}$, , p. 91 .

${ }^{58}$ Idem, p. 129.
} 
O exemplo acima nos permitiu perceber a articulação da ficção com os dados históricos. Houve a inspiração, mas não a obrigação de retratar a personagem tal qual a figura histórica. As citações de curandeiros e jesuítas como curadores também possuíam coerência: havia a presença dessas figuras na vila, pois até 1597, e mesmo depois, foram comuns tais práticas, sendo as pessoas chamadas para curar os doentes.

Mesmo explorando as fontes históricas e historiográficas, a minissérie não apresentou toda a complexidade de ofícios da época, como sapateiros, alfaiates, tecelões, ferreiros, carpinteiros, entre outros. ${ }^{59}$

As principais atividades retratadas na minissérie estavam ligadas ao comércio. $\mathrm{E}$ uma das atividades comerciais dos paulistas entre os séculos XVI e XVII era o apresamento e escravização do indígena, o que gerava conflitos com os jesuítas. Segundo Taunay, os padres obtiveram uma lei da metrópole, proibindo o aprisionamento dos índios em "todo e qualquer caso". Porém, isso não era cumprido e no século XVII, a feição escravista era mais acentuada, gerando graves conflitos com os jesuítas. $^{60}$

Dentre os produtos comercializados foram citados o sal, que era exclusivamente importado $^{61}$ e a marmelada, que era o principal produto de exportação do planalto paulista.

A minissérie também indicou o comércio do açúcar, porém não explorou como este produto foi importante para a economia colonial, nem que o fato de não prosperar em São Paulo, influenciava na sua pobreza:

"Não havia em São Paulo fortunas, porque o planalto não produzia açúcar, gênero de eldorado, ao qual deviam pernambucanos e baianos sua opulência...,

Quanto ao mobiliário:

"Que poderia existir nas casas paulistanas quinhentistas? Toscos bancos e catres, mesas e escabelos como mobília, rudes arcas mal ajustadas, onde se guardava a pouca roupa da família...,

\footnotetext{
${ }^{59}$ Idem, p.132-138.

${ }^{60}$ Idem, p. 357.

${ }^{61}$ Idem, p. 172 .

${ }^{62}$ Idem, p. 156.

${ }^{63}$ Idem, p. 158
} 
A religiosidade foi outro aspecto mostrado pela minissérie. Em Taunay, encontramos os argumentos para as disputas entre paulistas e jesuítas - o uso da mãode-obra indígena que para os religiosos devia ficar nos aldeamentos para a catequese. Há também indicação de outras funções que os religiosos exerceram como as funções de médico. ${ }^{64}$

Taunay ofereceu algumas referências sobre as mulheres dessa época. Não tanto aos seus hábitos e costumes cotidianos, mas sobre as famílias a que pertenciam ${ }^{65}$ e a quantidade de mulheres realmente brancas na capitania na época. ${ }^{66}$

A introdução do autor às duas obras data de 1919 e a edição, em França, data de 1920 e 1921.

Sobre sua produção e contribuição há uma numerosa bibliografia, que é contraditória: favorável a seus posicionamentos ou desfavorável. Desde a década de oitenta do século XX, sua obra está classificada como uma das 'criadoras da tradição paulista'.

O sentimento de "patriotismo paulista" e "orgulho de linhagem" que aparecem em todas as versões de A Muralha, provavelmente sofreram influência de historiadores da primeira metade do século XX, como Afonso de Taunay, Alfredo Ellis Jr. e Alcântara Machado. ${ }^{67}$

A imagem construída por essa historiografia acabou sendo extremamente difundida, conforme escreve Katia Abud em seu estudo sobre a construção da imagem do bandeirante:

"O conhecimento histórico produzido, enquanto matriz, por aqueles historiadores foi reproduzido em incontáveis obras de autores menores, em obras de ficção, na literatura didática de nível médio e por meios de divulgação com número menos reduzido de receptores.(...)",68

Em nota, a historiadora realça:

"A literatura aproveitou o tema do bandeirantismo e da simbologia paulista em várias obras, como em A Muralha, de Dinah Silveira de Queiroz e Os Ossos do Barão, de Jorge de Andrade. Estas duas foram transformadas em novelas para a

\footnotetext{
${ }^{64}$ Idem, p. 237.

${ }^{65}$ Idem, p. 393 e 394.

${ }^{66}$ Idem, p.388 a 390.

${ }^{67}$ Katia Maria Abud. O sangue intimorato e as nobilíssimas tradições - a construção de um símbolo paulista: o bandeirante. Tese de Doutorado em História Social. São Paulo:FFLCH/USP (Departamento de História), 1985, p.138.

${ }^{68}$ Idem, p. 180.
} 
televisão, e ajudaram a disseminar a idéia de bandeirante que os historiadores de São Paulo tinham formado." ${ }^{69}$

Outro historiador utilizado como fonte na pesquisa para a construção da narrativa teledramatúrgica foi Sérgio Buarque de Holanda.

Podemos considerar que o estilo de Taunay é mais favorável ao trabalho do ficcionista. Oferece grande quantidade de informações, com muitos detalhes, e nem sempre é possível diferenciar o que é texto do autor de transcrições de documentos.

Sérgio Buarque oferece uma reflexão mais complexa para o historiador, por sua pesquisa aprofundada e análise compreensiva. Mas o que sua obra pode oferecer para um trabalho ficcional? Um outro tipo de informação que, em nosso entender, pode ter sido considerada na elaboração das imagens do cotidiano nos cenários e figurinos. Sem citações explícitas presentes no diálogo ficcional, suas contribuições estão implícitas na imagem que constrói do bandeirante e da sua relação com o meio e o nativo.

Segundo Ilana Blaj, sobre a obra de Sérgio Buarque:

"O percurso do paulista em seus múltiplos caminhos e fronteiras, o cotidiano e a cultura material construídos nascem da necessidade do apresamento do gentio da terra, fazem-se pela introjeção do seu saber e se modificam para tentar burlar suas estratégias e escapar de seus ataques." 70

O perfil rude e primitivo do paulista retratado na minissérie não é gratuito e encontra apoio na visão de Sérgio Buarque:

"Ainda aqui, bem apurado, é um aspecto da influência indígena que insiste em sobreviver em terra onde foram assíduas a comunicação e a mestiçagem com o gentio. Influência que viria animar, senão tornar possíveis, as grandes empresas bandeirantes. Sabemos como era manifesta nesses conquistadores a marca do chamado selvagem, da raça conquistada. Em seu caso ela não representa uma herança desprezível e que deva ser dissipada ou oculta, não é um traço negativo e que cumpre superar; constitui, ao contrário, elemento fecundo e positivo, capaz de estabelecer poderosos vínculos entre o invasor e a nova terra. $\mathrm{O}$ retrocesso a condições mais primitivas, a cada novo contato com a selva e com habitante da selva, é uma etapa necessária nesse feliz processo de aclimação. Sem ela não poderíamos conceber facilmente muitos daqueles sertanejos audazes, que chegaram a aclamar um rei de sua casta e dos quais dizia certo governador português que formavam uma república de per si, desdenhosos das leis humanas e divinas."

\footnotetext{
${ }^{69}$ Idem, ver nota 110 .

${ }^{70}$ Ilana Blaj. Sérgio Buarque de Holanda: historiador da cultura material. In: Antonio Candido. (org.) Sérgio Buarque de Holanda e o Brasil. São Paulo: Editora Fundação Perseu Abramo, 1998, p.45.
} 
O embrutecimento é uma forma de sobrevivência, porém suas causas são indicadas de maneira implícita na minissérie. O paulista se embrutece para sobreviver às adversidades e é julgado, pela heroína, em seu caráter, hábitos e costumes, na narrativa televisiva. A fim de dar elementos para a ficção, a oposição de Beatriz ao paulista é maniqueísta, pois este é, a seus olhos, em determinados momentos, um vilão. Contudo, ele pode ser o herói em relação a outras personagens, como Dom Jerônimo e Bento Coutinho.

Das obras de Sérgio Buarque de Holanda escolhemos Caminhos e Fronteiras. Este livro foi publicado pela primeira vez em 1957, dando um sentido unitário a escritos do autor, ligado a outra obra também sobre o bandeirismo, Monções. ${ }^{72}$

Nos textos de Sérgio Buarque há informações sobre o uso de armas, que aparecem integradas na minissérie, porém sem explicações sobre seu uso. ${ }^{73}$ Alguns outros aspectos que aparecem no livro, na mesma forma: o uso de calçados; a existência de animais, como os porcos e os cavalos, e o uso da rede.

Um dos aspectos do cotidiano apresentado e já comentado é o da exportação da farinha de milho. ${ }^{74}$ Sérgio Buarque fala sobre uma "civilização do milho" e os motivos do desenvolvimento deste cultivo. ${ }^{75}$

\footnotetext{
${ }^{71}$ Sérgio Buarque de Holanda. Caminhos e fronteiras. op. cit., p.21.

72 Sérgio Buarque de Holanda. Monções. op.cit.

${ }^{73}$ Ver esp. capítulo sobre Caça e pesca. In: Sérgio Buarque de Holanda. Caminhos e fronteiras, op.cit., p.60 a 73 .

${ }^{74}$ Davidão embarca entre outros produtos farinha de milho. In: Maria Adelaide Amaral e outros. op. cit.. Disco 1 - Capítulo 1.

${ }^{75}$ Sérgio Buarque de Holanda. Caminhos e fronteiras, op. cit., p. 181 a 189.
} 


\section{Imagem não disponível para internet.}

Cenas de Beatriz e Margarida no milharal.

Imagem não disponível para internet. 
No que diz respeito à cultura material e atividades comerciais podemos encontrar em Sérgio Buarque referências sobre fiação e tear, porém o historiador adverte que essa documentação é insuficiente para analisar seu funcionamento em determinadas épocas:

"Em antigos inventários paulistas, particularmente os dos séculos XVI e XVII, podem apurar-se dados avulsos acerca da fiação doméstica de algodão e lã, durante a era colonial. Sobre os modos de se obter ou negociar o produto, as diferentes fases de sua elaboração, os preços que sucessivamente lhe correspondem, os maquinismos adotados, encontram-se nesses, e, em alguns outros documentos da mesma época, informações que podem ser utilizadas com proveito pelo historiador. Informações que, só por si, já permitem compor um quadro instrutivo do que significou durante longo tempo, entre nós, essa importante indústria caseira." $" 76$

A minissérie não faz referência verbal a esse tipo de atividade, porém no decorrer da história, as mulheres de Lagoa Serena aparecem em diversos momentos dedicadas à fiação, como mostra a imagem a seguir.

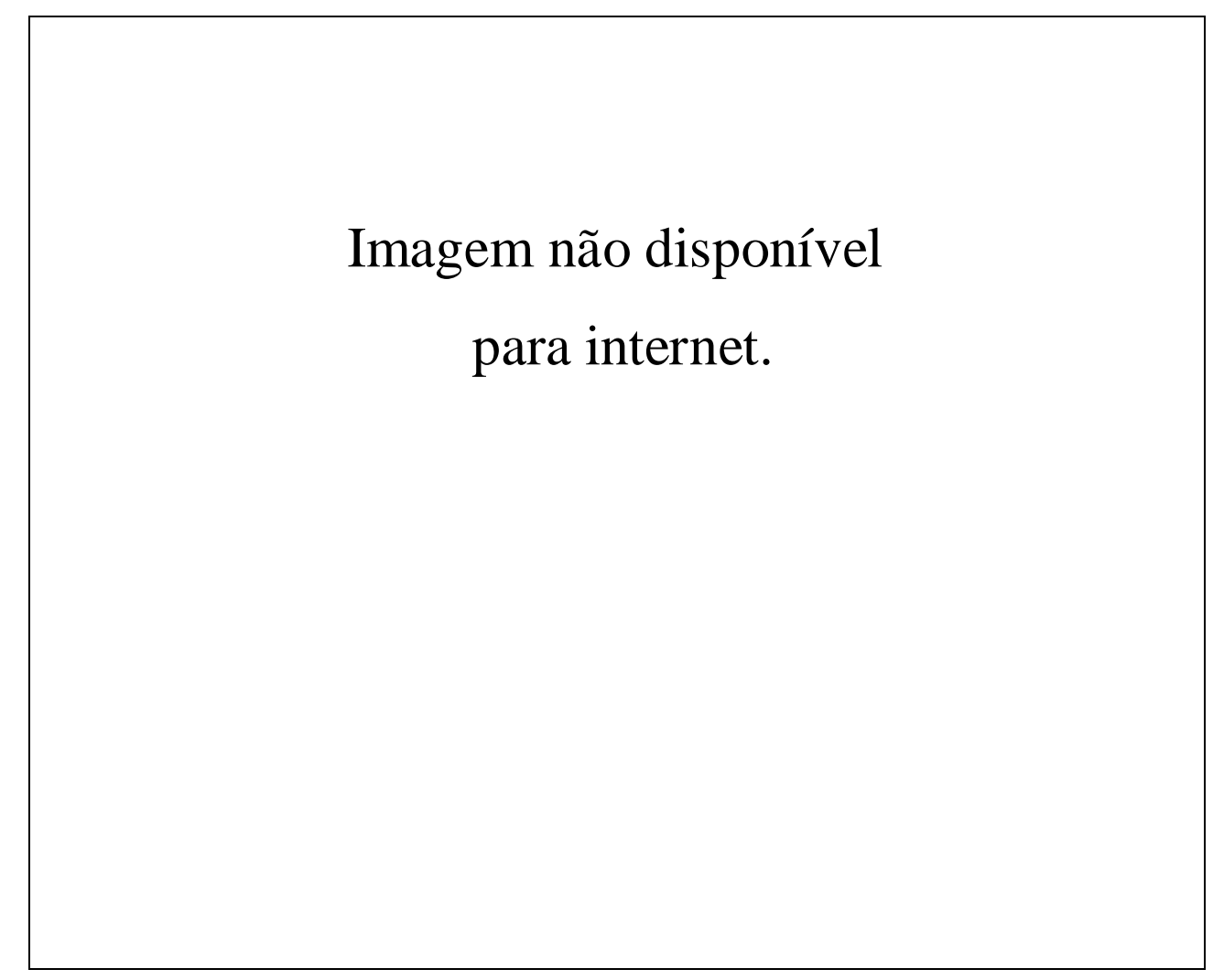

\footnotetext{
${ }^{76}$ Idem, p.221 e 222.
} 
Outras informações dos historiadores já citados no texto também foram aproveitadas em aspectos do cotidiano. Em relação às mulheres, particularmente na história de Ana, podemos encontrar referências no trabalho de Ronaldo Vainfas, Trópico dos pecados, que trata de moral e sexualidade no Brasil entre os séculos XVI e XVII. ${ }^{77}$ Ana teve toda sua história marcada pelo fanatismo de Dom Jerônimo. Ele a amava, odiando, pois sentia ódio das mulheres, a seu ver, um símbolo do pecado. A construção dessas personagens parece-nos ter sido inspirada em algumas informações de Vainfas. Por exemplo:

"No limiar do século XVI, estaríamos, portanto, diante de um complexo processo de interação entre antigos costumes misóginos, pulverizados em toda a Europa, e o discurso de cunho antifeminino, herdeiro da Antigüidade Clássica e da teologia moral cristã, vulgarizado em escala crescente desde o final da Idade Média. (...)., ${ }^{, 78}$

Na fantasia de Dom Jerônimo, Ana era diabólica e mentirosa, o que podia ser atribuído às mulheres de então, de acordo com a historiografia:

"Na crítica ostensiva às mulheres visava-se, de fato, à mulher do dia-a-dia, a esposa que não obedecia o marido, recusava a clausura doméstica, tecia mil artimanhas para enganar e driblar a vigilância patriarcal...Visava-se à mulher enquanto ser diabólico, 'beata fingida', ruína de todos os homens que por ela se perdessem. Ao infeliz marido de uma tal mulher só restava meter-lhe muita pancada, 'partí-la de meio-a-meio', 'quebrar-lhe um braço', 'acabar-lhe com a vida num momento'. (...).,

A construção do perfil das personagens femininas da família de Dom Braz nos pareceu herança do livro de Dinah Silveira de Queiroz. Porém, Ana foi uma personagem criada por Maria Adelaide Amaral. Incorporada ao núcleo, a personagem Dom Jerônimo tinha um discurso moralista e religioso, de acordo com sua visão restrita do mundo. Dom Jerônimo demonstrava um comportamento que hoje classificamos como doentio, mas era muito poderoso e aplicava suas próprias leis, sentindo-se autorizado por Deus. Via-se como um inquisidor, sem sê-lo.

\footnotetext{
${ }^{77}$ Ronaldo Vainfas. Trópico dos pecados: moral, sexualidade e Inquisição no Brasil Colonial. op. cit.

${ }^{78}$ Idem, p. 120.

${ }^{79}$ Idem, p. 121 .
} 


\title{
Imagem não disponível
}

\author{
para internet.
}

Dom Jerônimo caracterizado de inquisidor.

Na obra de Vainfas, também encontramos referências que podem ter colaborado para acrescentar elementos a personagens e tramas que já existiam na obra original. Como, por exemplo, Antônia, sobre a qual o padre Simão tenta explicar a Dom Jerônimo que mulheres como ela estavam vindo para a colônia, a pedido do padre Manoel da Nóbrega:

“(...). Meretrizes portuguesas a incendiar a já inflamada sensualidade tropical, e a ensejar, como na Metrópole, inúmeras 'defesas da fornicação simples'...Nosso caro Manoel da Nóbrega que por pouco escapou de uma grave doença na década de 1550, certamente morreria de desgosto se pudesse adivinhar no que resultaria seu apelo d'outrora, quando suplicara ao Rei o envio de meretrizes brancas para se casarem no Brasil., ${ }^{, 80}$

${ }^{80}$ Idem, p.63 e 64. 
Aspectos de relacionamento e casamento também foram encontrados em Vainfas, podendo complementar as tramas ficcionais, como o casamento arranjado de Cristina com o primo, feito através de cartas entre familiares era comum. ${ }^{81} \mathrm{E}$ apesar das fantasias românticas da personagem, ocorriam em sua maioria sem amor. ${ }^{82}$

Alcântara Machado e Ernani Silva Bruno estão no grupo de historiadores que foram apontados como fontes. A obra Vida e morte do bandeirante ${ }^{83}$, de Alcântara Machado, descreve aspectos da vida colonial paulista a partir de inventários do período. Por essa documentação, passou-se a conhecer melhor as condições econômicas da sociedade. Na ficção, houve comentários acerca da pobreza do paulista e dos bens que possuíam. Os inventários faziam descrições de objetos, o que pode ter sido valioso para o trabalho de cenógrafos.

Ernani Silva Bruno é conhecido por seu trabalho História e tradições da cidade de São Paulo, dividido em três volumes: Arraial de sertanistas (1554-1828), vol. I; Burgo de estudantes (1828-1872), vol. II; Metrópole do café (1872-1918) e São Paulo de agora (1918-1953), vol. III. Dos três volumes, o que foi utilizado como fonte foi o primeiro, que descreve aspectos de São Paulo no período colonial.

Possivelmente, foram utilizados alguns outros autores não indicados pelos produtores em entrevistas, mas que por informações na minisserie, pudemos identificar suas idéias, como as de John Monteiro ${ }^{84}$ e Alice Canabrava ${ }^{85}$.

A expressão "negros-da-terra", usada para para identificar os indígenas, é referente ao trabalho de John Monteiro.

$\mathrm{Na}$ passagem em que Guilherme comenta sobre a possibilidade de se fazer comércio de açúcar com Buenos Aires, temos referências ao trabalho de Alice Canabrava, que pesquisou o período da União Ibérica, retratado na minissérie. Esse comércio podia ser lícito, embora o porto vicentino não fosse o centro desse intercâmbio, mas o de Salvador. ${ }^{86}$

\footnotetext{
${ }^{81}$ Idem, p.123.

${ }^{82}$ Idem, p. 125 .

${ }^{83}$ Alcântara Machado. op. cit.

${ }^{84}$ John Manuel Monteiro. Negros da terra:índios e bandeirantes nas origens de São Paulo. São Paulo: Companhia das Letras, 1994.

${ }^{85}$ Alice Canabrava. op.cit.

${ }^{86}$ Idem, p. 123 .
} 
Assim, identificamos algumas fontes historiográficas e como as mesmas foram trabalhadas na ficção, servindo como argumento. Concluímos, contudo, que apesar da extensa pesquisas dos produtores da minissérie, não há a necessidade de ser fiel aos aspectos históricos. Consideramos que os produtores procuram especialmente fidelidade quanto a fatos e datas, porém nomes, relacionamentos e alguns aspectos do cotidiano material foram alterados.

Sabemos que não esgotamos todas as possibilidades de temas e fontes para $A$ Muralha, mas pretendemos com este trabalho, levantar possibilidades de discussão sobre esta obra e suas diversas versões. 


\section{CAPÍTULO III - UM SÓ CORAÇÃO}

Este capítulo está centrado na apresentação da minissérie histórica Um Só Coração, veiculada no ano de 2004, como parte das comemorações dos 450 anos de fundação de São Paulo, data considerada relevante pelo Departamento Comercial da Rede Globo.

Apresentamos o histórico da produção, com as atividades que a antecederam e um resumo da minissérie. Procuramos demonstrar o forte esquema de propaganda e divulgação montado para o lançamento da minissérie e como ela se tornou um sucesso comercial, estimulando publicações, visitas a instituições culturais e exposições.

\section{UM PRESENTE PARA SÃO PAULO}

A Rede Globo pretendia aproveitar os 450 anos da cidade de São Paulo com uma minissérie para homenagear a cidade e pediu para Maria Adelaide Amaral pensar sobre o assunto. A autora acabara de escrever uma peça de teatro sobre Tarsila do Amaral, que havia estreado em São Paulo, e, portanto, havia pesquisado sobre a pintora, seus amigos e seu tempo. Propôs, então, aos responsáveis na emissora, uma minissérie que contasse a história de São Paulo sob o viés da cultura, começando com a Semana de Arte Moderna, em 1922, e terminando com as festividades do IV Centenário de São Paulo, que incluíam a II Bienal, em 1954. Com a idéia pronta, escolheu um parceiro, Alcides Nogueira:

“... 'pretendo trabalhar com Alcides Nogueira. Quem mais senão o Tide para se juntar a mim nesse projeto?' Era de família quatrocentona, tinha escrito uma peça sobre a Revolução de 32, Paris-Belfort, outra sobre a Semana de Arte-Moderna, Tietê, Tietê, e conhecia esse universo como ninguém. Além disso, era meu amigo, culto, leal, bom caráter. Eu tinha certeza que ele seria um excelente companheiro, como havia sido Walter Negrão. Depois, acreditava que duas cabeças pensam melhor que uma."

\footnotetext{
${ }^{1}$ Tuna Dwek. Maria Adelaide Amaral: a emoção libertária. São Paulo: Imprensa Oficial do Estado de São Paulo: Cultura - Fundação Padre Anchieta, 2005, p.253.
} 


\section{A peça teatral}

A peça Tarsila fora escrita a pedido da atriz Ester Góes e do diretor de teatro Sérgio Ferrara. O processo de elaboração da peça se iniciou em novembro de 2001 e foi até março de 2002, exigindo uma grande pesquisa, que foi realizada por Luciana Chen, formada em Artes Plásticas e já então autora de trabalhos importantes no Museu de Arte Brasileira da FAAP. Além de Tarsila do Amaral, outras personagens importantes do período, como Anita Malfatti, Oswald de Andrade e Mário de Andrade deveriam ser incluídas.

No percurso de pesquisa, Maria Adelaide pode conhecer, conversar e ter a colaboração da sobrinha-neta da pintora, também chamada Tarsila do Amaral e de seus familiares. Através deles, conheceu o artista Tuneu, aluno e confidente de Tarsila, Anna Maria Martins e Ana Luísa Martins. Anna Maria é viúva de Luís Martins, que foi companheiro de Tarsila por muitos anos, e ambos apareceram como personagens da minissérie.

Entre os contatos e uma longa pesquisa contatou também parentes de outras personagens, além de professores e especialistas. Entre as pessoas que foram contatadas e colaboraram estão arroladas: Antonio Candido, Gilda de Mello e Souza, Jorge Miguel Marinho, Telê Ancona Lopez, Beth Malfatti, Guilherme Amaral, Aracy Amaral, Radá Abramo, Rudá de Andrade, Timó de Andrade e Lélia Coelho Frota.

Além das entrevistas acima citadas, leu toda a obra dos escritores Oswald de Andrade e Mário de Andrade, a revista Antropofagia e uma vasta bibliografia, que levantou em suas pesquisas. ${ }^{2}$

Pode contar com colaboração de muitas pessoas, tais como Marlyse Meyer, que cedeu a Revista de Antropofagia. Utilizou depoimentos gravados em institutos culturais, como: Mário: um homem desinfeliz, do Instituto Itaú Cultural; Depoimento de Antonio Candido sobre Oswald de Andrade, gravado no Museu de Imagem e Som/Secretaria da Cultura de São Paulo, em 1999; Cem Oswald Anos, depoimento gravado no almoço

\footnotetext{
${ }^{2}$ Tarsila, sua obra e seu tempo - Aracy Amaral; Tarsila do Amaral- Nádia BatteIla Gotlib; Correspondência de Mário de Andrade e Tarsila do Amaral - org. Aracy Amaral; Cartas a Anita Malfatti - Mário de Andrade; O salão e a selva - Maria Eugênia Boaventura; Oswald de Andrade - Maria Augusta Fonseca; Anita Malfatti no tempo e no espaço - Marta Rossetti; Um bom sujeito - Luís Martins; Pagu - vida e obra - Augusto de Campos; Mário de Andrade: exílio no Rio de Janeiro - Moacir Werneck de Castro; Te dou a lua amanhã biofantasia de Mário de Andrade - Jorge Miguel Marinho; A lição do amigo - Cartas de Mário de Andrade a Carlos Drummond de Andrade; Mário de Andrade por ele mesmo - Paulo Duarte
} 
promovido no MIS/SP por ocasião dos 100 anos do nascimento de Oswald. ${ }^{3}$

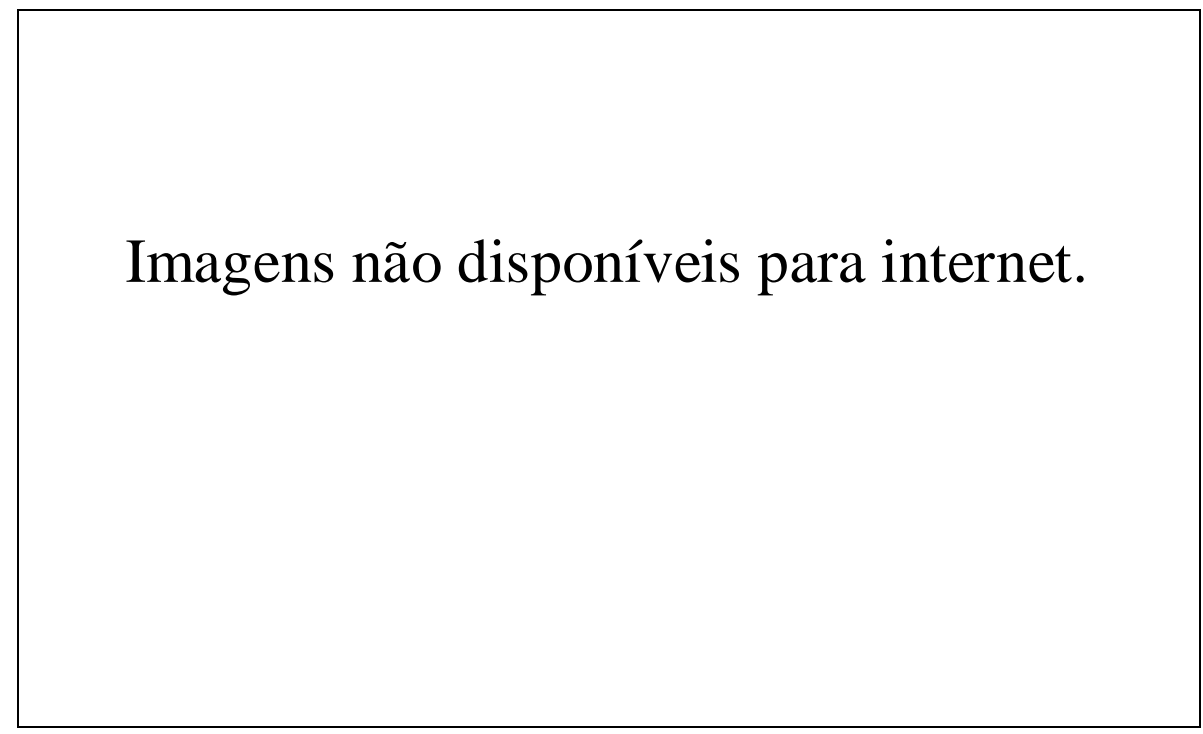

Capa do livro e programa da peça Tarsila, de Maria Adelaide Amaral.

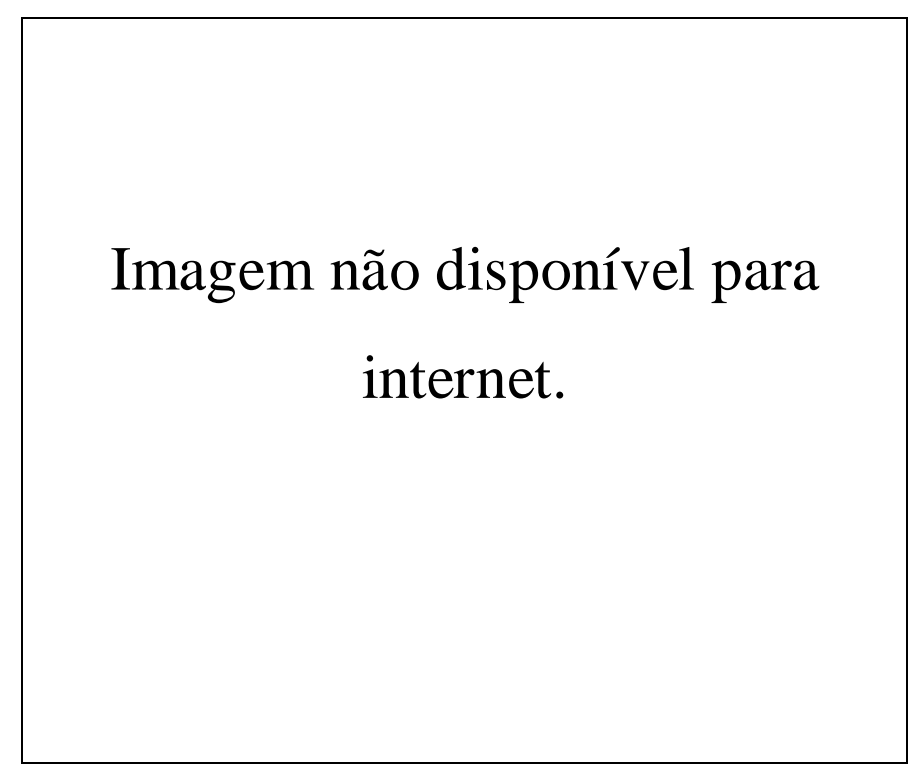

Eliane Giardini, caracterizada como Tarsila.

\footnotetext{
${ }^{3}$ As informações sobre a peça Tarsila foram retiradas de: Maria Adelaide Amaral. A aventura de escrever Tarsila. In: - Tarsila. São Paulo: Globo, 2004, p.5-8.
} 


\section{A minissérie e seus produtores}

A partir da escrita da peça teatral, Maria Adelaide possuía conhecimento e muito material para elaborar a minissérie Um Só Coração. Além disso, contava com a experiência e conhecimento de Alcides Nogueira, que havia escrito as peças Tietê- Tietê, encenada em 1979, no Estúdio São Pedro ${ }^{4}$, e a inédita Paris- Belfort, de $1989 .{ }^{5}$

Apesar de o objetivo central proposto ser a cultura, explorou vários outros temas importantes do período. A minissérie retratou, mesmo em forma ligeira, praticamente todos os acontecimentos importantes entre os anos 20 e 50 do século XX. As transformações na cidade de São Paulo nos aspectos políticos, sociais e econômicos também apareceram: decadência do café, início da industrialização, imigração, migração e revoltas políticas foram utilizadas como argumento para que personagens reais e fictícias tivessem suas histórias desenvolvidas.

Segundo a autora em sua biografia, não houve interferência quanto ao conteúdo da obra, ou escolha de co-autor, mesmo sendo um pedido da emissora a elaboração de uma minissérie sobre São Paulo. ${ }^{6}$

Explorando a passagem acima citada, na ressaltada atuação do Departamento Comercial, que sugeria atenção especial para São Paulo pelo seu aniversário de fundação, podemos pensar que havia naquele momento um interesse da emissora no mercado paulista, que motivou o aproveitamento da data. As efemérides são grandes atrativos para a programação televisiva, pois atraem muitos anunciantes interessados em atingir o público consumidor.

\section{PROPAGANDA, INTERAÇÃO E REPERCUSSÃO}

O interesse comercial apareceu muito claramente, em nosso entender, quando localizamos os eventos que antecederam o lançamento da minissérie e que de forma clara estavam relacionados a ela. Destacaram-se pela qualidade e pelos circuitos culturais e sociais envolvidos. Podemos dizer que a promoção de Um Só Coração movimentou o

\footnotetext{
${ }^{4}$ Tuna Dwek. Alcides Nogueira: Alma de cetim. São Paulo: Imprensa Oficial, 2004, p.174.

${ }^{5}$ Idem, p.14

${ }^{6}$ Tuna Dwek. Maria Adelaide Amaral, op. cit., p.251 a 253.
} 
circuito cultural da cidade de São Paulo e também o emocional, pois buscou atingir a memória social dos grupos imigrantes do início do século XX.

O primeiro evento foi o do Museu de Arte Moderna/MAM de São Paulo, que fez uma exposição no Ibirapuera entre 13 de dezembro de 2003 e 18 de janeiro de 2004, na qual foram expostas obras, pertencentes ao acervo do museu, de artistas modernistas que seriam retratados na minissérie. Além disso, apresentou também objetos sobre a história e preparação da minissérie como: vídeo de cenas, figurinos, jóias e estudos para a montagem de personagens ${ }^{7}$. A exposição foi bastante significativa, já que Ciccillo Matarazzo e Yolanda Penteado, protagonistas da minissérie, foram os fundadores da instituição.

O MAM/SP foi fundado em $1948^{8}$, mas sua primeira exposição foi em 1949:

"Em 1949, inaugura-se a primeira exposição do Museu de Arte Moderna, denominada Do Figurativismo ao Abstracionismo (sic), iniciando aquele que, como veremos, será o maior debate da arte brasileira desde a Semana de 22: a oposição entre a estética figurativa e a abstrata e suas consequiências para a emancipação da arte brasileira. O crítico brasileiro Sérgio Milliet, na época também membro do Clube dos Artistas e Amigos da Arte, foi um dos organizadores da primeira exposição do Museu, ao lado do belga Léon Degand, no cargo de diretor artístico. $(\ldots){ }^{9}$

É do conhecimento geral no circuito cultural que o acervo original do MAM/SP da época foi doado por Ciccillo Matarazzo à Universidade de São Paulo, coleção que deu origem ao Museu de Arte Contemporânea MAC/USP. A decisão gerou grande polêmica. O MAM/SP teve que reconstruir seu acervo, pois Ciccillo Matarazzo, envolvido com o crescimento da Bienal, achou melhor separar o museu e a mostra, que estavam vinculados.

$\mathrm{O}$ MAM/SP se refez ${ }^{10}$ e hoje possui um novo acervo e promove atividades culturais como exposições de arte, serviço educativo, exibição de filmes, além de possuir uma biblioteca aberta à visitação. É um dos mais importantes museus de arte da cidade.

\footnotetext{
${ }^{7}$ Daniel Castro. Outro Canal: Vernissage 1 e Vernissage 2. Folha de S. Paulo, 27/11/2003, caderno Ilustrada p. E 10.

${ }^{8}$ José Carlos Durand. Arte, privilégio e distinção: artes plásticas, arquitetura e classe dirigente no Brasil (1855-1985). São Paulo: Perspectiva; Editora da Universidade de São Paulo, 1989, p. 120.

9 Francisco Alambert \& Polyana Lopes Canhete. As bienais de São Paulo: da era do museu à era dos curadores (1951-2001). São Paulo: Boitempo, 2004, p.32.

${ }^{10}$ Idem, p.93-102.
} 
Uma outra atividade cultural concretizada em função da minissérie foi o Circuito cultural Um Só Coração, no Memorial do Imigrante/Secretaria da Cultura de São Paulo. O evento promovia a minissérie, com um festival gastronômico, exposição e danças típicas, e estava direcionado ao público que se considera descendente dos imigrantes que vieram para a cidade no início do século XX.

O Memorial do Imigrante está localizado em parte do prédio da antiga Hospedaria de Imigrantes do Brás, que foi inaugurada em 1887, com a finalidade de receber os imigrantes de diversas nacionalidades que vinham para a então província de São Paulo. Foi criado em 1998, e, além de conter um museu com material sobre imigração, possui serviço educativo, biblioteca, arquivo, sendo possível consultar os livros de registros de desembarque dos navios que atracaram no porto de Santos. ${ }^{11}$

O acervo documental do Memorial é muito procurado, pois requisitam seus serviços de pesquisa histórica tanto às pessoas que desejam localizar seus antepassados e reconstituir a trajetória da família, como as que em nossos dias buscam a documentação com intuito de conseguir dupla nacionalidade.

O evento contou com a promoção da Rede Globo e utilizou também o logotipo da minissérie, demonstração de quanto a emissora estava interessada em vincular a minissérie a uma instituição histórico-cultural da cidade, que atende a estudantes de ensino fundamental e médio e interessados no passado em geral.

Foi realizada posteriormente uma exposição com outro tema, $O$ vestir em São Paulo pela lente de Um Só Coração, no Centro de Design e Moda Anhembi Morumbi, da Faculdade Anhembi Morumbi, apresentada entre 29 de abril e 28 de maio de 2004, com entrada franca. A mostra reuniu 70 figurinos originais, que foram de responsabilidade de Emilia Duncan. Foram os professores da universidade que organizaram a exposição e um seminário: A história da moda em São Paulo - reflexões sobre fatos e personagens. Este seminário pode ser considerado a entrada da minissérie no circuito acadêmico.

\footnotetext{
${ }^{11}$ As informações sobre o Memorial do Imigrante foram retiradas de: Imigração italiana no Estado de São Paulo. São Paulo: Secretaria de Estado da Cultura, Memorial do Imigrante/ Museu da Imigração, 1999, p.17. (Série Resumos, n⿳亠口冋 1) e http://www.memorialdoimigrante.sp.gov.br/institucional/index.asp .
} 
A minissérie também já foi objeto de estudo em uma tese de doutorado da ECA/USP, São Paulo: território intercultural de Um Só Coração, de Oriana Monarca White, que trabalhou com questões de mídia, interculturalidade e identidade, através dos imigrantes retratados na obra. A autora pôde acompanhar a minissérie desde um pouco antes de sua estréia e estudar a repercussão na mídia. ${ }^{12}$

A própria produtora e emissora, a Globo, também elaborou um site, seguindo o padrão de outras produções, atualizado diariamente, enquanto exibia a minissérie. ${ }^{13} \mathrm{Na}$ internet, a produção também conquistou fãs no Orkut, em uma comunidade com mais de 500 participantes. ${ }^{14}$ Da mesma forma que a própria minissérie, autores, atores, diretores e outras produções dos mesmos também possuem comunidades neste site de relacionamentos.

Um Só Coração atendeu a um objetivo da autora com suas minisséries: despertar o interesse sobre o tema abordado.

Para a emissora, a minissérie foi rentável, pois além da propaganda obtida, da audiência, ela permitiu o lançamento de diversos produtos, tais como um CD com a trilha sonora, um livro sobre os bastidores da minissérie e a edição em DVD.

O CD com temas musicais é um produto padrão, isto é, feito para todas as telenovelas, com as músicas que identificam personagens e situações. O CD de Um Só Coração, lançado pela gravadora Som Livre, pertencente à empresa Globo, traz doze músicas, cantadas pelos seguintes artistas:

1. Too young - Roger Henri

2. Soledad-Roger Henri

3. Os rios que correm pro mar - Teresa Cristina

4. Família alemã - Roger Henri

${ }^{12}$ Oriana Monarca White. São Paulo: território intercultural de Um Só Coração. Tese de Doutorado. São Paulo: CCA-ECA/USP, 2005.

${ }^{13} \mathrm{http} / / /$ redeglobo.globo.com/Umsocoracao/0,18529,3131,00.html

${ }^{14}$ O Orkut é um site de comunidade on-line, que conecta as pessoas através de uma rede de amigos. Nele é possível criar uma página própria, na qual consta seus amigos, informações pessoais e recados. Pode-se também criar e participar de comunidades diversas por afinidade de gosto, ou opinião. Virou febre entre os brasileiros nos últimos anos. Espaço que revela muito do comportamento das pessoas nos dias atuais. Ver endereço da comunidade: http://www.orkut.com/Community.aspx?cmm=1330644 
5. Um Só Coração - (adaptação da Sinfonia no 5 op.64, de Tchaikovsky)

6. Tum Balalaica - Gilbert

7. Rapaziada do Braz - Jair Rodrigues

8. Pot-pourri João de Barro Cabocla Tereza - Trovadores Urbanos

9. In the blue of the evening - Tommy Dorsey \& Frank Sinatra

10. Coração sozinho (adaptação de Apenas um coração solitário) - Roger Henri

11. Viola quebrada - Trovadores urbanos

12. Ária Paulistana (Adaptação da Sinfonia $n^{\circ} 5$ op.64, de Tchaikovsky)

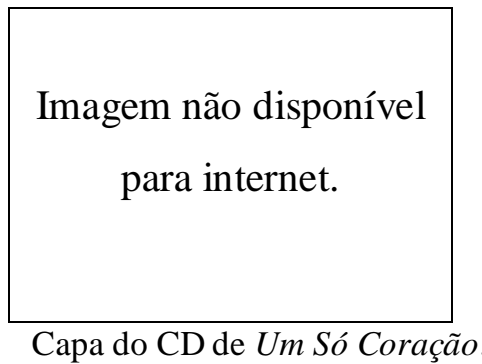

O livro sobre os bastidores é um produto elaborado normalmente para minisséries. Aquarela do Brasil e A Casa das Sete Mulheres também tiveram edições sobre os bastidores. Entre as novelas, foram feitas para O Clone e Esperança (2002/2003). Dessas produções, três foram dirigidas por Jayme Monjardim (também diretor de núcleo), que costuma fotografar os bastidores durante o processo de produção.

São Paulo através da minissérie Um Só Coração ${ }^{15}$ traz informações sobre São Paulo de Piratininga, com os antecedentes da grande metrópole. E há explicações sobre o enredo, personagens, produção e figurino e, finalmente, informações históricas sobre o período da minissérie: datas, fatos, personagens e costumes. O livro possui várias imagens da minissérie e também imagens de época, como retratos das personagens de existência real e paisagens da cidade, e foi lançado pela editora Globo.

\footnotetext{
${ }^{15}$ São Paulo através da minissérie Um Só Coração. São Paulo: Editora Globo, 2004.
} 


\section{Imagem não disponível}

\section{para internet.}

Capa do livro sobre os bastidores da minissérie, lançado pela editora Globo.

Mas não só a empresa Globo de comunicação aproveitou o momento para lançamento de produtos relacionados com a minissérie. Outras empresas, tais como editoras, lançaram livros relacionados com personagens da produção. Eram trabalhos que já existiam há anos, desconhecidos até então, e que foram aproveitados pelas editoras comercialmente, em um momento em que o interesse por essas personagens e pelo período histórico cresceu. Apresentamos alguns exemplos.

O livro Dia seguinte e outros dias ${ }^{16}$, de Oswald de Andrade Filho, mais conhecido como Nonê, foi um desses resgates de memória. Timo de Andrade, filho de Nonê, deixou que Maria Adelaide o utilizasse, antes de ser publicado, para a peça Tarsila. A obra é uma espécie de biografia poética de Oswald, organizada por Timo e Maria Eugênia Boaventura, e até então não tinha encontrado editora. Maria Adelaide colaborou para que fosse publicado. ${ }^{17}$

Aí vai meu coração: cartas de Tarsila do Amaral e Anna Maria Martins para Luís Martins foi lançado em dezembro de $2003^{18}$. Apresenta as cartas que Tarsila escreveu para Luís Martins, que eram até então inéditas e desconhecidas, até mesmo por especialistas na

${ }^{16}$ Oswald de Andrade Filho. Dia seguinte e outros dias. São Paulo: Códex, 2004.

${ }^{17}$ Conforme informações em Maria Adelaide Amaral. A aventura de escrever Tarsila., op. cit., p.6. E de Cassiano Eleck Machado. "Lições" de Nonê surgem em estréia póstuma. Folha de S. Paulo, 21/03/2004, caderno Ilustrada, p. E3.

${ }^{18}$ Conforme informação de nota publicada por Cassiano Eleck Machado na seção Livros/Lançamentos, no caderno Ilustrada, p. E4, Folha de S. Paulo, em 6 de dezembro de 2003; a obra é de Ana Luísa Martins, Aí 
sua obra. Quando terminou o casamento de Tarsila e Luís, ele se casou com Anna Maria. O livro inclui também cartas de Anna Maria para Luís Martins, trechos da autobiografia do crítico e crônicas publicadas por ele, que tratam das dificuldades da separação e do novo casamento. As provas do livro já haviam sido cedidas para Maria Adelaide na pesquisa da peça Tarsila, por Ana Luísa Martins, autora do livro e filha de Anna Maria e Luís. Lançado um pouco antes da minissérie, foi mais um dos livros sobre personagens dela e ajudou na construção do enredo.

Um outro livro, Yolanda ${ }^{19}$, de Antonio Bivar, já estava planejado, porém também foi lançado em 2004. A idéia de fazer uma biografia de Yolanda surgiu quando Bivar lembrou de uma passagem do livro de memórias dela, Tudo em cor-de-rosa, ${ }^{20}$ para utilizar em outro trabalho. Relendo o livro, deu-se conta que Yolanda fazia cem anos em 2003. Inicialmente, pensou em escrever uma biografia de bolso, sem grandes pesquisas. Ao saber da minissérie ficou preocupado, pois achariam que ele só estava fazendo o livro por causa disso. Entrou em contato com Maria Adelaide, que era sua amiga, e ela sugeriu que não fizesse um livrinho, mas um best-seller:

\begin{abstract}
"Best-seller não sei, mas decidi então escrever um blockbuster de umas trezentas páginas. É claro que aí o compromisso teria que ser maior, eu teria que ir além da despretensão que fora a idéia inicial, isto é, teria que pesquisar, conversar com parentes da biografada e pessoas que a conheceram bem, ir nas bibliotecas, nos arquivos, navegar na Internet, seria trabalho para mais de ano e isto se contasse com alguma bolsa ou patrocínio. Mas como nunca fui de ir atrás de bolsa e a coisa pedia urgência - o ideal, segundo Maria Adelaide, era que o livro saísse simultaneamente ao lançamento da minissérie, mesmo que não tivesse nada a ver com a mesma - o jeito era não pensar e fazer. Era now ou never.",21
\end{abstract}

Na procura por editoras, a notícia chegou a Pedro Paulo de Sena Madureira, diretor da editora A Girafa, que estava em fase de estruturação ${ }^{22}$. O interesse de Pedro Paulo, além de comercial, possivelmente teve também outra razão, pois foi vice-presidente de duas gestões da Fundação Bienal de São Paulo, e atuou na organização das exposições, tanto na

vai meu coração: cartas de Tarsila do Amaral e Anna Maria Martins para Luís Martins. São Paulo: Planeta, 2003.

${ }^{19}$ Antonio Bivar. Yolanda. São Paulo: A Girafa Editora, 2004.

${ }^{20}$ Yolanda Penteado. Tudo em cor-de-rosa. Rio de Janeiro: Nova Fronteira, 1976.

${ }^{21}$ Antonio Bivar. op. cit., p.13.

${ }^{22}$ Idem, p.14. 
XXII Bienal Internacional de São Paulo (1994) como na XXIII Bienal Internacional de São Paulo (1996).

O livro foi lançado em janeiro de 2004. A relação de Bivar com Yolanda era afetiva, desde que leu Tudo em cor-de-rosa, trinta anos antes de iniciar seu projeto. ${ }^{23}$

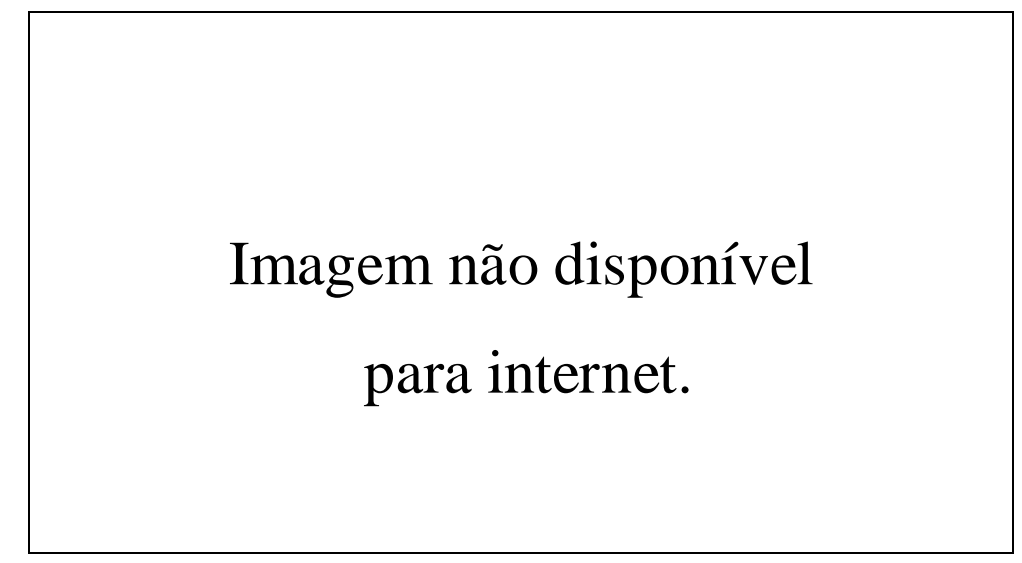

Yolanda, de Antonio Bivar. Um dos livros lançados na época da minissérie.

A peça Tarsila também foi beneficiada com a minissérie. Foi lançada em livro pela editora Globo e teve uma remontagem, graças ao entusiasmo de Eliane Giardini com sua personagem. Tarsila, Oswald e Mário foram respectivamente interpretados pelos atores Eliane Giardini, José Rubens Chachá e Pascoal da Conceição, todos do elenco da minissérie, com os mesmos papéis. A exceção ficou para a atriz Agnes Zuliani, que interpretou na peça Anita Malfatti. Na minissérie, a pintora foi interpretada por Betty Gofman. A peça estreou em 2 de julho de 2004, no teatro São Pedro de Porto Alegre. ${ }^{24}$

Outros tipos de produtos também foram lançados aproveitando o sucesso e o interesse suscitado pela minissérie. Entre esses produtos foram lançadas revistas, de caráter mais popular, vendidas em bancas de jornal. Uma delas, por exemplo, publicada pela editora Escala tem o título Revoluções brasileiras: Revolução de $1932^{25}$. De acordo com foto na capa desta edição, a editora produziu algo semelhante sobre a Guerra dos Farrapos,

\footnotetext{
${ }^{23}$ João Luiz Sampaio. Versões de uma mulher chamada Yolanda. O Estado de S. Paulo, 18/01/2004, Caderno 2 , p. D6.

${ }^{24}$ Tuna Dwek. Maria Adelaide Amaral: a emoção libertária, op.cit, p..269.
} 
em função de A Casa das Sete Mulheres. Também produziu uma edição especial da revista TV Brasil, com a capa: "Um Só Coração, uma história de amor e coragem.” Na edição sobre 32 aparece a propaganda da TV Brasil. São produtos de apelo popular e preço baixo, ${ }^{26}$ nos quais são utilizadas fotos da minissérie e seus artistas para atrair compradores. A revista é bastante ilustrada, inclusive com imagens da época, como, por exemplo, uma foto de João Pessoa morto e a aclamação de Pedro de Toledo na Praça da Sé. ${ }^{27}$

Esta publicação possui grande semelhança visual e de conteúdo com o livro sobre a minissérie, editado pela Globo. Os temas são muito parecidos, com caráter ufanista, como indica o editorial da revista:

"Quando se pensa a Revolução de 32, logo vem à mente a bravura do povo paulista que pegou em armas contra todo o país para defender o ideal constitucionalista. $\mathrm{O}$ que pouco se fala, porém, é que São Paulo foi traído pelos seus aliados e se viu isolado, mal armado e com poucos recursos financeiros para enfrentar a luta. Mesmo assim, sustentou sua causa com uma dignidade rara, com verdadeira 'fibra de herói'.

Acompanhe-nos através deste túnel do tempo que irá conduzir você a uma galeria de personagens que ajudaram a moldar a face do Brasil do século XX. Conheça os bastidores da política, os motivos que conduziram a essa verdadeira guerra. Saiba a respeito das armas e artimanhas que os paulistas inventaram para minimizar a falta de recursos, do papel da mulher durante a revolução, da mobilização nas ruas, dos movimentos estudantis. Venha conosco nesta viagem ao passado e veja a história através dos olhos de quem a fez. É só assim que podemos entender melhor o nosso presente." 28

Não é muito diferente a proposta no texto de apresentação do livro da Globo:

"Da isolada Vila de Piratininga à próspera capital do café. De uma cidade urbanizada à francesa a centro de difusão da cultura brasileira. De capital das artes à maior metrópole brasileira.

São Paulo através da minissérie "Um Só Coração" apresenta um panorama diferente da cidade de 450 anos, oferecendo ao leitor uma nova maneira de aprender história.

Baseado na trama de Um Só Coração, a minissérie de Maria Adelaide Amaral e Alcides Nogueira levada à tevê pelos diretores Carlos Manga e Carlos Araújo, este livro reúne fotos reais e imagens produzidas que enfocam os principais fatos e protagonistas da São Paulo antiga.

\footnotetext{
${ }^{25}$ Revoluções brasileiras: Revolução de 1932. São Paulo: Escala, 2004.

26 O preço da publicação é baixo: o exemplar sobre a Revolução de 32 tem na capa o valor de $\mathrm{R} \$ 4,90$, valor que é bem mais acessível do que o preço de um livro.

${ }^{27}$ Revoluções brasileiras: Revolução de 1932. São Paulo: Escala, 2004, p.8 e 14.

${ }^{28}$ Idem, p.3.
} 
Mário e Oswald de Andrade, Anita Malfatti e Tarsila do Amaral, Paulo Prado e Assis Chateaubriand, Yolanda Penteado e Ciccillo Matarazzo aqui convivem na cidade das décadas de 1920 a 1950, unindo-se a outros personagens da história, num verdadeiro passeio pelo tempo e pela memória paulistana.

Faça essa viagem." 29

O texto é assinado pelos editores e, como a revista, reflete uma preocupação em atrair o leitor para o aprendizado da história. Porém, não com uma preocupação pedagógica, mas de entretenimento, o que é indicado por expressões como: "unindo-se a personagens num passeio pelo tempo", "viagem ao passado" ou "nova maneira de aprender história". O texto da revista ressalta "a bravura do povo paulistano"; o texto do livro enfatiza o crescimento da cidade. Ambos colaboram para uma construção de imagem da cidade e dos seus habitantes, reforçando aspectos retratados na minissérie, como a transição da cafeicultura para a industrialização e principalmente a luta pela Constituição em 1932. Em ambos há textos informativos, destinados ao público leigo, não se diferenciando muito quanto ao conteúdo. Quanto a qualidade visual, material e em pesquisa bibliográfica o livro é superior.

Revista popular, contando a Revolução de 1932, com informações da minissérie.

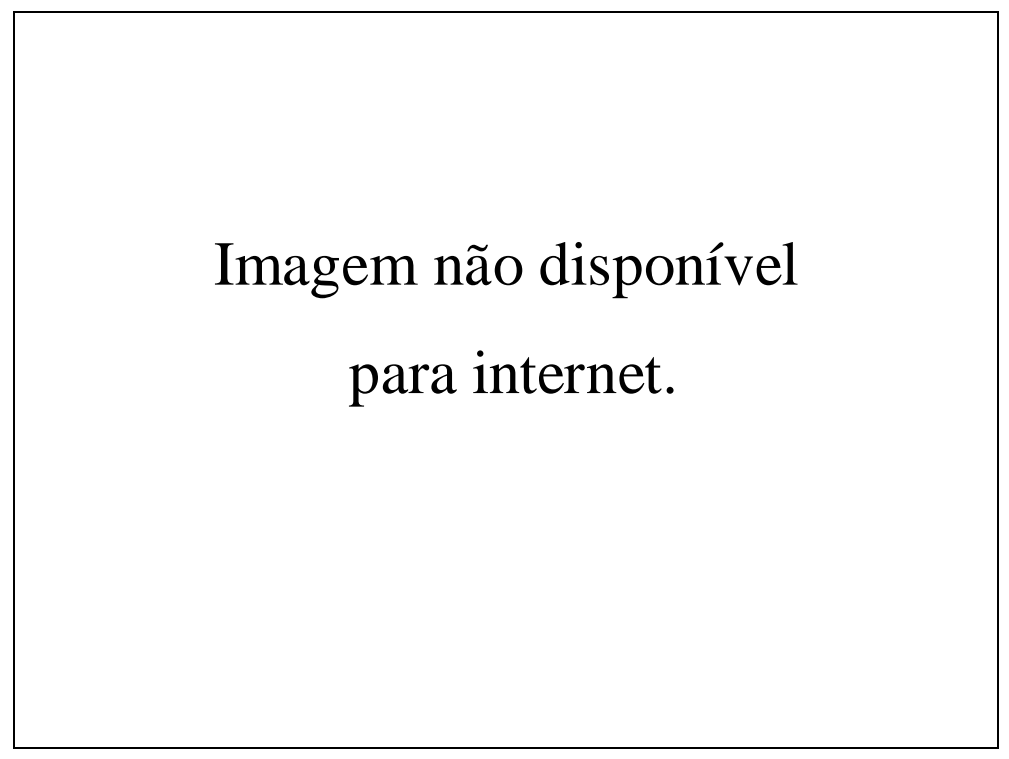

\footnotetext{
${ }^{29}$ São Paulo através da minissérie Um Só Coração. São Paulo: Editora Globo, 2004, p.7.
} 
O sucesso da minissérie rendeu ainda uma edição em DVD. ${ }^{30}$ Em 2004 a Globo lançou as minisséries Os Maias e Agosto também para venda. Várias minisséries foram lançadas um pouco antes dessa época, além de outras produções da emissora ${ }^{31}$. A Globo já vinha em um processo de lançar suas produções no mercado e isto só foi se consolidando desde então.

O interesse e sucesso de Um Só Coração foi tão grande, que até houve político pretendendo se aproveitar do fato. Em fevereiro de 2004, em pleno período de exibição da minissérie, Paulo Maluf, que usa um coração como símbolo, teve problemas com sua propaganda, como relata uma notícia da época:

“' 'Populares' que mais parecem coadjuvantes de 'pegadinha' surgem dizendo, ininterruptamente:

São Paulo tem a cara do Maluf...Foi o melhor prefeito que São Paulo já teve...A gente trabalha na rua e vê as obras que ele faz...O que mais fez por São Paulo foi Paulo Maluf.

E tome imagens de Cingapura, do túnel Ayrton Senna, do próprio ex-prefeito. E mais 'populares':

Maluf tá no coração...É Maluf no coração...Maluf tá no coração.

Por fim o slogan:

Maluf e São Paulo, um só coração.

Os novelistas Maria Adelaide Amaral e Alcides Nogueira, da mininovela Um Só Coração, soltaram um e-mail afirmando que não aceitam o uso do título 'de forma melíflua pelo senhor Paulo Maluf. (...)., ${ }^{, 32}$

A Globo notificou o Partido Progressista, que teve que suspender o uso da propaganda.

Algo semelhante aconteceu com outra produção, mas o autor não tomou providências, apenas não concordou com a postura do candidato. Trata-se do senador eleito Eduardo Suplicy (PT/SP) e do autor Manoel Carlos, autor da atual "novela das oito", Páginas da Vida. A campanha de Suplicy utilizou o efeito gráfico dos depoimentos feitos no final da novela. ${ }^{33}$

\footnotetext{
${ }^{30}$ Maria Adelaide Amaral \& Alcides Nogueira. Um Só Coração (DVD). Globo Vídeo, 2004.

${ }^{31}$ Consulta feita ao site: http://somlivre.com.br/

${ }^{32}$ Nelson de Sá. Sem coração. Folha de S. Paulo, 11/02/2004, caderno Ilustrada, p. E8.

${ }^{33}$ Laura Mattos. "Ser vilão está na moda". Folha de S. Paulo, 24/09/2006, caderno Ilustrada, p.E1 e E3, caderno Ilustrada. Na entrevista, Manoel Carlos fala sobre política e sobre a mudança da personagem Tereza, interpretada por Renata Sorrah, que inicialmente seria uma juíza, personagem inspirada em Denise Frossard,
} 
O conteúdo de uma novela pode influenciar muito a opinião pública e o sucesso dela pode ser usado também de maneira a influenciar o eleitorado, mesmo quando seus produtores não são coniventes com seu uso político. O sucesso de uma novela ou minissérie pode fazer que certos elementos da produção sejam apropriados em situações de eleições e promoção de candidatos.

\section{O reconhecimento}

O resultado satisfatório e o sucesso da minissérie deram a Maria Adelaide um reconhecimento importante. Ela recebeu o título de "Cidadã Paulistana", oferecido pela Câmara Municipal de São Paulo e entregue na Fundação Bienal de São Paulo, em 07 de abril de 2004. Transcrevemos a seguir o discurso:

\section{CÂMARA MUNICIPAL DE SÃO PAULO}

Pronunciamento do Vereador Alcides Amazonas por ocasião da entrega do Titulo de Cidadã Paulistana a escritora Maria Adelaide Amaral.

Houve um tempo, um tempo longo, mais de três séculos, em que quem nascia no Brasil era português.

A ruptura de 1822 foi, ao mesmo tempo, um ato de independência do colonialismo, e, também, a clássica separação do filho que ao crescer deixa a tutela dos pais. Nunca, no entanto, nem nos episódios mais sangrentos da grande guerra da Independência, brasileiros e portugueses deixaram de repartir sua evolução comum. Fratemidade - esta sempre foi a palavra de ordem entre nossos povos.

Sempre foi tão forte que o próprio Patriarca da Independência, José Bonifácio de Andrada e Silva, acalentou o sonho de proclamar não um Reinado do Brasil, mas o Império Luso-Brasileiro.

Seguimos nossa trilha de autonomia sem nunca fechar o porto às caravelas que partiam da praia do Rastelo em direção ao Novo Mundo. O Brasil, terra da aventura, do enriquecimento, paraíso dos trópicos, seara da liberdade, onde os europeus podiam livrar-se do grilhão feudal, sempre foi o porto seguro dos que queriam saber o que havia do outro lado do mundo.

Estamos aqui para homenagear uma dessas navegantes que o poeta Fernando Pessoa tangeu com o verso "navegar é preciso". Nascida na cidade do Porto, a mais nova cidadã de São Paulo embarcou na caravela para aqui fazer-se paulistana de fato, de alma e coração, condições superiores à cidadania que a solenidade de hoje apenas formaliza oficialmente.

candidata do PPS ao governo do Rio de Janeiro e o autor precisou mudar a personagem para não parecer propaganda política. 
A paulistana Maria Adelaide Amaral é uma 'artista do povo', e esta condição não tem fronteiras.

Inevitável lembrar de outra portuguesa que adotou o Brasil com a sua arte de encantar o mundo: Carmen Miranda.

Nossa homenageada é mais conhecida por seu trabalho na televisão. No entanto, é grande e significativa sua contribuição ao teatro e à literatura, e foram estas artes que a consagraram na brasileiríssima forma de narrativa que é a novela da TV.

Dramaturga premiada, escreveu peças como Chiquinha Gonzaga, De Braços Abertos e Querida Mamãe, todas vencedoras do Moliére, além de Bodas de Papel, A Resistência, $O$ Abre Alas, Intensa Magia, que foi levada ao cinema no filme Querido Estranho, de Ricardo Pinto.

Entre seus romances destacam-se Luísa: Quase uma História de Amor, e O Bruxo. Traduziu peças de autores consagrados, e fez uma adaptação para o teatro do romance O Evangelho Segundo Jesus Cristo, do compatriota e Prêmio Nobel da Língua Portuguesa José Saramago.

Desde sua estréia nas novelas da TV, como co-autora de Meu Bem, Meu Mal, em parceria com Cassiano Gabus Mendes, na Rede Globo, Maria Adelaide Amaral constitui prova de que há vida inteligente na televisão. Ela faz parte de um seleto time de novelistas que podemos chamar de artistas do folhetim eletrônico. Esta forma de narrativa, mesmo com as limitações naturais, impostas pelo rei ibope, sobressai na cultura brasileira com momentos de criação comparáveis aos dos nossos melhores romancistas.

Suas novelas e seus seriados resgatam a epopéia do povo brasileiro em várias oportunidades.

Chiquinha Gonzaga não foi, por exemplo, apenas a biografia musical de nossa primeira grande compositora.

Ao contar a história da autora do Abre-Alas, Maria Adelaide traçou todo um painel do Brasil do começo do século, que se livrava da chaga da Escravidão e embarcava no sonho da República.

Sua adaptação de Os Maias, do patrício Eça de Queirós, transpôs os limites da crítica dura que o autor fez à sociedade lusitana de seu tempo. Também o Brasil estava presente ali na figura detestável do traficante de escravos.

A Muralha, baseada na obra de Dinah Silveira de Queirós, fez justiça a uma figura histórica a que o Brasil tanto deve - o bandeirante. Maria Adelaide pôde explorar neste seriado sua rara sensibilidade para observar os diferentes aspectos da história. As cenas dos sertanistas fazendo seus testamentos ficaram em nossas memórias como um testemunho de coragem e desapego, pois aqueles homens sabiam que iam partir, mas não sabiam se iam voltar. Cometeram erros e excessos, próprios da época, mas foram, a seu modo e há seu tempo, heróis da conquista e ocupação de um território que o Brasil só tinha nos mapas.

A levar à TV o romance A Casa das Sete Mulheres, Maria Adelaide soube tratar com equilíbrio um episódio que dividiu os brasileiros, em sangrenta guerra civil, para, ao final, uní-los ainda mais sob a bandeira fraterna de uma única Nação.

Nem farrapos nem imperiais, nem Bento Gonçalves nem Duque de Caxias. Brasil! eis a mensagem da autora.

E que já estamos num templo da arte, não custa comparar o seriado Um Só Coração a um grande painel do maior dos nossos pintores - Cândido Portinari. Num e noutro retratam-se a alma do Brasil. Ali desfilam não só os intelectuais do modernismo e sua obra atualizadora, o que não seria pouco, mas se apresenta aos nossos olhos a singularidade do povo brasileiro, em sua inteireza e combatividade. 
A valiosa contribuição dos imigrantes, as lutas 'sociais e políticos, a marcha da emancipação das mulheres, a luta pelos direitos trabalhistas, as greves, a modernização do país agrário-exportador em pólo industrial, a resistência à tirania eis o pano de fundo da História heróica de que esta cidade foi palco e agente.

Vemos ali o surgimento do movimento operário, primeiro com os anarquistas, depois com o Partido Comunista do Brasil. Tivemos a honra de contar em nossas fileiras com personalidades tão marcantes como Oswald de. Andrade e Patrícia Galvão, a Pagu, que nesta época deu à literatura brasileira o seu primeiro romance proletário, Parque Industrial.

A vila do Padre Manuel da Nóbrega e de José de Anchieta não poderia ter recebido, no aniversário de 450 anos, homenagem mais completa, histórica e poética, que esta prestada por Maria Adelaide Amaral e seus colaboradores com o seriado Um Só Coração.

Por tudo isso, nada mais justo que a formalidade se ajuste à realidade e a partir de hoje Maria Adelaide Amaral possa apresentar o documento e dizer: "Paulistana, com muito orgulho".

Para nós também.

Muito Obrigado.

Fundação Bienal de São Paulo, em 07 de abril de 2004.

Vereador Alcides Amazonas - Líder da Bancada do PCdoB

O texto ressalta a obra da autora e sua contribuição para o resgate da cultura e da história do Brasil. A entrega desse título pode ser entendida como uma forma de agradecimento da cidade pela homenagem prestada em Um Só Coração. Sem questionarmos os méritos da homenagem, observamos que nas idéias do discurso há semelhanças com o discurso adotado por diversos produtores das minisséries em outros momentos. Referimo-nos a uma confusão comum entre regional e nacional. Em alguns depoimentos e textos, autores, diretores e atores enxergam o regional como nacional. No caso do texto acima identificamos a passagem sobre A Casa das Sete Mulheres e a Revolução Farroupilha. Contraditoriamente, a autora recebe um título regional, por uma obra que exalta uma cidade, São Paulo, que teve resgatada na ficção elementos que compuseram sua imagem em diversos períodos históricos: terra dos desbravadores do Brasil, cidade do café, da indústria, do imigrante, constitu cionalista, "carro chefe da nação", vanguarda modernista, cidade que não pode parar, entre outros. 


\section{RESUMO DA MINISSÉRIE}

A minissérie contou a história da cidade de São Paulo entre os anos de 1922 a 1954. O fio condutor foi a vida de Yolanda Penteado, filha de uma rica família de aristocratas paulistas, típica representante da riqueza cafeeira e da tradição quatrocentona.

Yolanda estava sendo obrigada a se casar com um primo mais velho, Fernão, mas gostava de Martim. Este último era de uma classe social diferente e por isso a família não o aceitava. Entre vários encontros e desencontros, os dois se separaram e Yolanda se casou com Fernão.

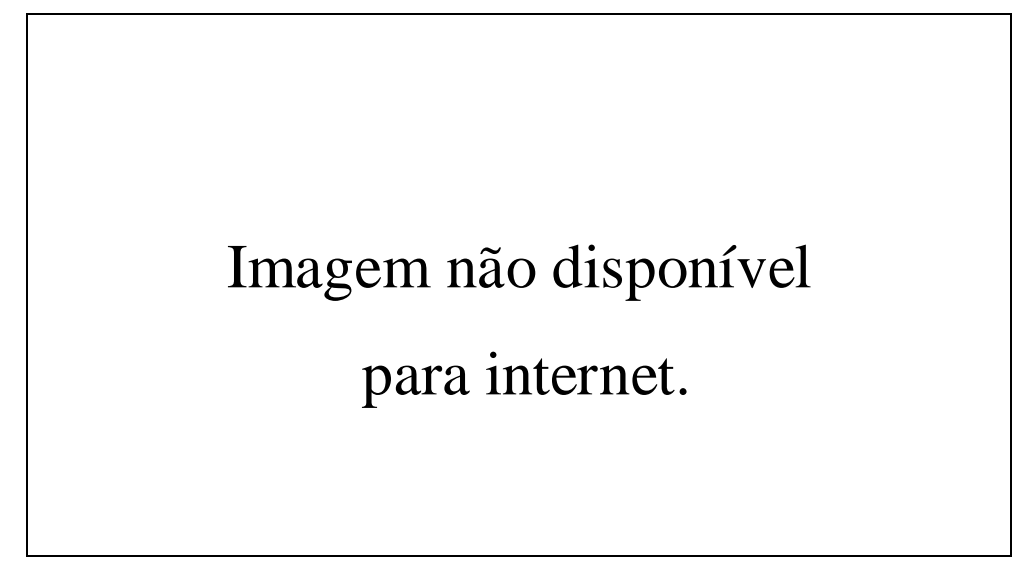

Yolanda (Ana Paula Arósio)e Martim (Erik Marmo).

Com o passar do tempo, o casamento não deu certo e ela se uniu ao industrial Francisco Matarazzo Sobrinho, o Ciccillo, e com ele se dedicou à criação e desenvolvimento de instituições de arte na cidade, como o MAM e as Bienais.

Por volta dos anos sessenta, Ciccillo e Yolanda se separaram e finalmente ela se uniu a Martim.

Paralelamente e se entrelaçando à história de Yolanda, outras tramas se desenvolvem. Uma das tramas que compunham o enredo era sobre a família de um cafeicultor, paulistano tradicional. A família do Coronel Totonho era formada por ele e seus filhos: Rodolfo, Maria Luísa, Bernardo, Maria Laura e Candinho. 


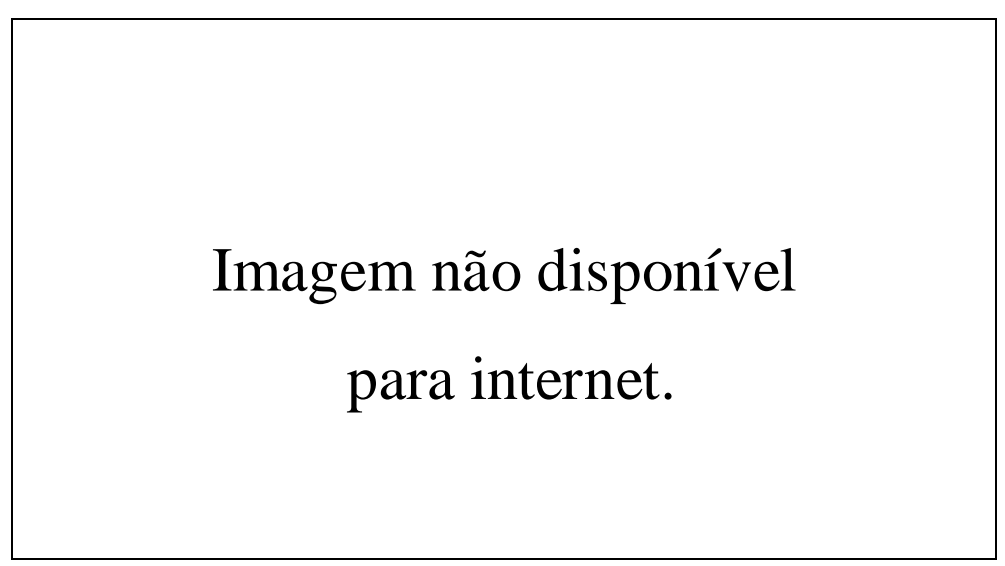

Família do coronel Totonho no início da minissérie.

O Coronel era um rico fazendeiro de café, arrogante e autoritário. Seu filho Rodolfo tinha idéias parecidas com as dele, mas os outros filhos não. Maria Luísa queria viver seus sonhos românticos, Bernardo tinha idéias revolucionárias e estava envolvido com os anarquistas, Maria Laura se interessava por literatura e Candinho, no início da história era uma criança. Tornou-se um rapaz de bom caráter, e um dos funcionários de Ciccillo Matarazzo.

Um outro núcleo de personagens era a família de Ernesto, um militante anarquista, que também tinha filhos: Ana (única adulta no início da minissérie), Uscha, Frederico e uma garotinha que morreu em um ataque da Revolução de 1924. As personagens Ernesto e Totonho eram opostas no caráter e nos ideais.

Há um núcleo de personagens históricas famosas, formado por artistas e seus patrocinadores: Tarsila do Amaral, Mário de Andrade, Oswald de Andrade, Menotti del Picchia, Guilherme de Almeida, Anita Malfatti, Paulo Prado, Olívia Guedes Penteado, senador Freitas Valle. Ao redor dessas personagens havia um conjunto de outras personagens, reais e fictícias que se relacionavam com elas.

A vida de todas as personagens foi marcada por vários acontecimentos do período como: greves operárias, a Semana de Arte Moderna de 22, a Revolução de 1924, a Coluna Prestes, a crise do café, a Revolução de 30, a Revolução de 32, o Estado Novo, a II Guerra Mundial, entre outros. 
De alguma forma todas as personagens se relacionavam com o universo cultural da cidade de São Paulo, quer por serem artistas, ou mecenas, e também, na forma de amigos e parentes dessas. Os grandes eventos sociais da minissérie giravam em torno do universo cultural da cidade no período, indicando o quanto questões políticas, econômicas e sociais podiam interferir nesse universo cultural.

A minissérie teve um grande número de personagens secundárias, porém históricas, que apareceram em poucas cenas, mas foram importantes como referência do período. Por seguir a ordem cronológica de acontecimentos, a obra acabou tendo um caráter didático, mesmo não sendo esta a intenção de seus autores.

Destacamos o uso do recurso de ter um narrador, que também foi personagem da história, Maria Laura, que contou a história.

Esta minissérie foi um texto original dos autores, porém não esteve livre de inspirações de obras dos próprios e de outras tantas sobre história e literatura do período. Foram inúmeras as fontes utilizadas por eles e seus colaboradores. 


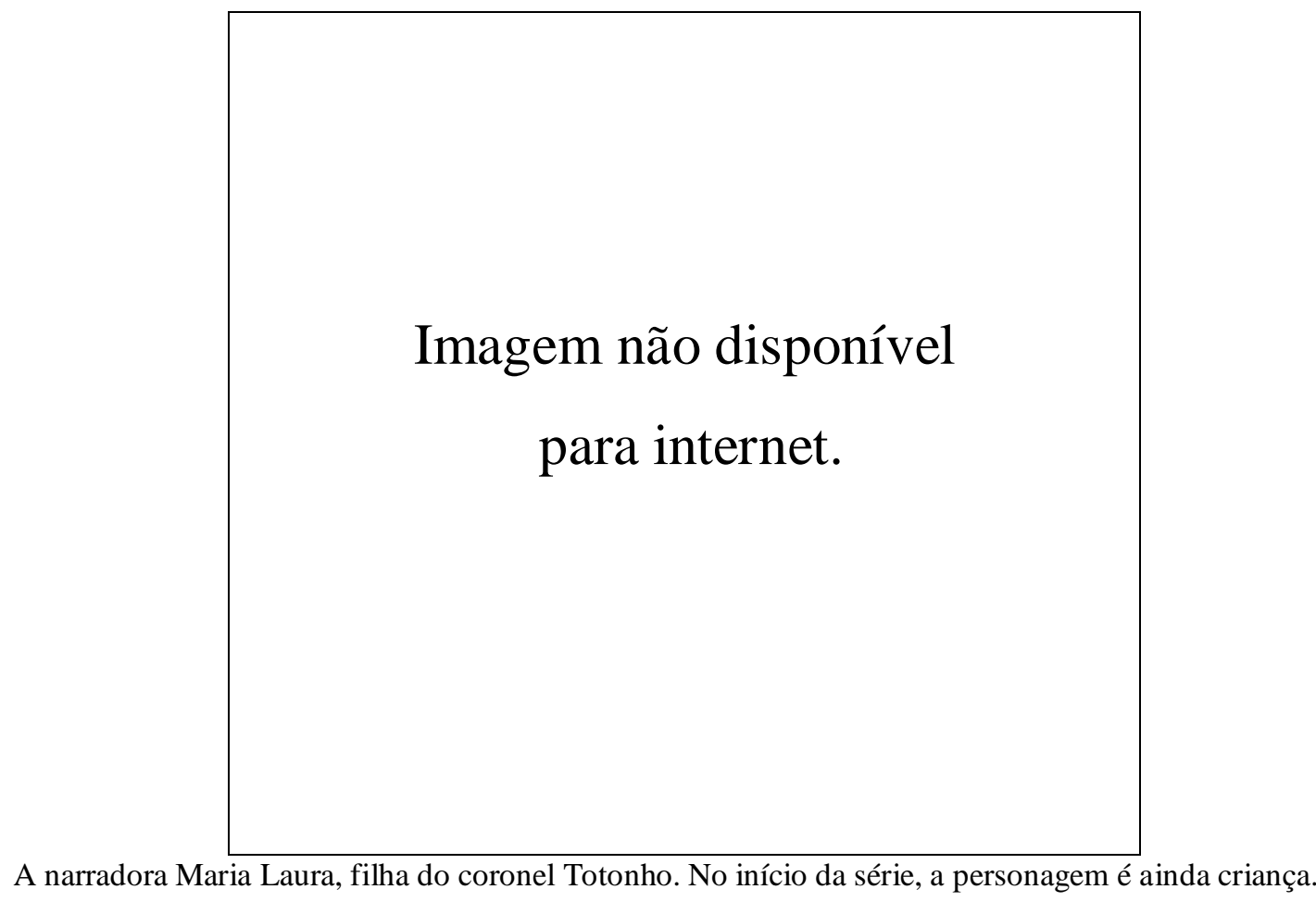

A edição em DVD foi feita pelos autores ${ }^{34}$, e é boa no que diz respeito à história ficcional. Porém, não investiu em entrevistas extras, apresentando apenas um apanhado de matérias do Vídeo Show.

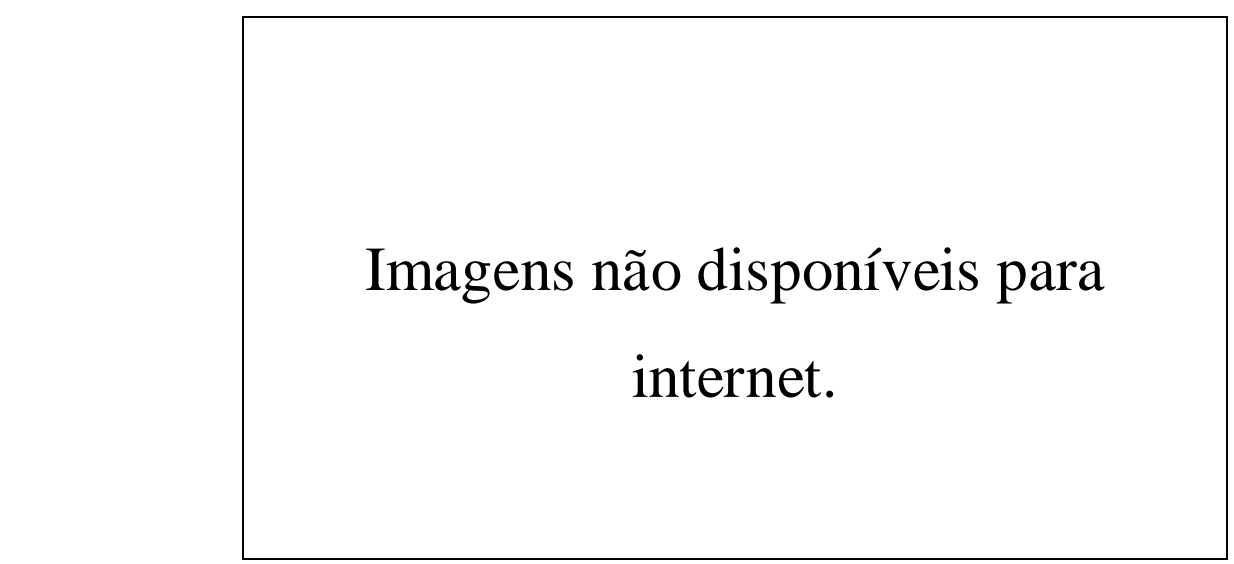

Os autores Maria Adelaide Amaral e Alcides Nogueira aparecendo na minissérie como figurantes.

\footnotetext{
${ }^{34}$ Entrevista concedida pela autora Maria Adelaide Amaral para a pesquisa.
} 


\section{CAPITULO IV - O PASSADO REPUBLICANO RECRIADO}

Nosso objetivo neste capítulo é indicar através de passagens da minissérie $U m$ Só Coração como o conhecimento histórico foi utilizado. Diferente da minissérie $A$ Muralha, que tinha como fonte principal de inspiração a obra literária, Um Só Coração foi um texto original de Maria Adelaide Amaral, que teve como parceiro nesta obra Alcides Nogueira. Assim, nossa análise também será diferente, pois o uso de fontes para a construção desta ficção foi diverso.

Apresentaremos alguns aspectos do uso de biografias, enfatizando Yolanda Penteado, a Revolução Constitucionalista de 1932 e temas para outros trabalhos.

\section{UMA VIDA SE CONFUNDINDO COM A HISTÓRIA DE SÃO PAULO - YOLANDA PENTEADO E O DESENVOLVIMENTO DAS ARTES}

Quando Maria Adelaide Amaral decidiu contar a história de São Paulo, enfatizando a vida cultural da cidade no século XX, escolheu Yolanda Penteado como fio condutor para sua história:

"E tem mais, a heroína e eixo principal da minissérie é Yolanda Penteado que assistiu e agitou todos esses eventos. Mas afinal quem era Yolanda Penteado? Uma mocinha que começa a vida como Sissi, tem sua fase Scarlett O`Hara, e termina a vida como tia Meme. (...).,"1

Referências às heroínas de clássicos do cinema como os filmes Sissi e E o Vento Levou indicam-nos uma tendência a romantização da história. A construção narrativa ficcional levou Yolanda a cenas dignas de Scarlett, mas há um detalhe que antecede a imaginação dos autores. A autobiografia de Yolanda possui passagens romantizadas. A comparação, provavelmente, veio de uma visão antecedente e pré-estabelecida da personagem.

A Yolanda Penteado real nasceu em 1903 na Fazenda Empyreo, em Leme, São Paulo. Filha da importante família aristocrata paulista Penteado, sendo seus pais Juvenal e Guiomar Penteado. Yolanda ouviu na infância, por sua mãe, a história de seus

\footnotetext{
${ }^{1}$ Tuna Dwek. Maria Adelaide Amaral: a emoção libertária. São Paulo: Imprensa Oficial do Estado de São Paulo: Cultura-Fundação Padre Anchieta, 2005, p.252.
} 
antepassados paternos, entre os quais se encontravam João Ramalho e Bartira. ${ }^{2}$, o que a caracterizava como uma aristocrata da terra. E assim, ela cresceu, vivendo em um mundo "cor-de-rosa", como o título de sua biografia diz.

Como era comum em famílias proprietárias de fazendas de café, os casamentos eram realizados entre famílias aparentadas e de mesma origem social. Assim, Yolanda se casou com Jayme da Silva Telles ${ }^{3}$, que inspirou, na ficção, a personagem Fernão ${ }^{4}$.

Mas a moça possuía outros admiradores, como o aviador Santos Dumont:

"Seu Alberto, de fato, me fazia a corte: trazia-me bombons, flores, levava-me a passear. As pessoas que o conheciam melhor diziam que, quando ele me via, ficava elétrico.(...)". 5

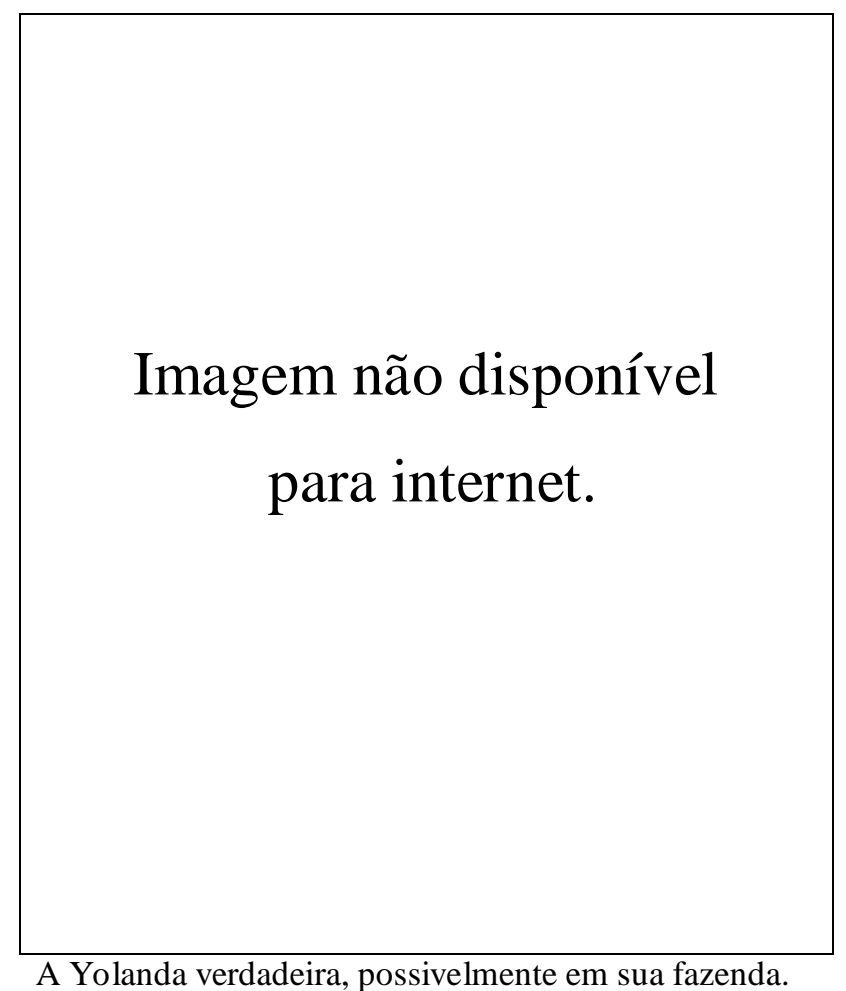

Santos- Dumont fazia parte do círculo das famílias cafeicultoras e era cunhado de uma de suas tias.

\footnotetext{
${ }^{2}$ Antonio Bivar. Yolanda. São Paulo: A Girafa Editora, 2004, p.20.

${ }^{3}$ Yolanda Penteado. Tudo em cor-de-rosa. Rio de Janeiro: Nova Fronteira, 1976, p. 49.

4 Como Yolanda também tem um irmão com nome de Jayme, o nome do marido foi alterado, possivelmente para não confundir o público.

${ }^{5}$ Yolanda Penteado. Tudo em cor-de-rosa. Rio de Janeiro: Nova Fronteira, 1976, p.58.
} 
Assis Chateaubriand foi um outro "apaixonado", segundo a biografia de Chatô, editada recentemente. ${ }^{6} \mathrm{O}$ episódio é comum aos dois livros: ocorreu na casa de Alfredo Pujol, após a apresentação de Yolanda, em uma peça, $O$ contratador de Diamantes:

“...nessa mesma noite, conheci, na casa do dr. Alfredo Pujol, um rapaz que não era bonito e que, depois, me pediu em casamento sem resultado.. ele veio a se tornar o melhor amigo que eu tive na vida. Chamava-se Francisco de Assis Chateaubriand Bandeira de Mello e já era muito conhecido nos meios jornalísticos como Assis Chateaubriand."

"Iolanda (sic) ainda estava vestida à Luís XV, com uma peruca coberta de talco sobre a cabeça, quando conheceu Chateaubriand. Segundo ela mesma diria depois, 'ele ficou tonto' diante de sua beleza. Iolanda revelaria também, que apesar de tê-lo achado 'um rapaz não muito bonito', tinha ficado hipnotizada com sua conversa. Chateaubriand convidou-a para caminharem juntos pelos jardins e foi ali mesmo, um par de horas, após conhecê-la, que lhe propôs casamento. Ao recusar de chofre, Iolanda não imaginava que aquele seria apenas o primeiro pedido - apaixonado por ela até o fim da vida, Chateaubriand voltaria a repeti-lo, sempre em vão, dezena de vezes. Ao retornar ao Rio e comentar em uma roda da livraria Leite Ribeiro que havia recebido um 'não' de Iolanda - 'uma verdadeira princesa austríaca', dizia - Chateaubriand ouviu uma confissão do aviador Alberto Santos Dumont:

- A recusa dela ao seu pedido me consola. Quando Iolanda rejeitou a minha proposta de casamento, meses atrás, achei que fosse por causa da diferença de idade, pois sou trinta anos mais velho que ela. Mas se ela disse não a você, que é um jovem, está tudo explicado: Iolanda não deve gostar de homens que andam com a cabeça nas nuvens, como nós dois."

Na ficção, as personagens inspiradas em Chatô e Santos-Dumont também eram apaixonadas por ela e sempre a cercavam de carinho e atenções, tentando também ajudá-la. Em alguns momentos, Chatô a atrapalhava, pela ansiedade de ajudar, ou mesmo por egoísmo, para conseguir uma oportunidade de conquistá-la. Eles discutiam muito, mas ele estava sempre presente na vida dela.

Diferente das biografias reais, o Chatô e a Yolanda da ficção conheceram-se na presença de Santos-Dumont. A jovem Yolanda marcou um chá com seu amigo "messieur Santos" em um hotel. Chatô, sem grande cerimônia, chegou à mesa, apresentando-se e já comentando o casamento de Yolanda, o que a deixou profundamente irritada, indicando uma inicial antipatia pelo futuro amigo. ${ }^{9}$ Nesta passagem também observamos como a elite paulistana, no início da década de 20 , do

\footnotetext{
${ }^{6}$ Fernando Morais . Chatô: o rei do Brasil, a vida de Assis Chateaubriand. São Paulo: Companhia das Letras, 1994.

${ }^{7}$ Yolanda Penteado. op. cit., p.73.

${ }^{8}$ Fernando Morais . op.cit., p.106 e 107.

${ }^{9}$ Maria Adelaide Amaral \& Alcides Nogueira. Um só coração. Globo Vídeo, 2004 - Disco 1
} 
século passado, gostava de copiar hábitos europeus, como falar em francês com sotaque e tomar chá, hábito dos ingleses.

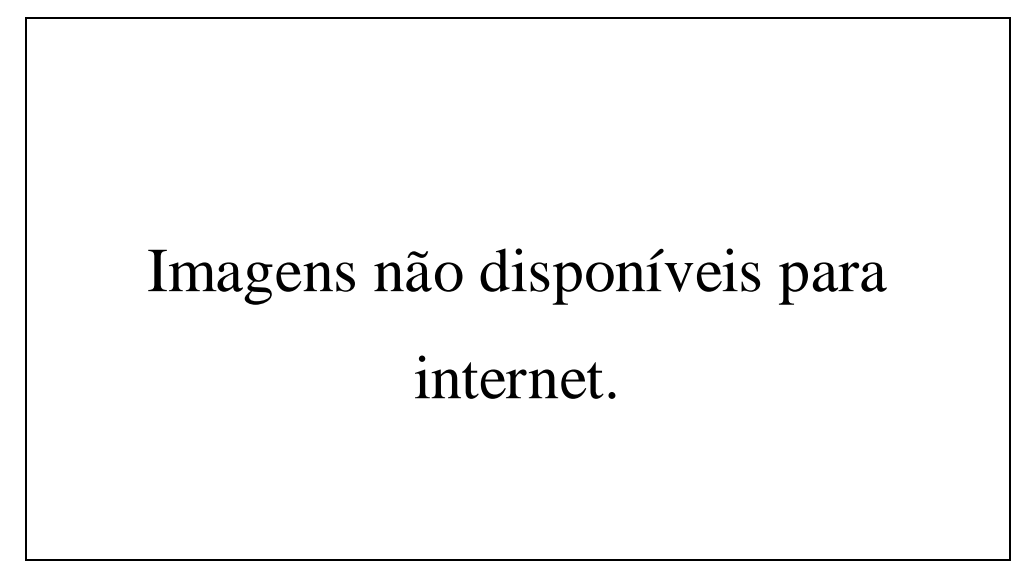

Chatô e Santos-Dumont da ficção.

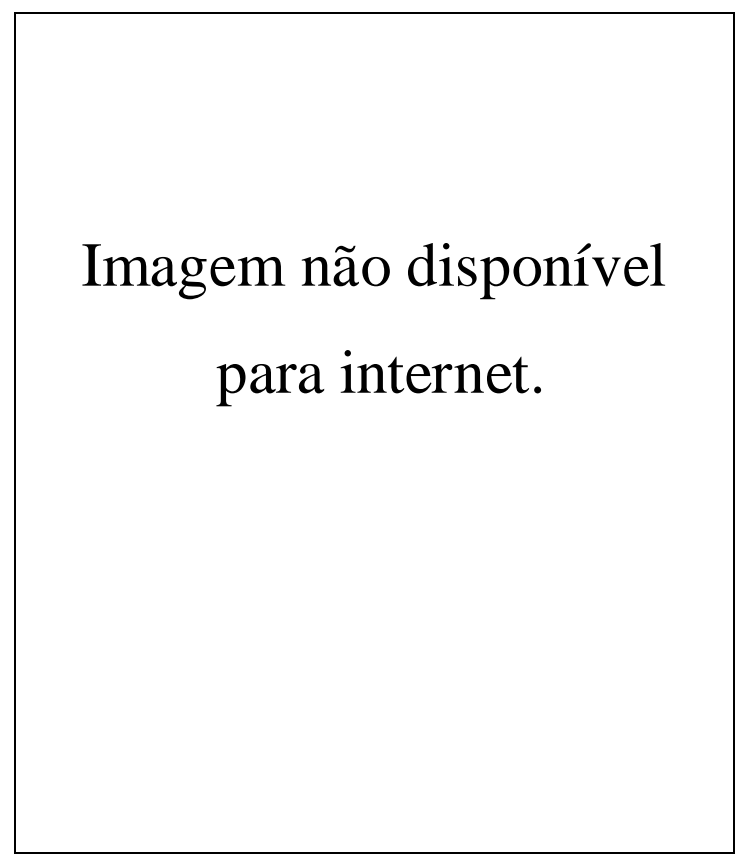

Chatô e JK na II Bienal (1953-1954).

Voltando a Yolanda, a mocinha da ficção encenou também uma peça. Esta passagem nos serve para introduzir a Villa Kyrial, residência do Senador Freitas Valle, mecenas das artes na época. É nessa apresentação que ela conhece seu amor na fícção, 
Martim Paes de Almeida. Sabemos que Yolanda era considerada uma das moças mais atraentes de seu tempo, por diversos amigos e contemporâneos. Ela possuía carisma e era avançada em diversos aspectos. Martim foi uma personagem ficcional, que ao nosso ver, pode ser uma fusão de muitos dos possíveis enamorados da verdadeira Yolanda.

Ao contar a história de Yolanda, é contada também a história de Chatô e SantosDumont. Este último se mata durante a Revolução de 1932. Chatô acompanha Yolanda todo o período da história da minissérie, que não explora a sua vida particular. Sua presença era constante, mas sem vida própria, sempre cortejando Yolanda. Contudo, há informações sobre seu crescimento profissional, com seus jornais, os Diários Associados e depois com a TV Tupi.

A apresentação do Chatô ficcional, em alguns momentos, tornou-o vilão, com os atos de atacar pessoas em seu jornal e ameaçá-las, chantageando em troca de dinheiro. Mas era uma personagem criativa e com humor.

A Villa Kyrial foi bastante retratada no início da minissérie. Por lá circulavam várias personagens importantes, em especial, os artistas. A personagem do senador participa de toda a história:

"Freitas Valle, que se confunde com o próprio espaço do seu salão, foi poeta simbolista, professor de francês, advogado, perfumista, gourmet mecenas, deputado e senador estadual. Como legislador, teve uma atuação voltada para a questão educacional e o ensino das artes, sendo um dos principais responsáveis pelo Pensionato Artístico do Estado de São Paulo. Graças a ele, inúmeros talentos tiveram oportunidade de se revelar, em nomes como Anita Malfatti, Victor Brecheret, Leonor Aguiar, João de Sousa Lima e Francisco Mignone, por exemplo, que puderam prosseguir os estudos em centros europeus.

A importância da Villa Kyrial torna-se tanto mais evidente se levarmos em conta o fato de que São Paulo, apesar de se haver tornado um dos principais pólos industriais, comerciais e políticos do país, praticamente não contava com instituições culturais. (...).

Mas a Villa Kyrial também deve ser vista como expressão de uma elite que pretendia assimilar as mudanças em curso na virada para o século $\mathrm{XX}$ e, simultaneamente, preservar o status e privilégios. Em meio a profundas metamorfoses, essa elite procurava alimentar um sentimento de continuidade, mantendo hábitos aristocráticos e reforçando a tradição. Para se legitimar, espelhava-se na França e na Inglaterra, reconhecidas como paradigmas de cultura superior na Europa. De lá tomava emprestados valores a serem emitidos com o objetivo de construir uma imagem de si mesma a mais próxima possível do original franco-inglês.",10

${ }_{10}$ Marcia Camargos. Villa Kyrial: crônica da Belle Époque paulistana. São Paulo: Editora SENAC São Paulo, 2001, p.16. 
Marcia Camargos ${ }^{11}$ realizou o estudo sobre a Villa Kyrial, que foi utilizado na elaboração da minissérie, especialmente para o período inicial da história e não apenas no tema das artes. A passagem acima indica algumas características da elite paulistana e do viver em São Paulo, que foram aproveitadas.

Diversos artistas que passaram pela Villa Kyrial não foram retratados na minissérie, e alguns dos eventos descritos na narrativa televisiva não estavam na obra histórica. O livro foi utilizado como fonte de inspiração, referência e para levar ao conhecimento de um público, supostamente menos esclarecido sobre o assunto, informações sobre existência da casa e do mecenas das artes.

Outro importante momento artístico do início da minissérie foi a Semana de Arte Moderna de 1922, que acabou servindo de cenário para um encontro proibido da Yolanda ficcional e Martim. Não há registro da presença da Yolanda real no evento, pois era muito jovem, com apenas dezenove anos. De acordo com Antonio Bivar, ela passou a conviver com os artistas modernistas após a Semana. ${ }^{12}$

A Yolanda ficcional foi aos poucos mostrando seu envolvimento com os artistas. Ela era aluna de Mário de Andrade no conservatório e amiga de Paulo Prado. Porém, ao nosso entender, a minissérie indicava sua tia, Dona Olívia Guedes Penteado, como a grande mecenas e amiga dos modernistas. Yolanda, como sobrinha e moça da sociedade, circulava nos meios e conhecia pessoas, porém só passou a demonstrar um grande envolvimento com as artes quando uniu-se a Ciccillo Matarazzo.

No período inicial da minissérie, ela se casou com o primo Fernão e tentou engravidar; salvou crianças baleadas na rua, durante a Revolução de 1924 e continuou com sua vida aristocrática até 1930, quando a crise do café mudou sua situação econômica.

A Yolanda real levava uma vida mais tranqüila, de acordo com as suas memórias. Entre viagens com o marido e encontros com personalidades importantes, parece que algo muda com o fim do casamento:

"No início de 1934, ficamos seis meses no Rio. Quando voltamos para São Paulo, senti que havia acabado um período muito bonito de minha vida.

Como tudo é uma questão de tempo, se transforma constantemente, eu e Jayme nos separamos.

\footnotetext{
${ }^{11}$ De acordo com entrevista de Maria Adelaide Amaral para esta pesquisa, Marcia Camargos foi uma de suas consultoras.

${ }^{12}$ Antonio Bivar. Yolanda, op.cit.,, p.88 a 91.
} 
A separação foi difícil, pois continuava a ter pela família Silva Telles, uma amizade enorme e eles por mim. Esperei sete anos para que Jayme me desse o desquite." 13

A Yolanda na minissérie começou a mudar com a ameaça de pobreza da família, após a quebra da bolsa de Nova York e a crise da cafeicultura, quando se dedicou ao trabalho para reerguer a fazenda e Fernão não queria colaborar. Além disso, ele mantém um relacionamento com uma amiga de Yolanda, Elisa, e ela os encontra juntos em sua própria cama. O roteiro segue o de folhetim: mocinha lutadora, homem vilão e uma traição.

A separação ficcional aconteceu antes da real. No período que a ficção retratou a Revolução de 1932, o casal já estava separado e o episódio é explorado em alguns desentendimentos entre Fernão e Yolanda.

A origem do episódio da minissérie não é importante, mas contém os elementos que alimentam a ficção, por isso mesmo é declaradamente a Yolanda inspirada na verdadeira. Para os produtores, importa que o público o conheça e relembre o resultado de suas obras, que beneficiaram a vida cultural da cidade.

Entre reerguer a fazenda com uma plantação de algodão e a criação de bicho da seda, as Yolandas conheceram aquele que foi seu companheiro de muitos anos, Ciccillo Matarazzo:

"Conheci Ciccillo num jantar na casa de Mariângela, sua irmã.

Simpatizamos muito um com o outro. Ciccillo quis conhecer mamãe. Passados uns dias, fomos a São Vicente visitá-la. Mamãe gostou dele, ficaram logo amigos.

Em breve partíamos para Roma, onde encontramos May Pezzi, boa amiga, tão cheia de vida. Os programas eram alegres. Ciccillo, porém precisou fazer uma pequena intervenção cirúrgica. Inverno, os hospitais estavam mal aquecidos por falta de combustível.

Maurício Verdier telegrafou do México, comunicando que tinha obtido aquele documento convencional. Tinha-nos representado no suposto casamento mexicano.

De Roma seguimos para Paris, onde ficamos um mês no Plaza Athenêe. Ciccillo, infelizmente ficou acamado. A conselho de seu médico francês fomos a Milão consultar um grande professor italiano, da sua confiança.

Ele recomendou a Ciccillo uma estada em Davos.

Tudo era bonito e sincero entre Ciccillo e eu.

Recordações tão boas do meu ex-sogro Sr. Andréa, nos queríamos tanto!

Batíamos bons papos. O mesmo acontecia com mamãe e Ciccillo, com Virgínia e com a sua família. Afinal com a família Matarazzo foi...quase tudo em cor-derosa." $" 14$

\footnotetext{
${ }^{13}$ Yolanda Penteado. op. cit. p.115.

${ }^{14}$ Yolanda Penteado. op. cit. p.167.
} 


\section{Imagens não disponíveis para internet.}

Yolanda e Ciccillo.

\section{Imagens não disponíveis para internet.}

$\mathrm{Na}$ ficção, Ciccillo e a Yolanda viveram muitos anos entre idas e vindas antes de oficializarem a união. A ida para a Suíça foi para tratamento de uma doença no 
pulmão ${ }^{15}$, mas rendeu os grandes feitos do casal. Ciccillo começou a presentear Yolanda com as obras que seriam depois do acervo do MAM. Aí Yolanda começou a se interessar pelos artistas e investir no trabalho pela cultura, inspirada na vida de sua tia Olívia.

As etapas de elaboração do MAM e das primeiras exposições da Bienal foram retratadas na ficção em conversas e alguns acontecimentos. Não foram feitas reconstituições, exceto para o quadro Guernica, de Picasso, que veio para a II Bienal. As cenas são narradas por Maria Laura, com fotografias de época, em sua maioria pertencente ao Arquivo Histórico da Fundação Bienal.

Vários acontecimentos culturais da cidade foram retratados também de maneira rápida: exposições, grupos de pintores (Santa Helena), grupos de críticos (Revista Clima), a criação do TBC e da Vera Cruz, com investimento de Ciccillo, entre várias citações de acontecimentos e personagens da cultura paulista.

Especialmente no período que compreende a última década retratada, percebemos uma aceleração dos acontecimentos culturais. Muito diferente do começo da minissérie, que a narrativa era mais lenta e focava mais os aspectos políticos, econômicos e sociais. Um exemplo disso é que boa parte dos diálogos da peça Tarsila, de Maria Adelaide, foi aproveitada. As personagens ligadas ao modernismo, também tiveram suas histórias mais desenvolvidas no início da trama, sendo concluídas as histórias de Tarsila, Oswald, Anita e Mário, que morre no decorrer da minissérie.

Porém, eles já não pertenciam ao grupo de artistas "de vanguarda", na época. A Bienal buscava inovações. Outros acontecimentos culturais ocupavam o lugar deles. Jovens escritores e críticos surgiram. Até um jovem Antonio Candido ficcional apareceu na minissérie, evocado pelo Oswald de Andrade ficcional, entre os "chato boys". ${ }^{16}$ Não só ele, mas também Jorge Amado, Lasar Segall, Blaize Cendrás, Flávio de Carvalho, Villa-Lobos, Geraldo Ferraz, Cacilda Becker, Eliane Lage e muitos outros apareceram como personagens da ficção. E Tônia Carrero e Paulo Autran apareceram, interpretando pessoas que comentavam sobre eles no início da carreira.

A minissérie foi uma grande homenagem ao universo cultural da cidade no período e finalizou com a festa de descasamento de Ciccillo e Yolanda, que serviu para apresentar os nomes da cultura paulistana, posteriores ao período da minissérie.

\footnotetext{
${ }^{15}$ A doença possivelmente era tuberculose, mas não está dito diretamente na ficção, ou em qualquer das obras biográficas consultadas, como sugere Antonio Bivar. op.cit p. 213.

${ }^{16}$ Maria Adelaide Amaral \& Alcides Nogueira. op. cit. - Disco 5
} 
Antes dessa festa houve a comemoração do IV Centenário e sua chuva de prata. Alguns anos depois, houve a doação da coleção de obras do acervo do MAM/SP à Universidade de São Paulo e a festa de descasamento. Aí finalmente, a Yolanda ficcional vai viver seu amor por Martim.

A Yolanda Penteado real viveu todo esse período. Por essa razão, podemos considerá-la uma boa escolha como personagem para conduzir tantos acontecimentos.

Trabalhou muito nesses eventos, viveu como descreveu com Ciccillo e após isso, resolveu fazer um livro de memórias, contando sua trajetória, que se por um lado pode fascinar, ao vê-la convivendo com tantas pessoas interessantes, por outro lado leva-nos ao questionamento: mas será que foi assim mesmo? A maturidade dá tanta serenidade para contar a sua vida?

Não nos cabe fazer a cobrança de uma reflexão crítica sobre seu papel na sociedade de então. Seu relato de memórias é válido; é a percepção de uma senhora que viveu oitenta anos e viu transformações importantes na cidade de São Paulo: de família aristocrática, viu a decadência do café e o crescimento industrial e urbano; viveu praticamente todo o século XX e suas grandes personalidades brasileiras e estrangeiras. E teve a oportunidade de deixar uma obra cultural para a cidade.

Hoje, apesar dos problemas e do questionamento ao trabalho e funcionamento de instituições culturais como o MAM/SP e a Fundação Bienal, não é possível desmerecer o valor de ambas. Na prática, não importa a experiência real de Ciccillo e Yolanda, o fato reconhecido consensualmente é que eles prestaram um serviço para a cidade, dotando-a de equipamentos culturais inovadores. 


\section{Imagem não disponível para internet.}

Ciccillo e JK, vendo Guernica, de Picasso, durante a II Bienal.

\section{Imagem não disponível para internet.}

Público aguarda a abertura da II Bienal. 


\section{A REVOLUÇÃO CONSTITUCIONALISTA DE 1932 - ORGULHO DE SER PAULISTA}

A representação da Revolução de 1932 foi um dos momentos mais marcantes da minissérie e retratou elementos da identidade e ufanismo do paulista.

Entre as questões do governo Vargas, destacou-se o episódio da Revolução Constitucionalista de 1932, que foi desenvolvido em diversos capítulos, envolvendo grande parte das personagens, que manifestavam opiniões sobre o mesmo. Como a principal fonte para nossa pesquisa é o material editado para o $\mathrm{DVD}^{17}$, devemos comentar que o aspecto histórico foi privilegiado em relação a algumas tramas da ficção, e aparentemente não houve cortes em relação ao que foi transmitido pela minissérie. O recorte do período para a análise vai do momento no qual eclode a revolução até seu término. Aspectos prévios e posteriores não são considerados.

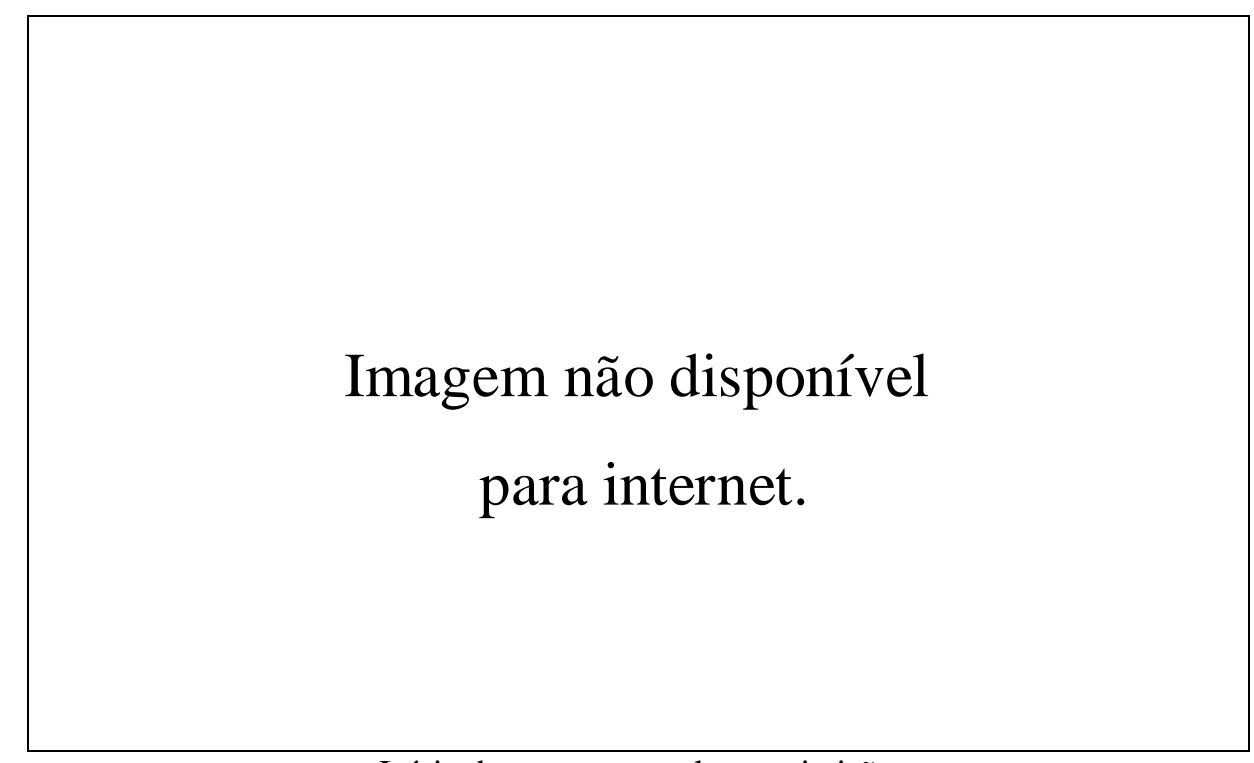

Início dos protestos pela constituição.

\footnotetext{
${ }^{17}$ Maria Adelaide Amaral \& Alcides Nogueira. Um só coração. Globo Vídeo, 2004.
} 
No conjunto de cenas foram levantados os seguintes temas: o discurso do narrador (Maria Laura) ${ }^{18}$, conversas entre as personagens demonstrando opiniões diversas sobre a revolução, o desenvolvimento do movimento, a luta nas trincheiras, o apoio da população, a utilização do avião como arma, as prisões e a conscientização da derrota.

Como escreveu Holien Gonçalves Bezerra a respeito da literatura sobre o tema:

"A literatura criada em torno da Revolução de 1932 é volumosa e variada. É significativa a produção de memórias, contendo considerações emotivas, afirmações regionalistas, críticas duras ou narrativas pormenorizadas de 'feitos gloriosos'. “19

Não foi nosso objetivo fazer uma discussão historiográfica sobre 32, mas indicar alguns aspectos da revolução e como eles são tratados na ficção. Um dos mais relevantes foi a maneira emocional com que o episódio foi tratado, como coloca a matéria do jornal Folha de S. Paulo sobre o assunto:

“(...). Três ou quatro vezes por semana, bem tarde da noite, a Globo transmite Um só coração, que nos leva, em certos momentos, a verdadeiras evocações do tempo em que ser patriota não era vexame nem politicamente incorreto. Bem tarde da noite, quase sempre sozinhos, sentimos estufar o peito de orgulho de viver em São Paulo, herdeiros da Revolução Anarquista de 24 (sic) e da Constitucionalista de 32. Como quem não quer nada, os autores atrelam à fé revolucionária a possibilidade de inclusão de todos os habitantes desta cidade que recebe migrantes desde o início do século 20. Em certos momentos, os patriotas tornam-se torcedores - quando vibram, gritam e constroem estrofes cadenciadas de enaltecimento à causa. O patriota paulista de Maria Adelaide e Alcides é um brasileiro. E é para todo o Brasil que clama que seja feita uma Constituição. Cenas que poderiam ser pueris ganham peso quando recitadas em paulistês. É o credo religioso que ganha novas palavras: 'Creio em São Paulo e na Constituição...'. Vibra a corda certa do coração quando outros arremedos de poesia pátria esbarram com o sagrado." 20

Podemos citar vários exemplos que comprovam o discurso emotivo. A personagem Bernardo Sousa Borba, filho de família de cafeicultores decadentes, anarquista, justifica sua luta na causa paulista:

\footnotetext{
18 Maria Laura é a narradora da minissérie e no final há uma sugestão de que ela escreva um livro, contando sua história, da qual participam as personagens importantes da cidade.

${ }^{19}$ Holien Gonçalves Bezerra. O jogo do poder: Revolução paulista de 32. São Paulo: Moderna, 1988, p.9

${ }^{20}$ Ana Verônica Mautner. "Pátria amada". Folha de S. Paulo, 18/03/2004, c. Equilíbrio, p.12.
} 
"Quando eu vi o Mário Martins cair morto na minha frente, eu descobri que era paulista. A minha batalha é aqui."21

Abaixo, Jayme, Candinho e Bernardo, personagens da minissérie, são partidários da causa paulista.

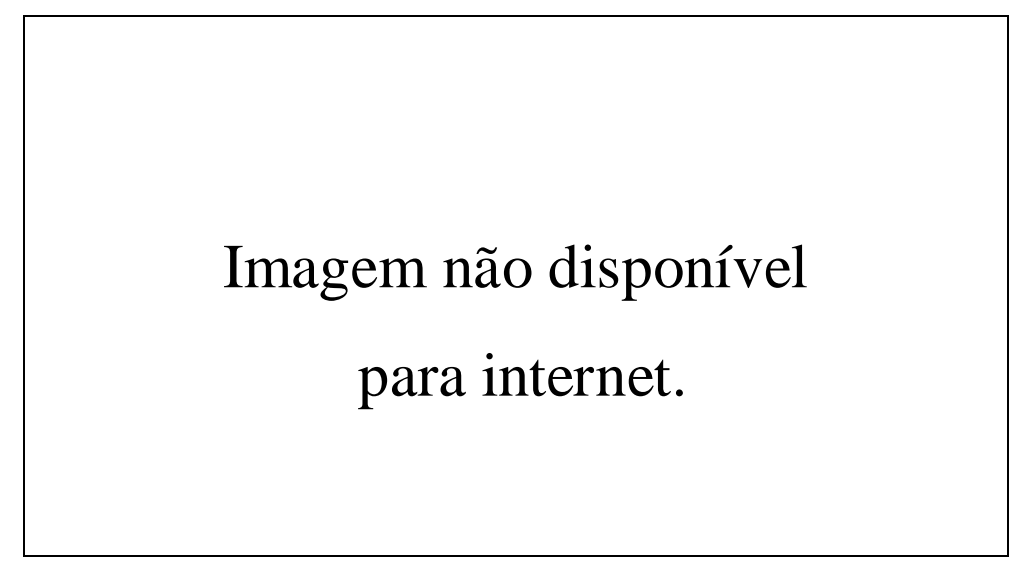

A protagonista Yolanda também demonstrou grande envolvimento na causa paulista. Como a heroína da ficção, circulava em todos os núcleos, defendia as causas mais nobres e a revolução é uma delas.

$\mathrm{Na}$ confrontação da ficção com a fonte e os acontecimentos históricos, a verdadeira Yolanda não estava no Brasil quando teve início a Revolução Constitucionalista. Estava voltando de uma viagem à Europa com seu primeiro marido, permanecendo com vários paulistas no Rio de Janeiro. Como ela mesma descreveu em sua autobiografia:

"Passamos dias aflitos no Rio. As cartas, censuradas. Uma ou outra que
recebíamos, eram trazidas pelos raros portadores vindos de São Paulo. Pedia aos
meus amigos diplomatas do Rio que remetessem minhas cartas."
"Pouco a pouco, fomos compreendendo o que se passara enquanto estávamos
na Europa. Getúlio era chefe do Governo Provisório. Os paulistas queriam a
Constituição prometida pelos revolucionários de 30 . A nove de julho, começou
a Revolução.(...)."22

A Yolanda da ficção, separada de seu primeiro marido, partiu de São Paulo para o Rio justamente para discutir seu desquite. Ao encontrá-lo questionou-o por não estar

\footnotetext{
${ }^{21}$ Maria Adelaide Amaral \& Alcides Nogueira. Um Só Coração (DVD). Globo Vídeo, 2004. - Disco 4.

${ }^{22}$ Yolanda Penteado. Tudo em cor-de-rosa, op. cit., p.107.
} 
lutando por São Paulo. E hospedados no mesmo hotel estavam Paulo Prado, sua esposa e sobrinha, também partidários de São Paulo. Eram muito ligados com a família Guinle, do Rio, o que é inspirado no relato de Yolanda.

$\mathrm{Na}$ articulação entre ficção e história, os autores aproveitaram a rivalidade ficcional entre Yolanda (paulista) e Gilda (carioca), já que ambas disputavam o amor do mesmo homem, para demonstrar também a rivalidade política. Em cena na qual estão reunidos paulistas e outros brasileiros, Gilda acusa São Paulo de querer se separar do Brasil. Yolanda responde:

"É mentira. É desculpa de Getúlio para nos agredir e desmoralizar. São Paulo revoltou-se contra o governo porque deseja uma Constituição para o Brasil. São Paulo jamais quis se separar."23

Por esta fala, a Yolanda fictícia foi levada à prisão, na qual encontra seu amigo Assis Chateaubriand.

Um dos momentos mais emocionantes na minissérie foi no início da revolução quando Martins, Miragaia, Dráusio e Camargo são mortos. Os quatro estavam envolvidos com outras personagens, algumas delas centrais, trazendo conseqüências para o andamento da trama, como foi indicado na fala de Bernardo acima citada.

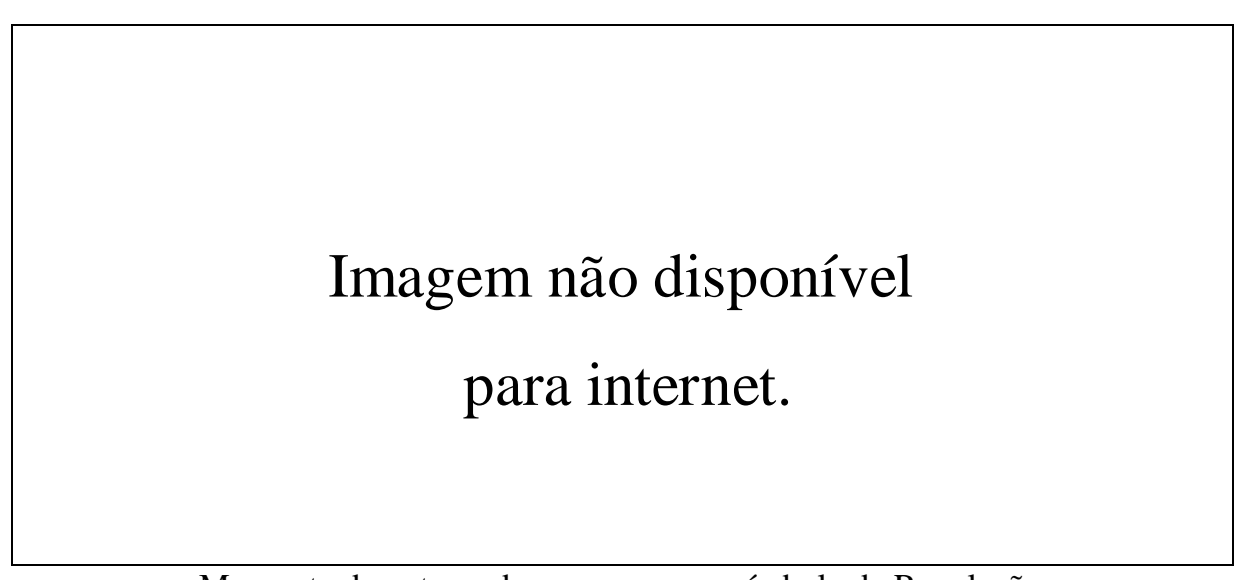

Momento do enterro das personagens-símbolo da Revolução.

\footnotetext{
${ }^{23}$ Maria Adelaide Amaral \& Alcides Nogueira. op. cit. Disco 4.
} 
Numa das cenas de alistamento dos soldados, apareciam os estrangeiros acolhidos em São Paulo, demonstrando seu comprometimento com a causa. É o que se percebe no diálogo entre Samir (libanês) e Joaquim (português):

"São Paulo me acolheu, assim como acolheu o senhor. Devo tudo a esta cidade e a este povo. Estamos cumprindo com o nosso dever, senhor Joaquim."24

Nesse momento pareceu que o imigrante foi contagiado pelo espírito do bandeirante e se tornou um verdadeiro paulista: paulistas adotivos, aderem à causa revolucionária, e, se antes sofriam preconceitos por sua origem, tornaram-se necessários para a luta.

Todos eram paulistas. A imagem passada era de que ricos ou pobres, imigrantes ou aristocratas, brancos ou negros, todos defendem a revolução pela Constituição e contra os desmandos do ditador. Os que discordavam, faziam-no mais por perceber os riscos que São Paulo corria de ficar isolado e não receber o apoio do resto do país, do que por estar contra a causa. As diferenças sociais não foram trabalhadas durante a revolução.

O discurso adotado na minissérie correspondia bem ao discurso da elite paulista da época. Como colocou Katia Abud:

"O apelo à luta armada contra a Ditadura devia se fazer em nome de uma unidade de interesses, que não existia na sociedade paulista. Havia sim, uma unidade nas camadas dominantes paulistas - mas as questões nas quais se centralizavam a oposição ao governo Vargas, não sensibilizavam outras camadas da população como a classe operária, vista pela vista dominante, como uma sempre presente ameaça. Era necessário que a população como um todo estivesse envolvida - era preciso o apoio de toda a população e por isso era preciso convencê-la que não eram as camadas conservadoras que lutavam por um projeto político, mas São Paulo que desafiava a ditadura em nome do Brasil; São Paulo que se erguia por uma Constituição para o Brasil. Havia sempre uma busca de unidade, de universalização do particular, omitindo do seu ideário a divisão de classes da sociedade." ${ }^{25}$

A minissérie também mostrou o apoio da população à revolução: as mulheres doavam suas jóias e se dedicavam a confeccionar os uniformes dos soldados.

\footnotetext{
${ }^{24}$ Idem.

${ }^{25}$ Katia Maria Abud. O sangue intimorato e as nobilíssimas tradições - a construção de um símbolo paulista: o bandeirante. Tese de Doutorado em História Social. São Paulo: FFLCH/USP (Departamento de História), 1985, p.185-186.
} 
Santos Dumont, horrorizado com o uso de sua criação para matar pessoas, teve sua morte retratada na minissérie.

Nas trincheiras, os soldados lutaram não só por São Paulo, mas também pela própria sobrevivência. O entusiasmo inicial foi sendo com o tempo substituído pelo abatimento, desânimo, a dor da saudade e de ver amigos mortos. Alguns percebem a inevitável derrota paulista:

"O entusiasmo dos primeiros meses arrefece. Uns poucos querem ainda resistir e não aceitar o armistício que lhes era oferecido. Gesto de desespero. A elite paulista vencida apressava-se em rever suas posições. Nos campos de batalhas ficaram os mortos. Na memória dos homens que participaram da revolução uma história que fala mais de seus sonhos e suas paixões do que sobre a realidade que os gerou." 26

$\mathrm{Na}$ memória do telespectador possivelmente ficou a lembrança de sonhos e paixões, ideais revolucionários contra a ditadura e a favor da Constituição. A realidade que gerou tudo isso não foi explorada totalmente na minissérie. As contradições do período são comentadas em diversos diálogos, porém sem aprofundamento, nos limites da ficção.

Anualmente, no mês de julho, realizam-se as comemorações da Revolução de 32: há desfile militar com roupas de época, faixas comemorativas, desfile de veteranos. Nos anos de 2004 e 2005, acompanhamos o evento, encerrado com uma apresentação do grupo musica Trovadores Urbanos, que cantaram músicas de compositores paulistas.

${ }^{26}$ Emília Viotti da Costa. 1932: imagens contraditórias. São Paulo: Edições Arquivo do Estado de São Paulo, 1982, p.12. 


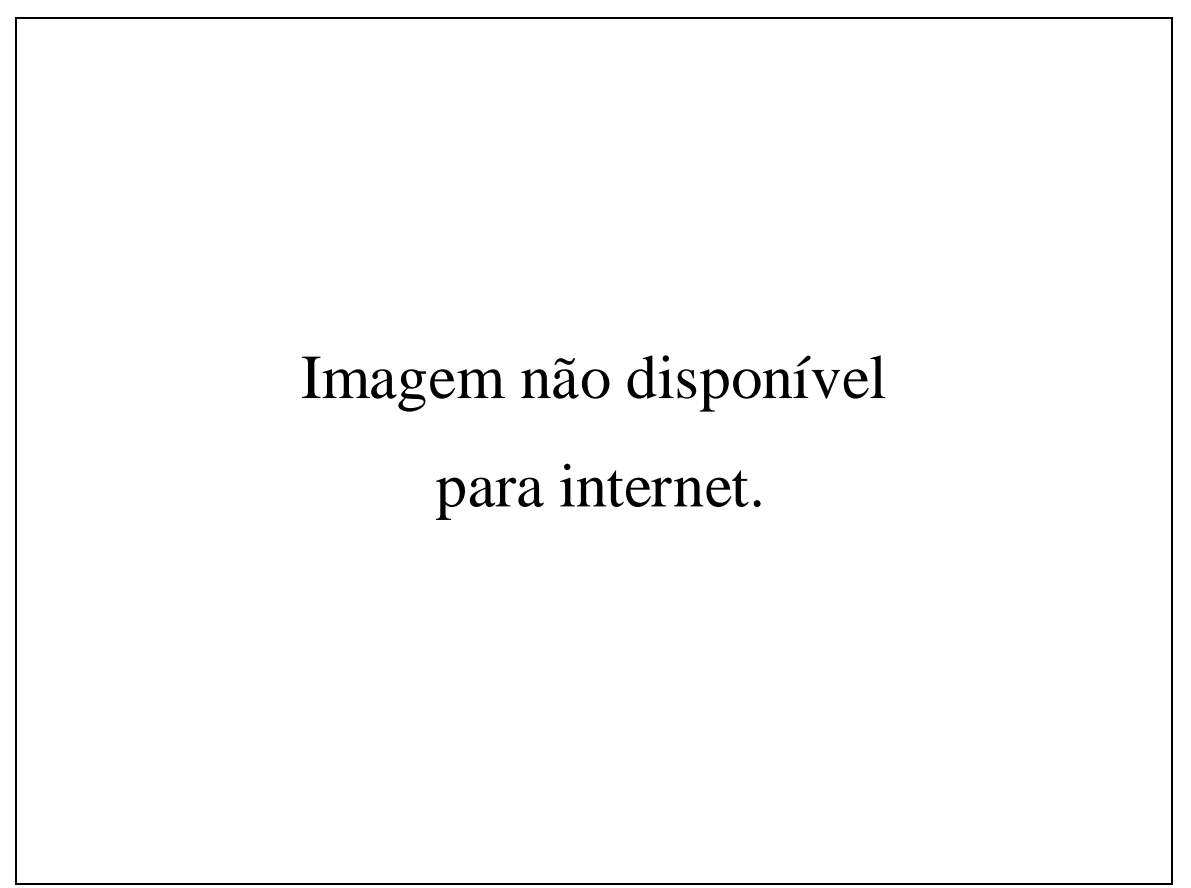

Cenas do Desfile de 9 de julho .Comemoração do aniversário da revolução, em 2005.

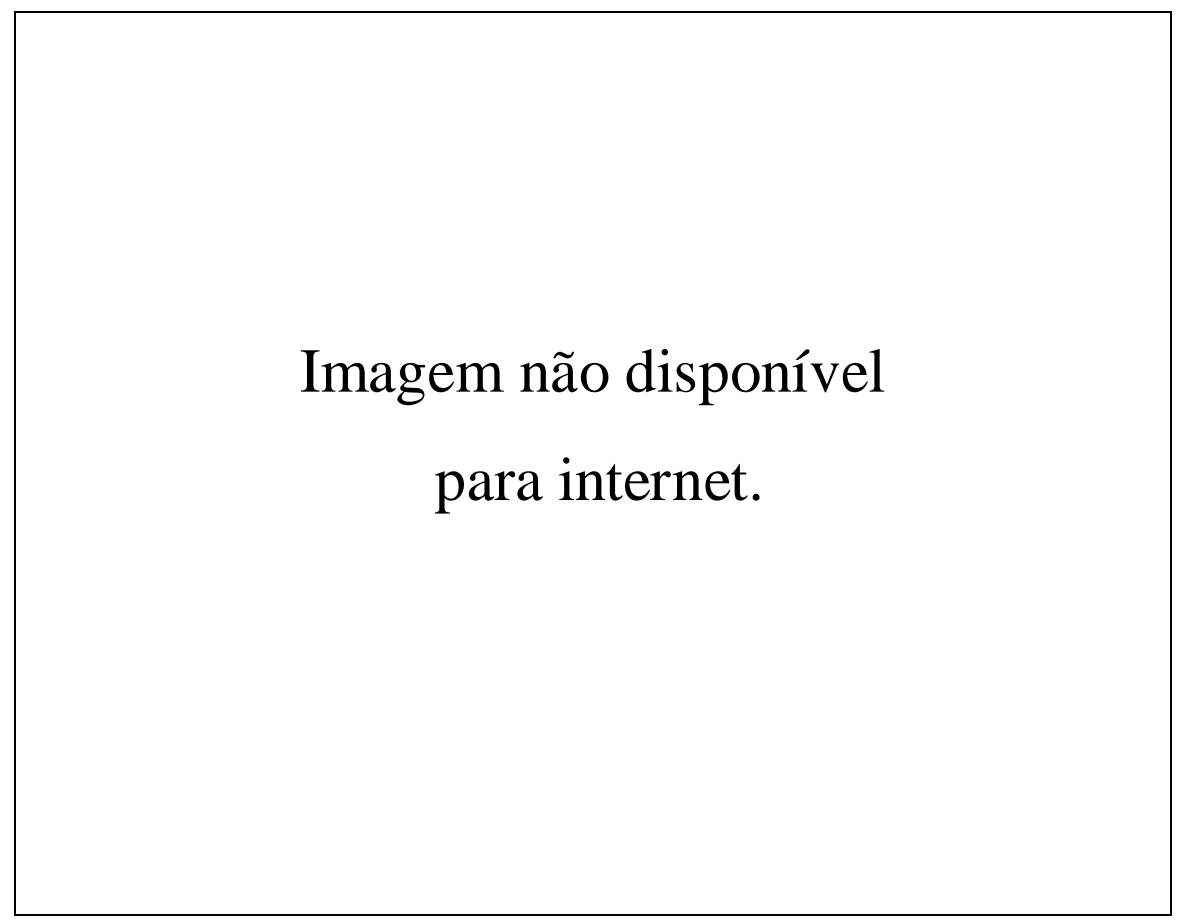

Cenas do desfile: preservação da memória e resgate de valores do paulista. 


\section{Imagem não disponível para internet.}

Não identificamos como objetivo dos autores promover uma discussão ideológica através da ficção, porém identificamos discursos dissonantes entre as personagens, o que nos indica que foi usada uma bibliografia variada. Concluímos assim, que não há preocupação com coerência ideológica, mas sim em retratar o máximo possível das informações colhidas, respeitando cronologia e fatos.

\section{Ator, personagem e preparativos da revolução}

Para esta pesquisa tivemos a oportunidade de entrevistar um dos atores de $\mathrm{Um}$ Só Coração, Renato Scarpin, que interpretou a personagem Joaquim. Esta personagem era um imigrante português que trabalhava e vivia com o tio em seu armazém.

Dentro dos elementos folhetinescos, a personagem viveu um triângulo amoroso. Joaquim era apaixonado por Ana Schimidt, uma mulher avançada para a época. Ela era assediada por Rodolfo, um dos vilões da trama, e Joaquim era assediado por sua prima Elvira.

Também dentro do contexto do folhetim, Joaquim tinha as características do herói de bom caráter, trabalhador e de princípios morais rígidos. Por essa última característica, sofria para aceitar Ana e conquistá-la. Ele começa a história pobre e vai 
prosperando, chegando a ter uma confeitaria com Ana, então sua esposa. A participação da personagem se encerrou na Revolução Constitucionalista de 1932. Como imigrante acolhido por São Paulo, sentiu-se no dever de lutar. Durante a revolução, entretanto, morre heroicamente em batalha ao tentar salvar um companheiro.

A personagem retratou uma das muitas nacionalidades de imigrantes da cidade, o seu percurso para crescer financeiramente através do comércio e a participação de imigrantes na luta em 1932.

Através desta entrevista obtivemos informações sobre as etapas de preparação da produção e como se dá a atuação de técnicos e preparação nas cenas de batalha.

Sobre as gravações das cenas de 32 explicou:

"Para as cenas da guerra de 1932, o que a gente tinha lá eram alguns meninos que faziam o dublê. Tinham uns meninos que eram de uma turma de dublês que faziam todas as cenas de explosões, que o cara saía voando, caía e se arrebentava. Esses indicavam para os atores o manejo de arma, manejo de espingarda, de revólver, de granada. Essas orientações nós tivemos lá.

As cenas da guerra foram gravadas, todas, em uma fazenda em Minas Gerais, perto de Juiz de Fora. Acho que a Globo já usou aquela locação para outros trabalhos. Ali tinha um túnel perto de uma linha de trem, que continua a ser o túnel da Mantiqueira, que aquele grupo de soldados da revolução estava lá para defender. Difícil, por exemplo, foi, na cena da morte do Joaquim, todos os efeitos especiais, de tiros. O Joaquim ia morrer com uma rajada de metralhadoras, o que dava, acho que doze tiros que ele ia levar. Enquanto a gente gravava outras cenas, esta equipe de efeitos especiais passou o dia preparando a roupa, o uniforme do Joaquim... da morte, que era cheio de explosivos... Eles passaram o dia preparando essa roupa da morte do Joaquim. Tinha explosivos pela roupa inteira, pela calça... Eu lembro que aquele era o último dia que eu ia gravar. Eu estava com uma viagem marcada para Santa Catarina e tinha que gravar antes do pôr do sol de qualquer maneira, em função da luz. Então, quase às 5 horas da tarde, lá na Serra, começou a baixar a luz rapidinho e a gente teve que gravar às pressas. Vesti aquela roupa - que era um uniforme normal, todo preparado - e passavam por dentro da calça os fios dos explosivos que, todos juntos, davam mais ou menos a grossura de um pulso... $\mathrm{E}$ esses fios todos estavam ligados em um aparelho que fazia explodir, espirrar o sangue, e tal. Só que, do aparelho até mim a gente tinha um metro e meio de fio. E a cena era o Joaquim correndo, tomando os tiros e caindo. E a gente não podia repetir - esse era o grande problema. Eles passaram um dia para preparar a roupa e iam levar mais umas quatro horas, no mínimo, para preparar uma outra roupa se fosse o caso de regravar a cena. E só poderíamos fazer no outro dia porque a luz estava caindo. Então, era um desespero; tinham quase duzentas pessoas lá e na hora de gravar esta cena foi aquele silêncio geral. O Marcelo disse: "Vamos lá, vamos lá. Atenção, gravando". E eu falei: "Marcelo, pára." Ele falou: "O que foi?" Eu falei: "Marcelo, eu sei que o sol... mais dois minutos não tem mais sol. Mas eu preciso de um segundo para me concentrar". E o Marcelo foi um anjo. Ele tremia de nervoso, mas falou: "Está bom. Silêncio". Olha, a minha responsabilidade: você sozinho, a câmera na sua frente. Duzentas pessoas em sua volta, todas te olhando, esperando você gravar a cena. Todas em 
silêncio porque o diretor mandou, o ator pediu que precisava de um segundo para se concentrar. E era um saco porque eu tinha que vir correndo, tomar os tiros e cair. Só que não era eu que acionava os explosivos. Era o técnico. Então, eu tinha que reagir depois dos explosivos, mas com outra dificuldade. Eu não podia correr porque só tinha um metro e meio de fio. Acho que tinha menos... Acho que tinha um metro. Eu me lembro que eu podia dar um passo. E no fim acabou dando tudo certo. Eu falei: "vamos lá". Dei o passo e o cara explodiu tudo. Então, teve esta preparação para todos atores que tomaram tiro, como reagir...

Talvez o Joaquim tenha feito o sucesso que fez pelo fato dele ser o espelho de boa parte da sociedade, das pessoas que chegaram aqui, e de hoje em dia mesmo. Hoje a situação do Brasil está complicada. Está complicado você arrumar emprego. Quer dizer, o desemprego está aí para milhões de pessoas. A gente vive uma recessão disfarçada. E o Joaquim é aquele cara que acredita que o trabalho rende, que você, trabalhando, conquista. Mais ou menos como este slogan do governo: "Sou brasileiro e não desisto nunca." Mas assim como o Joaquim, tem muita gente hoje que não consegue emprego e acaba montando a barraquinha de cachorro quente não sei onde. Gente com diploma... Eu, por exemplo, quando trabalhava com caminhão, conheci dois caminhoneiros que eram formados. Um era advogado e o outro era médico. $\mathrm{E}$ foram trabalhar na estrada. O brasileiro tem muito disso. Ele dá jeito, ele precisa sobreviver. O Joaquim era o arquétipo dessas pessoas que batalham, que acreditam que o trabalho honesto, com o suor do rosto, vai vir recompensado depois. E a morte dele, da forma que foi feita, dando esta conotação heróica, épica, demonstra também a questão dos princípios. Eu lembro da cena: ele vai porque vê um companheiro sendo metralhado e fala "eu vou buscar o cara". Ele era humano. Ele era bom. E as pessoas torcem pelos mocinhos. É uma pena que a grande maioria não seja como ele. Se a grande maioria fosse como ele, a gente - o Brasil - estaria infinitamente melhor. ${ }^{27}$

Imagens da morte e enterro de Joaquim.

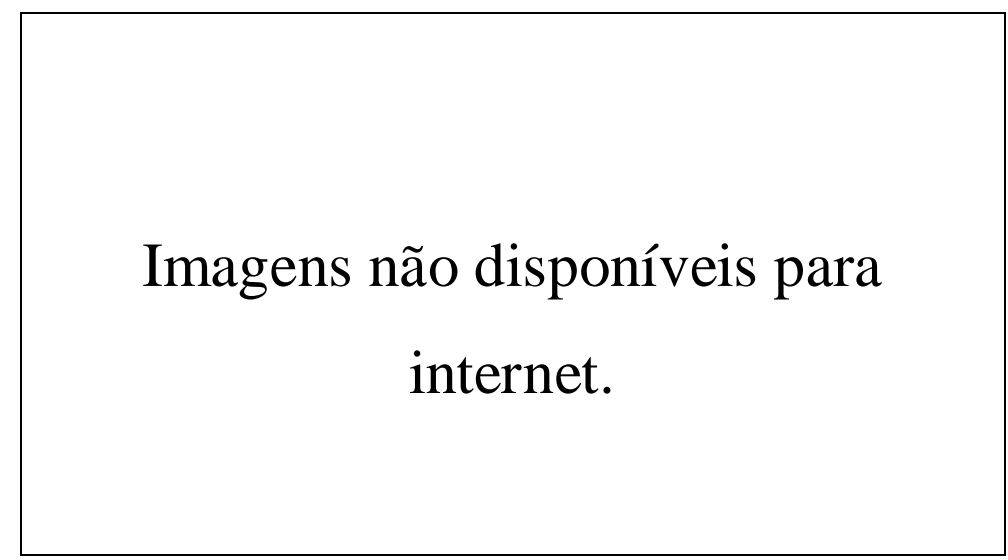

\footnotetext{
${ }^{27}$ Entrevista concedida pelo ator Renato Scarpin para esta pesquisa.
} 
Não tivemos como objetivo esgotar a minissérie Um Só Coração, já que a mesma é muito extensa e possui diversas possibilidades de estudo. Procuramos aqui indicar alguns aspectos da construção de sua ficção, porém atentamos que ela constitui uma obra mais complexa metodologicamente para análise do que foi A Muralha, seja pela sua extensão de horas em DVD, longo período narrado (trinta e dois anos), ou pela quantidade de assuntos e personagens nela retratados.

\section{OUTROS TEMAS}

Como em A Muralha, selecionamos temas que foram retratados na minissérie. Devido à falta de tempo e a impossibilidade de acesso às muitas fontes utilizadas em Um Só Coração, elencamos alguns deles para que sirvam de referência para outros trabalhos. Apontamos separadamente que só o discurso da narradora Maria Laura, em sua totalidade, poderia constituir também um tema de estudo da minissérie.

\section{POLÍTICA:}

Getúlio Vargas - Revolução de 30, Revolução de 32 e Estado Novo

Anarquismo

Comunismo

II Guerra Mundial

República do café-com-leite

Coluna Prestes

Partidos políticos

Integralismo

Movimentos nazi-fascistas na Europa

\section{ECONOMIA:}

Algodão

Crise do café

Industrialização

Comércio

Transportes

Urbanização 
CULTURA:

Música

Moda

Grupo Diários Associados

Modernismo e modernistas

Aviação

Cinema

Teatro

Pintura

Crítica literária

Artes Plásticas

Arquitetura

SOCIEDADE:

Moralidade

Condição feminina

Prostituição

Diferenças entre classes sociais

Saúde

Imigração

Migração

Famílias tradicionais paulistas 


\section{CAPÍTULO V - OS PRODUTORES}

Este capítulo tem o objetivo de apresentar alguns dos produtores de qualquer teledramaturgia, pois consideramos esta categoria de produto cultural como resultante de uma ação coletiva ${ }^{1}$, que envolve desde a empresa em que o produto foi desenvolvido, o autor/autores de roteiro, o diretor artístico, os diversos diretores, os atores até os consultores especializados.

A maior ênfase para os elementos de autoria, atuação e pesquisa histórica foi decorrente da proposta de fazer uma pesquisa tendo como um dos objetivos a compreensão do tratamento dado em algumas obras de teledramaturgia a temas históricos.

Neste capítulo apresentamos, além de dados obtidos na bibliografia, citações de entrevistas com alguns dos profissionais envolvidos, recolhidas em veículos da mídia, impressa e falada, e depoimentos colhidos na pesquisa.

Estamos deixando de lado, por absoluta impossibilidade técnica de pesquisa, outros tantos colaboradores: cenografista, iluminador, figurinista, câmeras, maquiador, diretor musical, produtor, instrutor de dramaturgia, editor, responsáveis por efeitos visuais, sonoros e abertura, entre tantos profissionais que atuam nos bastidores da teledramaturgia.

É consensual que na sociedade contemporânea há vários produtos culturais que são resultantes da atuação de diversos atores sociais, especialmente os classificados como produção cultural para sociedade de massa, de consumo imediato ou rápido, em que um dos alvos é o resultado financeiro obtido, quer como retorno dos investimentos realizados para a própria produção, quer como obtenção de lucros, para serem repassados a outras áreas na cadeia da produção, amortizando investimentos em equipamentos e em formação, treinamento e contratação de pessoal técnico especializado, quer como processo de capitalização da empresa.

A produção cultural televisiva é sempre o resultado de uma atuação coletiva, que tem como ponto de partida a empresa em que é produzida. Aos olhos dos telespectadores, a empresa é a responsável e a produtora, pois é a emissora. Na prática, há diferença entre empresa produtora e emissora, pois esta segunda categoria pode

\footnotetext{
${ }^{1}$ Nosso entendimento de coletivo se dá em função do envolvimento de diversos profissionais para realizar uma novela, ou minissérie. Porém, vemos que esse tipo de produção cultural se realiza dentro de um
} 
adquirir produção no mercado sem ter que se envolver diretamente na produção, o que ainda hoje não é claramente captado pela audiência no país.

No Brasil, a empresa de comunicação que produz e emite teledramaturgia em grande quantidade, mantendo até quatro produções de tipos diversos, em horários diferentes, é a Rede Globo.

Em nossos dias já enfrenta a concorrência de outras emissoras, que também têm como objetivo alcançar maior audiência e melhor retorno financeiro de seus investimentos.

\section{AS ORGANIZAÇÕES GLOBO}

A Rede Globo de Televisão é uma das inúmeras empresas que fazem parte das chamadas Organizações Globo. Incluem-se entre as empresas das Organizações Globo, além do setor de mídia, “...fábricas de móveis e de microeletrônica até fazendas de gado na Amazônia. (...).,"2

De acordo com o portal www.globo.com ${ }^{3}$, podemos encontrar diversas empresas relacionadas aos setores de mídia e comunicação das Organizações Globo. Em relação à mídia impressa, encontramos dois jornais de grande circulação, $O$ Globo e Diário de São Paulo, e a Editora Globo ${ }^{4}$, que é responsável pela publicação de inúmeras revistas como o semanário Época, a revista Quem (especializada em celebridades), as femininas Marie Claire e Criativa, a científica Galileu, além de Globo Rural, Pequenas Empresas \& Grandes Negócios, Crescer, Autoesporte, Casa \& Jardim e vários títulos infantis.

Dentro do Sistema Globo de Rádio estão as rádios Globo, CBN e 98 FM. No segmento musical, há a gravadora Som Livre, que vende no mercado as trilhas sonoras dos programas da emissora.

esquema de produção industrial, gerenciado pela empresa produtora, que orienta as ações dos diversos profissionais envolvidos.

${ }^{2}$ João Olavo de Donato. O capital estrangeiro e as empresas de teledifusão brasileiras: o caso da Rede Globo e PGQ - Padrão Globo de Qualidade. Tese de Doutorado em História Econômica. São Paulo: FFLCH/USP (Departamento de História), 2002, p. 144.

${ }^{3}$ Ver www.globo.com

4 “Em 1986, a então Rio Gráfica Editora, fundada em 1957, incorporou a Editora Globo, de Porto Alegre. A partir daí além das revistas, passou a editar livros e fascículos e assumiu o nome de Editora Globo. Com a reorganização pela qual passou em 1989, a Editora Globo evoluiu para se tornar a segunda maior do país", cf. Quem somos, in http://editoraglobo.globo.com/ 
Atualmente, há a Globo Filmes, que é o segmento responsável por investimentos no cinema. Os profissionais da emissora são aproveitados para fazer filmes, que atraem público pela participação de atores e diretores conhecidos.

A Globo também expande sua programação na TV por assinatura, através das empresas Globosat, Net e Sky, que transmitem os canais Globo News, GNT, e o educativo Futura, entre outros. A Net também atua na internet com o provedor Net Virtua.

O portal www.globo.com hospeda vários sites das empresas das Organizações Globo. Apresenta conteúdo diário de informação sobre política, economia, cultura, esportes e personalidades, outros sites institucionais, como o da Fundação Bienal de São Paulo, e de projetos sociais.

Dentro das Organizações Globo há também instituições e projetos direcionados ao interesse público e social. É o caso da Fundação Roberto Marinho, que atualmente colabora, entre outros, com o Museu da Língua Portuguesa, em São Paulo.

Esse enorme grupo empresarial teve início com o jornal $O$ Globo, herdado do pai pelo jornalista Roberto Marinho, aos 20 anos, em 1925. O jornal tinha acabado de ser fundado quando o pai do jornalista morreu. Marinho esperou seis anos para assumilo. Apesar de ser o herdeiro, indicou um diretor, pois não se sentia em condições de se responsabilizar pela redação no momento. Durante anos ele se dedicou a consolidar o jornal e, em 1944, fundou a Rádio Globo. O próximo passo era a televisão e, a partir dela, o surgimento de inúmeras possibilidades de expansão.

O que poderia ser apenas uma empresa jornalística familiar, como tantas outras no país, foi se transformando em uma grande empresa de comunicação, administrada por profissionais, embora membros da família Marinho ainda tenham algumas funções administrativas.

A transformação da empresa jornalística familiar em uma empresa de comunicação teve como ponto de partida a obtenção de direito de uso de um canal de televisão.

\section{A EMISSORA DE TELEVISÃO}

A emissora de televisão foi inaugurada em 26 de abril de 1965 no Rio de Janeiro, no período da ditadura militar, mas seu projeto era bem antigo. Conforme 
consta em depoimento de Roberto Marinho para Olavo Donato ${ }^{5}$ e, com mais informações, em relato de Pedro Bial:

"TV Globo. Pouca gente sabe, mas uma das histórias mais espetaculares da televisão mundial já tinha começado naqueles idos de 1950. Em 9 de janeiro de 1951, a Rádio Globo encaminhara oficialmente ao governo Dutra o pedido de concessão de um canal de TV. (...).No dia 13 de março de 1951, Getúlio já empossado, o requerimento foi aprovado pelo governo. Dois anos depois, em janeiro de 1953, o presidente Vargas voltou atrás e revogou a concessão da TV Globo. Juscelino Kubitschek, em 1957, devolveria o direito de Roberto Marinho fazer a sua televisão. A segunda concessão para um canal em Brasília, foi outorgada por João Goulart. Todos os outros canais, que viriam a formar a Rede Globo, foram comprados mesmo, o Estado não deu mais nada. (...).",6

Em São Paulo, começou suas atividades em 24 de março de 1966.

Em seus anos iniciais teve a colaboração financeira e técnica do grupo norteamericano Time-Life. Segundo Sérgio Mattos ${ }^{7}$, o contrato permitia ao grupo estrangeiro participação nos lucros, o que foi estabelecido de forma legal, porém contrariando o artigo 160 da Constituição de 1964, que não permitia às companhias estrangeiras o direito de propriedade sobre meios de comunicação. ${ }^{8}$

João Olavo de Donato explica como se deu a negociação, apesar dos impedimentos legais:

“(...). Mas o acordo de cooperação técnica era interessante para ambas as partes, os advogados do Time-Life - José Nabuco e Sérgio Ckermont, e o da TV Globo - Luís Gonzaga do Nascimento e Silva, conseguiram conceber um artifício jurídico pelo qual o Time-Life tornava-se proprietário do prédio onde se instalara $O$ Globo e como forma de pagamento de aluguel receberia 3,5\% do faturamento e $49 \%$ do lucro da emissora. O contrato de assistência técnica foi assinado em 24 de julho de 1962 e o de arrendamento da sede da emissora, em 15 de janeiro de 1965. (...)."

\footnotetext{
${ }^{5}$ João Olavo de Donato. op.cit., p.145-146.

${ }^{6}$ Pedro Bial. Roberto Marinho. Rio de Janeiro: Jorge Zahar Ed., 2004, p.178-179.

${ }^{7}$ Sérgio Mattos. A televisão no Brasil: 50 anos de história (1950-2000). Salvador: Editora PAS; Edições Ianamá, 2000, p. 109-111.

${ }^{8}$ Em 2002, Daniel Castro e Laura Mattos publicaram matéria na Folha de S. Paulo sobre a aprovação no Congresso de uma emenda constitucional que liberava a entrada de investimentos estrangeiros na mídia. As dificuldades para que isso acontecesse eram: a regulamentação para detalhar as regras para os acordos com sócios estrangeiros; a situação econômica do país na época; a estrutura familiar e problemas judiciais de algumas TVs. O primeiro passo estava sendo dado ao liberar a participação de pessoas jurídicas na mídia. Até então as empresas de comunicação só podiam estar registradas em nome de pessoas físicas. A Globo anunciou em 19 de junho de 2002 a sua transformação em empresa de capital aberto. Daniel Castro e Laura Mattos. Sociedade anônima. Folha de S. Paulo, 21/06/2002, c. Ilustrada, p. E1.

${ }^{9}$ João Olavo de Donato. op.cit., p. 147.
} 
A Time-Life se desligou da Globo em $1969 .{ }^{10}$

A programação foi, a princípio, direcionada às camadas sócio-econômicas de menor poder aquisitivo, assegurando à emissora larga audiência, no final dos anos sessenta. Nos anos setenta, alcançou grande desenvolvimento, apostando em estratégias comerciais tais como a criação um departamento de pesquisa e análise, a adequação de programas a diferentes gostos e padrões culturais, e o planejamento do uso de publicidade em seus programas. ${ }^{11}$ Outro elemento de transformação foi a nacionalização de sua programação ${ }^{12}$ e o início do chamado "Padrão Globo de Qualidade". A emissora preocupou-se com a melhora na qualidade técnica e no conteúdo dos programas.

$\mathrm{Na}$ mesma época, a emissora entrou no mercado internacional, ganhando prêmios, como o prêmio "Salute", em 1979, oferecido pela Academia Nacional de Artes e Ciências da Televisão, dos Estados Unidos, e exportando produções. No mesmo ano, já exportava programas para mais de noventa países, sendo a novela O Bem Amado (1973), a primeira produção televisiva a obter expressiva receptividade no exterior. ${ }^{13}$

Sérgio Mattos afirma que, na época do governo militar, a emissora foi favorecida:

\begin{abstract}
"Sem dúvidas, o governo foi a mais importante força motriz por trás do desenvolvimento da indústria televisiva brasileira, especialmente da TV Globo (criada depois do golpe de 64). Ao criar facilidades nas telecomunicações, tais como as redes de microondas, o cabo coaxial, os satélites e a televisão a cor, o regime militar brasileiro contribuiu para o desenvolvimento técnico da televisão, utilizando-a para promover os ideais do regime. Os governos do período 1964-1985, com suas políticas protecionistas, afetaram o desenvolvimento da indústria publicitária no país e, em conseqüência, também da televisão."14
\end{abstract}

Na história recente do Brasil, a Globo sempre esteve presente, mesmo quando omitiu, em suas narrativas jornalísticas, alguns fatos, permitindo a clara percepção de suas posições, contrárias ou favoráveis a determinado acontecimento, e a identificação do grupo político ao qual se alia. Exemplos de tal comportamento foram: a opção por não mencionar em seus telejornais as passeatas em Curitiba, Vitória, Salvador e Campinas pelo movimento das "Diretas Já" e, ao mesmo tempo, por mostrar a

\footnotetext{
${ }^{10}$ Idem., p. 148.

${ }^{11}$ Sérgio Mattos. op. cit., p.109-111.

${ }^{12}$ Nos anos cinquienta e sessenta, a programação da televisão apresentava muitos programas de origem estrangeira, os chamados "enlatados".

${ }^{13}$ Sérgio Mattos. op. cit., p.123 a 125.

14 Idem., p.132-133.
} 
manifestação em São Paulo, em 25 de janeiro de 1984, mesclando o pedido por eleições diretas e o aniversário da cidade; e o apoio da emissora à candidatura de Fernando Collor de Mello, e, depois, ao seu impedimento. ${ }^{15}$

$\mathrm{Na}$ área da teledramaturgia, a emissora Globo absorveu reconhecidos nomes do teatro e do cinema, autores, diretores e atores, além de todos os outros profissionais especializados em produção audiovisual. Esses profissionais, muitas vezes vigiados pelo regime, pois eram considerados suspeitos de serem portadores de idéias subversivas, e/ou membros de partidos políticos ilegais, acabaram trabalhando em uma emissora que servia de porta-voz ao regime militar.

Contudo, mesmo como a emissora preferida do regime, como todos os veículos de comunicação, também esteve sob vigilância e sofreu com a censura. Como era prática obrigatória naquele tempo, todas as produções eram submetidas à censura prévia e muitas cenas de novelas foram cortadas. O caso mais drástico enfrentado pela emissora foi o da novela Roque Santeiro, de Dias Gomes, que teve sua primeira versão censurada em $1975{ }^{16}$

Apesar da censura, tal período tem sido considerado como o mais fecundo da teledramaturgia brasileira. Segundo os autores especializados, o chamado "modelo mexicano" na produção da teledramaturgia foi abandonado e firmou-se uma produção com características nacionais, com originalidade de textos e maior realismo.

A partir de 2000, a emissora lançou alguns produtos no mercado com intuito de apresentar sua história e demonstrar a importância que considera ter para a cultura nacional. Entre eles, destacamos o Dicionário da TV Globo-vol.1: programas de dramaturgia e entretenimento, que contém os dados e informações sobre a produção da emissora desde o início de suas atividades.

Na apresentação da publicação, o diretor da Central Globo de Comunicação, Luís Erlanger, faz a seguinte colocação:

"Num país de dimensões territoriais como as nossas e de cultura de massa diversificada e fértil, que mistura tradição e modernidade, a televisão desempenha uma função marcante na consolidação da identidade nacional. Por

15 Leandro Narloch . A voz do Brasil. Super Interessante, São Paulo: Abril, edição 214, jun./2005, p.55.

${ }^{16}$ Dicionário da TV Globo, v.1: programas de dramaturgia \& entretenimento (Projeto Memória das Organizações Globo. Rio de Janeiro: Jorge Zahar Ed., 2003, p.142. Sobre a censura à primeira versão de Roque Santeiro, com documentos, capítulos censurados e depoimentos de atores ver: Maria Fernanda Almeida. A novela proibida. Revista Contigo, São Paulo: Abril, 01/09/2005, edição 1563, p. 94-101. 
suas características, a Rede Globo assume um papel de importância indiscutível nesse processo..."17

Em sua versão do passado, a emissora, que afirma ter sido cerceada pelo regime militar no jornalismo, declara que a dramaturgia serviu de espaço para a crítica:

"Durante o regime militar, em que o jornalismo da Rede Globo - em alguns casos, mais do que em outros veículos de comunicação - era cerceado pela censura, coube à dramaturgia desempenhar a tarefa de retratar e criticar a realidade política e social do país. Com toda essa força de comunicação - e acima de tudo por sua aceitação pelos brasileiros - , a emissora é hoje uma das mais importantes fontes de difusão cultural dentro e fora do Brasil.(...)."

A idéia de que a Globo (ou, em especial, a sua produção de novelas) seja fator de integração nacional, encontra respaldo em alguns estudos sobre a televisão.

Dominique Wolton, por exemplo, faz as seguintes colocações:

“(...). De fato a Globo coloca-se como uma indústria, um instrumento de modernização e integração e um fator de identidade nacional. Ela é um instrumento de cultura de massa numa sociedade hierarquizada. Se o seu objetivo não é modificar as estruturas sociais, é, pelo menos, saber apreendê-las e acompanhá-las. Aí encontramos de imediato o papel de laço social da televisão. (....)."19

“(...). E não resta dúvida de que o controle político da televisão brasileira durante a ditadura militar foi aceito, mas não nos programas, dos quais as telenovelas gozavam de uma maior liberdade. As telenovelas são uma das alianças mais interessantes do mundo entre uma capacidade criadora evidente e os interesses materiais. O mais surpreendente é o caráter realmente popular desses folhetins. Sem dúvida, segundo os horários, os produtos são muito diferentes, mas resta um ponto em comum: todas as classes sociais assistem às novelas. Temos aí, sem dúvida, uma das verificações experimentais mais naturais da teoria da televisão como laço social! Mesmo que já tenha dito tudo sobre o fenômeno social do folhetim brasileiro, é preciso sublinhar ainda a sua importância como espelho da sociedade, ao mesmo tempo que fator estruturador da identidade brasileira. Trata-se quase de um caso de escola, ilustrando o papel antropológico fundamental da televisão! E a coexistência de diversos gêneros de telenovelas para diferentes públicos, assim como sua duração, ilustram, igualmente, a inteligência dos públicos. Estes não entregariam a sua confiança, há tanto tempo, a esses programas, se eles não tivessem incorporado uma parte da inteligência popular! Isso já foi visto durante a ditadura militar, onde a liberdade crítica manifestou-se nesses folhetins quando essa mesma liberdade estava amordaçada na informação. De fato, o folhetim brasileiro está de tal

\footnotetext{
${ }^{17}$ Luis Erlanger. Apresentação. Dicionário da TV Globo, op.cit., p.ix.

${ }^{18}$ Idem.

${ }^{19}$ Dominique Wolton. Elogio do grande público; uma teoria crítica da televisão. São Paulo: Ática, 1996, p.159-160.
} 
forma inscrito na identidade e no sonho nacional, que, segundo as épocas, ele é reflexo de todas as histórias. ${ }^{, 20}$

Dominique Wolton é um entusiasta da televisão brasileira, pois a vê como exemplo para sua tese de televisão geralista, que apresenta programas de temas variados e assistidos por todos os níveis sociais, pois o autor acredita na inteligência do público. Uma das funções da televisão geralista é promover o laço social, pois para ele o mais importante não é o que se vê, mas o que se fala sobre o que se vê: Para ele,“(...).A televisão é um objeto de conversação. (...)."21

Esther Hamburger reconhece o poder da novela, porém como algo que falseia um senso de comunidade nacional:

\begin{abstract}
"O critério de verossimilhança do universo fíccional das novelas é construído através da apropriação recorrente de elementos da linguagem jornalística e documental para aludir a eventos da conjuntura, elementos da cultura e da história do Brasil. Ao misturar convenções da ficção com convenções da notícia, as novelas foram fazendo referências a repertórios nacionais e, inadvertidamente, se estabeleceram como repertório compartilhado, espaço virtual promíscuo, cujo verossimilhança depende da apropriação e elaboração de elementos do cotidiano - uma convenção inaugurada nos folhetins do século XIX. Esse repertório compartilhado é fruto também da agenda ideológica dos profissionais que fizeram o gênero. Em sua busca pelo imediato, as novelas se oferecem como conexão entre o domínio privado da vida doméstica e o domínio público da política, forjando um peculiar senso de comunidade nacional.,22
\end{abstract}

A visão de Esther Hamburguer se contrapõe à importância que a própria emissora atribui ao seu papel como fator de integração nacional. Este papel é visto pela autora como algo forjado, ou seja, há uma impressão de comunidade nacional, mas esta não existe.

A compreensão do papel da emissora Globo, particularmente da produção de teledramaturgia, na questão da identidade nacional é de fundamental importância. Não podemos negar tal papel, mas não podemos aceitar o discurso da emissora sem uma reflexão sobre o tipo de cultura que ela produz e a forma como alcança a população.

Percebemos no discurso oficial da emissora que ela considera ter um papel importante para a cultura nacional, porém, em nosso entender, não pode ser vista como a principal, ou, de forma exagerada, como a única criadora de cultura no Brasil. Sua

\footnotetext{
${ }^{20}$ Idem., p.164.

${ }^{21}$ Idem, p.16.

${ }^{22}$ Esther Hamburger. O Brasil antenado: A sociedade da novela. Rio de Janeiro: Jorge Zahar Ed., 2005, p. 118.
} 
importância está mais no alcance de sua produção, visto que é a emissora líder de audiência, e por investir de modo sistemático para se manter na posição.

Quanto à qualidade ou ao conteúdo de seus produtos, vemos neles grande variação: há produtos destinados a todas as faixas de público consumidor, desde o que se satisfaz com produção cultural popular quase que caricatural e próxima do humor circense, até produtos experimentais, com a introdução de técnicas sofisticadas de tipo cinematográfico ou teatral, produtos de vanguarda, destinados a público mais sofisticado e restrito. Em quase todos os produtos, há o cuidado com a linguagem televisiva e a preocupação em acompanhar os desenvolvimentos tecnológicos. Por outro lado, a preocupação com a audiência, que deve ser sempre mantida ou ampliada em relação aos produtos anteriores, acaba sendo um elemento de limitação de inovações, pois deve atender a critérios morais e/ou preconceitos sociais, que podem ser arcaicos ou conservadores. Como exemplo disso, citamos a polêmica causada com os depoimentos no final de Páginas da Vida, que passaram a ter um controle e edição mais rigorosos, após criarem polêmicas com seus conteúdos espontâneos. É também o que leva a emissora a organizar um manual com princípios e normas para novelas e telejornais, visando manter a qualidade de sua programação. ${ }^{23}$

A introdução de novos comportamentos, sugeridos em sua produção, exceto os destinados a consumo de massa, atendendo às necessidades do mercado de propaganda, tende a ser concretizada de forma muito lenta.

No momento atual no país, cabe a outras emissoras exercer o papel de agente de inovação, quer ao testar novas formas de produção, novos conteúdos, novas formas de apresentação de conteúdo, novas relações com o mercado produtor e com o mercado consumidor. São elas as emissoras educativas, MTV e os canais por assinatura, destinados a consumidores previamente identificados, acompanhando a fragmentação das identidades sociais.

Alguns dos canais por assinatura divulgam novos produtos de teledramaturgia nacional, resultados de atuação de produção televisiva independente ou parcialmente

\footnotetext{
${ }^{23}$ Daniel Castro. Globo terá manual para novelas e jornais. Folha de S. Paulo, 25/08/2006, caderno Ilustrada, p.E10.
} 
financiada, possibilitando a formação de um mercado independente da produção das emissoras de sinal aberto. ${ }^{24}$

\section{AUTOR/AUTORES}

É reconhecido em nossos dias que, ao realizar uma obra de arte, qualquer que seja a forma de expressão artística ou literária, o artista age intuitivamente, nem sempre tendo plena consciência dos pontos em comum que elas podem apresentar. $\mathrm{O}$ artista retrata elementos de seu próprio universo e de suas experiências e vivências, reelaboradas e redimensionadas. A proposta analítica que vê a obra de arte como um mero reflexo da sociedade, tão presente no século passado, em nossos dias não tem a adesão total dos teóricos, que sempre tentam observar o universo pessoal e intransferível do artista.

E, por extensão, a mesma perspectiva deve ser aplicada ao autor/autores de teledramaturgia. As descrições que faremos deles têm a finalidade de servir de ponto de apoio para as conclusões da pesquisa que ora apresentamos.

A autoria de uma produção televisiva é coletiva, mas as etapas de produção são assumidas por diversos indivíduos.

Neste item vamos apresentar os autores dos roteiros e seus colaboradores. Embora a própria divulgação da emissora atribua a determinados indivíduos a autoria do roteiro, sempre aparecem os colaboradores. A novela de Y é na verdade a novela de Y, e J e até mesmo W. ${ }^{25}$

O fato da produção da teledramaturgia ser complexa, exigindo grande número de personagens, em trama romanesca, realizada em tempo acelerado, envolve inúmeros aspectos de estruturação que na prática cotidiana obrigam o exercício da autoria a ser compartilhado. O compartilhamento da atividade autoral favorece a emissora também, porque possibilita a formação e o treinamento em campo de outros autores, que, por sua vez, ao se tornarem os autores principais de novela, permitirão a outros seguirem a mesma trajetória, garantindo a continuidade de um padrão de trabalho, que foi desenvolvido através dos anos e de muitas produções.

\footnotetext{
${ }^{24}$ São exemplos dessas produções as séries Mandrake e Filhos do Carnaval, produzidas pelo canal HBO e Avassaladoras, que antes de ser exibida na TV aberta pela Record, começou a ser exibida pelo canal Fox.

${ }^{25}$ Sobre a questão de autoria em telenovela ver Lisandro Nogueira. O autor na televisão. Goiânia: Ed. da UFG; São Paulo: EDUSP, 2002.
} 
A trajetória de Maria Adelaide Amaral, autora das minisséries de caráter histórico que escolhemos para analisar, é, de certo modo, exemplar do processo de formação de autor de teledramaturgia no país.

A autora citada começou sua carreira na televisão como colaboradora de Cassiano Gabus Mendes, em 1990, na novela Meu Bem, Meu Mal. Desde então, não parou de produzir para a TV. Antes de Meu Bem, Meu Mal, teve uma experiência de estepe (sic) de Lauro César Muniz, em 1979, ajudando-o com a novela Os Gigantes. ${ }^{26}$ Depois, atuou como colaboradora de Sílvio de Abreu nas novelas Deus nos Acuda (1992) e A Próxima Vítima (1995), e de Marcílio Moraes em Sonho Meu (1994), sempre na Rede Globo. A primeira telenovela em que foi responsável pela autoria foi o remake de Anjo Mau, em 1997. Trabalhou também como autora em seis episódios do seriado Mulher e, desde 2000, dedica-se às minisséries históricas, consagrando-se como autora no formato e no horário. Além de sua obra para televisão, possui carreira autônoma como autora de peças teatrais e literárias. Na sua obra para o teatro estão peças como $A$ Resistência; Bodas de Papel; Chiquinha Gonzaga, ó Abre Alas; De Braços Abertos; Querida Mamãe; Tarsila, Mademoiselle Chanel, entre outras e adaptações como Electra, Uma Relação tão delicada e O Evangelho Segundo Jesus Cristo. Na literatura, escreveu Luísa, Quase uma História de Amor, Aos Meus Amigos e O Bruxo.

Em sua ficção televisiva encontramos alguns elementos: o gosto pela história, pela literatura e pela cidade de São Paulo. Esta última característica a relaciona com os trabalhos de Sílvio de Abreu, um autor que reconhecidamente explora a ambiência paulistana em suas obras. Ela, na sua versão de Anjo Mau, ambientou a novela em São Paulo, mostrando ações de pessoas na cidade, como podemos ver em alguns exemplos ligados a fatos do universo cultural: um espaço privilegiado foi a FAAP (Faculdades Armando Álvares Penteado), na qual estudava um grupo de personagens; outro, a Pinacoteca do Estado, citada em um capítulo no qual a personagem Nice doava um quadro para a instituição, recebido por Emanoel Araújo, seu diretor no momento, ou a citação de cursos da Fundação Maria Luíza e Oscar Americano.

\footnotetext{
${ }^{26} \mathrm{Na}$ função de estepe ela deveria assumir a novela caso o autor necessitasse de substituição, em caso de doença, que foi o que aconteceu. In: Tuna Dwek. Maria Adelaide Amaral: a emoção libertária. São Paulo: Imprensa Oficial do Estado de São Paulo: Cultura: Fundação Padre Anchieta, 2005, p.155-156.
} 
Podemos verificar que o universo cultural da cidade foi retomado em Um Só Coração, já que o objetivo da autora e de seu parceiro, Alcides Nogueira, era contar a história da cidade do ponto de vista da cultura.

O gosto pela história e pela literatura aparece em outras produções como $A$ Muralha, inspirada no romance de Dinah Silveira de Queiroz; Os Maias, baseada em obras de Eça de Queiroz, e, em A Casa das Sete Mulheres, inspirada na obra de Letícia Wierzchowski.

As obras de teledramaturgia Um Só Coração e $J K$ são textos originais, com profunda pesquisa histórica.

Segundo a autora, sua paixão pelos livros e pela História começou na infância:

“(...).Eu me refugiava nos livros de histórias. Embarcava em qualquer narrativa sobre fadas e princesas, passava a viver o que eu lia num exercício de pura evasão. Eu lia compulsivamente, adorava, sorvia e vivia emocionalmente de leitura. Mais tarde, quando fui estudar História, os castelos de Reis e Rainhas eram como castelos das minhas histórias. Acho que foi essa sensação que despertaria a minha paixão pela História, uma das mais longas e permanentes de minha vida." 27

Em sua biografia, ao falar de Um Só Coração comenta:

"Gosto muito desse tipo de minissérie de época, desse filão com muitas possibilidades, que une a história real com a ficção, personagens reais e inventados, gosto muito de fazer e acho que faço bem. É freqüente cruzar com pessoas na rua que me perguntam: 'Então, sobre o que vai tratar a sua próxima minissérie?' Ou a gente que me diz: 'Aprendi tanto sobre a Revolução de 32', ou: 'Aprendo tanto com as suas minisséries'. E constato que tenho um público que espera que as minhas minisséries lhe ensinem alguma coisa." 28

Maria Adelaide nasceu em Portugal, mas veio para o Brasil com aproximadamente doze anos. Cresceu e viveu em São Paulo.

A relação de Maria Adelaide Amaral com o trabalho de pesquisa é antiga. Antes de se dedicar à carreira de escritora, ela trabalhou como pesquisadora da Editora Abril. Entre seus trabalhos, participou da pesquisa de coleções como Arte nos Séculos e da Enciclopédia Abril, escrevendo os verbetes de teatro. Sábato Magaldi era o consultor desta última, e foi para ele que apresentou o texto de sua primeira peça, A Resistência, com argumentos da experiência de uma ameaça de demissão em massa que seu setor

\footnotetext{
${ }^{27}$ Tuna Dwek. Maria Adelaide Amaral: a emoção libertária, op. cit., p.26-27.

${ }^{28}$ Idem, p.267
} 
sofreu na Abril. ${ }^{29}$ Mesmo começando atuar como dramaturga, ainda continuou trabalhando na Abril. Quanto a sua formação, bacharelou-se em jornalismo pela Cásper Líbero, mas antes chegou a cursar por um tempo Ciências Sociais na USP.

Entre seus colaboradores mais constantes estão João Emanuel Carneiro e Vicent Villari, com os quais trabalhou em A Muralha.

João Emanuel foi roteirista de Central do Brasil e também colaborador de Maria Adelaide em Os Maias, respondendo pela parte de A Relíquia. Atualmente, é considerado um dos autores mais promissores da emissora. Escreveu recentemente Cobras \& Lagartos, novela "das sete", que melhorou os índices de audiência do horário, que estavam baixos para o padrão da emissora. Também no mesmo horário, foi autor de Da Cor do Pecado (2004), considerada um grande sucesso. É autor de vários roteiros de cinema.

Outro colaborador é Vicent Villari, que a acompanhou também em Anjo Mau, Os Maias e A Casa das Sete Mulheres. Atualmente, trabalha como colaborador de João Emanuel em Cobras \& Lagartos. Também foi colaborador em Da Cor do Pecado.

Alcides Nogueira é autor do texto de Um Só Coração com Maria Adelaide. Alcides e Maria Adelaide se conheciam de trabalhos realizados com Silvio de Abreu. Natural de Botucatu, em São Paulo, estudou na Faculdade de Direito do Largo São Francisco. Descende de família bandeirante, e seu pai lutou na Revolução de 1932, o que foi muito importante para o autor ao escrever Um Só Coração:

"Escrever Um Só Coração foi, para mim, fazer uma viagem proustiana, uma coisa complexa de um lado e fascinante de outro, porque eu tive de rever valores e ao mesmo tempo entender, não mais criticar, mas tentar aprender ou introjetar, valores que perduraram durante muito tempo na minha família. Eu ouvia e criticava. Mas tive de entender esses valores como parte da memória que eu tenho de toda uma brasilidade, não apenas minha. E muito especificamente de São Paulo. Por exemplo, durante muito tempo eu tive uma postura dura em relação à Revolução de 1932. Eu não entendi o sentimento que permeava esse movimento. Passei anos com a opinião de que havia sido um movimento reacionário e não uma revolução. Eu achava que se lutava por uma constituição retrógrada. Os valores não atendiam mais reivindicações sociais, e eu não tinha entendido que havia sido um grande movimento de massa, o único verdadeiramente homogêneo: ele reuniu desde a aristocracia até as classe operárias em torno de um ideal, a constitucionalização do país. Isso é muito sério.

\footnotetext{
${ }^{29}$ Idem, p. 69-76.
} 
Hoje eu vejo que a Revolução de 32 coloca essa questão [discussão da ordem social] de modo mais contundente do que a Revolução de 30. Além de tudo, eivada de emoção. Não é um movimento cerebral, esquematizado nos salões, nos escritórios e nos jornais. Ele extrapola os centros do Poder (sic), e se espraia pelas cidade do Interior (sic), pelo campo, tomando todo o Estado de São Paulo, há uma comoção.

Tudo isso estava explícito quando mostramos a batalha do túnel na minissérie com todos os componentes cantando e lutando sem armamento, e cheios de fervor. O lema era não só Tudo por São Paulo, era Tudo pelo Brasil. A vontade era de mudar o País (sic), que Getúlio Vargas nos desse a Constituição e que houvesse uma ordem social mais justa." ${ }^{\text {30 }}$

A visão de Alcides Nogueira do momento da Revolução de 1932 foi muito destacada durante a minissérie. Da forma como foi retratada, a Revolução foi um movimento de união de todos os paulistas, mesmo que fossem de classes sociais e universos culturais diferentes. Apesar de Um Só Coração haver retratado diversos acontecimentos políticos do período, podemos considerar que Revolução de 1932 foi o grande acontecimento político da minissérie.

Na televisão, além das minisséries, em que foi parceiro de Maria Adelaide, é coautor de De Quina Pra Lua (1986), O Amor Está no Ar (1997) e Força de Um Desejo (1999), sendo esta última junto com Gilberto Braga. Além de trabalhar como colaborador de Sílvio de Abreu, atuou na mesma função com Gilberto Braga, Lauro César Muniz, Sérgio Marques e Walter Negrão. Foi autor também de especiais para a Globo e a Manchete.

Possui também reconhecida carreira no teatro e, como Maria Adelaide, também foi premiado. Entre suas peças estão: Tietê!Tietê!; Lua de Cetim; Feliz Ano Velho; Ópera Joyce; Florbela; As traças da Paixão, Pólvora \& Poesia, entre outras.

Os dois autores trabalharam com dois colaboradores: Lúcio Manfredi e Rodrigo Arantes do Amaral. Lúcio Manfredi já havia sido colaborador em A Casa das Sete Mulheres. Rodrigo Arantes do Amaral é filho de Maria Adelaide, formado em Arquitetura e trabalhou com ela em $J K$.

A percepção do processo de criação de Maria Adelaide com seus parceiros e colaboradores pode ser diversa, como ela descreve:

"Quem trabalha com núcleos é o pessoal que faz telenovela. Eu não faço isto. Tenho um controle absoluto sobre todos os núcleos quer esteja assinando a minissérie sozinha ou acompanhada. Quem vier trabalhar comigo já sabe disso. Essa lição aprendi com o meu mestre Silvio de Abreu.

\footnotetext{
${ }^{30}$ Tuna Dwek, Alcides Nogueira: Alma de cetim. São Paulo: Imprensa Oficial, 2004, p. 15 a 18.
} 
Eu faço a escaleta, que é o roteiro de um capítulo, cena a cena. Cada cena, onde será, qual locação, quais os personagens que estarão e qual será o assunto mencionado. Aí eu distribuo as cenas de acordo com o perfil de cada colaborador meu. Especialidade ou perfil. Eles escrevem as cenas e mandam para mim. E eu faço a edição. Junto com as outras cenas já escritas, coloco na sequiência, organizo, corto o que precisar ser cortado e faço a edição final. Aí eu mando o capítulo para o consultor. Ele devolve com as suas observações. Aí corrijo o que tiver que ser corrigido, e mando para a revisão que pode ser feita pela Carmem Righetto ou por um colaborador mais atento. Eu deixo passar muita coisa: palavras com erros de digitação ou ortografia. Eu mesma cometo erros ortográficos. Depois do capítulo revisado envio para a Globo.

No caso de Um Só Coração, o que eu costumo fazer é o seguinte: Eu escaleto, eu divido, discuto muito com o Alcides a questão da seqüência da trama. E quando termino a edição do capítulo, envio para ele antes de enviar para o consultor. Muitas vezes acontece dele também fazer a escaleta e a edição final. ${ }^{31}$

Apesar da declarada centralização do trabalho autoral, considera a teledramaturgia uma obra coletiva:

“(...). Quando se escreve para teatro ou para televisão, seu texto será intermediado pela concepção do diretor, pela interpretação dos atores e, no caso da TV, até pelo editor, que é quem faz, por assim dizer, a arte-final da minissérie ou da novela que vai para o ar. Ou seja, o texto que a gente escreve pode ser transformado, melhorado, deformado, ou engrandecido por outros profissionais. Porque uma peça de teatro e uma obra teledramatúrgica não pertencem apenas ao autor do texto. Como a dança, a música e o cinema, são artes coletivas." 32

Da mesma maneira que a emissora tem uma idéia do seu papel na cultura e

identidade nacional, a autora faz a seguinte colocação em sua biografia:

"É muito confortador sentir que a cada trabalho estamos apresentando uma página da História do Brasil e que, embora seja um produto teledramatúrgico, seja basicamente de entretenimento, pode ser um meio muito eficaz de informação. O Brasil se reconhece nas histórias que contamos, reconhece a própria História e se torna mais consciente da sua identidade."33

Porém, em outra entrevista, acrescenta que não avalia isso em termos conceituais, mas através de resultados:

“... eu nunca raciocino nestes termos conceituais. Eu avalio resultados. Então, no caso de As Sete Mulheres o que isto representou para o Rio Grande do Sul

\footnotetext{
${ }^{31}$ Entrevista concedida pela autora Maria Adelaide Amaral para esta pesquisa.

${ }^{32}$ Tuna Dwek. Maria Adelaide Amaral: a emoção libertária, op. cit. p. 121.

${ }^{33}$ Idem, p. 267.
} 
ninguém faz idéia. $\mathrm{O}$ resgate do orgulho gaúcho. As pessoas voltaram a usar lenço vermelho, houve afluxo absurdo de turismo para o Rio Grande do Sul. Quer dizer, voltaram a usar os símbolos deles, que na verdade são símbolos de identidade.

Em São Paulo, eu já te falei do afluxo a museus e de gente que, muito especificamente, entrava no MAC na Cidade Universitária e dizia: "eu quero ver o auto-retrato do Modigliani", a obra que o Ciccillo deu para a Yolanda em Roma e hoje está no MAC. Atualmente há uma comoção em Minas Gerais. As pessoas me ligam e dizem: "a gente fica muito emocionado com o JK". As pessoas ficam muito tocadas. Por isso o produto teledramatúrgico minissérie é tão eficiente: ela te pega pela emoção. Eu percebo pelos resultados o quanto é importante. E, na verdade, esta audiência enorme que nós temos, apesar do horário, ela tem a ver com essa vontade do povo de se ver, de se reconhecer. $\mathrm{O}$ público tem uma grande necessidade de se conhecer, de conhecer a sua história." ${ }^{34}$

Podemos concluir que, para a autora, a teledramaturgia promove uma forma de conhecimento prazerosa da história, além de despertar o interesse pelo passado e o resgate de valores.

\section{ATORES}

No processo de escolha do elenco de uma produção de teledramaturgia, vários fatores podem interferir. Encontrar o ator apropriado, com determinadas características físicas e talento, não é uma tarefa tão fácil. Notas diárias na imprensa dão conta das dificuldades de diretores para a escalação de elenco. Às vezes o ator escolhido já está comprometido com outra produção da casa. Em nossos dias, com a abertura de outras empresas produtoras de teledramaturgia, os atores podem estar em outra empresa. Ou podem estar envolvido em seus projetos pessoais e abrir mão de sua participação.

A Rede Globo possui atores contratados em situações diversas: alguns são por anos e outros por produção. Os atores e atrizes denominados de "estrelas da casa" normalmente se repetem em várias produções, quando solicitados. Muitos atores mal saem de uma produção e iniciam a gravação de outra. Outros ficam reservados para produções que vão ser realizadas a médio prazo, com estréia prevista para o ano seguinte.

O ator é a figura mais exposta ao público na produção de teledramaturgia. Sua exposição é maior que a do autor. A este cabe a parte intelectual do projeto, e sua exposição em eventos públicos é menor, pois está em plena fase de produção,

\footnotetext{
${ }^{34}$ Entrevista concedida pela autora Maria Adelaide Amaral para esta pesquisa.
} 
necessitando de isolamento, como qualquer escritor. Já o ator aparece enquanto personagem da trama e enquanto personagem de sua própria vida, explorada pela mídia. Há atores que conseguem projeção por sua vida pessoal, mais do que por personagens interpretadas ou qualidades artísticas. É comum mesmo que atorescelebridades sejam escalados por serem figuras de destaque na mídia.

Devemos destacar que há uma grande quantidade de atores, que procuram preservar a sua vida pessoal do olhar onipresente da imprensa. Há uma imprensa especializada em acompanhar a produção da teledramaturgia que nem sempre respeita a privacidade de seus objetos de atenção.

Quanto à seleção de atores para as produções, sabemos que há autores que escrevem personagens pensando nos intérpretes. Outros, escrevem primeiro e depois decidem, juntamente com a direção, os intérpretes das personagens, selecionando entre antigos ou novos parceiros de trabalho.

Sobre a escolha de elenco para suas produções, Maria Adelaide declara:

"Os diretores e os autores escolhem de comum acordo. Eu, de modo geral, prefiro que os diretores escolham. Prefiro exercer o poder de veto. Muitas vezes eu exerci. "Não, esta pessoa não tem nada a ver com este papel". Mas, em geral, a gente concorda." 35

Sobre a criação de papéis para determinados atores, afirma:

“..... Só papéis secundários. Por exemplo, o pai do Davi, aquele judeu velho. Eu escrevi para o Sérgio Viotti...,36

Contudo, é perceptível a participação constante de certos atores nas interpretações das personagens em suas produções, atores com os quais tem uma relação especial, que aparece em suas referências:

“...Eu, por exemplo, adoro a Ana Paula Arósio, adoro a Letícia Sabatella. Ganhou a festa. Gosto muito do Tiago Lacerda. Ele fez um esplêndido Garibaldi. Gosto muito do Mello (Luís). Adoro o Tarcisão (Tarcísio Meira). Adoro com todas as forças do meu coração a Cássia Kiss. O Calone (Antonio), a Alessandra Negrini. Paixão. Gosto muito da Deborah Evelyn, da Maria Luisa Mendonça. Adoro o Mauro Mendonça. Nas minhas minisséries sempre tem o Sérgio Viotti, Ariclê Peres, Mila Moreira, que são heranças do Cassiano Gabus

\footnotetext{
${ }^{35}$ Entrevista concedida pela autora Maria Adelaide Amaral para esta pesquisa.

${ }^{36}$ Idem.
} 
Mendes. Deixa eu ver quem mais, quais são os atores que eu gosto. É tanta gente boa que é muito difícil. É gente muito boa, é muito difícil. Eliane Giardini, eu amo de paixão. Fábio Assunção, Walmor Chagas, de Os Maias. Esse menino, o Dan, (Stulbach), está fazendo um grande trabalho. Ele começou em Os Maias fazendo o Craft, que era um personagem secundário. Adoro o Osmar Prado, tudo que ele faz é muito bom. Fez um Alencar em Os Maias maravilhoso. Olha, é difícil." 37

“... Adorei o Edson Celulari fazendo o Cicillo Matarazzo. Foi uma das melhores coisas que ele fez. Estou adorando todo mundo agora. Débora Falabella...Eu tinha uma dívida com a Débora. O papel dela em Um Só Coração era muito pequeno, não dava muita chance para ela. A Mariana Ximenes, eu gosto muito dela. Aquelas meninas de Um Só Coração. Que maravilha que eu vou ter a Camila (Morgado) agora num grande papel.... Acho que de ator está bom, não?"38

Embora a autora declare que não faz a escolha previamente, mantém o direito de opinar e vetar. E mesmo sem escrever especificamente personagens para determinados atores, acaba tendo um grupo deles repetidas vezes atuando em suas obras. Exemplificamos com alguns atores presentes em A Muralha e Um Só Coração: Letícia Sabatella, Celso Frateschi, Leandra Leal, Maria Luisa Mendonça, Mauro Mendonça, Pedro Paulo Rangel, Tarcísio Meira, Paulo José. Alguns nomes estão em uma dessas produções e em outras da autora, como por exemplo, Ana Paula Arósio, Camila Morgado, José Wilker, Luís Melo, Débora Falabella, Alessandra Negrini, entre tantos outros.

A visão de história transmitida na minissérie pode ser considerada um conjunto de visões de seus produtores. Muitos atores podem estar alienados dentro do processo de produção e do star system, que os impede de refletir sobre o que estão produzindo e a mensagem que estão passando. Outros, porém, preocupam-se em compor a personagem baseados em estudo e laboratório. A partir de uma reflexão sobre a personagem e a história na qual esta se insere, os atores emitem impressões sobre o que consideram ser a realidade daquele momento, que traz implícita uma visão de história.

Nos depoimentos do DVD de $A$ Muralha ${ }^{39}$, encontramos depoimentos de alguns atores que participaram da minissérie:

"Eu acho que A Muralha é um projeto em que a gente foi surpreendida pelo espírito dos bandeirantes. O ineditismo. A gente tinha a sensação de estar

\footnotetext{
${ }^{37}$ Idem.

${ }^{38}$ Idem.

${ }^{39}$ Maria Adelaide Amaral. A Muralha (DVD). Globo Vídeo, 2002. - Disco 1.
} 
desbravando uma história de um período tão obscuro da história do Brasil. Então, eu acho que esse espírito, ele permeia praticamente todo o tempo em que se trabalhou nessa minissérie, A Muralha. (...).Eu acho muito importante essa proximidade entre literatura e teledramaturgia, e, também contar uma história da gente.(...)"(Vera Holtz/Mãe Cândida)

"Foi feito com muito amor. Foi feito com muita paixão...Paixão pelos personagens. Paixão...Paixão pelo Brasil. Paixão pela história do nosso país. A gente tinha essa responsabilidade de contar com a máxima verdade aquele caminho percorrido pelos primeiros brasileiros.(...). Foi lindo. Foi lindo trabalhar com os xavantes. Foi lindo ver aquela força daquele povo. Aquele orgulho que os xavantes têm de si próprios. Eu falei: 'Isso a gente precisa.' Isso a minha personagem foi buscar e foi buscar com eles, lá, com os índios. Foram os índios que ensinaram isso. E eu acho que isso é uma lição que todo brasileiro devia aprender. Ter esse orgulho de ser quem se é. E o índio tem isso. Isso foi muito bacana." (Alessandra Negrini/Isabel)

"A Muralha foi uma minissérie que nos marcou a todos, que assistimos, que vimos, porque retratou um Brasil e uma situação social de um Brasil, de uma época que, eu acho, até então a gente não tinha visto de forma tão bem elaborada. Com arte, com condições de ser realizada. Porque era uma minissérie difícil. A gente teve povos indígenas brasileiros que contribuíram para a minissérie. (...)". (Letícia Sabatella/Ana)

"Gostei de ter feito A Muralha por várias razões. Uma delas é a adaptação de Maria Adelaide Amaral. O romance de Dinah Silveira de Queiroz foi escrito por ocasião do IV Centenário de São Paulo. Então, era, de certa maneira, uma louvação ao espírito empreendedor do bandeirante, pioneiro, formador dessa nação, que entra para o interior, com todo sacrifício e constrói este país que é o Brasil.(...).”(Paulo José/Padre Simão)

Nos depoimentos, todos os atores são entusiastas do projeto e de como ele pode revelar a história do Brasil. Percebemos nas falas que a visão de história contida na minissérie assume o status de uma "história real". A questão de resgate de orgulho nacional, do patriotismo, está presente em todas as falas, de maneira direta ou implícita. Há uma preocupação em resgatar a história dos primeiros brasileiros, e sabendo que a minissérie foi escrita em comemoração aos 500 Anos do Descobrimento do Brasil, podemos concluir que, para os atores, a história que produziram era a história do Brasil. Não há para eles a referência do isolamento de São Paulo e de características próprias nesse período, o que nos leva a entender que, para eles, São Paulo era o Brasil.

Esses depoimentos foram feitos especialmente para a edição em DVD da minissérie A Muralha, que foi lançada dois anos depois da exibição. Um Só Coração 
teve a edição em DVD $^{40}$ lançada no mesmo ano de exibição e não contou com depoimentos especiais para isso. Foram aproveitadas as matérias do programa Vídeo Show sobre a minissérie, não constando depoimento ou entrevista de atores que pudesse refletir uma visão de história, especialmente de São Paulo. Os depoimentos estão muito centrados nos aspectos psicológicos das personagens. O máximo que é feito em termos de aproximação histórica é mostrar a visita de alguns atores aos lugares em que suas personagens viveram.

Em todos os casos acima citados, os depoimentos foram feitos para propaganda da produção pela emissora, com o objetivo de promoção.

$\mathrm{Na}$ entrevista com Renato Scarpin focalizamos um ator que foi revelado na minissérie, interpretando Joaquim, uma personagem de destaque. Atualmente, ele está trabalhando na Rede Record, na novela Bicho do Mato. Esta emissora está investindo muito em teledramaturgia, inclusive em recursos humanos, contratando profissionais de diversas áreas e formando um banco de atores.

A personagem Joaquim retratou uma das muitas nacionalidades de imigrantes da cidade, o percurso para crescer financeiramente através do comércio e a participação de imigrantes na luta em 1932.

Diferente dos depoimentos feitos para o DVD, a possibilidade de entrevistar o ator possibilitou-nos perceber um maior grau de envolvimento na preparação deste para o papel, através do estudo sobre a imigração portuguesa. Também apresentou informações sobre as etapas de preparação da produção e como se deu a atuação de técnicos e a preparação nas cenas de batalha. ${ }^{41}$

A nossa entrevista não teve o objetivo de questionar os métodos adotados pelo ator, ou por seus colegas, para a composição de personagens. Consideramos que, atualmente, qualquer ator que queira desenvolver bem o seu trabalho, procura estudar para compor seu personagem. Não são só as personagens históricas que necessitam de preparo e pesquisa.

No caso, Renato nos deu informações exclusivamente sobre o seu processo de preparação, não possuindo informações mais completas sobre a preparação de seus colegas de elenco. Concluímos, a partir das informações dadas por ele, que a preparação

\footnotetext{
${ }^{40}$ Maria Adelaide Amaral \& Alcides Nogueira. Um Só Coração (DVD). Globo Vídeo, 2004 - Disco 6.

${ }^{41}$ Entrevista concedida pelo ator Renato Scapin para esta pesquisa.
} 
dos atores acaba sendo um processo bastante individualizado, mesmo quando há a possibilidade de workshops e encontros com os autores.

Na minissérie há cuidados com a atuação, havendo uma preparação maior para cenas através de ensaios. As personagens são mais definidas, mas há possibilidades de alterações, por variados motivos.

Nosso objetivo nesta entrevista foi coletar informações que nos pudessem ajudar a entender aspectos do processo de produção e o preparo dos atores dentro dele.

\section{DIRETORES}

Na estrutura administrativa da Rede Globo de Televisão há núcleos de direção, dedicados às diversas produções da casa. A seguir, citamos alguns exemplos de diretores de núcleo da emissora:

\begin{tabular}{|l|l|}
\hline DIRETOR DE NÚCLEO & TIPO DE PRODUÇÃO \\
\hline Ricardo Waddington & Teledramaturgia \\
\hline Jayme Monjardim & Teledramaturgia \\
\hline Marcos Paulo & Teledramaturgia \\
\hline Jorge Fernando & Teledramaturgia/Shows \\
\hline Wolf Maia & Teledramaturgia \\
\hline Luís Fernando Carvalho & Teledramaturgia \\
\hline Carlos Manga & Teledramaturgia \\
\hline Denise Saraceni & Teledramaturgia \\
\hline Denis Carvalho & Teledramaturgia \\
\hline Roberto Talma & Teledramaturgia \\
\hline Guel Arraes & Teledramturgia/Humor \\
\hline J. B. Oliveira & Shows/Auditório \\
\hline Aloísio Legei & Shows \\
\hline
\end{tabular}

Quadro construído através do site da Rede Globo de Televisão, sujeito a modificações.

Os núcleos de direção trabalham com um diretor responsável por várias produções. Podem estar simultaneamente com programas em exibição ou em preparação. O diretor de núcleo trabalha com uma equipe numerosa que envolve todos os profissionais da parte técnica, como figurino, cenografia, iluminação, câmera, efeitos 
visuais, sonoros, etc. Também há os diretores gerais, que são os diretores de fato da produção, os diretores, assistentes de direção, produtores, diretores artísticos, diretores musicais etc. $\mathrm{O}$ diretor de núcleo pode ou não estar envolvido na direção de fato da produção. Dependendo de outras produções sob sua responsabilidade, ou solicitações da emissora, acompanha o processo de outra maneira. Um exemplo é o diretor Ricardo Waddington que até recentemente tinha três produções sob a responsabilidade de seu núcleo: Sinhá Moça, que tinha como diretor geral Rogério Gomes, Malhação, que tem Roberto Vaz nessa função, enquanto ele se dedica às primeiras gravações de $P e ́$ na Jaca, a próxima "novela das sete".

A estruturação da administração em núcleos indica o caráter empresarial da atividade: produzir na e para a emissora Globo significa estar em uma linha de montagem, da qual são cobrados resultados como audiência, que é compreendida como o resultado da eficiência e da qualidade do produto, e em conseqüência, retorno financeiro através da propaganda direta ou indireta.

Nas produções que estamos estudando, verificamos que cada uma coube a um núcleo diferente.

No caso de A Muralha a direção coube ao núcleo sob a responsabilidade de Denise Saraceni, que atuou também na direção, junto de Carlos Araújo e Luís Henrique Rios. Um Só Coração teve direção de núcleo de Carlos Manga, que deixou a direção geral a cargo de Carlos Araújo. Os outros diretores foram Marcelo Travesso, Ulysses Cruz e Gustavo Fernandes.

Alguns desses profissionais haviam trabalhado antes com Maria Adelaide, como Manga, Saraceni e Carlos Araújo, sendo que este último trabalhou nos dois projetos.

No que diz respeito às relações com os diretores, Maria Adelaide declara:

"Seriam cinco minisséries cada uma alusiva a um século da História do Brasil.
Cada autor contava com seu diretor. No meu caso me coube a Denise Saraceni.
Para nós restou o século XVI. Por isso eu tive que sair da Guerra dos Emboabas
e fazer retroceder a ação histórica. Mas por razões técnicas e artísticas, acabou
sendo produzida apenas A Muralha. Eu tinha a liberdade de colocá-la no século
XVIII mas a pesquisa já estava pronta resolvi situar a ação em 1612. E foi um
sucesso enorme de crítica e audiência.
Em Um Só Coração eu queria mais uma vez a Denise ou o Jayme Monjardim.
Eu queria o Jayme, mas ele estava alocado para a novela da Glória Perez. No
fim, nem uma coisa nem outra. Ficou muito chateado. Aí eles deram para mim o
Carlos Manga e o Carlinhos Araújo. O Carlinhos Araújo eu conhecia... Eu
conhecia os dois, na verdade. O Manga tinha sido diretor de núcleo do Anjo
Mau. Eu sabia que a coisa ia ser meio complicada, muitas vezes foi. Algumas
vezes entramos em rota de colisão. Porém, nos respeitamos muito e não é 
improvável que a gente volte a trabalhar porque ele me respeita e eu o respeito.”

Percebemos que a atribuição de uma produção a um diretor depende da disponibilidade do mesmo em relação a outros projetos da emissora. Uma boa relação entre diretor e autor é fundamental para o bom andamento do trabalho. A autora não descarta as discordâncias, porém enfatiza que a relação é de respeito, o que possibilita um novo trabalho com o mesmo diretor.

\section{CONSULTORES E PESQUISADORES}

Atualmente, a maioria dos autores de televisão conta em sua equipe com um profissional responsável pela pesquisa de texto. Mesmo em novelas com temática contemporânea, dependendo do assunto, há também a necessidade de profissionais consultores para temas específicos.

Nos casos das minisséries históricas são chamados profissionais especializados na área, ou com formação e interesse pelo assunto, e pode ser alguém de confiança do autor, ou indicado pela emissora, eventualmente um aspirante a escritor. Nas que estudamos na pesquisa, houve a participação de historiadores e de instituições de pesquisa, que prestam consultoria particular para a emissora.

Em sua entrevista Maria Adelaide Amaral indicou alguns dos profissionais que trabalharam com ela em seus projetos. Entre seus pesquisadores de texto mais presentes está Carmem Righetto, que também atua com outros autores da Rede Globo.

Na parte de especialistas, para cada minissérie, é escolhido um especialista, ou mais sobre o assunto. No caso de A Muralha, ela recebeu assessoria do Museu da Pessoa. Para Um Só Coração, recebeu consultoria da Companhia da Memória, de Vladimir Sacchetta e Marcia Camargos.

Pelas informações que obtivemos, entendemos o papel do consultor como um colaborador, porém não o vemos como responsável pelo resultado final apresentado na televisão Eventualmente, as minisséries poderão apresentar aspectos que historiadores acadêmicos podem considerar errôneos, mas que dentro do processo de produção coletivo foram selecionados, em função das necessidades ficcionais. A função de consultor é colaborar com as informações históricas indicando bibliografia e os aspectos mais corretos, porém, a escolha final antes de gravar, cabe ao autor o enquadramento das observações de acordo com o andamento da trama ficcional. 
FONTES:

$\underline{\text { DVD }}$

AMARAL, Maria Adelaide. A Muralha (DVD). Globo Vídeo, 2002.

AMARAL, Maria Adelaide \& NOGUEIRA, Alcides. Um Só Coração (DVD). Globo Vídeo, 2004.

\section{ENTREVISTAS}

Entrevista com a autora Maria Adelaide Amaral.

Entrevista com o ator Renato Scarpin.

\section{REVISTAS E JORNAIS (MINISSÉRIES)}

CASTRO, Daniel. Outro Canal: Vernissage 1 e Vernissage 2. Folha de S. Paulo, 27/11/2003, caderno Ilustrada, p. E10.

LEE, Anna. Índios fazem figuração em minissérie da Globo. Folha de S. Paulo, 30/09/1999, caderno Ilustrada, p.4-4.

MACHADO, Cassiano Eleck. "Lições" de Nonê surgem em estréia póstuma. Folha de S. Paulo, 21/03/2004, caderno Ilustrada, p. E3.

caderno Ilustrada, p. E4.

Seção Livros/Lançamentos. Folha de S. Paulo, 06/12/2003,

MARON, Alexandre. Bandeirantes vão invadir tela da Globo. Folha de $S$.Paulo, 02/01/2000, caderno TV Folha, p.3.

. "A Muralha é um risco", afirma Daniel Filho. Folha de S. Paulo, 14/12/1999, caderno Ilustrada, p. 4-4.

MAUTNER, Ana Verônica. "Pátria amada". Folha de São Paulo, 18/03/2004, caderno Equilíbrio, p.12.

Não é fácil construir A Muralha. Realidade, São Paulo, n 286, ano VI, 30/jun. a 6/jul., 1968, p. 16 e 17.

Revoluções brasileiras: Revolução de 1932. São Paulo: Escala, 2004.

SÁ, Nelson de. Sem coração. Folha de S. Paulo, 11/02/2004, caderno Ilustrada, p. E8. 
SAMPAIO, João Luiz. Versões de uma mulher chamada Yolanda. O Estado de S. Paulo, 18/01/2004, Caderno 2, p. D6.

STEIN, Paulo. A Muralha: as emoções da história. Realidade, São Paulo, n 290, ano VI, 28/jul. a 03/ago., 1968, p.26.

\section{REVISTAS E JORNAIS (TELEVISÃO)}

ALMEIDA, Maria Fernanda. A novela proibida. Revista Contigo, São Paulo: Abril, 01/09/2005, edição 1563, p. 94-101.

BARTOLOMEI, Marcelo. Especialista elogia "sessão nostalgia". Folha de S. Paulo, 12/03/2006, caderno Ilustrada, p E6

CASTRO, Daniel. Globo terá manual para novelas e jornais. Folha de S. Paulo, 25/08/2006, caderno Ilustrada, p.E10.

CASTRO, Daniel \& MATTOS, Laura. Sociedade anônima . Folha de S. Paulo, 21/06/2002, c. Ilustrada, p. E1.

MATTOS, Laura. "Ser vilão está na moda". Folha de S. Paulo, 24/09/2006, caderno Ilustrada, p.E1 e E3.

NARLOCH, Leandro. A voz do Brasil. Super Interessante, São Paulo: Abril, edição 214, jun./2005, p.48-57.

NUNES, Janaína \& AUBIN, Rosana. Abaixo as fórmulas. Diário de S. Paulo, 04/09/2005, c. Já TV, ano 9, nº 461, p.8-14.

\section{SITES:}

www.biblio.com.br/Templates/biografias/dinahsilveiradequeiroz.htm

http://www.memorialdoimigrante.sp.gov.br/institucional/index.asp

http://www.orkut.com/Community.aspx?cmm=1330644

www.globo.com

http://www.editoraglobo.globo.com

http://redeglobo.globo.com/Umsocoracao/0,18529,3131,00.html

http://somlivre.com.br/ 


\section{BIBLIOGRAFIA CITADA:}

ABUD, Katia Maria. O sangue intimorato e as nobilíssimas tradições - a construção de um símbolo paulista: o bandeirante. Tese de Doutorado em História Social. São Paulo: FFLCH/USP (Departamento de História), 1985.

ALAMBERT, Francisco \& CANHÊTE, Polyana Lopes. As bienais de São Paulo: da era do museu à era dos curadores (1951-2001). São Paulo: Boitempo, 2004.

ANDRADE FILHO, Oswald de. Dia seguinte e outros dias. São Paulo: Códex, 2004.

AMARAL, Maria Adelaide. Tarsila. São Paulo: Globo, 2004.

Atas da Câmara de São Paulo. São Paulo: A Câmara, 1562-1700.

BEZERRA, Holien Gonçalves. O jogo do poder: Revolução paulista de 32. São Paulo: Moderna, 1988.

BIAL, Pedro. Roberto Marinho. Rio de Janeiro: Jorge Zahar Ed., 2004, p.178-179.

BIVAR, Antônio. Yolanda. São Paulo: A Girafa Editora, 2004.

BLAJ, Ilana. Sérgio Buarque de Holanda: historiador da cultura material. In: CANDIDO, Antonio. (org.) Sérgio Buarque de Holanda e o Brasil. São Paulo: Editora Fundação Perseu Abramo, 1998, p.29-49.

BRUNO, Ernani Silva. História e tradições da cidade de São Paulo. 3 vol. Rio de Janeiro: Livraria José Olympio Editora, 1953.

CAMARGOS, Marcia. Villa Kyrial: crônica da Belle Époque paulistana. São Paulo: Editora SENAC São Paulo, 2001.

CAMPEDELLI, Samira Youssef. A telenovela. $2^{a}$ ed. São Paulo: Ática, 1987; - Telenovela e folhetim. Dissertação de Mestrado. São Paulo: FFLCH/USP (Letras), 1983.

CANABRAVA, Alice Piffer O comércio português no Rio da Prata (1580-1640). Belo Horizonte; São Paulo : Editora Itatiaia: Editora da Universidade de São Paulo, 1984.

CANDIDO, Antonio. Aspectos sociais da literatura em S. Paulo. In: Ensaios paulistas: contribuição de O Estado de São Paulo às comemorações do IV Centenário da cidade. São Paulo: Editora Anhambi S/A, 1958.

CARNES, Mark C. (org.) Past imperfect: history according to the movies. New York: Owl Book, 1995.

CHAUVEAU, Agnès \&Philippe Tétard. Questões para a história do presente. Bauru, SP: EDUSC, 1999. 
COSTA, Emília Viotti. 1932: imagens contraditórias. São Paulo: Edições Arquivo do Estado de São Paulo, 1982.

COUCEIRO, Solange Martins. Negro na televisão de São Paulo: estudo de relações raciais. Dissertação de Mestrado em Antropologia. São Paulo: FFLCH/USP (Departamento de Ciências Sociais), 1971.

Dicionário da TV Globo, v.1: programas de dramaturgia \& entretenimento (Projeto Memória das Organizações Globo). Rio de Janeiro: Jorge Zahar Ed., 2003.

Dicionário eletrônico Houaiss de língua portuguesa 1.05 a

DONATO, João Olavo de. O capital estrangeiro e as empresas de teledifusão brasileiras: o caso da Rede Globo e PGQ - Padrão Globo de Qualidade. Tese de Doutorado em História Econômica. São Paulo: FFLCH/USP (Departamento de História), 2002.

DURAND, José Carlos. Arte, privilégio e distinção: artes plásticas, arquitetura e classe dirigente no Brasil (1855-1985). São Paulo: Perspectiva, Editora da Universidade de São Paulo, 1989.

DWEK, Tuna. Alcides Nogueira: Alma de cetim. São Paulo: Imprensa Oficial, 2004.

. Maria Adelaide Amaral: a emoção libertária. São Paulo: Imprensa Oficial do Estado de São Paulo: Cultura: Fundação Padre Anchieta, 2005.

FADUL, Anamaria (ed.). Serial fiction in TV: the latin american telenovelas: with an annotated bibliography of brazilian telenovelas. São Paulo: Núcleo de Pesquisa de Telenovelas, ECA/USP, 1992.

FERNANDES, Ismael. Memória da telenovela brasileira. $4^{\mathrm{a}}$ ed. ampl. São Paulo: Brasiliense, 1997.

FERRO, Marc. O filme: uma contra-análise da sociedade?. In: LE GOFF, Jacques. \& NORA, Pierre. História: novos objetos. $2^{\text {a }}$ ed. Rio de Janeiro: Francisco Alves, 1986. p.199-215.

Cinema e História. Rio de Janeiro: Paz e Terra, 1992.

GUERRA, Marco Antônio. Carlos Queiroz Telles: história e dramaturgia em cena (década de 70). São Paulo: Annablume, 1993.

GUIMARÃES, Hélio. A presença da literatura na televisão. Revista USP, São Paulo, 32, p.190-198, dez. /fev., 1996-97.

HAMBURGER, Esther. O Brasil antenado: A sociedade da novela. Rio de Janeiro: Jorge Zahar Ed., 2005. 
HOLANDA, Ségio Buarque de. Caminhos e fronteiras. São Paulo: Companhia das Letras, 1994.

Monções. $3^{\text {a }}$ ed. ampl. São Paulo: Brasiliense, 1990.

IGLÉSIAS, Francisco. Historiadores do Brasil: capítulos de historiografia brasileira. Rio de Janeiro: Nova Fronteira; Belo Horizonte, MG: UFMG, IPEA, 2000.

Imigração italiana no Estado de São Paulo. São Paulo: Secretaria de Estado da Cultura, Memorial do Imigrante/ Museu da Imigração, 1999. (Série Resumos, nº 1)

LEITE, Serafim. Cartas dos primeiros Jesuítas do Brasil. Comissão do IV centenário da cidade de São Paulo, 1954. Vol. I. 1538-1553;.Vol. II. 1553-1558; Vol. III. 1558-1563.

LOPES, Maria Immacolata Vassalo de. Explorações metodológicas num estudo de recepção de telenovela. In: Temas Contemporâneos em Comunicação. São Paulo: INTERCOM, 1997.

MACHADO, Alcântara. Vida e morte do bandeirante. São Paulo: Governo do Estado, 1978.

MALCHER, Maria Ataíde. A memória da telenovela: legitimação e gerenciamento. São Paulo: Alexa Cultural, Comunicação \& Cultura - Ficção Televisiva, 2003.

MARTÍN-BARBERO, Jesús \& REY, Germán. Os exercícios do ver: hegemonia audiovisual e ficção televisiva. São Paulo: Editora SENAC/SP, 2001.

MARTINS, Ana Luísa. Aí vai meu coração: cartas de Tarsila do Amaral e Anna Maria Martins para Luís Martins. São Paulo: Planeta, 2003.

MATTELART, Armand \& MATTELART, Michele. O Carnaval das imagens: a ficção na TV. São Paulo: Brasiliense, 1989.

MATTOS, Sérgio. A televisão no Brasil: 50 anos de história: (1950-2000). Salvador: Editora PAS - Edições Ianamá, 2000.

MESGRAVIS, Laima. Afonso de Escragnolle Taunay, o historiador de São Paulo. In: TAUNAY, Afonso de Escragnolle. São Paulo nos primeiros anos: ensaio da reconstituição social; São Paulo no século XVI: história da vila piratingana. São Paulo: Paz e Terra, 2003.

MICELI, Sérgio. A noite da madrinha. $2^{\mathrm{a}}$ ed. São Paulo: Perspectiva, 1982.

MONTEIRO, John Manuel. Negros da terra :índios e bandeirantes nas origens de São Paulo. São Paulo: Companhia das Letras, 1994. 
MORAES, Rubens Borba de. Bibliografia brasileira do período colonial: catálogo comentado das obras dos autores nascidos no Brasil e publicadas antes de 1808. São Paulo: IEB, 1969, p.263-271.

MORAIS, Fernando. Chatô: o rei do Brasil, a vida de Assis Chateaubriand. São Paulo: Companhia das Letras, 1994.

MORETTIN, Eduardo Victorio. Cinema e história: uma análise do filme Os Bandeirantes. Dissertação de Mestrado. São Paulo: ECA/USP (Departamento de Cinema Rádio e Televisão), 1994.

MOTTER, Maria Lourdes. Ficção e realidade: a construção do cotidiano na telenovela. São Paulo: Alexa Cultural, Comunicação e Cultura - Ficção Televisiva, 2003.

- Argumentos para o estudo da ficção A Casa das Sete Mulheres: ficção, realidade e história. ECO-PÓS, Rio de Janeiro, vol. 7, nº 1, p.85-99, jan./jul., 2004.

NOGUEIRA, Lisandro. O autor na televisão. Goiânia: Ed. da UFG; São Paulo: EDUSP, 2002.

OLIVEIRA, Mônica. de Moraes. Telenovela \& romance: Tocaia Grande na sala de aula. Dissertação de Mestrado. São Paulo: ECA/USP, 1997.

ORTIZ, Renato; BORELLI, Sílvia Helena Simões; RAMOS, José Mário Ortiz . Telenovela: história e produção. $2^{\mathrm{a}}$ ed. São Paulo: Brasiliense, 1991.

PALlOTINI, Renata. Dramaturgia de televisão. São Paulo: Editora Moderna, 1998.

PENTEADO, Yolanda. Tudo em cor-de-rosa. Rio de Janeiro: Nova Fronteira, 1976.

QUEIROZ, Dinah Silveira de. A Muralha. 8ª ed. Rio de Janeiro: Record, 2004.

Olympio Editora, 1981. - Floradas na serra. $20^{\mathrm{a}}$ ed. Rio de Janeiro: Livraria José

São Paulo através da minissérie Um Só Coração. São Paulo: Editora Globo, 2004.

SILVERMAN, Malcon. Moderna ficção brasileira 2a . Rio de Janeiro: Civilização Brasileira; Brasília: INL, 1981.

TAUNAY, Afonso de Escragnolle. São Paulo nos primeiros anos: ensaio da reconstituição social; São Paulo no século XVI: história da vila piratingana. São Paulo: Paz e Terra, 2003.

VAINFAS, Ronaldo. Trópico dos pecados: moral, sexualidade e Inquisição no Brasil. Rio de Janeiro: Campus, 1989. 
VAINFAS, Ronaldo (org.). Dicionário do Brasil Colonial (1500-1808). Rio de Janeiro: Objetiva, 2001.

WHITE, Oriana Monarca. São Paulo: território intercultural de Um Só Coração. Tese de Doutorado. São Paulo: CCA-ECA/USP, 2005.

WOLTON, Dominique. Elogio do grande público; uma teoria crítica da televisão. São Paulo: Ática, 1996. 


\section{CONCLUSÃO}

\section{O PROCESSO DE PRODUÇÃO E A CONSTRUÇÃO DA IMAGEM HISTÓRICA}

Na sociedade brasileira contemporânea, os veículos de comunicação de massa, como as emissoras de televisão desempenham papel relevante: seus produtos são temas de conversa entre pessoas, provocam reações de variados graus, sites na internet. Promovem modas no vestuário; em ornamento de casas; em bijuterias e mesmo jóias de relativo valor, e linguagem (gírias, bordões e novas palavras).

As telenovelas e as minisséries promovem agitação cultural: são objetos de colunas jornalísticas (nos grandes jornais e nas revistas de circulação semanal), periódicos especializados em televisão, revistas de acompanhamento da vida das personagens, atores e outros produtores. Também criam eventos culturais diversos.

Além dos produtos desenvolvidos pelas próprias emissoras como CDs de música e DVDs, incentivam outros produtos tais como revistas de divulgação, edição ou reedição de livros relacionados.

No desenvolvimento da pesquisa percebemos que mesmo o mundo acadêmico universitário integra-se no circuito ampliado de tais produções: são artigos analíticos, dissertações, teses e livros especializados.

O objetivo inicial deste trabalho era procurar entender qual a visão histórica construída pelas minisséries históricas e a forma pela qual elas se apropriam do conhecimento histórico.

Selecionamos duas minisséries baseadas em momentos históricos considerados significativos da história paulista, as minisséries A Muralha e Um Só Coração, ambas de autoria de Maria Adelaide Amaral.

A seleção de minisséries inspiradas em fatos da história paulista foi feita pela possibilidade de acesso à bibliografia histórica e devido ao interesse em perceber o processo de apropriação do conhecimento histórico por veículo de comunicação de massa. Pensávamos encontrar uma continuidade entre os dois projetos na imagem retratada da 
cidade, o que poderia permitir recuperar a noção histórica da cidade nas produções televisivas da autora.

Também pretendíamos captar como as narrativas televisivas e principalmente as minisséries históricas da autora se apropriam do conhecimento histórico transformado em fontes informativas.

Para os estudiosos da história, a utilização de momentos significativos do passado é sempre objeto de rejeição por apropriação indevida. Quer a apropriação se dê por narrativas folhetinescas, quer por narrativas humorísticas, a rejeição é constante.

Para o público telespectador tais disputas são irrelevantes. A atração é a trama romanesca, os heróis, heroínas, vilões e curiosidades - o passado entra como o exótico, o curioso e o diferente.

No percurso da pesquisa, elaboração e redação deste trabalho concluímos que há uma grande dificuldade em reconstituir totalmente o processo de produção da narrativa televisiva, pelo fato de ela ser a resultante da atuação de múltiplos produtores, que de variadas maneiras interferem no produto final: vestuário, iluminação, cenografia, maquiagem, atuação, direção e roteiro. Todos, de alguma maneira, acabam tendo um contato com o período histórico que a produção final se propõe retratar. Em maior ou menor grau de envolvimento com a história e a possibilidade de pesquisa, todos tomam parte no processo e agregam experiência e em alguns casos uma certa visão de história. É uma produção coletiva, que vai da empresa emissora ao editor da imagem - é uma história construída por muitas mãos e com muitos interesses, nenhum deles acadêmico.

Concluímos que a proposta inicial da pesquisa não pode ser concretizada, pois a produção coletiva implode a possibilidade de captar a forma de apropriação do conhecimento histórico, pela multiplicidade dos criadores e do processo industrial de produção. Entendemos que o passado retratado sofre influência de situações tais como: necessidades comerciais e de programação da emissora, vontade dos autores em trabalhar com determinados temas, dificuldades técnicas e financeiras, escolha de elenco, locações e reconstituições de cenários, elaboração de figurinos, entre tantas outras que não foram possíveis de indicar nesta pesquisa. 
A recepção pelo público telespectador é uma outra questão extremamente complexa, que não foi objeto deste trabalho, por já ter sido objeto de análise.

Reconhecemos hoje a especificidade do campo analítico sobre a produção televisiva. Não se aplica a este tipo de produção as mesmas propostas de análise de outras produções culturais da sociedade de massas, como o cinema.

A história é vista como argumento para a ficção, sem compromisso com uma narrativa reflexiva. É um produto da cultura de massa, que tem a função de entreter, mantendo a audiência presa na trama folhetinesca, garantindo o retorno financeiro pelo investimento realizado. Os seus produtores não descartam a qualidade ao pesquisar sobre os assuntos tratados, por entrevistar especialistas e contratar consultores para rever o resultado final.

Quanto a relação com a história, verificamos que as obras historiográficas referenciais são sempre consultadas, quer pelos autores dos roteiros, pelos outros produtores e especialmente pelos consultores, que são especialistas em temas e períodos de interesse para a produção. Documentação de época, escrita ou iconográfica, servem de fonte para elementos de cultura material: vestuário, cenografia, postura. Os elementos de cultura imaterial (idéias, comportamentos, aspirações, relacionamentos pessoais) tendem a ser anacrônicos, pois são estruturados de acordo com as regras do folhetim clássico.

Percebemos claramente a utilização das fontes históricas e historiográficas na construção das narrativas televisivas das minisséries estudadas. A relação com a cidade de São Paulo, que também era alvo de nosso interesse, revelou-se anacrônica. A historiografia do início do século XX via o passado como semente do presente da mesma forma que a narrativa televisiva. A vila de São Paulo de Piratininga se tornou a cidade de São Paulo. Bandeirantes se tornaram cafeicultores e industriais. Portugueses e índios se tornaram imigrantes e trabalhadores. Todos são paulistas, todos são bandeirantes, assim como a cidade.

A produção da narrativa televisiva de minissérie de cunho histórico é um trabalho artístico, para veículos de comunicação de massa. Seus produtores tendem a se envolver emocionalmente com a trama folhetinesca e mergulham no universo do passado, 
procurando criar e recriar vidas, que ao mesmo tempo possam refletir um mundo que já não existe e permitir a identificação com o telespectador contemporâneo, sua audiência, que garante a continuidade de sua atividade profissional. As informações históricas selecionadas podem não ser relevantes para um historiador, mas são fundamentais para a trama ficcional.

Discutir o passado construído pela narrativa televisiva é irrelevante, pois cada qual possui sua função, com objetivos diferentes. $\mathrm{O}$ importante para um historiador que trabalha com cultura e veículos de comunicação de massa é compreender o fenômeno contemporâneo, conhecer e entender a história da produção, e a partir disso, com o conhecimento das fontes, dialogar com os produtores e com a forma que o argumento histórico "dá cena", mas tendo sempre em vista que é uma ficção.

Para a cultura brasileira, a utilização de referenciais literários e históricos pelos veículos de comunicação de massa nas produções televisivas é de suma importância. A tentativa de conexão dos produtos televisivos com a cultura e a realidade fortalecem a identidade nacional, o imaginário social e auto-reconhecimento dos grupos sociais.

Do ponto de vista dos produtores a sua atuação é social e quase educacional, pois sentem-se responsáveis por despertar o interesse coletivo em temas culturais, no caso da literatura, não necessariamente só a brasileira, e nos temas históricos, que resgatam no imaginário do telespectador a identidade local e nacional.

Utilizamos como fontes um produto da indústria cultural de massa, resultante das minisséries de cunho histórica, os DVDs, mesmo sabendo que são produtos posteriores, passíveis de alteração, mas que contém dados relevantes, especialmente a ficha técnica e os bastidores. Além disso, exploramos as fontes jornalísticas - revistas e colunas especializadas em televisão. Pesquisamos também os sites específicos sobre empresa, autores, atores. Acompanhamos os 'chats' e os foruns.

A bibliografia apresentada é a citada. Lemos muitas outras obras para desenvolver a pesquisa, para compreender o universo da cultura de massa e da produção televisiva, mas na redação final não estão citadas. 
Em nosso entender, a diferença entre o conhecimento histórico e o que é divulgado nos veículos de comunicação de massa não pode ser barreira para que os historiadores não analisem os produtos contemporâneos. No tempo presente tais veículos são fontes para o conhecimento do mundo contemporâneo, da mesma forma que as outras fontes: manuscritas, impressas, iconográficas, cinematográficas e de cultura material. 


\title{
Entrevista com Maria Adelaide Amaral
}

Entrevista realizada em 20 de janeiro de 2006, iniciada às 14:35 hs, com a escritora Maria Adelaide Amaral, autora das minisséries A Muralha e Um Só Coração. Realizada por Maria Angela Raus para trabalhos acadêmicos.

\author{
E- Você autoriza a publicação desta entrevista em artigos, trabalhos acadêmicos e, futuramente, \\ possibilita... \\ Maria Adelaide - (som baixo, quase inaudível) Eu preciso ver o que vai ser publicado.
}

\section{E - Sim, com certeza.}

M.A. - A princípio, sim, mas eu gostaria de rever. Isto porque uma coisa é a linguagem falada e outra coisa é a linguagem escrita. Às vezes a linguagem falada transcrita soa estranha e às vezes primária porque se destina a ser escutada e não lida.

\section{E - Eu vou apresentar. Inclusive, eu tenho uma entrevista com o Renato Scarpim para apresentar para} ele. Eu vou deixar tudo junto e também a do Alcides. Aí fica a critério de vocês. Está bom?

M.A. - Ok.

\section{E - Como é feita a pesquisa histórica para os seus trabalhos? Qual é o seu grau de envolvimento ?}

M.A. - Total, porque para mim isto é questão de princípio. Eu nunca inicio um trabalho de época sem recorrer a uma bibliografia, sem recorrer a informações, a livros e outras fontes... No caso de A Muralha: eu fui procurar livros em sebos pois as edições estão esgotadas. De modo geral trabalho com um consultor . No caso de A Muralha trabalhei em estreita relação com o "Museu da Pessoa" e com a Íris Kantor, uma historiadora da USP.

O "Museu da Pessoa" me assessorou, passou muito material. Nos sebos do centro da cidade e consegui as atas da vila de São Paulo, que foram compiladas pelo Taunay e publicadas em 1954. Você não encontra mais isto em livraria, mas acha em bibliotecas, acha em sebos.

No caso de A Muralha, a obra original é ambientada durante a Guerra dos Emboabas. Como havia uma exigência que a época histórica fosse anterior, usei a trama amorosa do livro da Dinah Silveira de Queiroz, mas fiz retroceder a ação histórica para 1612. Então, digamos que eu comecei a falar daqueles que foram os avós dos bandeirantes, aqueles que começaram a se aventurar pelo território brasileiro, mas que na verdade tinham como objetivo mais prear índios do que ir em busca de metais ou pedras preciosas.

E foquei nos problemas da vila de São Paulo de Piratininga na época. Curiosamente, eu descobri que São Paulo plantava trigo, que era absolutamente auto-suficiente e ainda exportava o excedente para Buenos Aires. Você imagina que naquela época São Paulo exportava trigo para Buenos Aires, para Argentina? Hoje é exatamente o inverso.

Outra coisa que eu descobri também é que o principal produto de exportação era a marmelada mas já se fraudava, já se adulterava o produto. Numa determinada sessão da Câmara os vereadores mencionam essa fraude e as sanções que devem ser impostas aos fraudadores. Isto me rendeu uma boa cena. Porque quando leio História penso em termos de cena: esta situação me dá cena, esta não me dá. Porque o que fazemos numa minissérie é teledramaturgia e não documentário nem telejornalismo. E penso a His tória como possibilidade dramática: este acontecimento histórico é fundamental para a evolução do personagem, para a trajetória do personagem? É em função disto que construo minhas minisséries que são ficção televisiva livremente inspirada na realidade.

Naturalmente gosto de História. Se eu não gostasse não me preocuparia tanto em pesquisar. Pegava o livro da Dinah Silveira de Queiroz e simplesmente adaptava. Não existe, rigorosamente, na minissérie A Muralha, uma informação histórica que não possa provar ser comprovada. Além dos livros que adquiri, tive acesso a livros preciosos que a Íris me arrumou com as cartas dos jesuítas que foram publicadas em edição histórica de 1954.Então, muitas informações sobre a ação dos padres jesuítas, que não existem na obra original da Dinah Silveira de Queiroz. Eu fiz questão, absoluta, de situar a importância dos jesuítas questionando seu trabalho 
de catequese. No afã de converter, eles destruiam a cultura indígena e transmitiam aos índios doenças, algumas delas banais para os brancos, mas que causavam enorme destruição entre os índios. Uma gripe, por exemplo, podia dizimar uma aldeia.

Também falei sobre os cristãos-novos, que era um assunto sobre o qual eu sempre quis abordar. São Paulo na época era pouco importante para atrair um Visitador, mas, de qualquer maneira, resolvi tocar no assunto através do Dom Jerônimo e da Ana que também não existem na trama da Dinah Silveira de Queiroz. Já o personagem Tiago, do Leonardo Brício, encarna a ambição do jovem bandeirante já movido pela busca de metais preciosos, em oposição ao seu pai mais interessado em prear índios. Realmente os paulistas não tinham recursos para comprar escravos negros, São Paulo era muito pobre e eles se valiam dos índios, a quem chamavam negros da terra, como mão de obra.

O que faço sempre é recorrer às fontes disponíveis e ler intensamente antes de começar a escrever. Até porque, se eu não souber sobre o que eu estou falando, eu não vou conseguir escrever. Terminado o capítulo, ele vai para o consultor que vai checar as informações históricas contidas.

\section{E - No caso, foi a Íris?}

M. A. - A Íris Kantor me acompanhou em todo processo. Aliás, ela me ajudou muito na bibliografia. Os livros aos quais eu não tinha acesso, ela me emprestou. O fato é que a correspondência dos jesuítas foi vital para mim. Eu usei muitas informações contidas nestas correspondências no núcleo do padre Miguel e do padre Simão.

No caso de Um Só Coração, eu quis contar a história de São Paulo do ponto de vista da cultura, da arte e dos artistas - seus protagonistas principais. Eu desafio qualquer biógrafo de Ciccillo Matarazzo, Yolanda Penteado, Tarsila do Amaral, Mário de Andrade, Oswald de Andrade a contestar uma informação histórica e biográfica que eu tenha dado. Não estou falando de trama amorosa, embora nas tramas amorosas e conflitos dramáticos que para uma minissérie são fundamentais, tivessem sido baseados em informações escritas ou orais. E o que não aconteceu daquela forma, poderia acontecer em virtude das informações que nós obtivemos dos familiares e demais pessoas que conheceram os personagens.

Nesse sentido levantamos algumas lebres e fomos extremamente úteis aos biógrafos do Oswald e da Tarsila porque descobrimos que o Waldemar Belizário, que é o sujeito que se casa com a Patrícia Galvão para que ela ficar com o Oswald, não era apenas um modesto pintor que morava nos fundos da casa da Tarsila. Nós descobrimos que ele tinha uma obra, morou em Ilha Bela, realizou uma exposição em São Paulo e gozava da absoluta admiração de Geraldo Ferraz, que foi o segundo marido da Pagu. Essas novas informações obtivemos através de cartas e recortes de jornais que estavam em poder da viúva do Belisário em Ilha Bela e que uma amiga dela fez chegar até nós.

Essa é a vantagem da televisão que sendo veículo de grande exposição faz com que as pessoas nos procurem espontaneamente e nos dêem documentos aos quais muitas vezes o biógrafo não teve acesso porque não conheceu esta pessoa e esta pessoa também não conheceu o biógrafo. Então, as pessoas nos procuram, as pessoas nos trazem todo tipo de material informativo: cartas, documentos, artigos de jornal da época. $\mathrm{O}$ que realmente é precioso para nós.

Eu vou te dar um exemplo: muitas das informações sobre o cotidiano de Tarsila, Oswald e até da Pagu foram retirados de um original do Nonê, filho do Oswald, que era uma autobiografia poética que ele escreveu nos anos 60 e que não foi publicada porque os editores faziam restrições à forma poética. O Timochenco, o Timo $^{1}$, filho do Nonê. ${ }^{2}$, trouxe para mim, quando eu estava escrevendo a minissérie, estes originais. Quando eu vi a preciosidade daquele material e das informações que não constam em nenhuma biografia, falei "Puxa, muito obrigado!" Mas agora qual é o próximo passo? O próximo passo é publicarmos isto. E por causa da minissérie, esta autobiografia, que se chama O Dia Seguinte \& Outros Dias, acabou sendo publicada. Esta é outra grande virtude da minissérie: tornar público, ou dar visibilidade a assuntos ou pessoas que estavam na penumbra ou absolutamente esquecidos.

Voltando a Um Só Coração. Em relação à parte histórica, convidamos a Companhia da Memória e o Vladimir Sachetta e a Marcia Camargos para serem os nossos consultores. Eles ficaram responsáveis pelas informações históricas. É claro que paralelamente Alcides e eu pesquisamos muito. Evidentemente, nós resolvemos falar de 1924 de uma forma que jamais foi falada. Nós falamos da revolução de 1924 não do ponto de vista do acadêmico, pois a gente nem tem essa pretensão, mas de quem a viveu. Por exemplo: nós pegamos o livro da

\footnotetext{
${ }^{1}$ Timo de Andrade, neto de Oswald de Andrade.

${ }^{2}$ Oswald de Andrade Filho.
} 
Ecléa Bosi, Memória e Sociedade, porque muitos daqueles velhos que deram depoimento viveram a revolução essa revolução e a mostramos do ponto de vista de quem a viveu.

\section{E - As perspectivas humanas...}

M. A- Da perspectiva do humano, da perspectiva do cidadão e não da oficialidade. A perspectiva do cara que estava ali, do que significou para ele. Evidentemente, pegamos as impressões destas pessoas e as mesclamos, misturando as informações de A com B com C com D, fundimos e transfiguramos e estendemos essas experiências para alguns dos nossos personagens.

Tem também uma série de coisas que nós descobrimos e eu não sei se isto está na história. Durante a revolução de 1924 quem estava no governo de São Paulo era um camarada que não entendia nada de nada, mas que gostava de tocar piano. Aliás, ele entendia tanto do Estado que ele estava governando que eu nem me lembro mais quem era. Era Carlos de Campos. Quando falaram para ele: "Presidente" - governador na época era presidente Estado - "Presidente, precisamos combater a broca. A broca está dizimando os cafezais". Ele disse: "Eu vou mandar imediatamente um pelotão da polícia militar". Ou seja, o cara não tinha menor idéia de que se tratava de uma praga. Mas esse mesmo cidadão aí ao qual eu estou me referindo tocava piano no palácio dos Campos Elíseos quando a revolução estourou e assim continuou tocando alheio aos bombardeios. Então nós fizemos uma cena dele sendo retirado do palácio, totalmente tonto, pelo Paulo Prado... Na vida real eu não sei se foi o Paulo Prado que o tirou, mas o Paulo Prado era um homem sensato e morava perto. Essas licenças nós costumamos fazer. De qualquer maneira, ela tem base na realidade.

Em "Um só coração" abordamos a revolução de 1924 e a revolução de 1932. Falamos dos integralistas. Falamos da progressiva chegada dos judeus, da Segunda Guerra, do Getúlio, do ódio que os paulistas tinham do Getúlio. É verdade, o Getúlio era uma pessoa não muito benquista aqui.

O que mais nós falamos? Espere um pouco, porque eu não me lembro mais. Estou falando do ponto de vista da história...

\section{E - Anarquismo, através do Ernesto...}

M.A. - Através do Ernesto, isto também foi muito pesquisado.

\section{E - A própria decadência do café...}

M.A.- A decadência total. Aquela coisa da Yolanda arrancando os cafezais para plantar algodão está no livro dela. Eu não inventei nada, isto está no livro dela. São cenas de E o Vento Levou, mas foi o que ela viveu. A proposta que ela fez aos colonos de serem meeiros, de levá-los para o cartório de Leme a fim de colocar isso preto no branco. Isso tudo está na biografia dela, não inventei nada.

Falamos também da expulsão da Pagu do Partido Comunista. Troquei muitas informações com a Lúcia Teixeira Furlani, que é uma especialista em Pagu. Ela publicou um livro sobre a Pagu depois da minissérie e promoveu no MIS uma homenagem a mim, ao Alcides, e alguns atores da minissérie..

E - Voltando na questão da pesquisa. Como é selecionada a equipe de pesquisa histórica que trabalha com você? É uma indicação da Globo, ou fica por sua conta?

M.A.- Por minha conta. Só a parte visual que é deles. Eu sou a principal pesquisadora. Para quem interessar possa, eu trabalhei vinte anos na Abril Cultural como tal. Eu tenho uma grande pesquisadora que também veio da Abril, a Carmen Righetto. Ela é uma craque, nos anos $60 \mathrm{fez} \mathrm{todo} \mathrm{o} \mathrm{levantamento} \mathrm{iconográfico} \mathrm{do} \mathrm{Grandes}$ Personagens da Nossa História.

\section{E - Você fala do teatro, do Sábato Magaldi...}

M.A.- É. Nós trabalhamos muito em enciclopédias onde sempre tivemos consultores de peso. Boa parte deles da própria USP, da Universidade de São Paulo...

A cada minissérie que eu faço, existe sempre um consultor. Ele não opina sobre a ficção, mas ele opina sobre o fato histórico. "Isso não aconteceu. Isto não aconteceu assim, isto aconteceu em outro contexto. Isto foi em outro ano." A Carmem Righetto estava comigo em A Muralha e em Um Só Coração. Além dela contava com a Companhia da Memória e, quando necessário, o Vladimir e Márcia entravam em campo para pesquisar e entrevistar. No escritório deles há tudo que você possa imaginar. Eles têm um acervo bibliográfico extraordinário, principalmente de revistas. Isto é uma coisa valiosa, porque você vê a História é no momento em que ela acontece. 
E - Isto é uma coisa que eu gostaria de deixar bem claro: o teu grau de envolvimento, que você coordena, que você está à frente de toda a pesquisa. Porque existe uma idéia que você manda alguém fazer...

M.A.- O grosso da pesquisa é minha responsabilidade. Eu preciso me munir e para mim informação é munição de trabalho.

Eu não delego essa parte porque quando eu peço alguma coisa para um pesquisador sei o que estou pedindo e onde ele vai possivelmente encontrar, ou onde eventualmente pode estar a informação. Eu só consigo atirar se eu estiver bem municiada, eu só consigo escrever se eu tiver muita quantidade de informação.

Outro dia nós fomos participar de uma mesa na ECA... Você estava lá! Então, você nos viu, eu e o Alcides, em absoluto pé de igualdade, falando do Juscelino, com todos aqueles professores lá.

E - Foi mesmo, foi muito bom. Inclusive, algumas coisas eu pensei a partir dali e das lacunas que eu fui achando. Mas era uma preocupação que eu tinha, de deixar claro como vocês fazem porque eu estou estudando vocês e vou atrás deste tipo de informação. Só que as pessoas comentam outras coisas...

M.A.- Algumas pessoas falam muita merda. Certas pessoas chutam muito e inferem a partir dos seus preconceitos.

\section{E - Acontece uma coisa engraçada, quando eu falo que estou estudando...}

M.A. - A verdade é que muitas críticas estão eivadas de preconceitos. A minissérie não tem a pretensão de concorrer com o historiador. Mas irá ajudar o historiador no sentido de provocar no público o interesse pelo fato, por aquela personagem, ou pela época em que se ambienta. Tanto é que você percebe que, enquanto a minissérie está no ar, não só vende o livro que motivou ou inspirou, mas também as obras que falam sobre o tema. Isto é muito importante pois mobiliza o interesse das pessoas em se aprofundar. Nós temos tido um retorno extraordinário de pessoas que perguntam para gente onde... A "Casa das Sete Mulheres", por exemplo. Pessoas muito jovens querendo saber onde elas encontrariam mais informações sobre a Anita, sobre o Garibaldi. Inclusive gente que nem podia comprar os livros. Eu fiz um pacote e mandei para uma menina de 14 anos lá em Laguna que estava fascinada com a figura da Anita Garibaldi..

O nosso objetivo é despertar o interesse dos espectadores para aquilo que o está emocionando. É esse o nosso principal instrumento de trabalho. A emoção. Você sabe que nenhum historiador de Harvard vai questionar um filme sobre a Guerra da Secessão. Isto não existe. Nós brasileiros, porém, sabemos muito mais sobre a Guerra da Secessão americana do que sobre as nossas Guerras de Secessão, porque houve várias, começando pela Revolução Farroupilha que foi uma delas.

O melhor romance sobre a Guerra dos Farrapos é Os Varões Assinalados, de Tabajara Ruas ${ }^{3}$. É o melhor, de longe. Evidentemente, ele não tem tantos atrativos quanto A Casa das Sete Mulheres para se transformar em matéria de minissérie. Mas fiz questão absoluta de que se convidasse o Tabajara Ruas para ser nosso consultor. Eu tenho muitos livros sobre a história do Rio Grande do Sul. Eu desafio qualquer historiador do Rio Grande do Sul a questionar os fatos de cada batalha que foi à cena. Pode-se questionar a topografia do local do conflito, até porque eu não tive participação nisso. Se era assim, ou se era assado, se tinha montanha ali ou se não tinha montanha. De qualquer maneira a paisagem nunca mais será do jeito que foi há duzentos anos. A história, pelo que me foi dado ver, não é uma ciência exata. No caso de A Casa das Sete Mulheres, por exemplo, tenho uma dezena de livros que provam a importância do Garibaldi na Guerra dos Farrapos e a Sandra Jataí - que é uma grande historiadora gaúcha, pela qual eu tenho profundo respeito - questiona bastante esta importância. Você vê, então, que cada historiador tem a sua visão.

\section{E - Como você escolheu as suas parcerias e colaboradores para A Muralha e Um Só Coração?}

M.A. - A Muralha eu assino sozinha e tive colaboradores. Mas é diferente de parceria. É diferente quando você assina junto com outra pessoa de quando você não assina. A primeira vez que eu tive uma parceria de fato foi com o Walter Negrão na "Sete Mulheres". Ele estava pesquisando há dois anos sobre o Rio Grande do Sul. Então, quando eu propus as "Sete Mulheres” o Mário Lúcio Vaz, que é o Diretor Artístico lá, disse: “O Walter Negrão está pesquisando há dois anos o Rio Grande do Sul”. Aí, eu disse: "por que ele não se junta a mim?" E ele disse: "Você toparia?" Eu disse: "Não faço objeção nenhuma. Pelo contrário, eu gosto do Walter Negrão". Eu gostei muito de fazer esta parceria.

\footnotetext{
${ }^{3}$ RUAS, Tabajara. Os Varões Assinalados: romance da Guerra dos Farrapos. Porto Alegre, RS: L\&PM Editores, c1985.
} 
Quando eu propus Um Só Coração, porque ia fazer 450 anos de São Paulo, eu disse: "gente, vamos contar isso do ponto de vista da cultura. Eu já tinha escrito uma peça de teatro sobre Tarsila, já tinha sido encenada e, então, eu sabia que era uma ótima história, que tinha excelentes personagens. Aí o Mário perguntou: "Você vai escrever sozinha?" Eu disse: "Não, vou escrever com o Alcides". Nós fomos colaboradores do Silvio de Abreu. Então, era uma pessoa que eu conhecia e respeitava. Ele é um autor de teatro, uma pessoa que entende profundamente da Revolução de 1932. Ele tem uma peça sobre 1932 que se chama Paris-Belfort. O pai dele lutou na revolução de 1932, ele é de família tradicional paulista, conhece profundamente este universo. Por isso que eu acho que você deve conversar com ele. Então, eu convidei.

Eu gostei tanto da parceria que resolvi convidá-lo mais uma vez para escrever JK. Gostei muito de trabalhar com ele. Uma pessoa muito culta, muito informada, muito interessante.

E - Você tem um método, uma fórmula para escrever uma minissérie histórica ou em cada uma você acaba desenvolvendo de acordo com as necessidades?

M.A. - Cada uma tem as suas necessidades. O que as pessoas me perguntam, e você tem isso respondido, é se a Globo me propõe. Não, ela nunca propõe nada. É sempre a gente que propõe. A Globo pergunta sobre quais são os temas que a gente gostaria de falar e aí você faz a lista, ou simplesmente diz. No caso de Um Só Coração eu disse: "Vamos contar a história de São Paulo, do ponto de vista da cultura?"

E - Na tua biografia você conta que eles ligaram do departamento comercial falando que...

M.A. - Eu entrei na sala e eles perguntaram se eu tinha uma idéia de uma minissérie sobre São Paulo. A Muralha. Não, A Muralha já foi escrita. "É que o departamento comercial nos informou que São Paulo faz 450 anos". E resolveram celebrar com uma minissérie que contasse uma parte da vida da cidade.

E - Você interfere na escolha dos diretores para sua obra? Eu gostaria que você falasse um pouco sobre as equipes de direção de $A$ Muralha e Um Só Coração.

M.A. - Seriam cinco minisséries cada uma alusiva a um século da História do Brasil. Cada autor contava com seu diretor. No meu caso me coube a Denise Saraceni. Para nós restou o século XVI. Por isso eu tive que sair da Guerra dos Emboabas e fazer retroceder a ação histórica. Mas por razões técnicas e artísticas, acabou sendo produzida apenas A Muralha. Eu tinha a liberdade de colocá-la no século XVIII mas a pesquisa já estava pronta resolvi situar a ação em 1612. E foi um sucesso enorme de crítica e audiência.

Em Um Só Coração eu queria mais uma vez a Denise ou o Jayme Monjardim. Eu queria o Jayme, mas ele estava alocado para a novela da Glória Perez. No fim, nem uma coisa nem outra. Ficou muito chateado. Aí eles deram para mim o Carlos Manga e o Carlinhos Araújo. O Carlinhos Araújo eu conhecia... Eu conhecia os dois, na verdade. O Manga tinha sido diretor de núcleo do Anjo Mau. Eu sabia que a coisa ia ser meio complicada, muitas vezes foi. Algumas vezes entramos em rota de colisão. Porém, nos respeitamos muito e não é improvável que a gente volte a trabalhar porque ele me respeita e eu o respeito.

Eu li alguma coisa, quando o Jaime saiu de América, que ele ia para o JK...

M.A. - Era para o JK, mas eu não sei o que houve. Aí, o Denis me ligou e disse: "Se o Jayme não puder dirigir, você me chama?" Aí eu disse: "Claro, eu adoro você". Estou adorando o Denis. Muito legal trabalhar com ele. É uma maravilha trabalhar com ele e com a equipe dele. Evidentemente, eu tenho minha equipe de escritores, colaboradores e ele também tem a sua equipe. Muito legal.

E no $J K$ eu tenho o Ronaldo Costa Couto que é o meu consultor de história. Eu sempre tenho consultor de história.

E - Como fica a escolha do elenco?

M.A. - Os diretores e os autores escolhem de comum acordo. Eu, de modo geral, prefiro que os diretores escolham. Prefiro exercer o poder de veto. Muitas vezes eu exerci. "Não, esta pessoa não tem nada a ver com este papel". Mas, em geral, a gente concorda.

E - Você já escreveu em alguma minissérie um personagem pensando em determinado ator ou atriz? É que alguns autores gostam de trabalhar com determinados atores e escrevem, especificamente, para eles. Existe algum assim?

M.A. - Não. Só papéis secundários. Por exemplo, o pai do Davi, aquele judeu velho. Eu escrevi para o Sérgio Viotti.. 
E - Você costuma fazer alguma recomendação aos atores para eles se preparem para os personagens ou fica a cargo deles?

M.A. - Eu sempre aconselho que eles leiam sobre os personagens e sobre a época. Eu sempre digo que quem lê mais é melhor. Não basta ter talento, você precisa saber quem é a pessoa que você vai interpretar, que você vai encarnar.

E - Como são as reuniões da equipe antes de gravar, esses workshops que a gente (inaudível)

M.A. - O workshop, em geral, dura um dia. Você vai para o Rio e fica um dia inteiro lá. Eles chamam especialistas para falarem sobre o tema. Os diretores costumam fazer workshops mais específicos com os atores.

E - Fale sobre alguns atores que você gosta de trabalhar e que participaram das minisséries?

M.A. - É muito difícil. Eu, por exemplo, adoro a Ana Paula Arósio, adoro a Letícia Sabatella. Ganhou a festa. Gosto muito do Thiago Lacerda. Ele fez um esplêndido Garibaldi. Gosto muito do Melo (Luís). Adoro o Tarcisão (Tarcísio Meira). Adoro com todas as forças do meu coração a Cássia Kiss. O Calloni (Antonio), a Alessandra Negrini. Paixão. Gosto muito da Deborah Evelyn, da Maria Luisa Mendonça. Adoro o Mauro Mendonça. Nas minhas minisséries sempre tem o Sérgio Viotti, Ariclê Perez, Mila Moreira, que são heranças do Cassiano Gabus Mendes. Deixa eu ver quem mais, quais são os atores que eu gosto. É tanta gente boa que é muito difícil. É gente muito boa, é muito difícil. Eliane Giardini eu amo de paixão. Fábio Assunção. Walmor Chagas, de Os Maias. Esse menino, o Dan (Stulbach), está fazendo um grande trabalho. Ele começou em Os Maias fazendo o Craft, que era um personagem secundário. Adoro o Osmar Prado, tudo que ele faz é muito bom. Fez um Alencar em Os Maias maravilhoso. Olha, é difícil.

E - Em geral, o elenco que é escolhido se afina com você, são pessoas...

M.A. - É porque é gente que vem de trabalhos anteriores. Por exemplo, a Alessandra Negrini e o Mauro Mendonça estão comigo desde Anjo Mau.

E - A Ana Paula fez dois trabalhos...

M.A. - Os Maias e Um Só Coração. Adorei o Edson Celulari fazendo o Ciccillo Matarazzo. Foi uma das melhores coisas que ele fez na televisão. Estou adorando todo mundo agora. Débora Falabella... Eu tinha uma dívida com a Débora. O papel dela em Um Só Coração era muito pequeno, não dava muita chance para ela. A Mariana Ximenes, eu gosto muito dela. Aquelas meninas de Um Só Coração. Que maravilha que eu vou ter a Camila (Morgado), agora num grande papel (inaudível). Acho que de ator está bom, não?

E - Como você avalia o trabalho da direção e do elenco? Você costuma sugerir alguma mudança depois que começa a minissérie, que você tem acesso às imagens?

M.A. - Em geral, a gente vai assistir os primeiros capítulos e faz a edição. Agora mesmo, no $J K$, a gente fundiu o primeiro capítulo com o segundo. Alguns dos meninos que faziam JK criança eram muito irregulares. Havia cenas que eles faziam bem, cenas que eles faziam muito mal. Então gente resolveu cortar.

E - A minissérie é uma obra com roteiro finalizado. É possível que haja modificações após entrar no ar? Alguma mudança?

M.A. - Não.

E - A Muralha e Um Só Coração?

M.A. - A Muralha ficou pronta um mês e meio antes de ir para o ar. Os Maias, idem. As Sete Mulheres só não ficou porque a gente começou bem depois. Agora, no $J K$, faltam oito capítulos. Então, não há muita coisa para mexer.

E - É por que às vezes saem algumas notícias na mídia... Estou falando isto porque, na semana passada, eu li uma revista dessas Ti-Ti-Ti, Minha Novela com uma entrevista do Dan Stulbach, dizendo que o personagem dele ia sair da minissérie, mas que vai até o final. Já estava programada?

M.A. - Não sei se já estava programada ou se a gente resolveu no meio do caminho. Mas isto tem a ver com a exigência da própria história. Você vai escrevendo e aí você fala: "que tal se a gente voltasse, se a gente fizesse voltar fulano". A sinopse é o ponto de partida, nunca é o ponto de chegada. As pessoas falam com base naquilo que a gente escreve na sinopse. Mas qualquer autor sai da sinopse, você não pode ficar 
engessado. À medida que você vai escrevendo, percebendo que os personagens ganham autonomia, a história também começa a ficar autônoma. Então, você ia por aqui, mas resolve ir em frente. Isto faz parte do processo.

\section{E - Mesmo no caso da minissérie?}

M.A. - Mesmo no caso da minissérie.

E - Em Um Só Coração existiu alguma situação semelhante a essa do Dan?

M.A. - Não me lembro. O que eu me lembro é que algumas informações... Sobre o Belizário, por exemplo... O Belizário ia sumir de Um Só Coração depois que a Pagu se casava com o Oswald, mas em função das informações que nós recebemos... Que ele foi para Ilha Bela e ele era mesmo apaixonado por ela. Ele se fixou em Ilha Bela, deixou família. E o Geraldo Ferraz foi buscá-lo para fazer uma exposição em meados dos anos 30. E fizemos essa exposição na minissérie.

E - Dentro das estratégias de marketing para promoção das minisséries, até que ponto você participa? Você é solicitada para eventos de promoção? Por exemplo, festas, participação em programas da emissora?

M.A. - Eu não vou a programa de auditório. Nenhum. Posso ir ao Programa do Jô e da Ana Maria Braga. Gosto muito, por exemplo, de fazer Globo News, GNT, muito. Principalmente Globo News. Eu adoro.

A gente participa, na verdade, da festa de lançamento. Mas, não vou à festa do primeiro capítulo nem do último. Prefiro ficar na minha casa e assistir sossegada com a minha família e os meus amigos. De qualquer maneira ninguém nos força a nada. Nem a dar entrevistas.

\section{E - Mesmo no caso da emissora?}

M.A. - A emissora respeita muito os autores. E aos autores interessa promover a obra.

E - Eu gostaria que você falasse um pouco sobre a audiência. Se vocês sofrem pressões?

M.A. - Não sofremos porque a minissérie é uma obra fechada e por causa do horário que ela vai ao ar. Eu nunca sofri nenhum tipo de pressão por causa da audiência, nem quando ela foi pavorosamente baixa, como no caso de Os Maias. Pavorosamente baixa. Você não faz idéia de quanto era baixa.

A minissérie, realmente, não está sujeita a este tipo de exigência. Mas eu também faço a minissérie para agradar o público. Não me interessa também ter $14 \mathrm{em}$ audiência. Meu objetivo é atingir o maior número de telespectadores, mesmo sabendo que não será o público de uma novela por causa do horário.

E - As questões de orçamento das duas minisséries...

M.A.- Não me compete. Isto não é assunto meu.

Na verdade, eu pensei nesta pergunta pelo que vocês comentaram sobre o $J K$...

M.A.- É que o $J K$ estourou demais.

E - Então, é assim: se você tivesse alguma informação se foi muito caro A Muralha, Um Só Coração.

M.A.- Eu não sei. Não faço a menor idéia porque não lido com isso. Em geral, eles calculam em duzentos mil reais cada capítulo. Mais ou menos. Se você fizer mais ou menos cinqüenta capítulos...

E - Uma parte de A Muralha eu vou conversar com a Íris...

M.A.- Então converse.

E - Eu queria perguntar como foi dividido o seu trabalho com os colaboradores no caso de $A$ Muralha? Núcleos, você coordenava...

M.A. - Quem trabalha com núcleos é o pessoal que faz telenovela. Eu não faço isto. Tenho um controle absoluto sobre todos os núcleos quer esteja assinando a minissérie sozinha ou acompanhada. Quem vier trabalhar comigo já sabe disso. Essa lição aprendi com o meu mestre Silvio de Abreu.

Eu faço a escaleta, que é o roteiro de um capítulo, cena a cena. Cada cena, onde será, qual locação, quais os personagens que estarão e qual será o assunto mencionado. Aí eu distribuo as cenas de acordo com o perfil de cada colaborador meu. Especialidade ou perfil. Eles escrevem as cenas e mandam para mim. E eu faço a edição. Junto com as outras cenas já escritas, coloco na sequiência, organizo, corto o que precisar ser cortado e 
faço a edição final. Aí eu mando o capítulo para o consultor. Ele devolve com as suas observações. Aí corrijo o que tiver que ser corrigido, e mando para a revisão que pode ser feita pela Carmem Righetto ou por um colaborador mais atento. Eu deixo passar muita coisa: palavras com erros de digitação ou ortografia. Eu mesma cometo erros ortográficos. Depois do capítulo revisado envio para a Globo.

No caso de Um Só Coração que teve uma parceria...

M.A. - No caso de Um Só Coração, o que eu costumo fazer é o seguinte: Eu escaleto, eu divido, discuto muito com o Alcides a questão da sequiência da trama. E quando termino a edição do capítulo, envio para ele antes de enviar para o consultor. Muitas vezes acontece dele também fazer a escaleta e a edição final.

E - As versões para DVD: você participou?

M.A. - No caso de Um Só Coração o Alcides e eu, principalmente o Alcides. No caso de A Muralha foi a Denise Saraceni. Ela editou brilhantemente. No caso de Os Maias, o Luis Fernando fez. No caso de "As Sete Mulheres", o Jayme fez. No caso de Um Só Coração, nós fizemos. Fizemos absoluta questão de fazer. E JK provavelmente vai ser o Denis.

E - Alguma coisa, alguma cena da minissérie, tanto A Muralha quanto Um Só Coração, que vocês gostariam que tivesse entrado no DVD e não teve jeito ou foi tudo certo?

M.A. - Não, eu acho que o que entrou é o que deveria ter entrado. Acho que o que acontece muitas vezes a gente vê no ar uma coisa muito diferente daquilo que estava no papel. Isto nos desgosta profundamente. Então, quando a gente faz a edição do DVD e se isto está ao nosso alcance, a gente retira aquela cena que nos desagradou. Em Um Só Coração, tiramos tudo o que nos incomodava ou tudo que nós achávamos que não tinha sido gravado de acordo com o que estava escrito. Que tinha traído de alguma maneira o espírito da cena.

E - Você fez um comentário lá e eu tinha uma pergunta sobre as famílias. Houve alguma recomendação das famílias Matarazzo, Penteado, etc. ao retratar os personagens? Alguma censura de informação...

M.A. - Não existe possibilidade de censura de informação porque tudo acaba chegando até nós, na maior parte das vezes através das próprias famílias. Às vezes dá para você sentir diferenças e ressentimentos entre os membros da família e no fim as pessoas acabam te contando coisas que o outro não contou. À medida que você vai lidando com elas e captando os subtextos, joga verde para colher maduro e às vezes colhe bombásticas revelações. Mas alguns familiares contam histórias que depois nos pedem para não usar. Não no caso da Yolanda, que são uma maravilha de pessoas. Os Matarazzo também. De modo geral, sempre tendo a estabelecer excelentes relações com as famílias. Logo de cara sou muito clara com a família. E aviso: "não vou transformar o seu ente querido em um Santo. Vamos fazer justiça e tratá-lo com toda a dignidade. Mas não vamos canonizar".

Foi o caso, por exemplo, do $J K$. Eu fui até a família e a primeira coisa que coloquei foi o seguinte: "se eu não puder tocar na vida extraconjugal do $J K$ eu não vou fazer a minissérie". O que eles me pediram foi que eu tratasse disso com muita dignidade. Eu falei: "Nem pode ser diferente levando em consideração as pessoas envolvidas". Você tem que jogar claro e eles têm que autorizar por escrito. A gente tem que ter uma relação de absoluta clareza porque este é o país da liminar. Este é um país que você pode tirar de circulação um livro. As biografias têm que ser autorizada e nem as biografias autorizadas estão a salvo. Então, a gente tem que tomar extremo cuidado. Em geral, a melhor política é estabelecer uma relação de confiança com as famílias. Uma relação de confiança, uma relação de lealdade. Dependendo da família, deixamos muito claro o que vamos fazer e explicamos porque o faremos. Por conta disso você acaba estabelecendo com as pessoas relações de amizade bastante fortes. Um Só Coração me trouxe muitos amigos. Todas as famílias. A família da Dona Olívia, a família da Yolanda, a família dos Matarazzo, dos Amaral lá da Tarsila, os Andrade, o pessoal do Oswald. É muito bom isto. E agora com a família do $J K$, a família do Alckmim, do Lacerda. É muito legal isto.

E - Você viu alguma dificuldade maior em trabalhar com uma história ou uma memória próxima? Eu estou falando das críticas que você possa ter recebido em relação a $U m$ só Coração e $J K$... Você não vê uma diferença com um momento mais distante como $A$ Muralha que não tem ninguém da família ou alguém que conheceu a pessoa para questionar?

M.A. - Para mim isto não... Exatamente por esta razão que eu crio os personagens ficção, pois eles me dão uma margem de manobra muito grande para falar sobre um período, ou sobre um determinado nível social, um segmento, sem depender da autorização de ninguém. 
M.A. - Críticas, a gente sempre sofre. Tanto em relação à matéria próxima quanto a matéria remota no tempo. Fui violentamente criticada pelos Queirozianos fundamentalistas em relação às pouquíssimas licenças que eu tomei em Os Maias. Isto faz parte do nosso trabalho. Se você não está pronto para isto, é melhor mudar de ramo.

É que o retorno e as compensações positivas e as críticas positivas são infinitamente maiores e mais numerosas do que as restrições e as críticas negativas. Nenhuma crítica negativa será mais importante do que a repercussão, da satisfação de ver o povo inteiro falar do assunto. Nenhuma crítica negativa tira rá de mim a satisfação de ver no mesmo final de semana o JK como capa de duas grandes revistas, dois grandes semanários de circulação semanal, que foi a Época e a Isto É. Fora aquilo que está nas bancas sobre o JK. Nada me tirará a satisfação de ligar o rádio e de ver o tempo todo menções a minissérie ou a personagem do JK. Eu tive críticas muito positivas. Acho que eu conto nos dedos e talvez não chegue a uma mão as críticas negativas ou as observações negativas que eu tive a respeito da minissérie. Pelo menos nos jornais que eu costumo ler.

Em relação a estas críticas eu gostaria que você falasse sobre alguma que tenha marcado. Uma de jornalista, ou de historiador até, sobre Um Só Coração, ou A Muralha que você tenha achado pertinente ou que você tenha achado que o cara falou bobagem.

M.A. - Eu não lembro disso. Acho que isto reflete bem a medida da importância que eu dou para este tipo de coisa. Foi legal porque quando alguém escreveu que o cenário da batalha de Seival mostrado em "As Sete Mulheres", não tinha nada a ver com a topografia original, a Laura Mattos, da Folha de São Paulo, me entrevistou e eu declarei que a minissérie não pretendia substituir a história e nem esgotar o assunto. Quem desejasse se aprofundar que recorresse aos livros de História. Existe uma vastíssima bibliografia sobre o assunto. O mesmo poderia ser dito a respeito de qualquer outra minissérie.

O papel da mulher nas minisséries. Em outro evento que teve na ECA o Ricardo Waddington falou que novela é um produto feminino. Você não tem...

M.A. - Eu conto uma história, não estou preocupada com o papel da mulher ou do homem. Essas coisas, esses conceitos...

Eu estou perguntando porque você tem personagens femininos muito fortes, tanto em $A$ Muralha, quanto em Um Só Coração. Isto é uma característica pessoal, que você criou? Não tem uma coisa de direcionar mais para um público feminino?

M.A. - Não, eu tenho personagens masculinos muito fortes também.

Agora uma pergunta de historiador mesmo: as questões ligadas à educação e identidade nacional. $O$ meu objetivo no trabalho é mostrar que a questão de educação e história não é com o autor da minissérie, da telenovela. A gente é que vai passar isto para as pessoas. Nós historiadores e professores...

M.A. - Mas a minissérie ajuda muito. Eu acho que você deveria conversar com uma psicanalista e jornalista chamada Anna Verônica Mautner. Anota o telefone dela. Você deveria recolher o depoimento dela, pois ela tem uma teoria sobre isto. Ela diz que a novela é um produto de integração nacional. Eu acho que talvez ela tenha alguma coisa a declarar sobre esse assunto. Você deveria procurar também o professor Renato Janine Ribeiro...

Ele tem um livro...

M.A. - Ele fez crítica sobre televisão e ele tem opiniões bastante interessantes sobre o produto televisivo. Ele fez várias críticas de coisas minhas quando eu estava no ar, críticas muito pertinentes. Ele sabe da importância da televisão. Em termos ideológicos, em termos de constituição de identidade nacional mesmo. Acho que você deveria falar também com o Ivan Ângelo, que é outro que escreveu muito e bem sobre televisão. Eu sinto uma falta enorme dele. Você deveria falar com o Gabriel Priolli que é da PUC e que também escreve sobre televisão. E também com a Esther Hamburger que é da ECA. Todas estas pessoas vão ter alguma coisa muito importante a declarar. Você deveria falar com livreiros, com editores, com gente de livraria. Você 
deveria falar com escritores que tiveram os livros adaptados, ou com os agentes literários. Se você quiser, eu te passo o nome da minha.

E - É interessante. Eu ia chegar nesta questão da educação nesta da identidade nacional. Você consegue ver sua obra dentro de um projeto de identidade nacional...

M.A. - Não consigo porque eu nunca raciocino nestes termos conceituais. Eu avalio resultados. Então, no caso de As Sete Mulheres o que isto representou para o Rio Grande do Sul ninguém faz idéia. O resgate do orgulho gaúcho. As pessoas voltaram a usar lenço vermelho, houve afluxo absurdo de turismo para o Rio Grande do Sul. Quer dizer, voltaram a usar os símbolos deles, que na verdade são símbolos da sua identidade. Em São Paulo, eu já te falei do afluxo a museus e de gente que, muito especificamente, entrava no MAC na Cidade Universitária e dizia: "eu quero ver o auto-retrato do Modigliani”, a obra que o Ciccillo deu para a Yolanda em Roma e hoje está no MAC. Atualmente há uma comoção em Minas Gerais. As pessoas me ligam e dizem: "a gente fica muito emocionado com o JK". As pessoas ficam muito tocadas. Por isso o produto teledramatúrgico minissérie é tão eficiente: ele te pega pela emoção. Eu percebo pelos resultados o quanto é importante. E, na verdade, esta audiência enorme que nós temos, apesar do horário, ela tem a ver com essa vontade do povo de se ver, de se reconhecer. O público tem uma grande necessidade de se conhecer, de conhecer a sua história.

E - Uma última questão. Pensando que você é uma imigrante que foi acolhida aqui em São Paulo, veio muito jovem para cá. Essa cidade também é sua. Você trabalhou com São Paulo várias vezes, mesmo com o Silvio e agora em $A$ Muralha e em Um só Coração. Então, a imagem que você quis passar nas suas minisséries, resumidamente, e a imagem que você tem da cidade hoje.

M.A. - O que eu posso te dizer? Não são apenas as minhas obras de televisão que são ambientadas em São Paulo. Eu tenho vários romances - você deve ter o meu currículo e se não tem está no final do livro Emoção Libertária - e quase todas as minhas peças, com exceção de Chiquinha Gonzaga e Channel, são ambientadas nesta cidade. Porque eu tenho uma relação visceral, é o lugar ao qual eu pertenço. Não interessa se eu nasci em Portugal. Este é o lugar onde eu criei raízes. Não pertenço a nenhum outro lugar. Ninguém perguntou a Carmem Miranda se ela era portuguesa porque não fazia a menor diferença o fato dela ter nascido em Portugal, já que ela era, fundamentalmente, uma representante da cultura brasileira. E eu me sinto da mesma maneira. Até me deram o título de Cidadã Paulista por conta de Um Só Coração.

E - Eu não pretendia pegar pelo lado conceitual, mas por esse lado da emoção. Você vive aqui, você viu modificações. Você contou a história. Então, é nesse sentido...

M.A. - Eu conheço profundamente esta cidade, pelo menos este pedaço do centro. Eu conheço e gosto. O gostar é você aceitar com todos os defeitos.

E - O meu objetivo é mostrar a pessoa que produz a cultura e a relação que ela tem com isso, com o que ela está representando. E como São Paulo é presente e também o meu objeto final é São Paulo... Por isso eu entrei com esta questão.

Encerrando.

Fim da entrevista. 
Entrevista com Renato Scarpin

Entrevista realizada em 31 de agosto de 2005, iniciada às 14:14h, com o ator Renato Scarpin. que interpretou o personagem Joaquim na minissérie Um Só Coração.

Realizada por Maria Angela Raus para trabalhos acadêmicos. Autorizado o uso oralmente

E - Você autoriza a gravação?

RS - Sim.

E - Quer ver a transcrição?

RS - Não precisa.

E - Autoriza em estudo que eventualmente será publicado?

RS - Sim.

E - É uma entrevista aberta, você pode contribuir com as suas observações em cima das perguntas. Eu gostaria que você falasse sobre o processo de seleção dos atores para $U m$ Só Coração. Eu li que você fez também o teste para o personagem Martim.

RS - No início do processo, geralmente a Globo faz testes com os atores que pretende colocar no trabalho e escolhe um texto qualquer. No caso, foi o texto para o Martim, que era o personagem principal da minissérie e não tinham definido o ator ainda. Eles estavam testando várias opções, inclusive de idade e fotogenia, porque tinha que contracenar com a Ana Paula Arósio - há que combinar a fotogenia desse novo ator, e com o seu desempenho também. Eu, depois do teste do Martim, passados uns dias, eles me chamaram para fazer um teste especificamente para o Joaquim, e acredito que vários atores foram chamados até pela semelhança física; por exemplo, o Cássio Scapin para fazer o Santos-Dumont, depois maquiado ficou irmão gêmeo. O Pascoal da Conceição que fez o Mário de Andrade, igualzinho, então para personagens históricos, obviamente há uma procura mais específica. Personagens fictícios, como era o caso do Joaquim, não. No meu caso, o diretor, o [Carlos] Manga: "eu preciso de um ator que tenha uma doçura no olhar, mas que seja viril, porque ele vai contracenar com a Maria Fernanda Cândido, que é uma das atrizes mais lindas que tem na televisão brasileira, e eu não posso colocar qualquer ator..." e no fim calhou de ele ter gostado do teste e acabou me chamando.

E - Nos créditos o seu nome aparece como "apresentando", mas você já tinha feito outros trabalhos na Globo, participações em novelas. É alguma estratégia para promover a minissérie? Chamar a atenção para lançamento de novos atores?

RS - É, na verdade os trabalhos que eu tinha feito eram todos pequenas participações. Participação de um dia, ou de uma semana, mas eu não tinha desenvolvido um trabalho do início ao fim. Então, efetivamente, foi o primeiro trabalho em um produto da Globo. O lance de colocar como "apresentando" é obviamente para chamar atenção do público para um, ou dois, ou três atores que vão desempenhar papéis importantes na trama e que ainda não são conhecidos do grande público. Como no meu caso, eu era par romântico da Maria Fernanda e tinha outra menina, que eu não lembro o nome agora [Gabriella Hess]. Eram só dois, eu e ela, ela era a neta da... irmã da Yolanda. É, a irmã da Yolanda, isso...

E - E ela é sobrinha-neta da verdadeira Yolanda.

RS - ...da verdadeira Yolanda, exatamente. Mas também já trabalha como atriz há muito tempo. Então, é mais para chamar a atenção do público para esses novos atores que a Globo está lançando mesmo, não é para divulgar o trabalho em si, mas, sim os atores.

E - Como foi a preparação geral do elenco? Vocês participaram de workshops? 
RS - Nós tivemos uma reunião, uma primeira reunião com todo elenco, toda equipe de produção, toda equipe de direção e os dois autores, o Alcides e a Maria Adelaide. Essa reunião primeiro foi para apresentar uns aos outros - muitos não se conheciam, e nessa reunião nós tivemos algumas palestras a respeito do que seria retratado na minissérie. Algumas informações históricas foram dadas nessa reunião, tudo muito superficialmente, mais para localizar os atores. Inclusive atores como o Celulari, que entraria só lá na segunda ou terceira fase, lá no final, para fazer o Matarazzo - ele participou dessa reunião. Mas de início foi mais de apresentação mesmo e de uma localização geral de todo mundo em cada função. Quando você falou, por exemplo, que havia essa mistura entre personagens fictícios e personagens reais, tinha um menino, que eu não lembro o nome agora - aliás, dois meninos; eles eram os auxiliares do Alcides e da Adelaide. Um deles preparava todas as cenas de guerra: ele é que fazia toda essa pesquisa sobre armamento para as cenas de guerra, como a Revolução de 24, que foi gravada em Santos, depois a de 32 e tal. O outro auxiliava na parte histórica de cada personagem, do Mário de Andrade, do Oswald de Andrade, do SantosDumont e por aí vai. Então, eu não tenho certeza, mas eu acredito que tanto o Cássio, o Pascoal, o Chachá, que fizeram Santos-Dumont, o Mário e o Oswald, eles foram pesquisar por conta, foram atrás. Acho que algumas indicações da Adelaide e do Tide, que já tinham lido muita coisa sobre eles, foram repassadas para os atores, e eles foram correr atrás, mas não houve uma preparação do elenco em conjunto, isso não houve.

\section{E - Essa reunião durava quanto tempo? Um dia, dois...?}

RS - Essa reunião começou depois do almoço e terminou à noitinha. Era assim... "A minissérie é isso, ela vai começar nessa época, vai acontecer aquilo, depois vai acontecer aquilo outro, depois a gente vai estar em tal ano: aconteceu isso com o Matarazzo, aconteceu isso com o Santos-Dumont, aconteceu isso com o Oswald. Esse aqui é o sujeito que vai pesquisar as guerras, esse é o sujeito que vai pesquisar os personagens reais...". A Adelaide contou, mais ou menos, a história de vida da Yolanda para todo mundo. Mais para a gente se localizar mesmo na história, e, como era o estilo de vida da época, os costumes, essas coisas foram pontuadas nessa reunião. Mas é como eu estou te dizendo, nada muito aprofundado, tudo superficialmente, para você ter uma noção do que era e de como levar o teu trabalho na hora de gravar.

\section{E - Vocês participaram de cursos sobre história e cultura sobre o período, tirando essas reuniões?}

RS - Não, não. É como eu falei, eu acho que cada ator correu atrás das informações que ele necessitava por conta própria. Como o Joaquim era personagem fictício, o que eu fiz? Eu sabia, pela sinopse da personagem, que ele era português trasmontano, e tinha por volta de trinta anos. Vinte e cinco, trinta anos em 1924. Por praticamente duas semanas, antes de começar a gravar, depois dessa reunião, eu fui quase todo dia à Casa de Portugal, ali na Liberdade. Fui ler tudo o que eu podia achar sobre a imigração portuguesa do começo do século. "Com que espírito os imigrantes vinham para o Brasil, por que motivo vinham para o Brasil, com que riqueza?"

\section{E - Como foi sua preparação individual? Você fez algum laboratório, houve alguma orientação específica dos autores e da direção para o seu personagem?}

RS - A direção fez uma reunião com cada ator, um pouco antes das gravações começarem. Nessa reunião estavam o Manga, que era o diretor-geral da minissérie, o Carlinhos Araújo, que era o diretor que efetivamente era responsável pela execução das gravações, e o Ulisses Cruz, que era o segundo diretor. Nessa reunião eles conversavam como queriam que o ator conduzisse a personagem durante a minissérie. No meu caso, o Manga me explicou por que eu tinha sido aprovado, que ele tinha adorado o teste, que eu preenchia os pré-requisitos que ele imaginava para a personagem. Era aquela coisa do olhar cândido, mas que demonstrava uma virilidade, a ponto de conseguir contracenar com a Maria Fernanda Cândido, sem ficar menor que ela em cena. Foi nessa reunião, por exemplo, que eles definiram que nem eu, nem a Mika Lins, faríamos sotaque português, embora a gente tivesse pedido. Eles não queriam que a gente fizesse sotaque, porque, como ele explicou, a minissérie é assistida no Rio Grande do Sul e no Acre, então são vários sotaques diferentes por esse Brasil afora e o sotaque português é meio chato de entender para quem não está acostumado a ouvir. Então se definiu que nós não faríamos o sotaque e o encaminhamento para a personagem. Na reunião, eu até comentei com ele, falei do filme do Carteiro e o Poeta. Eu falei, você quer um personagem como o carteiro, como do Carteiro e o Poeta, que é humilde, que é ingênuo, mas é viril, é másculo, no sentido de rústico, e o Carlinhos falou: "é isso aí, faz assim mesmo, é isso que eu quero." Saí dessa reunião, passei quinze dias, isso por vontade própria, pesquisando sobre imigração portuguesa do início do século e final do século retrasado. Fui tentar descobrir por quê houve uma leva muito grande de imigração portuguesa nesse período. As pessoas vinham e voltavam desde o descobrimento, mas nesse 
período houve uma imigração muito forte, muito grande. Depois, eu descobri que as pessoas vinham porque em Portugal havia uma crise absurda, estava para estourar uma revolução popular - então o pessoal veio fugindo mesmo e chegava aqui sem eira nem beira. Daí fui ler sobre cultura, fiz toda uma pesquisa, acabei fazendo duas apostilas de todos os livros que eu li sobre culinária, sobre música, sobre poesia, vestimenta; ou seja, todas as informações que eu pudesse angariar nesse universo dos portugueses que aqui chegavam. Houve também uma grande pesquisa por parte do pessoal de cenário e do figurino; tanto que para o pessoal do figurino, quando me propuseram as roupas, eu até tinha mostrado umas fotos. A gente meio que chegou mais ou menos na mesma idéia de figurino.

\section{E - Sempre tem um diálogo dos atores com as equipes de produção, nesse sentido de compor o} personagem, o figurino, o cabelo...

RS - É, naquela primeira reunião que eu comentei, que houve uma palestra, naquele dia já houveram alguns laboratórios, alguns experimentos de maquiagem e cabelo, principalmente mulheres, cabelo de época porque ou corta, ou pinta, ou alonga; para homem já é mais fácil. Eu, por exemplo, usava o cabelo, sem tirar aqui, sem limpar o pescoço, que era uma característica da época. É uma bobagem, mas que tem a ver. E meu cabelo era solto e do jeito que estava, estava ótimo [risos]. De maquiagem, também nada de mais, porque eu fazia uma maquiagem no início da minissérie de passar meio que um óleo no rosto para dar aquela sensação de suor - porque no começo da minissérie o Joaquim era um trabalhador braçal, então era para dar aquela sensação de que está sempre trabalhando de sol a sol, aquela coisa toda. Mas, cabelo e maquiagem é uma coisa que é feita meio em conjunto com os maquiadores, cabeleireiros e os atores. Figurino, não. O figurinista responsável tem a sua equipe de pesquisa e ele já vem com a uma proposta praticamente fechada para o figurino do personagem. Aí depois é uma questão só de você se adequar à roupa, de falar "essa roupa não está legal, ou está, tem que ou aumentar ou diminuir; ou, não sei se essa cor é bacana. Por exemplo, o figurino do Joaquim era todo escuro e acabou sendo mudado só para cores claras. A Emília [Duncan], figurinista da minissérie, chegou um dia - eu estava provando o figurino, que era escuro ainda, e ela falou assim: "Renato, tira tudo, eu vou fazer figurino só claro para você, branco, ou cremezinho, ou pastelzinho, só cores pastéis e cores super claras porque você vai ser o herói da minissérie e herói tem que usar claro". Então há esse tipo de cuidado de informação. E, não é só isso. A pesquisa toda que eu fiz, até essa apostila que eu acabei elaborando, vários pratos - acabei dando uma de presente para o Paulo Goulart, que fazia o meu tio na minissérie, poder também estudar, porque acho que era também o interesse dele. Mas foi tudo por conta própria.

E - Você se lembra, aproximadamente, quando começaram e terminaram as gravações?

RS - O contrato, a gente fechou no meio de outubro, se eu não me engano, mas as gravações começaram em novembro de 2003. Porque o que acontece, isso em novela também é assim: os primeiros cinco capítulos, três capítulos, se você reparar, sempre são de cenas externas. Por que? Para chamar a atenção do público com imagens bonitas, uma bela fotografia. Passada essa fase dos três ou quatro primeiros capítulos, as gravações começam a se voltar para os estúdios, porque daí obviamente se barateia e se acelera muito o processo de gravação. Então, em novembro e dezembro, nós tínhamos gravados nove capítulos quando a minissérie estreou, que foi acho que dia 5 ou 6 de janeiro. Editados, ou seja, prontos para ir ao ar, deviam ter uns seis. Cinco ou seis, de frente. Mas, lógico, esses seis primeiros capítulos eram esses capítulos mais complicados, com cenas externas. Já no início da minissérie houve a Revolução de 24; então eram cenas complicadíssimas. Assim, nesses dois meses de gravação, novembro e dezembro, se produziu muito pouco em quantidade de capítulos, mas se produziu muito em quantidade de cenas complicadas a se fazer, em cenas externas. E externa depende de tempo bom, uma série de coisas, locação. Eu terminei de gravar no final de fevereiro. As gravações do resto do elenco devem ter terminado em uns vinte dias. Porque a minissérie, na verdade, ia terminar em março - ela foi esticada um pouquinho, terminou em abril. Mas as gravações devem ter terminado antes do fim do último capítulo exibido; uns quinze dias, dez dias antes.

E - Voltando para o personagem. Mais familiarizado com o Joaquim e com o contexto dele, o que você contribuiu para ele? Você já falou da pesquisa que você fez, mas da tua personalidade, Renato, há alguma característica, alguma experiência de vida que você acrescentou...

RS - Isso é engraçado, porque na minissérie, o Joaquim era apaixonado pela Ana e o Marcello Antony ficava atrapalhando a relação toda e se chamava Rodolfo. Na minha vida real, a minha namorada se chama Ana e o ex dela se chama Rodolfo. Então eu brincava com a Fê e com o Antony e dizia assim: "eu tenho todos os argumentos para te odiar, Antony, em todas as cenas que a gente vai fazer." Lógico, isso é 
brincadeira, porque eu nem conheço o ex da minha namorada, mas é, a gente... [risos]. Essas bobagenzinhas, na hora de gravar uma cena, você lembra e finge que é de verdade - então acabam acontecendo. Mas eu lembro, por exemplo, na interpretação, de algumas coisas que acontecem que são meio inexplicáveis. Logo que a gente começou a experimentar o figurino, eu dizia para Emília: "tá faltando alguma coisa, eu não sei o que. Eu acho que esse personagem... não é só o figurino, não é só a boina, tá falando alguma coisa, não sei o que pode ser". De repente, um dia eu falei para ela: "Já sei. Tá faltando uma correntinha de um santinho qualquer." Ela falou: "Por que?" Falei, "Eu não sei. Ele é português, super católico, ele é trasmontano, ele é hiper radical no sentido de valores."

\section{E - Eu revi suas cenas e tinha uma discussão no início com a Ana, com a vida que a Ana levava, com os valores dela.}

RS - Exatamente. Depois de toda essa pesquisa, lógico, você vai se infiltrando nesse universo que não é seu - isso vai te dando também uma certa percepção. Então eu falei dessa correntinha. É muito louco isso: se eu não estivesse com a correntinha, eu não conseguia fazer uma boa cena, porque eu sentia que não era o Joaquim. Outra coisa era o fato do Joaquim ser um bronco, era muito bronco. Eu fui caminhoneiro muito tempo. Então, todo o universo dos meus colegas que trabalhavam com caminhão era muito parecido com esse universo do Joaquim. É aquela coisa da palavra que vale mais do que o papel. O fio do bigode vale mais. Agir corretamente por princípio. Mesmo sendo pobre, mesmo sendo humilde, você tem princípio. Isto eu transferi para o Joaquim. O Joaquim era muito "pé no chão" e, ao mesmo tempo, era muito sonhador. Se você lembrar da história, você vai ver que o Joaquim, na verdade, não tinha nada a ver com a Ana. A Ana, para época, era uma mulher ultra moderna. Posava nua. Era um escândalo. E o Joaquim, um super retrógrado, um reacionário, firme nos seus princípios, nos seus valores. Mas ele achava que podia. E a beleza do personagem estava ali, no fato dele, mesmo sabendo, e com as pessoas em volta dele dizendo que ele não tinha condições de encarar uma relação como aquela, ele apostou e foi com tudo até que conseguiu se casar com a Ana. É esta coisa do acreditar que é possível que tem no filme $O$ Carteiro e o Poeta, e que tem de certa forma na minha vida... Às vezes, eu brinco: "a gente pode tudo, porque ontem eu estava na estrada com um caminhão e hoje eu estou na tela da Globo, em um produto classe A da Globo". Quer dizer, uma mudança radical de vida. Se alguém me dissesse há dez anos atrás, quinze anos atrás que eu estaria na Globo... Eu nem queria ser ator nessa época. Então, é muito louco como você, batalhando os teus sonhos, acaba conquistando. E o Joaquim tinha isso - essa força de vontade, essa crença. Eu me lembro de uma fala do Joaquim com o Paulo Goulart, quando tinha estourado uma revolução...

E - A de 1924, não foi?

RS - É, que saquearam tudo. Depois, quando a gente volta e vê tudo arrebentado, tudo estourado, tal.... Ele dizia: "Acabou, não tem mais nada, perdemos tudo". Eu dizia: "Tio, não, a gente tem braço para trabalhar. Vamos levantar, vamos fazer, eu vou vender frutas. A gente vai fazer". Isto tinha muito a ver com a minha vida pessoal. É a história do meu pai que também já teve uma grande empresa, já perdeu, já montou outra e já perdeu. E ele está sempre tentando dar certo e eu do lado dele, "Vamos lá, pai". Então, esta cena me lembrou muito a minha vida. -E lógico que na hora de eu dar essa fala eu tinha toda uma carga emocional pessoal que eu emprestei para a personagem. Isso rolou várias vezes. Acho que, até por isso, o Joaquim foi um personagem que deu muito certo, caiu no gosto do público. As pessoas todas torciam pelo Joaquim. E você assistiu este filme, O Carteiro e o Poeta?

\section{E - Assisti, mas...}

RS - Há muito tempo? Para mim, é um dos filmes mais lindos que o cinema já produziu. É estilo Cinema Paradiso - uma coisa que é humana até o cerne. É maravilhoso. O carteiro é aquele sujeito bronco, filho de um pescador, mal sabe ler e escrever. Ele conhece o Neruda, fica amigo do Neruda... Eu me lembro que tinha uma cena que eu achava muito engraçada: ele pede para o Neruda fazer um poema para ele entregar para a menina que ele gosta. E o Neruda fala que não é assim. "Não é assim, não pode, não faço, não faço". E o carteiro fica tão bravo e ele fala assim - porque o Neruda estava concorrendo ao Nobel - "com esse egoísmo você nunca vai ganhar o Nobel". E fala com o Neruda como se estivesse falando com qualquer um. Essa falta de discernimento, de quem é quem, é que eu coloquei muito no Joaquim. Nessa cena que você comentou - eu me lembro de uma dica do Paulo Goulart que mudou a cena. Na cena que ele xinga a Ana, o Paulo Goulart me falou... Aliás, fique registrado que eu devo muito a ele nessa minissérie. O Paulo me disse uma coisa que eu usei para a cena e ficou muito bacana: "quando você gosta muito de alguém, este alguém te magoa e você quer ofender, é difícil para você xingar com raiva só. Você está com raiva, mas é difícil 
passar pela garganta o palavrão e externar isto para a outra pessoa. Então, durante a cena em que ela fala 'pois é, eu já me deitei, não sei o que', ele fala: 'Sabe o que você é? Você é... uma barregã.' Dói para ele xingá-la.” Nem sei porque eu estou falando isto...

\section{E - É porque eu lembrei da cena e você estava falando do Paulo Goulart, que ele te ajudou e que ele falou isto e... \\ RS - Essas coisinhas que a gente coloca na interpretação que, obviamente, dão o brilho para a personagem. Dão vida, na verdade. Porque isto é uma reação humana.}

E - Houve alguma modificação do seu personagem ou de alguma trama que ele participava que não estava prevista no roteiro inicial? Você conhecia toda a história do Joaquim antes de começar a gravar?

RS - Inicialmente, o Joaquim ia passar pelas três fases da minissérie. Ele ia morrer com sessenta e poucos anos, junto com a Ana. No decorrer da minissérie foi modificado o direcionamento do personagem, onde ele iria para a guerra e morreria na Revolução de 1932. O que, de fato, acabou acontecendo. O Joaquim, que era um personagem secundário, acabou se tornando um personagem de destaque na minissérie. Por isso, também, fui escolhido para morrer na minissérie, como o herói que doa a vida em função de uma causa. $\mathrm{O}$ que era bem a cara dele também.

\section{E - Como os autores e a direção avaliam o trabalho dos atores?}

RS - Pelo IBOPE e as críticas que saem em revistas e jornais. Ouvindo muitas pessoas. Eu me lembro de uma ocasião em que estava gravando, e quem estava dirigindo era o Carlinhos Araújo. A gente fez a cena e depois eu fui assistir no vídeo. Aí eu olhei e disse: “Carlinhos, eu estou piscando demais. Não dá para refazer a cena? Eu estou piscando demais." Ele ficou louco comigo: "Eu sou o diretor. Se a cena está gravada e eu não pedi para repetir é porque a cena está boa." Eu falei: "Nunca mais eu falo nada". Aí brinquei com ele: "Não está mais aqui quem falou". Mas ele viu que eu fiz um comentário totalmente inocente e ele me deu uma esculhambada. Porque na Globo tem muito disso: cada um exerce a sua função. É por isso que a Globo funciona. Cada um exerce a sua função e é responsável por ela. O que ele deixou bem claro era: "eu sou diretor e a minha função é dizer se a cena está boa ou não. Eu estou dizendo que a cena está boa e fim de papo". Depois eu até brinquei com ele e ele deu risada. Obviamente, isso não estressou nada. Mas foi um aprendizado, de que o diretor, na hora em que ele está dirigindo e a cena está gravada, o feeling dele é o principal filtro. Quando ele deixa passar, pode ser por vários motivos: um, porque a cena está ótima mesmo; outro porque ele acha que determinado ator não vai desempenhar melhor do que acabou de fazer - e então vai daquele jeito mesmo. Depois é a sociedade que acaba criticando o trabalho do ator. São as revistas, os jornais, os críticos de TV, os programas que comentam. Na minissérie há uma diferença com a novela, porque a novela já é um produto industrial: se grava muito rápido, se grava muita coisa e não se tem tempo para ficar repetindo dez vezes a mesma cena. $\mathrm{Na}$ minissérie, que é um produto muito mais elaborado, muito mais caro, há um cuidado maior. Por isso até que o Carlinhos Araújo foi escolhido, porque ele é um diretor que antes de gravar qualquer cena, senta, conversa, explica, analisa. Então, quando você vai para o set, você vai praticamente pronto, sabendo o que tem que fazer. É diferente da novela em que o diretor não tem esse tempo. Ele chega, marca e fala "ação, gravando" e seja o que Deus quiser.

Aconteceu uma coisa muito bacana no início da minissérie, com toda a crítica do primeiro dia da minissérie, elogiando praticamente tudo, mas falando mal do Erick Marmo. No meu ponto de vista, foi até injusto com o Erick, porque era o primeiro capítulo e o pessoal não teve dó: meteu o pau mesmo. O Manga fez uma das coisas mais lindas que eu já vi. Ele chamou toda a equipe para dentro do estúdio - ator, diretor, cenógrafo. Do cara que serve o cafezinho a ele, que era o comandante-chefe - reúne todo mundo no estúdio, senta na poltrona do cenário do coronel Totonho, manda o Erick sentar do lado dele... E aquela tensão no ar... Meu Deus do céu... o que o Manga vai fazer? O Manga tira um papel do bolso e começa a ler uma crítica. "É ridículo, é indecente, o trabalho dele é um desserviço ao país, e um desserviço ao cinema, a televisão. E foi todo mundo ficando cada vez mais encolhido. O Erick, coitado, sentado do lado do Manga, parecia o Pequeno Polegar. Ele ia diminuindo, diminuindo... No final da crítica, ele dizia: "portanto, Carlos Manga deveria procurar qualquer outro trabalho que não o cinema, porque ele é o pior cineasta do mundo. Rio de Janeiro, não sei quando de 1956." Ele olha para todo mundo e diz: "Esta foi a primeira crítica que eu recebi na minha vida. Trinta anos, cinqüenta anos depois, eu estou aqui, dirigindo a minissérie de maior audiência 
da história da Globo. Portanto, meu querido...”, ele virou para o Erick e disse, “... só te peço uma coisa: faça com verdade". Todo mundo se pôs a chorar porque foi uma atitude maravilhosa dele. O Erick, obviamente, ficou muito mal. Mas depois disso, rolou um certo "vamos lá, vamos lá". Todo mundo, uniu o time. O próprio trabalho do Erick começou a melhorar. Mas isso em função destas críticas que saíram pelo Brasil afora. Então, são essas pessoas que acabam fazendo a crítica e também direcionando o futuro de uma personagem em um produto de televisão. Às vezes a crítica começa a falar muito bem, como agora estão falando muito bem da filha da Glória Pires. Então, começa a se dar mais ênfase para relação dela. É mais ou menos assim que funciona.

E - Mas nessa avaliação, a partir do momento em que os autores recebem e-mails, lêem as críticas, enfim, como eles repassam isto para vocês? Você deu o exemplo do que o Manga fez, mas, por exemplo, às vezes vinha uma anotação no roteiro que vocês recebiam? Alguma dica, um elogio? Alguma mudança que eles estavam pedindo na interpretação?

RS - Não, isto não existe. O que acontece, às vezes, é do autor acabar ligando para você... Como o Alcides fez na cena da morte do Joaquim. No dia que acabou a cena, o Alcides ligou para mim, elogiou, disse que estava recebendo e-mails, cartas e telefonemas. Todos comovidos com a cena. Isso ele me passou pessoalmente, por telefone. Mas não tem muito disso. Na Globo tem uma coisa engraçada. Um dos termômetros desse trabalho é a quantidade de cartas que o ator recebe. Esse é um termômetro. Mas não tem muito essa coisa de... Só se o ator tiver muito ruim. Aí, provavelmente... a gente diz: "ou o personagem vai para a Europa, ou vai morrer." Acontece alguma coisa assim...

\section{E - Eu gostaria que você falasse sobre as gravações das cenas de 1932. Onde elas foram feitas? Como era a preparação dos atores?}

RS - Para as cenas da guerra de 1932, o que a gente tinha lá eram alguns meninos que faziam o dublê. Tinham uns meninos que eram de uma turma de dublês que faziam todas as cenas de explosões, que o cara saia voando, caía e se arrebentava. Esses indicavam para os atores o manejo de arma, manejo de espingarda, de revólver, de granada. Essas orientações nós tivemos lá.

\section{E - Por esses dublês?}

RS - Por esses dublês, que são especialistas nisso. Então, em uma cena que rolava uma explosão, o cara sai voando...

As cenas da guerra foram gravadas, todas, em uma fazenda em Minas Gerais, perto de Juiz de Fora. Acho que a Globo já usou aquela locação para outros trabalhos. Ali tinha um túnel perto de uma linha de trem, que continua a ser o túnel da Mantiqueira, que aquele grupo de soldados da revolução estava lá para defender. Difícil, por exemplo, foi, na cena da morte do Joaquim, todos os efeitos especiais, de tiros. O Joaquim ia morrer com uma rajada de metralhadoras, o que dava, acho que doze tiros que ele ia levar. Enquanto a gente gravava outras cenas, esta equipe de efeitos especiais passou o dia preparando a roupa, o uniforme do Joaquim... da morte, que era cheio de explosivos... Eles passaram o dia preparando essa roupa da morte do Joaquim. Tinha explosivos pela roupa inteira, pela calça... Eu lembro que aquele era o último dia que eu ia gravar. Eu estava com uma viagem marcada para Santa Catarina e tinha que gravar antes do pôr do sol de qualquer maneira, em função da luz. Então, quase às 5 horas da tarde, lá na Serra, começou a baixar a luz rapidinho e a gente teve que gravar às pressas. Vesti aquela roupa - que era um uniforme normal, todo preparado - e passavam por dentro da calça os fios dos explosivos que, todos juntos, davam mais ou menos a grossura de um pulso... E esses fios todos estavam ligados em um aparelho que fazia explodir, espirrar o sangue, e tal. Só que, do aparelho até mim a gente tinha um metro e meio de fio. E a cena era o Joaquim correndo, tomando os tiros e caindo. E a gente não podia repetir - esse era o grande problema. Eles passaram um dia para preparar a roupa e iam levar mais umas quatro horas, no mínimo, para preparar uma outra roupa se fosse o caso de regravar a cena. E só poderíamos fazer no outro dia porque a luz estava caindo. Então, era um desespero; tinham quase duzentas pessoas lá e na hora de gravar esta cena foi aquele silêncio geral. O Marcelo disse: "Vamos lá, vamos lá. Atenção, gravando". E eu falei: "Marcelo, pára." Ele falou: "O que foi?" Eu falei: "Marcelo, eu sei que o sol... mais dois minutos não tem mais sol. Mas eu preciso de um segundo para me concentrar". E o Marcelo foi um anjo. Ele tremia de nervoso, mas falou: "Está bom. Silêncio". Olha, a minha responsabilidade: você sozinho, a câmera na sua frente. Duzentas pessoas em sua volta, todas te olhando, esperando você gravar a cena. Todas em silêncio porque o diretor mandou, o ator pediu que precisava de um segundo para se concentrar. E era um saco porque eu 
tinha que vir correndo, tomar os tiros e cair. Só que não era eu que acionava os explosivos. Era o técnico. Então, eu tinha que reagir depois dos explosivos, mas com outra dificuldade. Eu não podia correr porque só tinha um metro e meio de fio. Acho que tinha menos... Acho que tinha um metro. Eu me lembro que eu podia dar um passo. E no fim acabou dando tudo certo. Eu falei: "vamos lá". Dei o passo e o cara explodiu tudo. Então, teve esta preparação para todos atores que tomaram tiro, como reagir... Mas isso era lá com os dublês, que estavam contratados para isso.

E - Em média, quantas cenas vocês gravaram nessa fazenda? Quantas por dia?

RS - A gente ficou lá uns quatro ou cinco dias. A gente gravava por dia, dependendo da personagem, mas se gravava no máximo dez cenas. Este é o problema da locação: posicionar câmera, aí chove, não tem luz, sol, passa avião... Então, é muito complicado. E as tomadas feitas para a guerra de 32, se você assistir, são tomadas lindas. Aí tem que conciliar o tempo da explosão com o tempo do tiro e com o tempo da reação do ator. Estas coisas todas demoram. Eu não tenho certeza, mas acho que não se gravava mais do que dez cenas por dia.

E - Em geral, na minissérie todas as cenas acabam sendo ensaiadas, ou só uma de revolução, que é uma elaboração maior, mais complicada, exige mais pessoas?

RS - Na minissérie, praticamente todas as cenas eram ensaiadas. Ensaiadas entre aspas... A gente fazia a cena uma vez - era um ensaio para os atores, para o iluminador, para o cameraman e para o sonoplasta; para ver se o boom não estava vazando, para ver se, da posição que ele estava, conseguia captar o som perfeitamente, se a luz estava iluminando direito, se a câmera tinha os recursos para, da posição que ela estava captar a cena e para os atores saberem a movimentação dentro dela. Feito isto uma vez, já ia direto para a gravação, salvo cenas um pouco mais elaboradas. Por exemplo: teve uma cena em que eu não quis ensaiar. A gente fez marcação, só. Mas eu não quis ensaiar. Nem eu, nem a Maria Fernanda. Era uma cena em que ela conta que foi estuprada. Naquela cena a gente só se posicionou, mas não fez a cena. Mas também a gente conversou muito com o diretor. É que aquela é uma cena que exigia emoção, então não dá muito para você no ensaio... Se você no ensaio você se emociona, na hora de começar a cena você já está com o olho...

E - Vermelho. Você já entrou, já saiu e vai ter que voltar para o personagem.

RS - É, fica um pouco complicado. Eu não quis ensaiar e nem a Maria Fernanda. Mas houve muita conversa com o diretor, coisa que em novela não acontece. Em novela, o diretor chega: "Você entra aqui, faz aqui, senta aqui, pega o copo, bebe, fala, levanta, olha a janela, dá tchau e vai embora. Ação". É mais ou menos assim que funciona. Na minissérie não. Mas também, isso é um pouco a característica do Carlinhos Araújo. Ele gosta de falar com o ator, o que é fantástico, porque você, como ator se sente protegido e também se sente mais seguro, porque você sabe exatamente aonde ele quer que você chegue.

\section{E - O Joaquim morre como um herói da revolução. Como você avalia o seu personagem dentro da história?}

RS - Talvez o Joaquim tenha feito o sucesso que fez pelo fato dele ser o espelho de boa parte da sociedade, das pessoas que chegaram aqui, e de hoje em dia mesmo. Hoje a situação do Brasil está complicada. Está complicado você arrumar emprego. Quer dizer, o desemprego está aí para milhões de pessoas. A gente vive uma recessão disfarçada. E o Joaquim é aquele cara que acredita que o trabalho rende, que você, trabalhando, conquista. Mais ou menos como este slogan do governo: "Sou brasileiro e não desisto nunca." Mas assim como o Joaquim, tem muita gente hoje que não consegue emprego e acaba montando a barraquinha de cachorro quente não sei onde. Gente com diploma... Eu, por exemplo, quando trabalhava com caminhão, conheci dois caminhoneiros que eram formados. Um era advogado e o outro era médico. $\mathrm{E}$ foram trabalhar na estrada. O brasileiro tem muito disso. Ele dá jeito, ele precisa sobreviver. O Joaquim era o arquétipo dessas pessoas que batalham, que acreditam que o trabalho honesto, com o suor do rosto, vai vir recompensado depois. E a morte dele, da forma que foi feita, dando esta conotação heróica, épica, demonstra também a questão dos princípios. Eu lembro da cena: ele vai porque vê um companheiro sendo metralhado e fala "eu vou buscar o cara". Ele era humano. Ele era bom. E as pessoas torcem pelos mocinhos. É uma pena que a grande maioria não seja como ele. Se a grande maioria fosse como ele, a gente - o Brasil - estaria infinitamente melhor.

\section{E - Com certeza.}


RS - Mas você olha a CPI e você vê exatamente que tipo de pessoa... As pessoas estão muito mais para Rodolfo do que para Joaquim.

E - Quais eram as orientações dos autores e da direção para o elenco no período de preparação?

RS - Nessa reunião que o Manga e o Carlinhos fizeram com cada ator - e o Ulisses estava junto - na qual eles falavam como era o personagem, como eles queriam que você conduzisse o personagem e tudo mais... No meu caso foi assim: tanto o Carlinhos quanto o Ulisses me indicaram alguns livros para pesquisar nada com valor histórico, mas para pesquisar emoções e reações da personagem. Eu li um do Eça de Queiroz... Eu esqueci agora... Eu não vou lembrar, mas eram dois livros que contavam histórias parecidas, de amores impossíveis, ou de amores entre a princesa e o plebeu, que se apaixonavam, em que ele fazia de tudo para, no final, ficar com ela. Era mais ou menos a história do Joaquim com a Ana. Um deles era sobre um cara que passou a vida inteira amando e escrevendo poesia. Tudo que ele via no mundo era sob a ótica do amor dele pela mulher. Então, ele tinha uma visão toda poética do mundo. Tudo, para ele, relacionava-se a este grande amor. E, de certa forma, também o Joaquim tinha um pouco disso com a Ana. Quando ele via a Ana ou estava com a Ana, o mundo ficava meio cor-de-rosa para ele. Podia estar lá se ferrando na mercearia do tio, mas tudo ficava bonito quando a Ana chegava. Era mais ou menos isso. Então, essa orientação foi passada pela direção. Acredito que para cada um dos atores. Para mim, foi feito assim.

E - Na época, vocês chegaram a divulgar a minissérie em outros programas da Globo? No Vídeo Show sim, já que eles sempre invadem e fazem as matérias. Mas Faustão, ou Fantástico comentaram alguma coisa? Você lembra?

RS - Não. Até o Faustão... Eu acho que ele fez alguma coisa com o Erik e a Ana Paula Arósio, no início. Mas eu acho que não foi feito...

E - Não foi feito com todo elenco, como se faz com novelas?

RS - Não foi. Por exemplo, hoje em dia a América - todo santo Domingo... porque eles precisam alavancar o IBOPE de América, porque não está nada bom. Mas da minissérie... Acho que A Casa das Sete Mulheres teve muito mais destaque neste sentido do que Um Só Coração. É engraçado, porque mesmo contando a história de São Paulo, foi a minissérie que mais deu IBOPE... Ainda hoje se lembra mais de A Casa das Sete Mulheres do que de Um Só Coração. E se você vê a minissérie deste ano, Mad Maria, passou batido. É uma história linda, a história da Madeira Mamoré. Mas passou batido. 


\section{Ficha técnica da minissérie $A$ Muralha}

Minissérie de: Maria Adelaide Amaral

Escrita por: Maria Adelaide Amaral, João Emanuel Carneiro e Vicent Villari

Dirigida por: Carlos Araújo, Luís Henrique Rios e Denise Saraceni

Direção Geral: Denise Saraceni e Carlos Araújo

Direção de Fotografia: Elton Menezes

Direção Musical: Mariozinho Rocha

Diretor Executivo e de Produção: Eduardo Figueira

Direção de Núcleo: Denise Saraceni

Cenografia: May Martins, Fernando Schimidt, Maurício Rolfs

Figurino: Emília Duncan, Cao

Caracterização: Marlene Moura, Sônia Pena,Marcello Ancilotti

Direção de Arte: Lia Renha

Produção de Arte: Luiz fernando Cardoso, Andrea Panafiel

Pesquisa Histórica: Myriam Mendes, Leila Melo

Iluminação: Jandir Magalhães

Assistentes de Direção: Abelardo Lustosa, Cecília Amado, Luciana Oliveira

Consultoria de Linguagem: Íris gomes da Costa

Produção de Elenco: Malu Fontenelle

Produção de Engenharia:Marcos Senna

Abertura: Central Globo de Comunicação

Câmeras - externa e estúdio: Lúcio Sibaldi, Edson Giachetto, Ricardo Fuentes, Antonio Laport, Luiz C.

Maidana, Carlos Monnerat, Romildo Inácio, João Ricardo

Direção de Imagem: Milton Valinho

Efeitos Visuais: Gerald Kholler, Chico Mauro

Efeitos Especiais: Farfan, Vitor Klein

Edição: Paulo H. Farias, Roberto Mariano

Sonorização: Octavio Lacerda, Francisco Sales, Carlos Alberto 
Continuidade: Sônia Branco, Maria Eugênia Lopes, Aurora Chaves, Fernanda Borges, Elba Kurosawa

Música de Abertura: Ouverture - Floresta do Amazonas (Heitor Villa-Lobos)

Produção Musical: Ségio Saraceni

Coordenação de Produção: Carlos Galvanni, Silvana Gabbardo

Gerência de Produção: Carla Mendonça

Elenco (em ordem alfabética):

Ada Chaseliov (Leonor)

Alessandra Negrini (Isabel Olinto)

Alexandre Borges (Guilherme Schetz)

André Gonçalves (Apingorá)

Ângelo Paes Leme (Vasco Antunes)

Antonio Castiglioni

Antonio de Bonis

Antonio Gonzales

Arnaldo Marquez

Beto Bellini

Bumba (Genoveva)

Cacá Carvalho (Frei Carmelo)

Caco Ciocler (Bento Coutinho)

Carlos Eduardo Dolabella (João Antunes)

Cecil Thiré (Dom Bartolomeu)

Cesário Augusto

Celso Frateschi (Afonso Góis)

Cláudia Ohana (Antônia)

Deborah Evelyn (Basília Olinto Góis)

Edwin Luisi (Dom Gonçalo)

Edwirges Ribeiro (Genoveva)

Elias Andreato (Pai de Ana)

Emanuelle Soncini

Emiliano Queiroz (Falcão)

Enrique Díaz (Aimbé)

Hélio Fonseca

Henrique Lima

Irving São Paulo

James Martins

João Pedro Roriz (Parati)

José de Abreu (Inquisidor)

José Wilker (Dom Diogo)

Leandra Leal (Beatriz Ataide)

Leonardo Brício (Tiago Olinto)

Leonardo Medeiros (Leonel Olinto)

Letícia Sabatella (Ana Cardoso)

Luis Melo (Dom Manuel)

Macsuara

Marcos Fuchs

Maria Luisa Mendonça (Margarida Olinto)

Maria Maya (Moatira)

Matheus Nachtergaele (Padre Miguel)

Mauro Mendonça (Dom Brás Olinto) 
Michauaka

Mira Palheta (Judia)

Mônica Torres (Joana)

Patrick De Oliveira (Tuiú)

Paulo José (Padre Simão)

Pedro Fuchs

Pedro Paulo Rangel (Davidão)

Regiane Alves (Rosália Olinto)

Ridan Pires

Rita Martins

Roberto Lopes

Sandro Rocha

Sérgio Fanchi

Sérgio Mamberti (Dom Cristóvão)

Sérgio Stern

Stênio Garcia (Caraíba)

Silvia Nobre

Tarcísio Meira (Dom Jerônimo Taveira)

Vera Holtz (Mãe Cândida Olinto)

Viviam Vieira 


\section{Ficha técnica da minissérie Um Só Coração}

Autores: Maria Adelaide Amaral e Alcides Nogueira

Colaboradores: Lúcio Manfredi e Rodrigo A. do Amaral

Direção de Núcleo: Carlos Manga Direção Geral Carlos Araújo

Direção: Marcelo Travesso e Ulysses Cruz Assistentes de Direção Gustavo Fernandez, Noa Bressane, Federico Bonani e Felipe Louzada

Direção de Produção: Aluizio Augusto Gerente de Produção Verônica Esteves Cenografia Raul Travassos, Gilson Santos e Isabela Urman

Cenógrafos Assistentes: Ana Paula, Antunes Lopes, Claudiney Barino, Gil mar Ventura, Gioconda da Costa Ferreira, Luis Cláudio Velho, Márcio Coelho Fontes, Marcos Aurélio Nascimento Sobrinho e Silvana Machado da Silva

Figurino: Emilia Duncan

Figurinistas Assistentes: Marie Salles, Jussara Magalhães, Carmen Rose de Farias, Daniela Christino, Julia Brant e Maria Luiza Grabowski

Equipe de Apoio ao Figurino: Valdeci Alves da Silva, Fátima de Assis Paula, Genilton Domingos, Ucia Margarida Ribeiro, Marcos André Souza, Marcos Avisk, Nilza Faria, Valdemir Nunes, Vânia da Silva Andrade, Sheila Helená Pedra, Maria lara Gomes Rodrigues, Cacilda Cavalcante de Souza, Durvalina Maria Resende Mendes, Éster do Carmo Carvalho, Maria Bezerra, Maria Dalva dos Santos, Railda Marques Lima, Raimunda Martins Espírito Santo, Raquel de Castro Barbosa, Selma Epifania da Silva, Wanda Pinto Ramos, Laura Maria e Dias da Silva

Direção de Fotografia: José Tadeu e Chico Boya

Direção de Iluminação: Manoel Gomes da Silva

Equipe de Iluminação: Anselmo Silva Marinho, Arnaldino Saior, Ivan Ricardo Muniz da Silva, Jorge Luiz Rodrigues de Brito, José Prates, Marcelo Ribeiro Nunes da Costa, Marco Antonio Costa dos Reis, Renato Pedroso, Sandro Fernandes Garcia, Sidnei Cussa, Márcio Gonçalves, Marcelo da Costa Sara mago Pinheiro e Otávio de Oliveira

Produção de Arte: Yurica Yamasaki e Jussara Xavier

Produtores de Arte Assistentes: Ana Paula Guimarães, Andréia Nakai, Jorge de Tharso

Equipe de Apoio à Arte: Guaracy da Silva Lima, IIbernon Jorge de Faria, Ricardo de Paiva e Rogério Ribeiro Pestana Produção de Elenco Frida Richter

Instrutor de Dramaturgia: Paloma Riani Produção Musical Roger Henri

Direção Musical: Mariozinho Rocha Caracterização Marlene Moura

Equipe de Apoio à Caracterização: Núbia Maisa Silva, Ricardo Sartori, Jaldete Vieira Garcia, Jorge Henrique Monteiro, Gilvana Lemos de Souza, Maria Conceição Santos, Maria de Lourdes Santos da Silva, Marli Afonso de Toledo e Ulian Gomes do Amaral 
Edição: Carlos Roberto Ferreira Mendes (Gordo), Anibal da Piedade Veiga, Paulo Henrique Farias e William Alves Correia Junior

Sonoplastia: Aroldo de Barros Arruda, Francisco Carlos de Souza e Renato Pimentel Muniz

Efeitos Visuais: Capy Ramazzina

Efeitos Especiais: Federico Farfan Abertura Hans Donner

Direção de Imagem: William Garcez Câmeras Lúcio Sibaldi, Murilo Azevedo, Carlos Roberto Erthal Monnerat, Luiz Carlos da Silva Maidana, Maurício Moreira de Azevedo, Afonso Henrique Buriche Coutinho e Edison da Silva Carvalho

Equipe de Apoio à Operção de Câmera: Epitácio Alves do Nascimento, José Jorge Roberto Martins, Jorge Leal, Manoel Tibúrcio de Medeiros Filho e Washington Carneiro Silva

Equipe de Vídeo: João Carlos Morgado de Souza, André Araújo Costa, José Antonio Fernandes Mendes, Murilo Morgado Equipe de Áudio Dilson Nunes Costa, Lourival Santos Neto, Ricardo Knupp, Leonardo da Silva Peçanha

Supervisor e Op. Sistema: Marcelo Cardoso de Almeida, Murilo Morgado, José Antonio Mendes, André Araújo Costa

Gerente de Projetos: Alexandre Gama

Supervisor de Prod. de Cenografia: José Carlos Correa e China

Equipe de Cenotécnica: Ailton Goncalves Moreira, Alexandre Macedo Ramos, A!exsandra Conceicao de Jesus, Cláudio Pereira, Evandro Pimentel Cândido, Glória Maria de Souza, Ivo Cipriano da Silva, José Carlos Aleluia, Marcelo de Oliveira Correa, Marcelo Evangelista de Oliveira, Paulo César Ribeiro da Silva, Petterson Guimarães da Silva, Ricardo Christo Pimentel, Roberto Francisco da Rocha, João Henrique Rondão, Jorge Lopes de Araújo, Luiz Henrique Peixoto, Carlos Henrique G. dos Santos, Francisco de Assis Gomes Barbosa, Iremar Xavier Braz, Ivanildo da Silva, José Norberto dos Santos, André Luis Franca Correa, Darcy Barbosa da Silva Gonçalves, Gilberto Pereira de Lima, Jorge Luiz de Assis Coelho, Jorge Ricardo Paula dos Santos, Valter Silva Santos e Juarez Trindade

Pesquisa: Carmem Righetto

Continuidade: Danielle Bernardes, Mara Cecilia e Maria Cecília Fortuna

Produção de Engenharia: Marco Gesualdi

Equipe de Produção: César Brasil, Fernanda Moreno, Luiz Carlos Magalhães, Nelson Rodrigues, Daniel Ruiz, Carlos Eduardo Bessa, Mônica Costa e Marcílio Thomaz Santana

Coordenador de Produção: João Romita e Marilia Fonseca

Elenco

Adolpho Pasinato

Adriana Garib

Alexandre Akerman

Aline Ribeiro Dantas

Álvaro Freire;

Alvise Camozzi

Amanda Lee (Moema)

Amanda Pinheiro

Ana Bach 
Ana Katarine Steffen

Ana Lúcia Torre (Sálua)

Ana Paula Arósio (Yolanda Penteado)

André Frateschi

André Gasparelli

André Guerreiro

Ângelo Antônio (Madiano Mattei)

Anna Erica Duncan

Anna Marcia Mixo

Antonio Adder

Antonio Calloni (Assis Chateaubriand)

Antonio Carlos Feio

Antonio de Bonis

Ariclê Perez (Madame Claire)

Augusto Gutierrez

Augusto Rolo

Bartholomeu di Haro

Betty Gofman (Anita Malfatti)

Breno Moroni

Bruna de Tullio

Bruno Rocha

Caco Baresi

Caio Junqueira (Nonê)

Camila Morgado (Cacilda Becker)

Carlos Bernardo C. Ferreira

Carlos Marques de Oliveira

Carlas Sato

Carlos Vereza (David Rosemberg)

Carol Nassif

Cássia Kiss (Guiomar Penteado)

Cássio Gabus Mendes (Juvenal Penteado)

Cássio Scapin (Santos Dumont)

Cecília Lage

Celso Frateschi (Ernesto da Silva)

Charles Myara

Chica Xavier (Isolina)

Cláudio Caparica

Cláudio de Andrade

Cláudio Fontana (Jayme Penteado)

Cláudio Gardin

Cláudio Jaborandy

Cristiana Guinle

Daniel de Oliveira (Bernardo Sousa Borba)

Daniela Escobar (Soledad)

Daniele Calmon

Daniella Oliverti

Débora Falabella (Raquel Rosemberg)

Deborah Catalani

Délcio Marinho

Diana Barcellos

Dinho Valladares

Dino Boy

Dira Paes (Magnólia Cavalcanti)

Edgar Muller

Edson Celulari (Francisco 'Ciccillo' Matarazzo)

Eduardo Hollanda

Eduardo Salles

Eduardo Vargas

Edward Boggiss 
Eliane Giardini (Tarsila do Amaral)

Elias Gleiser

Emiliano Queiroz

Eric Nowinski

Érica Oliviero

Erik Marmo (Martim Paes de Almeida)

Etti Fraser

Fábio Cador

Fernanda Gomes

Fernanda Paes Leme (Elisa Furtado)

Fernanda Souza (Dulce do Amaral)

Flávio Araújo

Gabriela Hess (Guiomarita Penteado)

Gagan;

George Vassilatos

Gilberto Marmoros

Gilles Gwizdek

Glória Menezes

Guilherme Correa

Guti Rocha

Helena Ranaldi (Lídia Rosemberg)

Hélio Behring;

Hélio Fonseca

Herson Capri (Fernão Queiroz Chaves)

Igor Adamovich (João Cândido 'Candinho' Souza Borba)

Irving São Paulo (Geraldo Ferraz)

Isabela Cunha (Ursula Schmidt da Silva)

Isio Guelman

Ivan Gradin

Jacy Marques

Jayme dei Curto

José Augusto Branco

José Rubens Chachá (Oswald de Andrade)

Júlia Almeida

Julia Feldens (Maria Laura Souza Borba - adulta)

Júlia Ruiz

Juliana Lohmann

Juliano Righetto (Waldemar Belisário)

Junyor Prata

Larissa Vereza

Leandra Leal (Ursula Schmidt da Silva - adulta)

Leonardo Torloni

Leopoldo Pacheco (Samir)

Letícia Navarro

Letícia Sabatella (Maria Luísa Sousa Borba)

Lu Grimaldi (Frida Schmidt da Silva)

Luca de Castro

Lucas Maia

Luciana Fregolente

Luciano Mallmann

Luiz Damasceno

Luiz Thomaz

Luiza de Oliveira Junqueira

Magda Gomes (Maria José)

Marcello Antony (Rodolfo Souza Borba)

Marcelo Torreão

Marcelo Várzea (Guilherme de Almeida)

Márcia Fialho

Márcio Riciardi 
Marcos Daud

Marcos Nofre

Marcos Pegossi

Marcos Winter (Luís Martins)

Marcus Aníbal

Maria Clara Mattos

Maria Eduarda Manga (Maria Laura Souza Borba)

Maria Fernanda Cândido (Ana Schmidt)

Maria Luísa Mendonça (Maria Bonomi)

Marília Passos

Mateus Solano

Mauro José

Mauro Mendonça

Max Fercondini (João Cândido 'Candinho' Souza Borba - adulto)

Miguel Nader

Mika Lins (Elvira)

Mila Moreira (Lola Flores)

Miriam Freeland (Patrícia 'Pagu' Galvão)

Miwa Yanagizawa

Múcio Medeiros

Murillo Loures

Murilo Grossi

Murilo Rosa (Frederico Schmidt da Silva - adulto)

Nina Moreno (Odila Penteado)

Nizo Netto (Camilo)

Pascoal da Conceição (Mário de Andrade)

Paula Hunter (Gilda Arantes)

Paulo Ascenção

Paulo Bernardo

Paulo Carvalho

Paulo Goulart (Avelino dos Santos)

Paulo Japyassu

Paulo José (Dr. Varela)

Paulo Leão

Pedro Paulo Rangel (Freitas Valle)

Phelippe Louis Bertin Terra Seca

Ranata Saiuri

Rainiere Gonzales (Menotti del Picchia)

Reanta Santos

Renato Scarpin (Joaquim Ferreira dos Santos)

Ricardo Herriot

Ricardo Tostes

Rodrigo Padilha

Rodrigo Penna

Roger da Silva Aires

Rogerio Faria

Roque Paulo Correia

Rui Rezende

Sebastião Lemos

Selma Egrei (Olívia Penteado)

Sergio Gelles

Sergio Mox

Sergio Viotti (Samuel)

Stepan Necerssian

Tamara Ribeiro (Erica Schmidt da Silva)

Tarcísio Meira (Totonho Sousa Borba)

Tato Gabus (Paulo Prado)

Thadeu Torres (Frederico Schmidt da Silva)

Thatiana Pagung 
Theodoro Cochrane (Mário Martins)

Thiago Mesquita

Thiago Oliveira

Toninho Dantas

Tony Correa

Tuna Dwek (Marinete Prado)

Ulisses Cruz

Vicentini Gomes (Graça Aranha)

Vinicius Brambilla

Vinicius Marquez

Vinícius Soares

Viviane Araújo

Viviane Reis

Waldyr Balan

Walter Cândido

Xando Graça

Yoná Magalhães

Zé Luiz Perez 


\section{LISTA DE NOVELAS E MINISSÉRIES PRODUZIDAS PELA REDE GLOBO E AMBIENTADAS EM SÃO PAULO}

Novelas

\begin{tabular}{|c|c|c|c|}
\hline TÍTULO & $\begin{array}{l}\text { DATA DE } \\
\text { PRODUÇÃO } \\
\text { E EXIBIÇÃO }\end{array}$ & AUTOR & $\begin{array}{l}\text { INFORMAÇÕES } \\
\text { ADICIONAIS }\end{array}$ \\
\hline $\begin{array}{l}\text { A Próxima } \\
\text { Atração }\end{array}$ & 1970-1971 & Walter Negrão & $\begin{array}{l}\text { Cidade de São Paulo - Jardim } \\
\text { América }\end{array}$ \\
\hline $\begin{array}{l}\text { Meu Pedacinho } \\
\text { de Chão }\end{array}$ & 1971-1972 & $\begin{array}{l}\text { Benedito Ruy Barbos } \\
\text { e Teixeira Filho }\end{array}$ & $\begin{array}{l}\text { Gravada em duas fazendas do } \\
\text { município de Itu, São Paulo }\end{array}$ \\
\hline $\begin{array}{l}\text { Os Ossos do } \\
\text { Barão }\end{array}$ & 1973-1974 & Jorge de Andrade & São Paulo \\
\hline Escalada & 1975 & Lauro César Muniz & $\begin{array}{l}\text { Rio Pardo, } \mathrm{SP}-1^{\mathrm{a}} \text { fase da } \\
\text { história }\end{array}$ \\
\hline O Grito & 1975 & Jorge de Andrade & $\begin{array}{l}\text { Cidade de São Paulo - } \\
\text { crescimento da cidade }\end{array}$ \\
\hline O Casarão & 1976 & Lauro César Muniz & $\begin{array}{l}\text { Região cafeeira, no norte de São } \\
\text { Paulo }-3 \text { tempos }-1^{a} \text { fase } \\
(1900-1916), 2^{\mathrm{a}} \text { fase }(1926- \\
1936), 3^{\mathrm{a}} \text { fase }(1976)\end{array}$ \\
\hline $\begin{array}{l}\text { O Feijão e o } \\
\text { Sonho }\end{array}$ & 1976 & $\begin{array}{l}\text { Adaptação de } \\
\text { Benedito Ruy } \\
\text { Barbosa do romance } \\
\text { homônimo de } \\
\text { Orígenes Lessa } \\
\end{array}$ & $\begin{array}{l}\text { São Paulo, bairro do Bexiga e } \\
\text { Sorocaba, no interior do estado }\end{array}$ \\
\hline Estúpido Cupido & 1977 & Mário Prata & $\begin{array}{l}\text { Fictícia cidade de Albuquerque, } \\
\text { no interior de São Paulo }\end{array}$ \\
\hline Nina & $1977-1978$ & Walter George Durst & $\begin{array}{l}\text { São Paulo, capital, entre } 1926 \text { e } \\
1929\end{array}$ \\
\hline Plumas e Paetês & $1980-1981$ & $\begin{array}{l}\text { Cassiano Gabus } \\
\text { Mendes, substituído } \\
\text { por Sílvio de Abreu }\end{array}$ & $\begin{array}{l}\text { São Paulo, capital - ambientes e } \\
\text { lugares da moda (padrões da } \\
\text { sociedade de consumo da } \\
\text { época) }\end{array}$ \\
\hline $\begin{array}{l}\text { Ciranda de } \\
\text { pedra }\end{array}$ & 1981 & Teixeira Filho & $\begin{array}{l}\text { Cidade de São Paulo, } 1947 \text { - } \\
\text { pós-guerra }\end{array}$ \\
\hline Jogo da Vida & $1981-1982$ & $\begin{array}{l}\text { Sílvio de Abreu, } \\
\text { inspirada no conto } \\
\text { homônimo de janete } \\
\text { Clair }\end{array}$ & São Paulo, capital \\
\hline $\begin{array}{l}\text { Guerra dos } \\
\text { Sexos }\end{array}$ & 1983-1984 & Sílvio de Abreu & Cidade de São Paulo \\
\hline Vereda Tropical & 1984-1985 & Carlos Lombardi & Cidade de São Paulo \\
\hline
\end{tabular}




\begin{tabular}{|c|c|c|c|}
\hline Ti-Ti-Tii & $1985-1986$ & $\begin{array}{l}\text { Cassiano Gabus } \\
\text { Mendes }\end{array}$ & Cidade de São Paulo \\
\hline Cambalacho & 1986 & Sílvio de Abreu & Cidade de São Paulo \\
\hline Sinhá Moça & 1986 & \begin{tabular}{|l|} 
Benedito Ruy \\
Barbosa, adaptada do \\
romance homônimo \\
de Maria Dezone \\
Pacheco Fernandes
\end{tabular} & $\begin{array}{l}\text { Fictícia cidade de Araruna, no } \\
\text { interior de São Paulo - temas } \\
\text { como abolição e café }\end{array}$ \\
\hline Brega \& Chique & 1987 & $\begin{array}{l}\text { Cassiano Gabus } \\
\text { Mendes }\end{array}$ & Cidade de São Paulo \\
\hline Sassaricando & 1987 & Sílvio de Abreu & Cidade de São Paulo \\
\hline Bebê a Bordo & 1989 & Carlos Lombardi & Cidade de São Paulo \\
\hline Vida Nova & 1988 & $\begin{array}{l}\text { Benedito Ruy } \\
\text { Barbosa }\end{array}$ & $\begin{array}{l}\text { Cidade de São Paulo, década de } \\
1940\end{array}$ \\
\hline $\begin{array}{l}\text { Rainha da } \\
\text { Sucata }\end{array}$ & 1990 & Sílvio de Abreu & Cidade de São Paulo \\
\hline $\begin{array}{l}\text { Meu Bem, Meu } \\
\text { Mal }\end{array}$ & 1990-1991 & $\begin{array}{l}\text { Cassiano Gabus } \\
\text { Mendes }\end{array}$ & Cidade de São Paulo \\
\hline Salomé & 1991 & \begin{tabular}{|l|} 
Sérgio Marques e \\
outros, baseada no \\
romance homônimo \\
de Menotti del \\
Picchia
\end{tabular} & São Paulo, década de 1930 \\
\hline Perigosas Peruas & 1992 & Carlos Lombardi & Cidade de São Paulo \\
\hline Deus nos Acuda & 1992-1993 & Sílvio de Abreu & Cidade de São Paulo \\
\hline Renascer & 1993 & \begin{tabular}{|l} 
Benedito Ruy \\
Barbosa
\end{tabular} & Algumas cenas em São Paulo \\
\hline $\begin{array}{l}\text { O Mapa da } \\
\text { Mina }\end{array}$ & 1993 & $\begin{array}{l}\text { Cassiano Gabus } \\
\text { Mendes }\end{array}$ & \\
\hline Olho no Olho & 1993-1994 & $\begin{array}{l}\text { Antonio Calmon e } \\
\text { colaboradores }\end{array}$ & Cidade de São Paulo \\
\hline $\begin{array}{l}\text { A Próxima } \\
\text { Vítima }\end{array}$ & 1995 & $\begin{array}{l}\text { Sílvio de Abreu com } \\
\text { colaboração de Maria } \\
\text { Adeleide Amaral e } \\
\text { Alcides Nogueira }\end{array}$ & Cidade de São Paulo \\
\hline Cara e Coroa & 1995-1996 & Antonio Calmon & $\begin{array}{l}\text { Apesar de se passar no rio de } \\
\text { Janeiro, teve cena gravada no } \\
\text { Carandirú }\end{array}$ \\
\hline O Rei do Gado & 1996-1997 & \begin{tabular}{|l} 
Benedito Ruy \\
Barbosa e Edilene \\
Barbosa
\end{tabular} & $\begin{array}{l}\text { Vários pólos de produção, entre } \\
\text { eles Ribeirão Preto e Amparo }\end{array}$ \\
\hline $\begin{array}{l}\text { O Amor Está no } \\
\text { Ar }\end{array}$ & 1997 & Alcides Nogueira & \\
\hline Anjo Mau & 1997-1998 & $\begin{array}{l}\text { Maria Adelaide } \\
\text { Amara, com }\end{array}$ & Cidade de São Paulo \\
\hline
\end{tabular}




\begin{tabular}{|c|c|c|c|}
\hline & & $\begin{array}{l}\text { colaboração de Bosco } \\
\text { Brasil, Vicent Villari } \\
\text { e Dejair Cardoso, } \\
\text { supervisão de texto } \\
\text { de Sílvio de Abreu }\end{array}$ & \\
\hline Torre de Babel & 1998-1999 & $\begin{array}{l}\text { Sílvio de Abreu, com } \\
\text { a colaboração de } \\
\text { Bosco Brasil e } \\
\text { Alcides Nogueira }\end{array}$ & Cidade de São Paulo \\
\hline Terra Nostra & 1999-2000 & $\begin{array}{l}\text { Benedito Ruy } \\
\text { Barbosa, com } \\
\text { colaboração de } \\
\text { Edmara Barbosa e } \\
\text { Edilene Barbosa }\end{array}$ & $\begin{array}{l}\text { Interior (fazendas) e cidade de } \\
\text { São Paulo, no início do século } \\
\text { XX }\end{array}$ \\
\hline Vila Madalena & 1999-2000 & $\begin{array}{l}\text { Walter Negrão, com } \\
\text { colaboração de Júlio } \\
\text { Fisher, Paulo } \\
\text { Cursino, thelma } \\
\text { Guedes, Elizabeth } \\
\text { Jhin, ângela Carneiro } \\
\text { e Vinicius Vianna }\end{array}$ & $\begin{array}{l}\text { Cidade de São Paulo, bairro da } \\
\text { Vila Madalena }\end{array}$ \\
\hline $\begin{array}{l}\text { O Cravo e a } \\
\text { Rosa }\end{array}$ & $2000-2001$ & $\begin{array}{l}\text { Walcyr Carrasco, co- } \\
\text { autoria de Mário } \\
\text { Teixeira e } \\
\text { colaboração de Duca } \\
\text { Rachid }\end{array}$ & Cidade de São Paulo, em 1927 \\
\hline A Padroeira & $2001-2002$ & $\begin{array}{l}\text { Walyr Carrasco e } \\
\text { Mário Teixeira, com } \\
\text { colaboração de Duca } \\
\text { Rachid }\end{array}$ & $\begin{array}{l}\text { Cidade de Guaratinguetá, São } \\
\text { Paulo, em } 1717\end{array}$ \\
\hline $\begin{array}{l}\text { As Filhas da } \\
\text { Mãe }\end{array}$ & $2001-2002$ & $\begin{array}{l}\text { Escrita por Sílvio de } \\
\text { Abreu, Alcides } \\
\text { Nogueira e Bosco } \\
\text { Brasil, com } \\
\text { colaboração de } \\
\text { Sandra Louzada } \\
\end{array}$ & Cidade de São Paulo \\
\hline Esperança & $2002-2003$ & $\begin{array}{l}\text { Benedito Ruy } \\
\text { Barbosa, com } \\
\text { colaboração de } \\
\text { Edmara Barbosa e } \\
\text { Edilene Barbosa. A } \\
\text { aprtir do capítulo } \\
\text { 149, Walcyr Carrasco } \\
\text { assumiu a autoria da } \\
\text { novela, substituindo } \\
\text { Benedito }\end{array}$ & $\begin{array}{l}\text { Cidade de São Paulo, década de } \\
1930\end{array}$ \\
\hline
\end{tabular}




\begin{tabular}{|c|c|c|c|}
\hline Cabocla & 2004 & $\begin{array}{l}\text { Benedito Ruy } \\
\text { Barbosa }\end{array}$ & \\
\hline Alma Gêmea & $2005-2006$ & $\begin{array}{l}\text { Walcyr Carrasco com } \\
\text { colaboração de } \\
\text { Thelma Guedes }\end{array}$ & $\begin{array}{l}\text { Décadas de } 20 \text { (início) e } 40 \\
\text { (maior parte da história). } \\
\text { Fictícia cidade de Roseiral, } \\
\text { interior de São Paulo. Nos } \\
\text { primeiros capítulos mostra cena } \\
\text { no Teatro Municipal }\end{array}$ \\
\hline Belíssima & $2005-2006$ & $\begin{array}{l}\text { Sílvio de Abreu, } \\
\text { escrita também por } \\
\text { Sérgio Marques e } \\
\text { Vinícius } \\
\text { Vianna }\end{array}$ & Cidade de São Paulo \\
\hline Sinhá Moça & 2006 & $\begin{array}{l}\text { Benedito Ruy } \\
\text { Barbosa, adaptada } \\
\text { por Edmara Barbosa } \\
\text { e Edilene Barbosa, } \\
\text { baseada no romance } \\
\text { homônimo de Maria } \\
\text { Dezone Pacheco } \\
\text { Fernandes }\end{array}$ & $\begin{array}{l}\text { Final do século XIX, fictícia } \\
\text { cidade de Araruna, São Paulo - } \\
\text { temas como abolição e café }\end{array}$ \\
\hline
\end{tabular}




\section{Minisséries}

\begin{tabular}{|c|c|c|c|}
\hline Avenida Paulista & 1982 & $\begin{array}{l}\text { Escrita por Daniel Más e } \\
\text { Leilah Assumpção, } \\
\text { coordenação de texto de } \\
\text { Luciano Ramos }\end{array}$ & Cidade de São Paulo \\
\hline Fernando Da Gata & 1983 & $\begin{array}{l}\text { Escrita pelo jornalista Ferando } \\
\text { Pacheco Jordão }\end{array}$ & Cidade de São Paulo \\
\hline $\begin{array}{l}\text { Anarquistas Graças a } \\
\text { Deus }\end{array}$ & 1984 & $\begin{array}{l}\text { Adaptação de walter George } \\
\text { Durst do livro de memórias } \\
\text { homônimo de Zélia Gattai }\end{array}$ & $\begin{array}{l}\text { São Paulo, década de } \\
1920\end{array}$ \\
\hline A Máfia no Brasil & 1984 & $\begin{array}{l}\text { Adaptação livre de Leopoldo } \\
\text { Serran do livro homônimo de } \\
\text { Edson Magalhães, roteiro final } \\
\text { de Paulo Afonso Grisolli e } \\
\text { Roberto Farias }\end{array}$ & $\begin{array}{l}\text { Entre outros lugares } \\
\text { teve locações em São } \\
\text { Paulo }\end{array}$ \\
\hline $\begin{array}{l}\text { Memórias de um } \\
\text { Gigolô }\end{array}$ & 1986 & $\begin{array}{l}\text { Adaptação de Marcos Rey e } \\
\text { de Walter George Durst do } \\
\text { livro homônimo de Marcos } \\
\text { Rey. Roteiro final de Walter } \\
\text { Avancini } \\
\end{array}$ & $\begin{array}{l}\text { São Paulo, final da } \\
\text { década de } 1920\end{array}$ \\
\hline Sampa & 1989 & $\begin{array}{l}\text { Escrita por Gian Francesco } \\
\text { Guarnieri }\end{array}$ & $\begin{array}{l}\text { Ambientada em São } \\
\text { Paulo com elenco } \\
\text { predominantemente } \\
\text { paulista }\end{array}$ \\
\hline Boca do Lixo & 1990 & Sílvio de Abreu & \\
\hline A Muralha & 2000 & $\begin{array}{l}\text { Escrita por Maria Adelaide } \\
\text { Amaral e João Emanuel } \\
\text { Carneiro, com colaboração de } \\
\text { Vicent Villari }\end{array}$ & $\begin{array}{l}\text { São Paulo, início do } \\
\text { século XVII }\end{array}$ \\
\hline Um Só Coração & 2004 & $\begin{array}{l}\text { Maria Adelaide Amaral e } \\
\text { Alcides Nogueira. Escrita com } \\
\text { Lúcio Manfredi. Colaboração } \\
\text { de Rodrigo Arantes do Amaral }\end{array}$ & $\begin{array}{l}\text { Cidade de São Paulo, } \\
\text { entre as décadas de } \\
1920 \text { e } 1950 .\end{array}$ \\
\hline
\end{tabular}




\section{ANEXOS}

